UNIVERSITAT POLITÈCNICA DE VALÈNCIA DEPARTAMENTO DE MÁQUINAS Y MOTORES TÉRMICOS
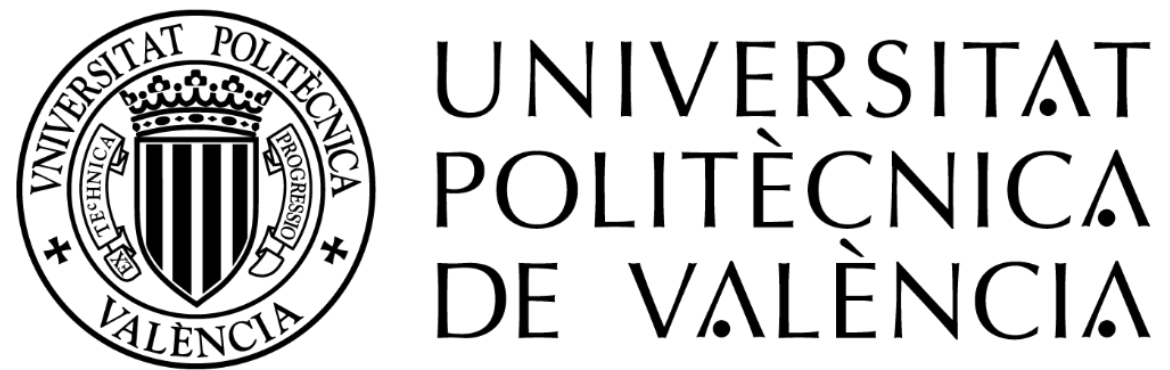

\title{
ANALYSIS OF THE HIGH PRESSURE EGR DISPERSION AMONG CYLINDERS IN AUTOMOTIVE DIESEL ENGINES
}

\author{
DOCTORAL THESIS \\ Presented by: \\ Mr. Julián Miguel García \\ Directed by: \\ Dr. Héctor Climent Puchades
}

València, December 2020 

DOCTORAL THESIS

AnAlysis of THE High Pressure EGR DisPersion AMONG CYLINDERS IN Automotive Diesel ENGINES

Presented by: Mr. Julián Miguel García

Directed by: Dr. Héctor Climent Puchades

Thesis examiners

Dr. Alain Maiboom

Dr. M. Arántzazu Gómez Esteban

Dr. Richard David Burke

Defence committee

President: Dr. José Ramón Serrano Cruz

Secretary: Dr. Francisco Vera García

Vocal: $\quad$ Dr. Alain Maiboom

València, December 2020 



\section{ANAlysis of THE High Pressure EGR \\ DISPERSION AMONG CYLINDERS IN}

Automotive Diesel ENGINES

Julián Miguel García 



\section{Abstract}

The objective of the study is twofold. On the one hand, it is to determine the effect of the high pressure (HP) exhaust gas recirculation (EGR) dispersion in automotive diesel engines on NOx and smoke emissions in steady engine operation. The investigation quantifies the smoke emissions as a function of the dispersion of the HP EGR among cylinders. On the other hand, it is to explore the limits of the one-dimensional (1D) modeling to predict the movement of the flow in a complex situation as the gases get into the cylinders from the intake manifold.

The experiments are performed on a test bench with a 1.6 liter automotive diesel engine. In order to track the HP EGR dispersion in the intake pipes, a valves system to measure $\mathrm{CO}_{2}$, hence EGR rate, pipe to pipe was installed. In the same way, a valves device to measure NOx emissions cylinder to cylinder in the exhaust was installed too. Moreover, a smoke meter device was installed in the exhaust line, downstream the turbine, to measure the effect of the HP EGR dispersion on smoke emissions. A probe to measure the other raw emissions was installed downstream the turbine, too. Nine different engine running conditions were studied at different speed and load, thus the engine map was widely studied, from $1250 \mathrm{rpm}$ to $3000 \mathrm{rpm}$ and between 3 and 20 bar of BMEP. The EGR rate variates between 5 and $42 \%$ depending on the working operation point. The geometry of the model reproduces the geometry of a 1.6 liter diesel automotive engine where the tests were performed. It includes an HP-EGR line and the device that was installed to perform the experiments to control the dispersion.

The methodology focused on experimental tools combining traditional measuring devices with a specific valves system which offers accurate information about species concentration in both the intake and the exhaust manifolds. The study was performed at constant raw NOx emissions to observe the effect of the EGR dispersion in the opacity values. Regarding the methodology focused on modeling tools, the boundary conditions and all the necessary information to run the model comes from experimental results measured with the different sensors and devices mentioned before. Much of them were needed to adjust the model. The most important part of the modeling 
to study the capacity of the prediction of the EGR dispersion is the layout of the intake manifold. It is necessary put special attention to the orientation of the pipes, and the internal structure and surface trying to mimic the real geometry because it determinates the prediction of the dispersion. This approximation to quasi-three-dimensional (3D) modeling is possible thanks to a specific software that imports the necessary information from a computer-aided design (CAD) file to the 1D modeling software.

Concerning the experimental results, the study leads to conclude that when the EGR dispersion is low, the opacity presents reduced values in all operation points. However, above a certain level of EGR dispersion, the opacity increases dramatically with different slopes depending on the engine running condition. This study allows quantifying this EGR dispersion threshold. In addition, the EGR dispersion could contribute to an increase in the engine fuel consumption up to $6.9 \%$. Regarding to the modeling part, the study concludes that when the experimental EGR distribution among pipes is asymmetric and presents high concavity or convexity spatial pattern, the model does not predict properly the EGR distribution. In addition, the study concludes that, although in the experimental tests the EGR rate affects to the EGR dispersion, the 1D model is not too sensitive to predict this influence when the EGR rate is lower than $10 \%$. 


\section{Résumé}

L'objectif de cette étude est double. D'un côté, déterminer l'effet de la dispersion à haute pression (HP pour ses sigles en anglais) de la recirculation des gaz d'échappement (EGR pour ses sigles en anglais) sur les oxydes d'azote (NOx) et les émissions de fumée durant le fonctionnement stable du moteur. La recherche quantifie les émissions des fumées en fonction de la dispersion des EGR à HP dans les cylindres. De l'autre côté, explorer les limites des modèles unidimensionnels (1D) pour faire des prédictions sur le mouvement de l'écoulement dans une situation complexe : les gaz pénétrant dans les cylindres depuis le collecteur d'admission.

Les expériences sont réalisées dans un banc d'essai avec un moteur diesel automobile de 1.6 litres. Pour suivre la dispersion des EGR à HP dans les collecteurs d'admission, un système de vannes a été installé sur chaque tuyau. Cela permet de mesurer le $\mathrm{CO}_{2}$ et, pourtant, le débit d'EGR. Un système de vannes pour mesurer les émissions de NOx dans chaque cylindre a été installé aussi. En plus, un dispositif de compteur de fumée est placé dans le pot d'échappement, en aval la turbine. Son but est le mesurément de l'effet de la dispersion des EGR à HP sur les émissions de fumées. Un capteur a été installé après la turbine pour mesurer les autres émissions. Neuf conditions de fonctionnement du moteur ont été étudiées à différentes vitesses et charges moteur. Par conséquent, la cartographie moteur a été étudiée en profondeur : de 1250 à 3000 rpm et 3 à 20 bar BMEP (pression moyenne effective de frein). Le débit EGR oscille entre $5 \%$ et $42 \%$ selon le point d'opération. La géométrie du modèle reproduit celle du moteur 1.6 litres sur lequel les tests ont été effectués. Elle inclut une ligne EGR-HP et le dispositif installé pour réaliser les expériences pour contrôler la dispersion.

La méthodologie s'est concentrée sur des outils expérimentaux et elle combine les dispositifs traditionnels de mesurément avec un système de vannes spécifique qui offre des données précises sur la concentration des particules dans les collecteurs d'admission et d'échappement. L'étude a été réalisé avec des émissions constantes d'oxydes d'azote pour observer l'effet de la dispersion des EGR sur les valeurs d'opacité. En ce qui concerne la méthodologie des outils de modélisation, les valeurs en limites et toute l'information nécessaire pour le 
modèle viennent des résultats des expériences, mesurés avec les capteurs et dispositifs mentionnés précédemment. Plusieurs étaient nécessaires pour ajuster le modèle. La part la plus importante de ce modèle pour étudier la capacité de prédiction de la dispersion EGR est la disposition du collecteur d'admission. Il faut porter une attention particulière à l'orientation des tuyaux, à la structure interne et à la surface en essayant d'être très fidèle à la géométrie réelle car elle détermine la prédiction de la dispersion. Cette approximation à la modélisation quasi-trois-dimensionnel (3D) est possible grâce à un logiciel spécifique qui obtient l'information d'un fichier de conception assistée par ordinateur (CAD pour son acronyme en anglais) et la transforme pour le logiciel de modélisation 1D.

Concernant les résultats des expériences, l'étude permet de conclure que l'opacité présente des valeurs réduites dans tous les points d'opération si la dispersion EGR est baisse. Néanmoins, au-dessus d'un certain niveau de dispersion EGR, l'opacité incrémente de façon dramatique avec des pentes qui dépendent de l'état de fonctionnement du moteur. Cette recherche permet la quantification de ce seuil de dispersion EGR. En plus, la dispersion EGR pourrait contribuer à l'augmentation de la consommation de carburant (jusqu'à $6.9 \%$ ). En ce qui concerne la modélisation, l'étude conclut que le modèle ne prédite pas correctement la distribution EGR si la distribution des EGR expérimentaux parmi les tuyaux est asymétrique et présente une concavité haute ou une structure spatiale. Aditionellement, l'étude conclut que, même si le débit EGR a une influence sur la dispersion RGE pendant les expériences, le modèle 1D n'est pas assez sensible pour prédire cette influence quand le débit EGR est inférieur au $10 \%$. 


\section{Resum}

L'objectiu de l'estudi és doble. Per una banda, determinar l'efecte de la dispersió de la recirculació de gasos d'escapament d'alta pressió (HP EGR per les seues sigles en anglès) en les emissions d'òxids de nitrogen (NOx) i fums en motors dièsel d'automoció en operacions de funcionament constants. La investigació quantifica les emissions de NOx i fums en funció del nivell de dispersió d'EGR d'alta pressió entre cilindres. Per una altra banda, l'objectiu és explorar els límits del modelatge unidimensional (1D) per predir el moviment del flux dels gasos en la complexa situació en què aquests entren als cilindres des del col-lector d'admissió.

Els experiments van ser realitzats en un banc de proves amb un motor dièsel de 1.6 litres. Per detectar la dispersió d'EGR d'alta pressió es va instal·lar un sistema de vàlvules en els conductes d'admissió de cada cilindre per mesurar el percentatge de $\mathrm{CO}_{2}$ i per tant la taxa d'EGR. De la mateixa manera es va instal-lar també un sistema de vàlvules d'escapament, cilindre a cilindre, per mesurar les emissions de NOx. A més també es va instal-lar un sensor de fums en la línia d'escapament, aigües avall de la turbina, per mesurar l'efecte de la dispersió d'EGR d'alta pressió en les emissions de fums, així com el sensor de mesura de la resta d'emissions aigües avall de la turbina. S'han estudiat 9 punts de funcionament diferents amb distintes velocitats i nivells de càrrega, per la qual cosa el mapa motor s'ha estudiat en profunditat, des de 1250 fins a 3000 rpm i entre 3 i 20 bar de pressió mitjana efectiva (BMEP per les seues sigles en anglès). La taxa d'EGR varia entre 5 i $42 \%$, depenent del punt de funcionament. La geometria del model reprodueix la geometria del motor dièsel d'automoció d'1.6 litres en el qual es van realitzar tots els assajos experimentals.

La metodologia centrada en les ferramentes experimentals combina aparells de mesura tradicional amb un sistema de vàlvules específic que ofereixen una informació precisa quant a la concentració d'espècies tant al col-lector d'admissió com al d'escapament. L'estudi es va realitzar a emissions de NOx constants per observar l'efecte de la dispersió d'EGR en els valors d'opacitat. Quant a la metodologia centrada en les ferramentes de modelatge, les condicions de contorn i tota la informació necessària per posar en marxa el model prové dels resultats dels assajos experimentals mesurats amb els 
diferents sensors i aparells mencionats anteriorment, molts d'ells necessaris per ajustar el model. La part més important per estudiar la capacitat de predicció del model és el disseny del collector d'admissió. És necessari posar especial atenció a l'orientació dels conductes, i a l'estructura interna i la superfície per tractar de ser molt fidel a la geometria real, ja que determina la predicció de la dispersió. Esta aproximació del model quasi-tridimensional (3D) és possible gràcies a un programa específic que importa la informació necessària des d'un arxiu de disseny assistit per ordinador (CAD per les seues sigles en anglés) al programa de modelat 1D.

Respecte a la part experimental, l'estudi conclou que quan la dispersió d'EGR és baixa, els nivells d'opacitat es redueixen en tots els punts de funcionament. Tanmateix, per damunt de certs nivells de dispersió d'EGR, l'opacitat creix seriosament amb diferents pendents segons el punt d'operació. L'estudi permet quantificar aquest límit de dispersió d'EGR. A més, la dispersió d’EGR podria contribuir a incrementar el consum de combustible per damunt del $6.9 \%$. Respecte a la part de modelatge, l'estudi conclou que quan la distribució d'EGR entre conductes mesurada experimentalment és asimètrica i presenta un alt patró de concavitat o convexitat, el model no prediu adequadament la distribució d'EGR. A més, l'estudi conclou que, tot i que en els assajos experimentals la taxa d'EGR afecta a la dispersió d'EGR, el model 1D no és tan sensible com per predir aquesta influència quan la taxa d'EGR està per baix del $10 \%$. 


\section{Resumen}

El objetivo del estudio es doble. Por un lado, determinar el efecto de la dispersión de la recirculación de gases de escape de alta presión (HP EGR por sus siglas en inglés) en las emisiones de óxidos de nitrógeno (NOx) y humos en motores diésel de automoción en operaciones de funcionamiento constantes. La investigación cuantifica las emisiones de NOx y humos en función del nivel de dispersión de EGR de alta presión entre cilindros. Por otro lado, el objetivo es explorar los límites del modelado unidimensional (1D) para predecir el movimiento del flujo de los gases en la compleja situación en la que estos entran en los cilindros desde el colector de admisión.

Los experimentos fueron realizados en un banco de pruebas con un motor diésel de 1.6 litros. Para detectar la dispersión de EGR de alta presión se instaló un sistema de válvulas en los conductos de admisión de cada cilindro para medir la concentración de $\mathrm{CO}_{2}$ y por lo tanto la tasa de EGR en cada conducto. De la misma manera se instaló también un sistema de válvulas en el escape para medir las emisiones de NOx en cada cilindro. Además también se instaló un sensor de humos en la línea de escape, aguas abajo de la turbina, para medir el efecto de la dispersión de EGR de alta presión en las emisiones de humos además del sensor para medir el resto de las emisiones contaminantes también aguas debajo de la turbina. Se han estudiado 9 puntos de funcionamiento diferentes con distintas velocidades y niveles de carga, así que el mapa motor se ha estudiado en profundidad, desde 1250 hasta 3000 rpm y entre 3 y 20 bar de presión media efectiva (BMEP por sus siglas en inglés). La tasa de EGR varía entre 5 y $42 \%$, dependiendo del punto de funcionamiento. La geometría del modelo reproduce la geometría del motor diésel de automoción de 1.6 litros en el que se realizaron los ensayos experimentales. Incluyendo la línea de EGR de alta presión que fue instalada para controlar los niveles de dispersión durante los ensayos experimentales.

La metodología centrada en las herramientas experimentales combina aparatos de medida tradicional con un sistema de válvulas específico que ofrecen una información precisa en cuanto a la concentración de especies tanto en el colector de admisión como en el de escape. El estudio se realizó a emisiones de NOx constantes para observar el efecto de la dispersión de EGR en los valores de 
opacidad. En cuanto a la metodología centrada en las herramientas de modelado, las condiciones de contorno y toda la información necesaria para poner en marcha el modelo proviene de los resultados de los ensayos experimentales medidos con los diferentes sensores y aparatos mencionados anteriormente. Muchos de ellos necesarios para ajustar el modelo. La parte más importante para estudiar la capacidad de predicción del modelo es el diseño del colector de admisión. Es necesario poner especial atención en la orientación de los conductos, y en la estructura interna y la superficie para tratar de ser muy fiel a la geometría real, ya que ello determina la predicción de la dispersión. Esta aproximación de modelado cuasi tridimensional (3D) es posible gracias a un programa específico que importa la información necesaria desde un archivo de diseño asistido por ordenador (CAD por sus siglas en inglés) al programa de modelado 1D.

Respecto a la parte experimental, el estudio concluye que cuando la dispersión de EGR es baja, los niveles de opacidad se reducen en todos los puntos de funcionamiento. Sin embargo, por encima de ciertos niveles de dispersión de EGR, la opacidad crece seriamente con diferentes pendientes según el punto de operación. El estudio permite cuantificar este límite de dispersión de EGR. Además, la dispersión de EGR podría contribuir a incrementar el consumo de combustible por encima del $6.9 \%$. Respecto a la parte de modelado, el estudio concluye que cuando la distribución de EGR entre conductos medida experimentalmente es asimétrica y presenta un alto patrón de concavidad o convexidad, el modelo no predice adecuadamente la distribución del EGR. Además, el estudio concluye que, aunque en los ensayos experimentales la tasa de EGR afecta a la dispersión de EGR, el modelo 1D no es tan sensible como para predecir esta influencia cuando la tasa de EGR está por debajo del 10\%. 


\section{List of publications}

The present document is based on the following publications:

[1] V. Macián, J. M. Luján, H. Climent, J. Miguel-García, S. Guilain, and R. Boubennec. "Cylinder to cylinder high-pressure exhaust gas recirculation dispersion effect on opacity and NOx emissions in a diesel automotive engine". International Journal of Engine Research (2020), https://doi.org/10.1177/1468087419895401.

[2] J. Galindo, H. Climent, R. Navarro, J. Miguel-García, D. Chalet, and P-E Pretot. "A study on the high pressure EGR transport and application to the dispersion among cylinders in automotive engines". International Journal of Engine Research (2020), https://doi.org/10.1177/1468087420969263. 



\section{Division of work among co-authors}

The work prior to this thesis was done in collaboration with other researches and workers. Who writes this words is the co-author of all publications of this thesis is based, where the authors signatures being in order of seniority in the case of co-authors from CMT-Motores Térmicos department and degree of involvement in the case of co-authors from other institution. The respondent performed the experimental test and measurements including the fabrication and the machining of pieces and the experimental set up; all of this with the guide, help and collaboration of workers whose work is gratefully acknowledged. The 1D model was developed by the respondent too under supervision of the co-author Pierre-Emmanuel Pretot and the supervisor, Prof. Climent. Finally the methodology and results discussion were performed in collaboration with the supervisor, Prof. Climent, just as the rest of co-authors.

\section{Other publications}

The respondent was involved in the following publication but it is not included in this work:

[3] J. M. Luján, H. Climent, F. Arnau, and J. Miguel-García. "Analysis of low pressure exhaust gases recirculation control in transient operation of automotive diesel engines". Applied Thermal Engineering 137 (2018), pp. 184192. https://doi.org/10.1016/j.applthermaleng.2018.03.085.

\section{Funding acknowledgements}

The respondent wishes to acknowledge the financial support received by contract FPI 2015 S2 3101 of Programa de Apoyo a la Investigación y Desarrollo (PAID) from Universitat Politècnica de València (UPV). 



\section{Acknowledgments}

The last five years have been hard, convulses and, sometimes, confusing. A lot of people have crossed my life during this time. It is difficult remembering everybody, it is more than probably that I am not able to mention everyone who deserves it, but I am going to try it.

First of all, my most honest acknowledgment to Professor Héctor Climent Puchades, director and driving of the present work. I have learned a lot during this period thanks to his patience, calm and his attitude to teach. Moreover, not only as professional, but as person, he instills the importance of the progress of the Science to the Society and the Humanity. It is sure that he has been the best director and teacher that I could have had and I am very grateful because of that.

Secondly I want to thank the support and the assistance of the administration stuff and the students that have been collaborated with me in projects. Especially to Amparo Cutillas, who always is watchful about our bureaucratic needs, and Javi Cañón, the best workmate that I could have ever had. Special thanks to the cleaning staff too, they do a work that is invisible most of times, but it is very valuable and fundamental.

It is very important to me express very especial thanks to the technicians. The people who teach me a lot about engines, but not only. A very affective and friendly thanks to Juanan, the person who teach me the most of experimental work. He has had a lot of patience to teach me everything that I have learned from him. Without him, this work would not have been possible. Thanks to Sergio, Vicentón, Toni, Marron, José (the turner), Miguelón and Valentín to teach me and allow me to work with them. I take a pleasant experience from them.

I would like to thank my office workmates and friends: Ausias, Auñón, Artem, Manu Hernandez, Tarí, Pablo, Alberto, Magui, Enrique, Javi Gómez, Chai, Fran, Manu Rivas and Abdel. Their companionship and friendship have done this travel much more pleasant. I have got a great friendship from many of them. I hope they also get it from me. 
I would like to thank my debate friends, too: First of all and very special to Joan, the best right hand that anyone could wish for in the good times and the hard times. Of course also Raúl, Paula, Miquel, Amparo, Andrea, Zulema, Antonio, Álvaro, Ribó, Mercè, Miragall, Anna, Joan Reina and many others. Companionship, friendship, and eternal discussions define mi relationship with them. All of them do very special this period of my life.

Also, I must mention in this section to my fellow activist of València: Lola, Isidoro, Feli, Maite, Fernando "vasco", Fernando "vegano", Sandra, Carla, Kepa, Ferrán, Ana, Fernando, Alex, León, Marcos, Abraham, Jaime and many others. Hours of work, but also talks and beers made me very happy. My time as $\mathrm{PhD}$ student would have been very different without all of them.

During my internship in Nantes, I met people who I must to mention here too. Of course, special thanks to Professor David Chalet and Pierre Emmanuel Prétot who assist me in my work there. Also Clémence, Julien, Esther, Franco and Jonas, friends that I will not forget.

It is mandatory to thank my roommates: Pablo, Inma, Andrés and Raúl again, they suffered, together with me, the inclemency of the PhD student live. They were my support in hard times and shared with me the good ones too.

I also need to thanks my group of friends from Teruel. They have accompanied me since years before this travel: Javi, Jorge, Rubén, Álvaro, Laura, María, Sergi, Marta, Dalila, Rebeca, Lara, Garban and many others. They always brought me happiness and good times.

Along these years I met new people who have become an essential part of my life. They suffered the progression of this work closely. They are Loidi, Lorena and Emi.

Of course I have to thank my closest fellow activists and best friends, my other family: Héctor, Irene, Pablo, David, Julia, Ramón, Saval, Rodrigo, Miguel, Adrián and many others. Many talks, debates, work, travels, experiences and parties have made me learn and grow up together with them. I feel much loved by them and I love them too. 
If anyone deserves a solo paragraph, she is Gala. The person who has accompanied me most closely in this travel. In the best and in the worst moments. I am very grateful to have shared this time with her and the one that lies ahead. Thank you Gala, I am better now than before I meet you.

Finally, very especial thanks to my family, they have been with me unconditionally. I love them and I am sure that I will never be able to give them back what they have given me. I would like to make a special mention to my grandmother, Micaela, who passed away during this period of my life. This is dedicated to her memory.

València, 2020 



\section{Agradecimientos}

Los últimos 5 años han sido duros, convulsos y, a veces, confusos. Mucha gente se ha cruzado en mi vida durante este periodo. Es difícil recordar a todo el mundo y es más que probable que no sea capaz de mencionar a todo aquel o aquella que lo merece, pero voy a intentarlo.

En primer lugar mi más sincero agradecimiento al Catedrático Héctor Climent Puchades, director y guía de este trabajo. He aprendido mucho durante este tiempo gracias a su paciencia, calma y su actitud pedagógica. No solamente como profesional, sino como persona, ya que inculca la importancia del progreso de la Ciencia en la Sociedad y en la Humanidad. Ha sido el mejor director y profesor que podría haber tenido y estoy muy agradecido por ello.

En segundo lugar quiero agradecer el apoyo y la ayuda del personal de administración y los estudiantes que han colaborado conmigo en diferentes proyectos. Especialmente a Amparo Cutillas, que siempre está pendiente de la burocracia, y a Javi Cañón, el mejor compañero de trabajo que podría haber tenido. Un especial agradecimiento también al personal de limpieza, ellas hacen un trabajo que muchas veces pasa desapercibido, pero que es muy valioso y fundamental.

Es para mí especialmente importante expresar mi profundo agradecimiento a los técnicos. Ellos me han enseñado casi todo lo que sé sobre motores, aunque no solamente eso. Me gustaría dedicar un afectuoso agradecimiento a Juanan, la persona que me ha enseñado casi todo lo que tiene que ver con el trabajo experimental y que ha tenido muchísima paciencia para enseñarme todo lo que he aprendido de él. Sin él, este trabajo no habría sido posible. Gracias también a Sergio, Vicentón, Toni, Marron, José (el tornero), Miguelón y Valentín por enseñarme y permitirme trabajar con ellos. Ha sido una gran experiencia.

Quiero dar las gracias también a mis compañeros de despacho y amigos: Ausias, Auñón, Artem, Manu Hernández, Tarí, Pablo, Alberto, Magui, Enrique, Javi Gómez, Chai, Fran, Manu Rivas y Abdel. Me llevo una gran amistad de muchos de ellos. Espero que ellos también de mí.

Me gustaría dar las gracias a mis amigos de debate también: En primer lugar y muy especialmente a Joan, la mejor mano derecha que cualquiera podría desear 
en los mejores y peores momentos. Por supuesto también a Raúl, Paula, Miquel, Amparo, Andrea, Zulema, Antonio, Álvaro, Ribó, Mercè, Miragall, Anna, Joan Reina y muchos otros y otras. Compañerismo, Amistad y eternas discusiones definen mi relación con ellos y ellas. Han hecho muy especial este periodo de mi vida.

También he de mencionar aquí a mis compañeros y compañeras de activismo en València: Lola, Isidoro, Feli, Maite, Fernando "vasco", Fernando "vegano", Sandra, Carla, Kepa, Ferrán, Ana, Fernando, Alex, León, Marcos, Abraham, Jaime y muchos otros y otras. Horas de trabajo, pero también charlas y cervezas me hicieron muy feliz. Mi periodo como estudiante de doctorado habría sido muy diferente sin ellos y ellas.

Durante mi estancia en Nantes conocí a gente que he de mencionar también. Por supuesto merecen un especial agradecimiento el Catedrático David Chalet y Pierre-Emmanuel Prétot que me ayudaron en mi trabajo allí. También a Clémence, Julien, Esther, Franco y Jonas, amistades que no olvidaré.

Tengo que dar las gracias también a mis compañeros y compañera de piso: Pablo, Inma, Andrés y Raúl (otra vez). Ellos y ella han sufrido, junto conmigo, las inclemencias de la vida del estudiante de doctorado. Han sido un apoyo en los momentos duros y han compartido conmigo también los buenos.

He de dar las gracias a mi grupo de amigos de Teruel. Ellos y ellas me han acompañado años antes de empezar este viaje: Javi, Jorge, Rubén, Álvaro, Laura, María, Sergi, Marta, Dalila, Rebeca, Lara, Garban y algunos más. Ellos y ellas me han dado felicidad y buenos ratos.

A lo largo de estos años he conocido gente nueva que se ha convertido en una parte esencial de mi vida. Han sufrido el avance de este trabajo de cerca. Son Loidi, Lorena y Emi.

Por supuesto he de dar las gracias a mis más cercanos compañeros y compañeras de activismo, mi otra familia: Héctor, Irene, Pablo, David, Julia, Ramón, Saval, Rodrigo, Miguel, Adrián y algunos más. Muchas charlas, debates, trabajo, viajes, experiencias y fiestas me han hecho aprender y madurar junto a ellos y ellas. Me siento muy querido por ellos y ellas y yo también les quiero. 
Si alguien merece un único párrafo, esa es Gala. La persona que me ha acompañado más de cerca en este viaje. En los mejores y en los peores momentos. Estoy muy agradecido por haber compartido este tiempo con ella y los que están por llegar. Gracias Gala, ahora soy mejor que cuando te conocí.

Finalmente, un muy especial agradecimiento a mi familia, que han estado a mi lado de manera incondicional. Les quiero y estoy seguro de que nunca seré capaz de devolverles todo lo que me han dado. Me gustaría hacer una especial mención a mi abuela, Micaela, que falleció durante este periodo de mi vida. Este trabajo está dedicado a su memoria.

València, 2020 

"Life should not be lived without commitment"

Rita Levi-Montalcini 



\section{Table of Contents}

1. Objectives and methodology ….................................................................... 1

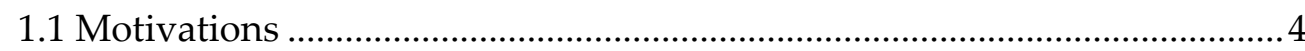

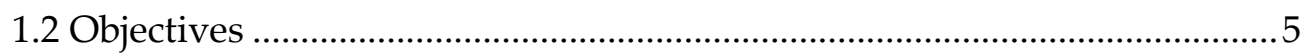

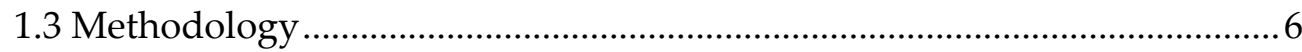

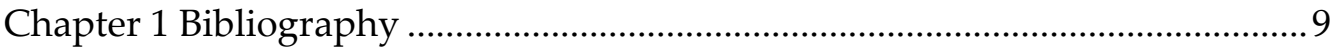

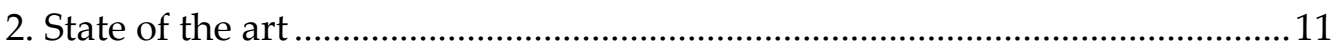

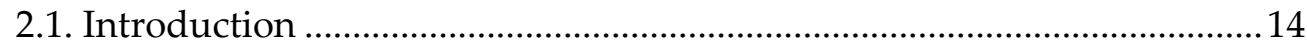

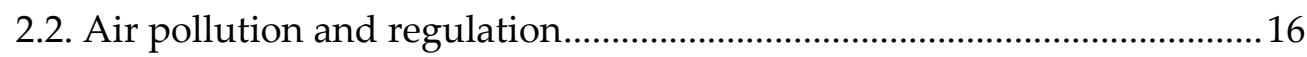

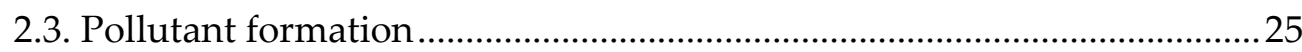

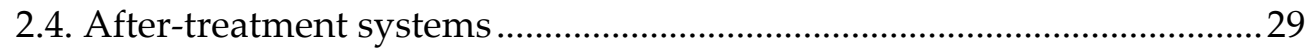

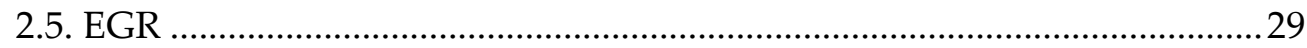

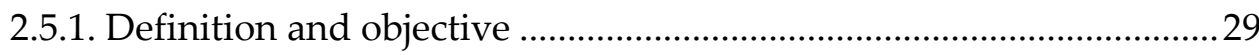

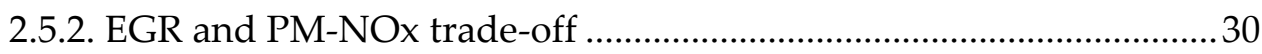

2.5.3. Strategies (HP EGR and LP EGR) ………………………………....... 31

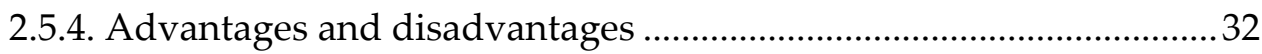

2.5.5. New standards: Low temperatures and transient cycles .................. 32

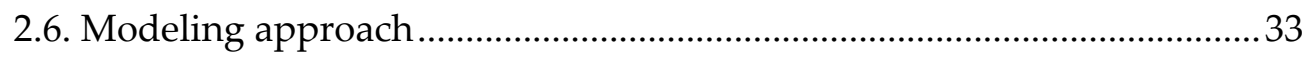

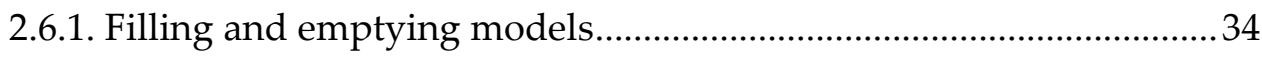

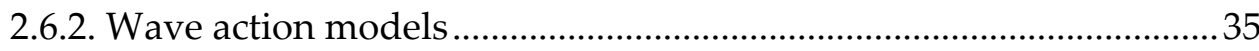

2.6.2.1. Method of the Characteristics ............................................................35

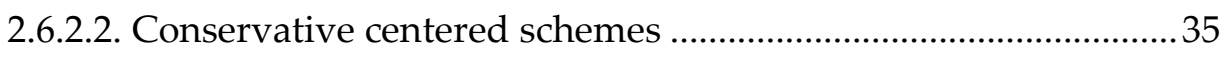

2.6.2.3. Upwind schemes and Riemann solvers ........................................36

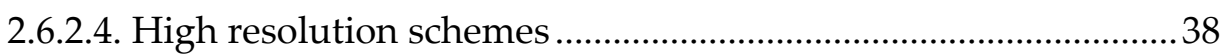

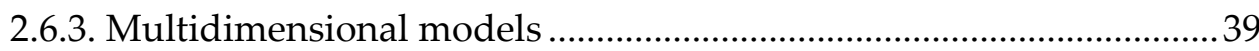




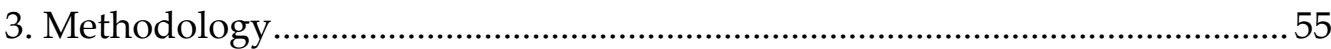

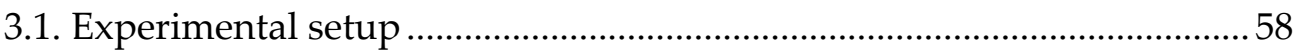

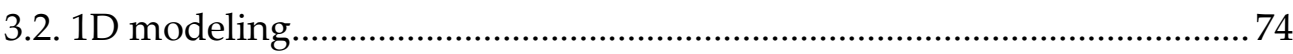

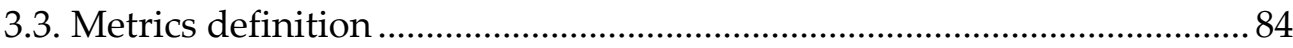

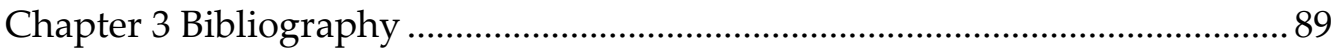

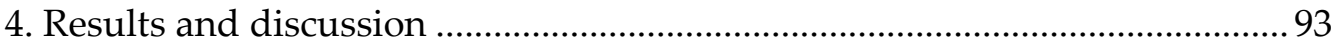

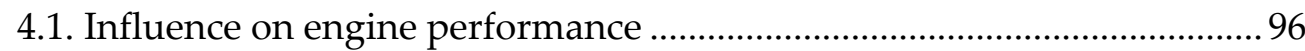

4.1.1. Determination of the reasonable EGR dispersion levels ...................96

4.1.2. Assessment of constant input values .................................................. 101

4.1.3. Influence on opacity of exhaust gases ................................................. 108

4.1.4. Influence on fuel consumption.......................................................... 121

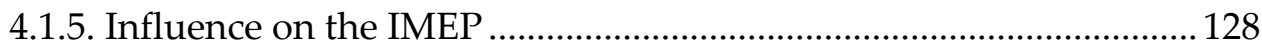

4.1.6. Influence on the exhaust gases composition ..................................... 130

4.1.7. Dimensionless opacity .......................................................................... 133

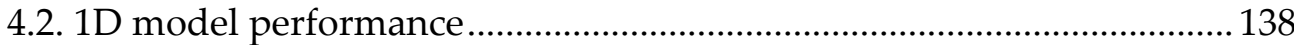

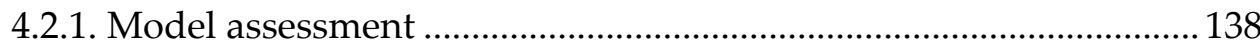

4.2.2. Influence of the manifold layout modeling ....................................... 143

4.2.3. Influence of wave dynamics ............................................................... 145

4.2.4. Influence of the size of the manifold .................................................. 153

4.2.5. Results with controlled EGR dispersion .......................................... 156

4.2.6. Model sensitivity to EGR rate variations ......................................... 163

4.2.7. 1D engine model performance ............................................................. 168 
Chapter 4 Bibliography

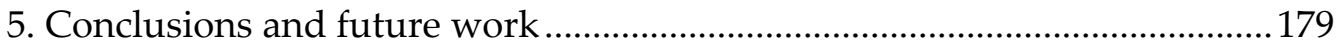

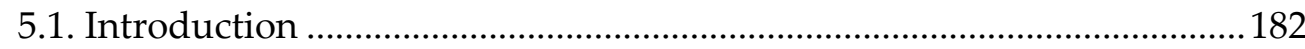

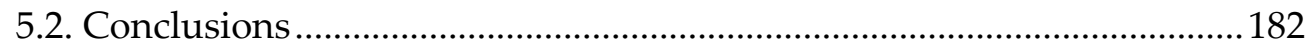

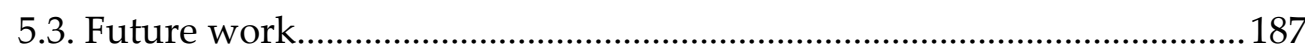

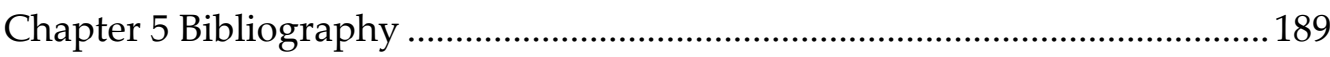

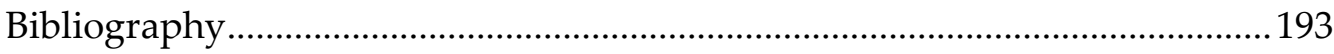





\section{Index of Figures}

2.1. PM vs. NOx emissions, both of them in $\mathrm{g} / \mathrm{km}$, at the different European emissions standards from Euro 1 to Euro 6......................................................... 23

2.2. Constant data in each cell in a Godunov's scheme ........................................37

3.1. The eight probes installed in the intake to measure the gas composition in

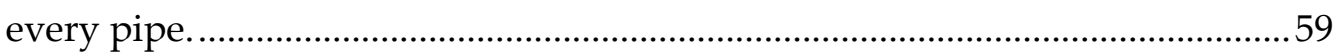

3.2. The six fast $\mathrm{CO}_{2}$ tracking probes installed in the intake..............................61

3.3. Detail of the final assembly in the intake manifold......................................61

3.4. Detail of the sampling pipes in the intake runners. ....................................62

3.5. Detail of the fast tracking $\mathrm{CO}_{2}$ probes location. ............................................ 63

3.6. Rail and valves for intake gas measurement selection. .................................64

3.7. Four probes installed in the exhaust to measure the gas composition in

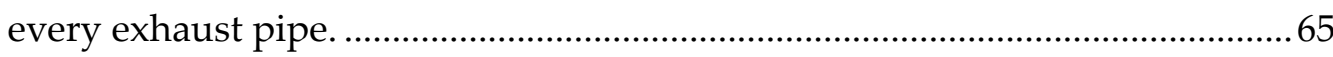

3.8. Rail and valves for exhaust gas measurement selection................................65

3.9. Devices that introduce and mix the EGR with the intake air in the manifold. .66

3.10. Manufacturing device with three regulation valves to control de HP EGR

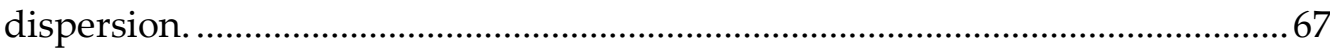

3.11. Intake manifold representation with the six locations for the fast $\mathrm{CO}_{2}$

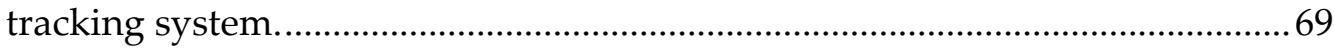

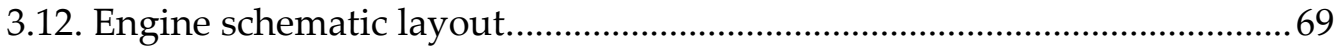

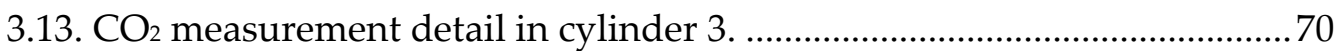

3.14. Division of the intake manifold CAD file in volumes and pipes to the

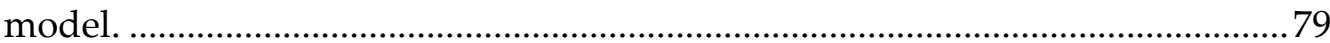

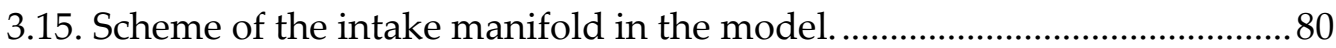

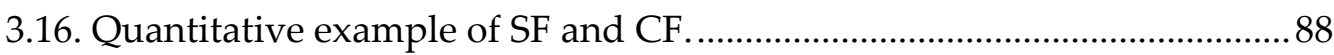

4.1. Engine map. X-axis represents the engine speed, $\mathrm{Y}$-axis represents the engine torque and color bar represents the EGR rate. ......................................97 
4.2. EGR rate intake pipes values vs. pipes at 1500-01, 1500-03, 2500-10 and 250019 from left to right and from top to bottom, all of them performed with mixer 1 . 98

4.3. EGR rate intake pipes vs. pipes at 1500-01, 1500-03, 2500-10 and 2500-19 from left to right and from top to bottom, all of them performed with mixer 2.

4.4. EGR rate intake pipes vs. pipes at 1500-01, 1500-03, 2500-10 and 2500-19 from left to right and from top to bottom, all of them performed with mixer 3 . 100

4.5. Coefficient of variance of the EGR rate among cylinders vs mixers at 150001, 1500-03, 2500-10 and 2500-19. 101

4.6. Intake manifold pressure (left) and engine torque (right) both of them referenced to the nominal value and vs EGR standard deviation at 1250, 1500, 2000, 2500 and $3000 \mathrm{rpm}$ engine conditions (from top to bottom). 104

4.7. Cylinder and engine NOx values vs. EGR rate (left), and engine raw NOx vs. EGR standard deviation (right) for the 1250, 1500, 2000, 2500 and $3000 \mathrm{rpm}$ operation points (from top to bottom). 108

4.8. Opacity vs. EGR standard deviation for the 1250, 1500, 2000, 2500 and 3000 rpm operation points (from left to right and from top to bottom). 110

4.9. $\mathrm{CO}_{2}$ Intake pipes values vs. pipes at $1500 \mathrm{rpm}$ working operation point for each EGR dispersion level. 112

4.10. Increment of $\mathrm{CO}_{2}$ between pipes vs cylinder at $1500 \mathrm{rpm}$ working operation point for each EGR dispersion level. 113

4.11. $\mathrm{CO}_{2}$ Intake pipes values vs. pipes at $3000 \mathrm{rpm}$ working operation point for each EGR dispersion level. 117

4.12. Increment of $\mathrm{CO}_{2}$ between pipes vs cylinder at $3000 \mathrm{rpm}$ working operation point for each EGR dispersion level. 120

4.13. Air mass flow vs. EGR standard deviation (left), and fuel mass flow vs. EGR standard deviation (right) for the 1250, 1500, 2000, 2500 and $3000 \mathrm{rpm}$ working operation points (from top to bottom). 124 
4.14. Lambda vs. EGR standard deviation (left), and BSFC vs. EGR standard deviation (right) for the 1250, 1500, 2000, 2500 and 3000 rpm working operation points (from top to bottom). 127

4.15. In-cylinder pressure vs cylinder displacement for all the cylinders and different dispersion levels (left) and IMEP for all the cylinders (numbered from 1 to 4 ) and the average (named T) versus EGR rate for different dispersion levels (right) at 1250, 1500, 2000, 2500 and $3000 \mathrm{rpm}$ engine running conditions (from top to bottom). 130

4.16. $\mathrm{O}_{2}$ vs. EGR rate (left), and CO vs. EGR rate (right) at 1250, 1500, 2000, 2500 and $3000 \mathrm{rpm}$ working operation points (from top to bottom)

4.17. Lambda (left), BSFC (center) and opacity (right) vs EGR dispersion at 1250, 1500, 2000, 2500 and $3000 \mathrm{rpm}$ engine running conditions. 137

4.18. Dimensionless opacity vs coefficient of variance of the EGR standard deviation for all the tested engine running conditions. 138

4.19. Instantaneous $\mathrm{CO}_{2}$ concentration in 6 locations of the intake manifold at $2500 \mathrm{rpm}$ and 19 bar BMEP with $4 \%$ of EGR rate working operation point. .140 4.20. Instantaneous $\mathrm{CO}_{2}$ concentration in several location of the intake manifold at $2500 \mathrm{rpm}$ and 10 bar BMEP with $17 \%$ of EGR rate working operation point.

4.21. Instantaneous $\mathrm{CO}_{2}$ concentration in several location of the intake manifold at $1500 \mathrm{rpm}$ and 3 bar BMEP with 3\% of EGR rate working operation point.142 4.22. Instantaneous $\mathrm{CO} 2$ concentration in several location of the intake manifold at $1500 \mathrm{rpm}$ and 1 bar BMEP with $42 \%$ of EGR rate working operation point.

4.23. EGR rate pipe to pipe vs. pipes at $2500 \mathrm{rpm}$ and 11.7 bar BMEP with $19 \%$ of EGR rate and $3000 \mathrm{rpm}$ and 20 bar BMEP with 11\% engine running conditions with different EGR dispersion valves control position, 25-25-75 and 25-50-100 respectively. Each one for two different manifold designs, a new one used in this study and a conventional. 144

4.24. EGR and air mass flow in the EGR and intake lines respectively and, EGR and air mass fraction in the volume where they mix, respectively with three different lengths of the EGR line, including the original, at $2000 \mathrm{rpm}$ and 6 bar 
BMEP working operation point with $23 \%$ of EGR rate. Y-axis represents the mass flow in the first two graphs and the mass fraction in the last two graphs, $\mathrm{X}$-axis represents the crank angle.

4.25. EGR and air mass flow in the EGR and intake lines respectively and, EGR and air mass fraction in the volume where they mix, respectively with three different lengths of the EGR line, including the original, at $2500 \mathrm{rpm}$ and 11.7 bar BMEP working operation point with $20 \%$ of EGR rate. Y-axis represents the mass flow in the first two graphs and the mass fraction in the last two graphs, $\mathrm{X}$-axis represents the crank angle. 150

4.26. EGR mass flow in the EGR with three different lengths of the EGR line, including the original, at $2000 \mathrm{rpm}$ and 6 bar BMEP with 23\% of EGR rate and $2500 \mathrm{rpm}$ and 11.7 bar BMEP with $20 \%$ of EGR rate working operation points (from top to bottom). Y-axis represents the mass flow and X-axis represents the crank angle. 151

4.27. Modeled EGR rate vs. pipes at $2000 \mathrm{rpm}$ and 6 bar BMEP with $23 \%$ of EGR rate and $2500 \mathrm{rpm}$ and 11.7 bar BMEP with $20 \%$ of EGR rate working operation points. Both of them were simulated with different EGR duct length including the original. 152

4.28. Air and EGR mass fraction in the volume where they mix at $1500 \mathrm{rpm}$ and 15 bar BMEP with 5\% EGR rate working operation point in two different designs: conventional intake manifold design and smaller manifold. Y-axis represents the mass fraction and $\mathrm{X}$-axis represents the crank angle. 154

4.29. $1500 \mathrm{rpm}$ and 15 bar BMEP with 5\% of EGR rate, $2500 \mathrm{rpm}$ and 11.7 bar BMEP with $20 \%$ of EGR rate and $3000 \mathrm{rpm}$ and 20 bar BMEP with $11 \%$ of EGR rate with different levels of EGR dispersion, simulated with two different conventional intake manifold sizes. Y-axis represents the EGR rate and X-axis represents the number of the pipes where the flow runs.. 156 4.30. Measured and predicted EGR rate in pipes at $1250 \mathrm{rpm}$ and 11 bar BMEP with around $7 \%$ of EGR rate and with two different EGR dispersion levels: 3333-66 (top) and 25-50-25 (bottom). Y-axis represents the EGR rate and X-axis represents the number of the pipes where the flow circulates. 158

4.31. Measured and predicted EGR rate in pipes at $1500 \mathrm{rpm}$ and 15 bar BMEP with around 5\% of EGR rate and with two different EGR dispersion levels: 33- 
33-66 (left) and 25-75-25 (right). Y-axis represents the EGR rate and X-axis represents the number of the pipes where the flow circulates. 159

4.32. Measured and predicted EGR rate in pipes at $2000 \mathrm{rpm} 6$ bar BMEP with around 23\% of EGR rate two different EGR dispersion levels: 66-25-25 (top) and 25-75-25 (bottom). Y-axis represents the EGR rate and X-axis represents the number of the pipes where the flow circulates. 160

4.33. Measured and predicted EGR rate in pipes at $2500 \mathrm{rpm}$ and $12 \mathrm{BMEP}$ with 20\% of EGR rate and with two different EGR dispersion levels: 25-25-85 (top) and 50-50-50 (bottom). Y-axis represents the EGR rate and X-axis represents the number of the pipes where the flow circulates. 161

4.34. Measured and predicted EGR rate in pipes at $3000 \mathrm{rpm}$ and $20 \mathrm{BMEP}$ with around $12 \%$ of EGR rate and two different EGR dispersion levels: 15-50-100 (left) and 50-100-50 (right). Y-axis represents the EGR rate and X-axis represents the number of the pipes where the flow circulates. 162

4.35. Measured and predicted EGR rate in the pipes at $1500 \mathrm{rpm}$ and $1 \mathrm{bar}$ BMEP with $42 \%, 29 \%, 22 \%$ and $7 \%$ EGR rates from top to bottom and symmetric positions for the EGR dispersion valves 165

4.36. 1500-01，1500-03，2000_25-75-25，2000_66-25-25 and 2500-10 running conditions. Each one changes the EGR rate and the EGR dispersion level. Y-axis represents the COV and $\mathrm{X}$-axis represents the EGR rate. 167

4.37. Measured and predicted COV as a function of the EGR rate in the 39 engine running conditions 168

4.38. Cylinder EGR absolute (top) and relative (bottom) errors as a function of the EGR rate in the 39 engine running conditions (blue dots: cylinders 1 and 4; red crosses: cylinders 2 and 3) 169

4.39. Cylinder EGR relative errors as a function of the non-dimensional RMSE in the 39 engine running conditions (blue dots: cylinders 1 and 4; red crosses: cylinders 2 and 3$)$. 170

4.40. Simulations percentage with lower values of maximum RE (top) and nondimensional RMSE (bottom) with all engine conditions (in red crosses) and engine operation with EGR rate higher than $10 \%$ (in blue dots) 171 
4.41. Symmetry and convexity factors from the experiments as a function of the non-dimensional RMSE in the 39 engine running conditions. 172

4.42. Simulations percentage with lower values of maximum RE (top) and nondimensional RMSE (bottom) with all engine conditions (in red crosses) and engine operation with EGR rate higher than $10 \%$ (in blue dots) to 26 cases with $\mathrm{CF}< \pm 0.4$. 173

4.43. Simulations percentage with lower values of maximum RE (top) and nondimensional RMSE (bottom) with all engine conditions (in red crosses) and engine operation with EGR rate higher than 10\% (in blue dots) to 23 cases with $\mathrm{SF}<0.3$. 175

4.44. Simulations percentage with lower values of maximum RE (top) and nondimensional RMSE (bottom) with all engine conditions (in red crosses) and engine operation with EGR rate higher than 10\% (in blue dots) to 17 cases with $\mathrm{CF}< \pm 0.4$ and $\mathrm{SF}<0.3$. 176 


\section{Index of tables}

2.1. European emissions standard for passenger cars......................................22

2.2. Premature deaths attributed to $\mathrm{PM}_{2.5}$ and $\mathrm{NO}_{2}$ in the EU-28 and in 41

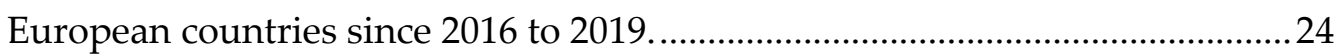

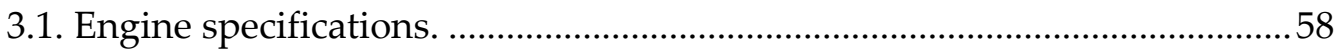

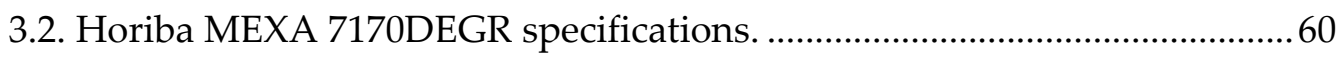

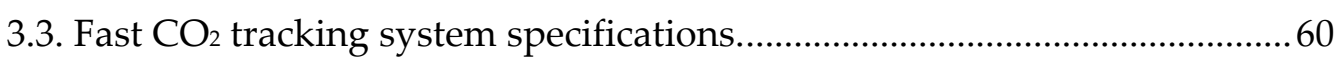

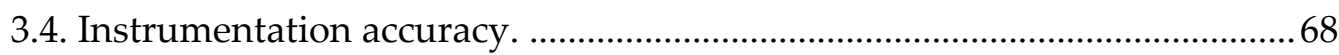

3.5. Working operation points to perform the preliminary study.....................71

3.6. Engine running conditions to perform the detailed study...........................72 



\section{Nomenclature}

\section{Acronyms}

AE: Absolute error

BMEP: Break Mean Effective Pressure

BSFC: Brake Specific Fuel Consumption

CAD: Computer-aided design

CF: Convexity factor

COVID-19: Coronavirus disease 2019

$\mathrm{CO}_{2}$ : Carbon dioxide

DOC: Diesel Oxidation Catalyst

DPF: Diesel Particulate Filter

EAEC: European Atomic Energy Community

ECE: Economic Commission for Europe

ECSC: European Coal and Steal Community

EEC: European Economic Community

EEA: European Environment Agency

EGR: Exhaust Gas Recirculation

EPA: Environment Protection Agency

EUDC: Extra Urban Driving Cycle

EU-28: The 28 countries that formed the European Union (including United Kingdom before Brexit)

FS: Full scale

GM: General Motors 
HC: Hydrocarbons

HP: High Pressure

$\mathrm{H}_{2} \mathrm{O}:$ Water vapor

MRE: Maximum Relative Error

ndRMSE: Non-dimensional root mean square error

NEDC: New European Driving Cycle

NOx: Oxides of nitrogen

$\mathrm{NO}_{2}$ : Nitrogen dioxide

PM: Particulate matter

$\mathrm{PM}_{2,5}$ : Particulate matter over 2,5 $\mu \mathrm{m}$

RDE: Real Driving Emissions test

RE: Relative error

Re: Reynolds number

RPM: Revolutions per minute

SARS-CoV-2: Severe acute respiratory syndrome coronavirus 2

SCR: Selective Catalytic Reduction

SDGs: Sustainable Development Goals

SF: Symmetry factor

S.I: Spark Ignition

UDC: Urban Driving Cycle

UN: United Nations

USA: United States of America

UWS: Urea Water Solutions 
WDE: Water-in-diesel emulsion.

WHO: World Health Organization

WHTC: World Harmonized Transient Cycle

WLTC: Worldwide harmonized Light duty Test Cycle

WLTP: Worldwide harmonized Light vehicles Test Procedures

0D: Non-dimensional or zero-dimensional

1D: One-dimensional

2D: Bi-dimensional

3D: Three-dimensional

\section{Latin characters}

$C_{f}$ : Fanning friction factor

$C_{p}:$ Specific heat

D: Diameter

$h_{f}$ : Pressure Loss Coefficient

$h_{g}:$ Heat transfer coefficient

Pr: Prandtl number

$U_{e f f}$ : Effective velocity

\section{Greek characters}

$\varepsilon$ : Roughness

$\lambda$ : Air to fuel equivalence ratio (i. e. lambda)

$\rho$ : Density 

"It's a dangerous business, Frodo, going out your door. You step onto the road, and if you don't keep your feet, there's no knowing where you might be swept off to."

Bilbo Baggins in The Lord of the Rings, The Fellowship of the Ring by J. R. R. Tolkien

\section{Chapter 1}

\section{Objectives and methodology}





\section{Contents}

1. Objectives and methodology …...................................................................... 1

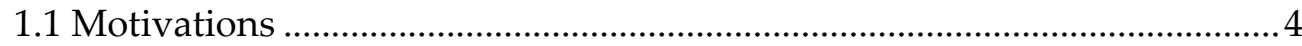

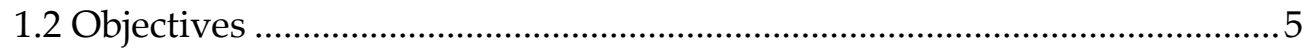

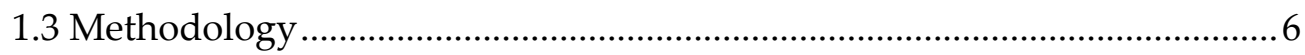

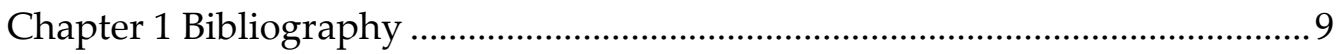




\subsection{Motivations}

In 1967 Syukuro Manabe and Richard T. Whetherald published the first study about the increment of the temperature of the Earth because of the greenhouse gases, specially related to the $\mathrm{CO}_{2}$ emissions. In fact, they elaborated a model that predicted the evolution of the temperature [4].

In 1976, Heinen alerted about the different pollutants emitted by Spark Ignition (S.I.) engines and by Diesel engines, as well as the needed to study the combustion process in Diesel engines [5].

In 2015, the European Environment Agency (EEA) published an air quality report in Europe [6]. The study takes into account 40 European countries including the 28 countries that formed the European Union (EU-28) then. This report shows the health impacts of exposure to fine particulate matter, ozone and nitrogen dioxide $\left(\mathrm{NO}_{2}\right)$. According to the report, the demographic data were taken from the United Nations (UN) in 2012 and the health related data were taken from World Health Organization (WHO) in 2013. The results of the health impact indicated that the premature deaths attributable to $\mathrm{PM}_{2,5}$ amounted to 403.000 in the EU-28 countries and 432.000 in total in the 40 European countries. In addition, the premature deaths attributable to $\mathrm{NO}_{2}$ amounted to 72.000 in the EU-28 countries and 75.000 in total in the 40 European countries.

In 1969, Hurn published that the smoke (which implies PM) and the oxides of nitrogen (NOx) were pollutants typically usual in diesel engines [7].

In 1992, the Economic Commission for Europe (ECE) approves the standard European regulation for light duty vehicles emissions denominated Euro regulations. This standards are regularly updated and they are accompanied by a numbering that indicates the version and their specifications. The first version was the Euro 1 and the last one is the Euro 6, approved in 2014. The regulation differences among the weight, combustion type and vehicle class. Each new regulation is stricter than the previous concerning to the pollutant emissions limitation.

The restrictions are especially hard with PM and NOx emissions, which are particularly difficult to reduce in diesel combustion engines specially because 
there is a trade-off between PM and NOx emissions. In $1996 \mathrm{~N}$. Ladommatos et al. published two studies. On one hand, one of them explained that EGR strategy helped to reduce the NOx emissions thanks to the higher heat absorbing capacity of the EGR combined with the reduction of $\mathrm{O}_{2}$ levels that reduces the flame temperature into the cylinder [8]. On the other hand, the second one explained that the EGR reduced the oxygen to fuel ratio, which produced a reduction of the oxygen available and the local flame temperature in the burning regions, both of them prejudiced the soot oxidation process [9]. Later, in 1998, Ladommatos et al. published a study that analyzed and quantified the effect of the EGR on NOx and particle pollutants jointly, trying to reduce the effect over the particle pollutants, where explained that the introduction of $\mathrm{CO}_{2}$ and $\mathrm{H}_{2} \mathrm{O}$, the principal constituents of the EGR, reduced the NOx but increased the PM emissions [10]. However, A. Maiboom et al. explained in 2008 and 2010 the final effects of the EGR strategies over NOx-PM trade-off and fuel consumption are varied, complex and sometimes contradictories $[11,12]$. One of the causes is that the formation of soot depends of a various factors: pressure, temperature, stoichiometry, fuel composition and fuel structure and not all of them originate soot in a coordinated way [13].

Finally, some studies indicates that EGR unequal distribution among cylinders affects negatively to the NOx-PM trade-off $[14,15,16]$.

\subsection{Objectives}

According to the new regulations to reduce the environmental impact of the automotive engines, more specifically diesel engines, and the importance of the modeling tools nowadays and the effort to reduce the computational cost to improve its efficiency, the objectives of the thesis are mainly two:

- The analysis of the HP EGR dispersion in different working operation points; the study includes a wide set of engine running conditions: speed, load and EGR rate, to observe the consequences on pollutant emissions (especially NOx and PM) and fuel consumption depending on the dispersion level. Furthermore, the desired goal consists on developing a quantification of the admissible HP EGR dispersion level [1]. 
- The development of a one-dimensional (1D) model that predicts the EGR dispersion with accuracy in steady conditions to explore the limits of the 1D modeling. The 1D modeling approach offers many possibilities with a low computational cost. Moreover, the combination of experimental and 1D modeling tools are widely used in engine research [2].

This study offers the possibility to adapt the automotive diesel engines to reduce the pollutant emissions and contribute to the fight against the climate change. In addition, it explores the limits of the 1D modeling in engine research applications.

\subsection{Methodology}

The methodology of the current study combines experimental and modeling tools to perform a very complete research regarding HP EGR dispersion.

The combination of these experimental and modeling tools offers the possibility not only to know the effects of the EGR dispersion on pollutant emissions and fuel consumption, but also the causes of the EGR dispersion and the potential of the 1D modeling.

The need to reduce the smoke and NOx emissions in automotive diesel engines, and the fuel consumption too, motivates this study to quantify the effect of the dispersion on smoke and NOx emissions. The main outcome is to quantify the relationship between opacity and EGR dispersion in several engine running conditions in a diesel automotive engine. This information contributes to increase the knowledge to develop systems to reduce the emissions caused by HP EGR dispersion.

Experimental tools were used to bring about this study, combining traditional and new original devices and systems. All of them offer a lot and interesting information about the levels of the dispersion and the emissions in the exhaust line. Moreover, 1D modeling tools were used too, including the combination of different elements that worked like a quasi-3D model approximation that presents a lower computational cost than a conventional 3D modeling but better accuracy than a traditional 1D modeling. 
After the motivation, objectives and methodology presented in chapter 1, the structure of this thesis is as following: Chapter 2 is dedicated to the review of the state of the art. In this chapter, an introduction related to the internal combustion engines is presented to establish the starting point. Moreover, an explanation of the legislation related to the pollution due to the automotive engines and the air quality is detailed. An explanation of the different types of automotive pollutant emissions is offered too. After the description of the pollutant emissions and the regulations, the passive and active strategies to reduce the pollutant emissions to comply the standards is detailed. Especially attention is dedicated to the EGR strategy, which takes a starring role in this thesis. Furthermore, this thesis is supported over experimental and modeling tools, because of that it is necessary to explain the modeling tools and its application in the fluid dynamic field and, more specifically, in automotive research. Finally, the researching related with the HP EGR dispersion is presented in detail.

In chapter 3 it is possible to find the methodology explaining in detail, both experiments and modeling approach. The experimental setup is presented, including the measuring equipment. Furthermore, the selection of the engine running conditions, and the strategies and their control during the experimental tests. Moreover, a detailed explanation of the modeling tools and its application and utility in this work is offered, especially the OD and 1D models and the quasi-3D approximation. Finally, some metrics related to EGR dispersion that will be used through the document are defined at the end of this chapter too.

Chapter 4 is dedicated to the presentation of the results and discussion. It contains the preliminary study, the stability of the engine running conditions during the test performance, the influence of the EGR dispersion over the pollutant emissions, fuel consumption and in-cylinder pressure. Furthermore, the model assessment is presented along with its capability of prediction. In this chapter the influence of the manifold layout in the capability of prediction and the wave dynamic effect in this particular situation are explained too. In addition, the effect of size of the volumes that compose the intake manifold partially is analyzed. Moreover, the relationship of the EGR rate with the EGR dispersion level is detailed. Finally, the accuracy of the model and the success rate are presented in base on various parameters. 
Finally, chapter 5 presents an exposition regarding the novelties of the methodology and the results offered by it. Additionally, the main conclusions extracted from the results analyzed in chapter 4 are presented in this chapter. Finally, a suggestion of future works to deepen in the knowledge of the EGR dispersion consequences on BSFC and gasoline engines is presented along with the progress in the quasi-3D modeling research. 


\section{Chapter 1 Bibliography}

[1] V. Macián, J. M. Luján, H. Climent, J. Miguel-García, S. Guilain, and R. Boubennec. "Cylinder to cylinder high-pressure exhaust gas recirculation dispersion effect on opacity and NOx emissions in a diesel automotive engine". International Journal of Engine Research (2020). URL: https://doi.org/10.1177/1468087419895401 (cit. on pp. xv, 5, 73, 138, 184).

[2] J. Galindo, H. Climent, R. Navarro, J. Miguel-García, D. Chalet, and P-E. Pretot. "A study on the high pressure EGR transport and application to the dispersion among cylinders in automotive engines". 2020 International Journal of Engine Research (2020). URL: https://doi.org/10.1177/1468087420969263 (cit. on pp. $x v, 6,84,87,172,186)$.

[4] S. Manabe and R. T. Wetherlad. "Thermal Equilibrium of the Atmosphere with a Given Distribution of Relative Humidity". Journal of the Atmospheric Science 24 (3) (1967) (cit. on p. 4).

[5] N. A. Henein. "Analysis of pollutant formation and control and fuel economy in diesel engines". Progress in Energy and Combustion Science 1 (4) (1976), pp. 165-207. URL: https://doi.org/10.1016/0360-1285(76)90013-7 (cit. on p. 4).

[6] European Environment Agency. "Air quality in Europe - 2015 Report". EEA Report No 5/2015 (2015). ISBN 978-92-9213-702-1, ISSN 1977-8449. DOI: $10.2800 / 62459$ (cit. on p. 4).

[7] R. W. Hurn. "Air pollution and the compression-ignition engine". Symposium (International) on Combustion 12 (1) (1969), pp. 677-687. URL: https://doi.org/10.1016/S0082-0784(69)80449-2 (cit. on p. 4).

[8] N. Ladommatos, R. Balian, R. Horrocks, and L. Cooper. "The effect of exhaust gas recirculation on combustion and NOx emissions in a high-speed direct-injection diesel engine". Society of Automotive Engineers, SAE paper 960840, 1996 (cit. on pp. 5, 30).

[9] N. Ladommatos, R. Balian, R. Horrocks, and L. Cooper. "The effect of exhaust gas recirculation on soot formation in a high-speed direct-injection 
diesel engine". Society of Automotive Engineers, SAE paper 960841, 1996 (cit. on pp. $5,30,124)$.

[10] N. Ladommatos, S. M. Abdelhalim, and H. Zhao. “Control of oxides of nitrogen from diesel engines using diluents while minimizing the impact on particulate pollutants". Applied Thermal Engineering 18 (11) (1998), pp. 963980. URL: https://doi.org/10.1016/S1359-4311(98)00031-3 (cit. on pp. 5, 30, 124).

[11] A. Maiboom, X. Tauzia, and J-F. Hétet. “Experimental study of various effects of exhaust gas recirculation (EGR) on combustion and emissions of an automotive direct injection diesel engines". Energy 33 (2008), pp. 22-34. DOI: 10.1016/j.energy.2007.08.010 (cit. on pp. 5, 30, 124).

[12] A. Maiboom, X. Tauzia, S. Shah, and J-F. Hétet. "Experimental Study of an LP EGR System on an Automotive Diesel Engine, compared to HP EGR with respect to PM and NOx Emissions and Specific Fuel Consumption". SAE Int. J. Engines 2 (2) (2010), pp. 597-610. URL: https://doi.org/10.4271/2009-24-0138 (cit. on pp. 5, 124).

[13] D. R. Tree and K. I. Svensson. "Soot processes in compression ignition engines". Progress in Energy and Combustion Science 33 (3) (2007), pp. 272-309. URL: https://doi.org/10.1016/j.pecs.2006.03.002 (cit. on pp. 5, 27, 28, 125, 126).

[14] R. M. Siewert, R. B. Krieger, M. S. Huebler, P. C. Baruah, B. Khalighi, and M. Wesslau. “Modifying and Intake Manifold to Improve Cylinder-to-Cylinder EGR Distribution in a DI Diesel Engine Using Combined CFD and Engine Experiments". 2001 SAE Technical Paper 2001-01-3685, URL: http://dx.doi.org/10.4271/2001-01-3685 (cit. on pp. 5, 40, 67, 187).

[15] A. Maiboom, X. Tauzia, and J-F. Hétet. “Influence of EGR unequal distribution from cylinder to cylinder on NOx-PM trade-off of a HSDI automotive Diesel engine". Applied Thermal Engineering 29 (2009), pp. 20432050. DOI: 10.1016/j.applthermaleng.2008.10.017 (cit. on pp. 5, 40, 67, 187).

[16] H. Lakhlani, J. Barman, K. Rajput, and A. Goswami. “Experimental Study of EGR Mixture Design and its Influence on EGR Distribution Across the Cylinder for NOx-PM Tradeoff". 2013 SAE Int. DOI: 10.4271/2013-01-2743 (cit. on pp. 5,40$)$. 
"A mind needs books like a sword needs a whetstone, if it is to keep its edge. That is why I read so much."

Tyrion Lannister in Song of Fire and Ice, A Game of Thrones

by George R. R. Martin

\section{Chapter 2}

\section{State of the art}





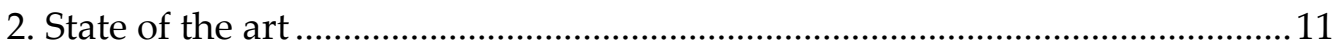

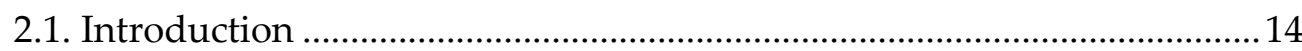

2.2. Air pollution and regulation....................................................................... 16

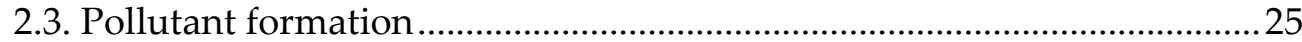

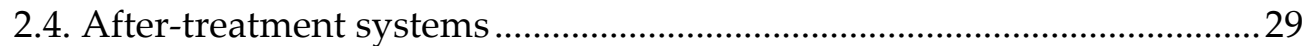

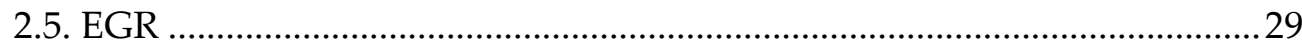

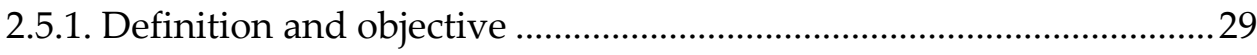

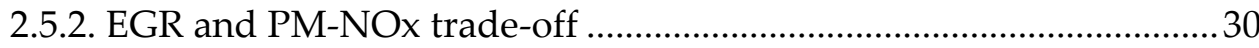

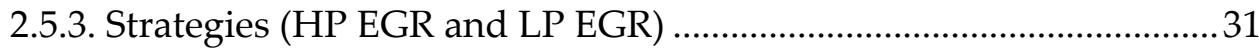

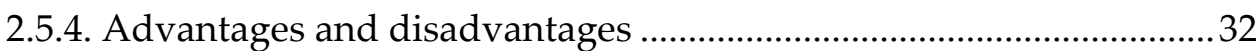

2.5.5. New standards: Low temperatures and transient cycles ................... 32

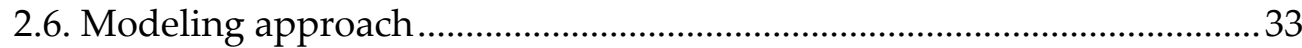

2.6.1. Filling and emptying models................................................................... 34

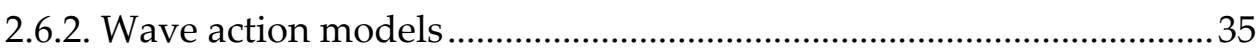

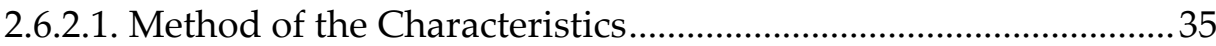

2.6.2.2. Conservative centered schemes ……………...................................35

2.6.2.3. Upwind schemes and Riemann solvers .........................................36

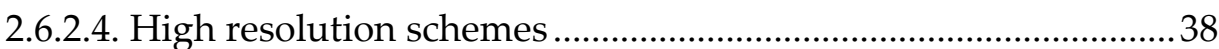

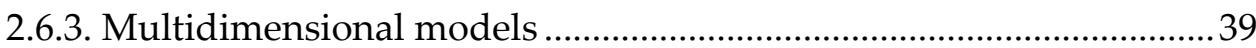

2.7. HP EGR dispersion ..................................................................................... 40

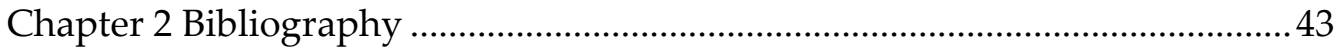




\subsection{Introduction}

The engine automotive industry is directly linked to the First Industrial Revolution (1760-1840) in England during Late Modern Period. It takes place there first, before than other countries, owing to it was a modern and powerful colonial empire that put England at the center of the world on a commercial level, due to all products from the colonies passed thorough there, acting as an intermediary. This brought important economic benefits. Moreover, England had a property system that prioritized the private property against other countries where the ownership of the lands property was not very clear. This property system favored the emergence of an economically powerful bourgeoisie that, in addition, decided to invest looking for new sources of business against the bourgeoisie of other countries. Consequently, they led the industrial process and transformed their economy and society. England was the first country of the world to implant the Parliamentary System inspired in the ideas of Thomas Paine, Jean-Jacques Rousseau, Voltaire and Montesquieu. All of them influenced by Locke and promoters of the American Revolution in the case of Paine and the French Revolution in the case of Rousseau, Voltaire and Montesquieu. Therefore, the economics, politics and social characteristics of England favored the emergence of the Capitalism and, with it, the birth of the First Industrial Revolution. Particularly the First Industrial Revolution was specially influenced by the Scottish James Mill and his son, born in England, John Stuart Mill.

The most important technologic invention of the First Industrial Revolution and that characterized it was the Steam Machine, patented by the Scottish Engineer James Watt (1736-1819) in 1769 based on a previous model named Newcomen Machine, because of its inventor, Thomas Newcomen (1663-1729) what at the same time was inspired on a previous model of Thomas Savery (1650-1715). Later, the Steam Machine invented by Watt and other similar works motivated the studies of the French Physician and Engineer Nicolas Sadi Carnot (17961832). Carnot is considered the father of the thermodynamic due to his work published in 1824 "Reflections on the Motive Power of Fire and on Machines Fitted to Develope that Power" that originated the second law of thermodynamics and described the Carnot cycle. The steam machine patented by James Watt 
presented many uses, the most important were related with the land and sea transport: the railway and the steamboat respectively.

The railway was invented by the English Engineer George Stevenson who presented in 1825 the "Locomotion No 1" the first steam locomotive. Some years before, the American Engineer Robert Fulton invented the steamboat in 1807. The fuel of the steam machine was coal. Firstly vegetal coal and later mineral coal. In fact, the First Industrial Revolution is characterized by the coal extraction mining. Moreover, the First Industrial Revolution was not only characterized by technological advances, but very hard work conditions and pollution. The generalized employed of the mineral coal as fuel began a pollution process that is present already nowadays. The pollution had environmental consequences like smog, acid rain or greenhouse gases emissions but health consequences too related to lung problems due to the soot that produced premature deaths. Those consequences were not attached until the second half of the XX century when different countries like USA or European Countries started to set regulations to control the pollution, as it will explained in detail in the next section.

The Carnot studies inspired other important works. Two especially important: The Lenoir Machine patented in 1860, which is the first internal combustion engine, and the theoretical four stroke at constant volume cycle, patented in 1862 by Beau de Rochas. Later, these works were the precursors of the first internal combustion engine.

The First Industrial Revolution ended and gave rise to the Second Industrial Revolution (1870-1914). This period is characterized, among others, by the new energy sources and new transport systems. The petroleum replaced coal as fuel. It let the apparition of gasoline and with it the first internal combustion engine patented in 1876 by the German Engineer Nikolaus Otto (1832-1891) and based on the works of Lenoir and Beau de Rochas. That same year other German Engineer and Inventor too, Karl Benz (1844-1929), made the first vehicle impulse by a four-stroke engine, the "Benz Patent Motorwagen". In addition, the German Engineer Rudolf Diesel (1858-1913) patented the Diesel engine in 1892. The engine was built finally in 1897 and presented in Paris in 1900. The Second Industrial Revolution was characterized by the discovery of the electricity too. 
In fact the first electric vehicle was invented in the 1830 decade, the exact year is not known, and its invention is attributed to the Scottish Robert Anderson who was based on previous experiments. However, finally the combustion engine prevailed due to technical improvements among other reasons.

The mass production of the Ford T model in 1906 by Henry Ford, between 1908 and 1927, 15 million Ford $\mathrm{T}$ were sold, helped to the prevalence of the combustion engines in automotive industry too. In fact, the Second Industrial Revolution was characterized by new production systems. Two specifically: Taylorism, based on the specialization of work and created by Frederick Taylor (1856-1915), and the Fordism, based on assembly lines that receives its name by Henry Ford. The creation of Fordism system is attributed to Ransom Eli Olds, who design the first low cost vehicle some years before the Ford $\mathrm{T}$, the Curved Dash Oldsmobile produced between 1901 and 1907 and around 19000 units sold. The impact difference between the Ford $\mathrm{T}$ and the Curved Dash Oldsmobile made that Henry Ford popularized the system. In addition, the term was extended by Antonio Gramsci in 1934 due to his essay "Americanism and Fordism". The first Diesel vehicle produced in mass was the Mercedes Benz 260 D presented in Berlin in 1936.

\subsection{Air pollution and regulation}

The regulation and the standards in automotive industry are directly related with C.C. Patterson, who was the first person in the world in dating the age of the Earth with precision. Patterson published in 1956 a study based on the decomposition of the uranium into lead from meteorite to date the age of the Earth in $4.55 \pm 0.07 \times 10^{9}$ years [17]. The relation between this field of study and the automotive industry appeared when Patterson began to have problems to measure the lead of the samples due to the lead contamination in his laboratory, what delayed his research for some years. In fact, due to this problem, Patterson created one of the first clean room in the world. The lead contamination was caused by the industry of the lead additives. Since then, Patterson researched the lead concentration in the environment.

One of the application of lead additives was in the automotive industry. The lead additive in gasoline was used as antiknock agent first of all by General Motors (GM) to the Cadillac, the flagship vehicle of GM, which had an engine 
knock, in the decade of 1920. GM was associated with DuPont to produce the lead additive to gasoline to avoid the knock.

In 1963, M. Tatsumoto and C.C. Patterson published a study related with the concentration of the lead in Atlantic, Pacific and Mediterranean waters and in snow [18]. The samples of snow were taken from a National Park and the water samples were taken from the surface and the deep of the waters. The lead concentration in the snow was high and it could be caused due to the lead procedure from gasoline exhausts. The concentration of the lead in the surface Mediterranean and Pacific waters were higher than in the depth of the same stations. In the Atlantic waters, the concentration of the lead did not follow a so uniform trend, however the deepest samples showed lower values of lead concentration. The study pointed out that this difference was because of the mixture of the water between the surface and the depth takes long time. Therefore, the precedence of the high values of lead in the surface waters appeared in the last decades, which was relatively short time regarding to the mixture of the waters, and it probably was due to the contamination. Moreover, in the depth, the lead values are lower due to the water precedence was older and it was not contaminated because of human industrial activity. In fact, the study contemplates that the bulk of the lead in the surface of the oceans could come from leaded gasolines.

At the beginning of the $\mathrm{XX}$ century, it was known that high quantities of lead was toxic to humans, but it was not known how much. Consequently, it was not known that the lead waste in that moment was damaging the health of the population. In fact, it was considered that the lead levels in blood and atmosphere were natural when they were artificially increased actually due to the lead additives, which contaminated the people, the atmosphere and the environment. Therefore, the typical levels, considered as natural, were higher than the centuries before during the evolution of the world when the industry did not contaminated the environment. The industry used lead additives in pigments, cosmetics, gasoline or insecticides among others.

In 1965, C.C. Patterson published other study that alerted about the danger of the leads additives, like in gasoline [19], due to the increment of waste lead presence in the environment, the atmosphere and the blood of the people. This 
study was rebutted by R.A. Kehoe that published a letter in 1965, in the same journal than the study of Patterson, as Letters to the Editor [20] alluding to methodological fails and ignorance in the human health field in the study of Patterson.

Kehoe was employed by GM in the 20's when some workers in the plants of GM and DuPont became crazy and died because of lead poisoning. Kehoe affirmed that the lead was a natural component in the human biochemistry and the dangerous quantities, which could cause poisoning, were only present in high expositions like the factory workers where it could be taken preventive measurements. Since the 20 's to the 60 's the industry was the only source to research about the lead and most of that researches were directed by Kehoe, because of that Kehoe became the greatest expert in lead in the world, until the arrival of Patterson [21].

The Congress enacted the first Clean Air Act in the United States of America (USA) in 1955, the Air Pollution Control Act. It was focused on providing funds to research regarding to the air pollution. Some years later, in 1963, the next Act was enacted, the Clean Air Act, which was the first legislation to control air pollution in the USA thanks to a federal program within the United States Public Health Service. Precisely the United States Public Health Services funded the study of Patterson, published in 1965, by a grant.

The Clean Air Act of 1963 was amended for the first time in 1965 by the Motor Vehicle Air Pollution Act. Thanks to this modification, the federal government could establish standards to control the pollutant emissions like lead, but hydrocarbons, sulfur oxides, ozone or nitrogen oxides too, among others; beginning with the 1968 models.

The Environment Protection Agency (EPA) was founded in 1970 as an independent agency for environmental protection. This agency administrated the Clean Air Acts since then. Finally, in 1978, the EPA published new standards for lead [22] in the EPA press release. In this press release, Douglas Michael Costle, the third Administrator of the EPA, affirmed that about the $90 \%$ of total air lead emissions came from automobile exhaust and it was necessary to phase down leaded gasoline. 
The most extensive studies related to the blood lead concentrations in the USA between 1976 and 1991 were the National Health and Nutrition Examination Surveys (NHANES). The NHANES II analyzed the period between 1976 and 1980, and NHANES III analyze the period between 1988 and 1991. In 1994 Pirkle, J. L. et al. [23] published a study based on a compilation among three surveys, NHANES II, NHANES III and Hispanic Health and Nutrition Examination Survey (HHANES) where they concluded that the mean lead level in blood in persons between 1 and 74 years old since 1976 to 1991 had dropped a $78 \%$. Moreover, they conclude that the major cause of it was most likely the removal of lead of gasoline and soldered cans.

Although the Soviet Union was the first country in the world to restrict the use of lead in gasoline, since the 70's many countries limited or eliminated it, due to the health risks of lead exposure and the introduction of catalytic converters, like Japan, Canada, South Korea and some countries of South America and Europe. However, it was difficult to quantify with precision the impact of leaded gasoline on lead blood levels. The lead exposition was due to cosmetics, paint, soldered food cans and others too. There was much controversy about the contribution of leaded gasoline to lead blood levels. In any case, it was clear that it was a significant contribution and several studies showed strong and consistent relationships between gasoline lead and blood lead. The transition to unleaded gasoline was beneficial to the public health and it did not present many technical problems despite alarms like the problem of valve-seat recession, it was necessary other additives but always taking into account the health and environmental risks and the use of catalytic converters. Moreover the cost of transition was not relatively expensive, $0.01 \$ / 1$ [24].

Therefore, the phasedown of leaded gasoline began in 1974, due to the EPA regulations to protect the catalytic converters and the health risks. The catalytic converters were needed to meet the standards emissions of hydrocarbon (HC), NOx and CO. The leaded gasoline damage the catalytic converters. On the other hand, diverse studies showed that lead pollution had health consequences in adults like hypertension or higher blood pressure. In addition it had a negative impact in children too, affecting to them cognitive performance $[25,26]$. At the beginning of the 80 's the leaded gasoline levels dropped an $80 \%$. Leaded gasoline was finally banned in the USA in 1996 [27]. 
As it is explained, the lead pollution owing to leaded gasoline detonated a worry about the automotive emissions. Nevertheless, it was only the first of many. Since then, automotive industry has adapted its technology to reduce the negative impact in the health of the people and in the environment. The USA was the first to create a specific organism to control the emissions and established some standards, but it was followed by other countries like Europe, Japan and China.

The first steps of the regulation in Europe began in 1970 with the "Council Directive 70/157/EEC of 6 February 1970 on the approximation of the laws of the Member States relating to the permissible sound level and the exhaust system of motor vehicles" of the European Economic Community (EEC), founded in 1957 by the Treaty of Rome. Later, in 1993, the European Union was founded in base of the union of the three preexistent European Communities by the Treaty of the European Union: The already mentioned European Economic Community, the European Coal and Steel Community (ECSC) and the European Atomic Energy Community (EAEC).

However, the first European emission standard did not appeared until 1988, the Euro 0 that applied to $\mathrm{N}_{2}$ and $\mathrm{N}_{3}$ category vehicles (goods transport with max mass under 3.5 tons, and between 3.5 and 12 tons respectively). The standards is different depending on of the type of vehicle, fuel, mass or application. Table 2.1 shows the evolution of the European emission standard for passenger cars, diesel on the top and gasoline on the bottom. The limits of $\mathrm{CO}$, total hydrocarbon content (THC), NOx and PM are going down progressively. The limits are different for diesel or gasoline engines due to the different type of combustion process and working conditions, which generate different proportions of pollutant emissions. Gasoline engines produce more CO emissions, so the limit is higher than in diesel engines, and diesel engines produce more NOx and PM, so the limitation is softer than gasoline to those pollutant emissions.

The Euro standards do not contemplate the $\mathrm{CO}_{2}$ emissions in the test procedures and did not established limits to the automotive industry. The $\mathrm{CO}_{2}$ are directly correlated to the fuel consumption, which use to be higher in gasoline than in diesel engines. Therefore, the way to reduce them is different 
than the other pollutant emissions. In that way, the National Highway Traffic Safety Administration (NHTSA) of the USA adopted the Corporative Average Fuel Economy (CAFE) standards in 1975 and remains in force nowadays evolving over the time to reduce the $\mathrm{CO}_{2}$ emissions. The CAFE regulates the miles travelled by a vehicle on a gallon of fuel, controlling the $\mathrm{CO}_{2}$ emissions through the fuel consumption. Since 2008 the EU establishes $\mathrm{CO}_{2}$ limitations, like CAFE legislation in the USA.

The Euro standards testing procedures have been evolved over the time too. Initially, Euro 1 and 2 were tested by the Motor Vehicle Emissions Group A (MVEG-A) cycle divided in two combined parts. Firstly four Urban Driving Cycles (UDC) and secondly two Extra Urban Driving Cycles (EUDC). At the beginning of the cycle, in Euro 1 and 2, were an idling period that heated the engine, which reduced the emissions due to the better working conditions of the engine at higher temperatures. This idling period was removed in 2000 with the Euro 3 and it gave rise to the MVEG-B, commonly known as New European Driving Cycle (NEDC), which measured the engine cold start emissions. However, the NEDC did not represent the real driving conditions due to its soft transitions among other reasons. It is a very regular driving cycle, very different of the real driving conditions. Because of that, in 2018 the Worldwide harmonized Light duty Test Cycle (WLTC) was adopted by the EU and is part of the Worldwide harmonized Light vehicles Test Procedures (WLTP), that aim to be a worldwide standard. The WLTP were launched by the ECE and were also accepted by India, Japan and South Korea. The WLTP is normalized by (CE)2009/443 legislation and establishes $\mathrm{CO}_{2}$ limitations. The WLTC is characterized by dynamic and transient operations divided in four parts: low, medium-low, high and extra-high. In addition the WLTC is lasts longer than the NEDC. In summary, the WLTC is more similar to the real driving conditions. In addition, the Real Driving Emissions (RDE) were implemented along with the WLTC. The RDE consist on the installation of portable measurement device, On Board Diagnostics (OBD), to control the real driving emissions. 
Table 2.1.

European emissions standard for passenger cars.

\begin{tabular}{|c|c|c|c|c|c|c|}
\hline Diesel & Date & $\begin{array}{c}\text { CO } \\
{[\mathrm{g} / \mathbf{k m}]}\end{array}$ & $\begin{array}{c}\text { THC } \\
{[\mathbf{g} / \mathbf{k m}]}\end{array}$ & $\begin{array}{c}\text { NOx } \\
{[\mathrm{g} / \mathbf{k m}]}\end{array}$ & $\begin{array}{c}\mathbf{H C}+ \\
\mathbf{N O x} \\
{[\mathbf{g} / \mathbf{k m}]}\end{array}$ & $\begin{array}{c}\text { PM } \\
{[\mathrm{g} / \mathbf{k m}]}\end{array}$ \\
\hline Euro 1 & $07 / 1992$ & 2.72 & - & - & 0.97 & 0.14 \\
\hline Euro 2 & $01 / 1996$ & 1.0 & - & - & 0.7 & 0.08 \\
\hline Euro 3 & $01 / 2000$ & 0.66 & - & 0.5 & 0.56 & 0.05 \\
\hline Euro 4 & $01 / 2005$ & 0.5 & - & 0.25 & 0.30 & 0.025 \\
\hline Euro 5 & $09 / 2009$ & 0.50 & - & 0.18 & 0.23 & 0.005 \\
\hline Euro 6 & $09 / 2014$ & 0.50 & - & 0.08 & 0.17 & 0.0045 \\
\hline
\end{tabular}

\begin{tabular}{|c|c|c|c|c|c|c|}
\hline Gasoline & Date & $\begin{array}{c}\text { CO } \\
{[\mathrm{g} / \mathbf{k m}]}\end{array}$ & $\begin{array}{c}\text { THC } \\
{[\mathrm{g} / \mathbf{k m}]}\end{array}$ & $\begin{array}{c}\text { NOx } \\
{[\mathrm{g} / \mathbf{k m}]}\end{array}$ & $\begin{array}{c}\mathbf{H C}+ \\
\mathbf{N O x} \\
{[\mathrm{g} / \mathbf{k m}]}\end{array}$ & $\begin{array}{c}\text { PM } \\
{[\mathrm{g} / \mathbf{k m}]}\end{array}$ \\
\hline Euro 1 & $07 / 1992$ & 2.72 & - & - & 0.97 & - \\
\hline Euro 2 & $01 / 1996$ & 2.20 & - & - & 0.5 & - \\
\hline Euro 3 & $01 / 2000$ & 2.30 & 0.20 & 0.15 & - & - \\
\hline Euro 4 & $01 / 2005$ & 1.0 & 0.10 & 0.08 & - & - \\
\hline Euro 5 & $09 / 2009$ & 1.0 & 0.10 & 0.06 & - & 0.005 \\
\hline Euro 6 & $09 / 2014$ & 1.0 & 0.10 & 0.06 & - & 0.0045 \\
\hline
\end{tabular}

In addition, the number of particulates (PN) started to be limited to $6 \times 10^{11}$ $[\mathrm{Nb} / \mathrm{km}]$ since Euro 5 for diesel engines and since Euro 6 for gasoline engines. Therefore, it is clear that in the last years, the regulation is becoming more restrictive, especially concerning NOx and PM emissions in diesel engines. Figure 2.1 presents a color graph with the evolution of the standards regarding NOx and PM emissions in Diesel passenger cars. The Euro 1 approved in 1992 allowed the emission of $0.97 \mathrm{~g} / \mathrm{km}$ of NOx plus HC and $0.14 \mathrm{~g} / \mathrm{km}$ of PM. Euro 2, approved in 1996, entailed a big step and reduced the NOx plus HC emissions to $0.7 \mathrm{~g} / \mathrm{km}$ and PM emissions to $0.08 \mathrm{~g} / \mathrm{km}$, close to $50 \%$ less in the last case. The NOx and THC started to be restricted separately in Euro 3, approved in 2000, the limitation to NOx and PM in this regulation was 0.5 and $0.05 \mathrm{~g} / \mathrm{km}$ respectively. The Euro 4 approved in 2005 halved the limits to 0.25 and 0.025 $\mathrm{g} / \mathrm{km}$ respectively to NOx and PM emissions. The reduction of the Euro 5 to 
NOx emissions was not too hard, $0.18 \mathrm{~g} / \mathrm{km}$, but it was to PM emissions, up to $0.005 \mathrm{~g} / \mathrm{km}$, the third part compared to the previous. Finally, the last actualization was the Euro 6 in 2014 which the NOx limit was reduced to 0.08 and the PM was practically the same, $0.0045 \mathrm{~g} / \mathrm{km}$.

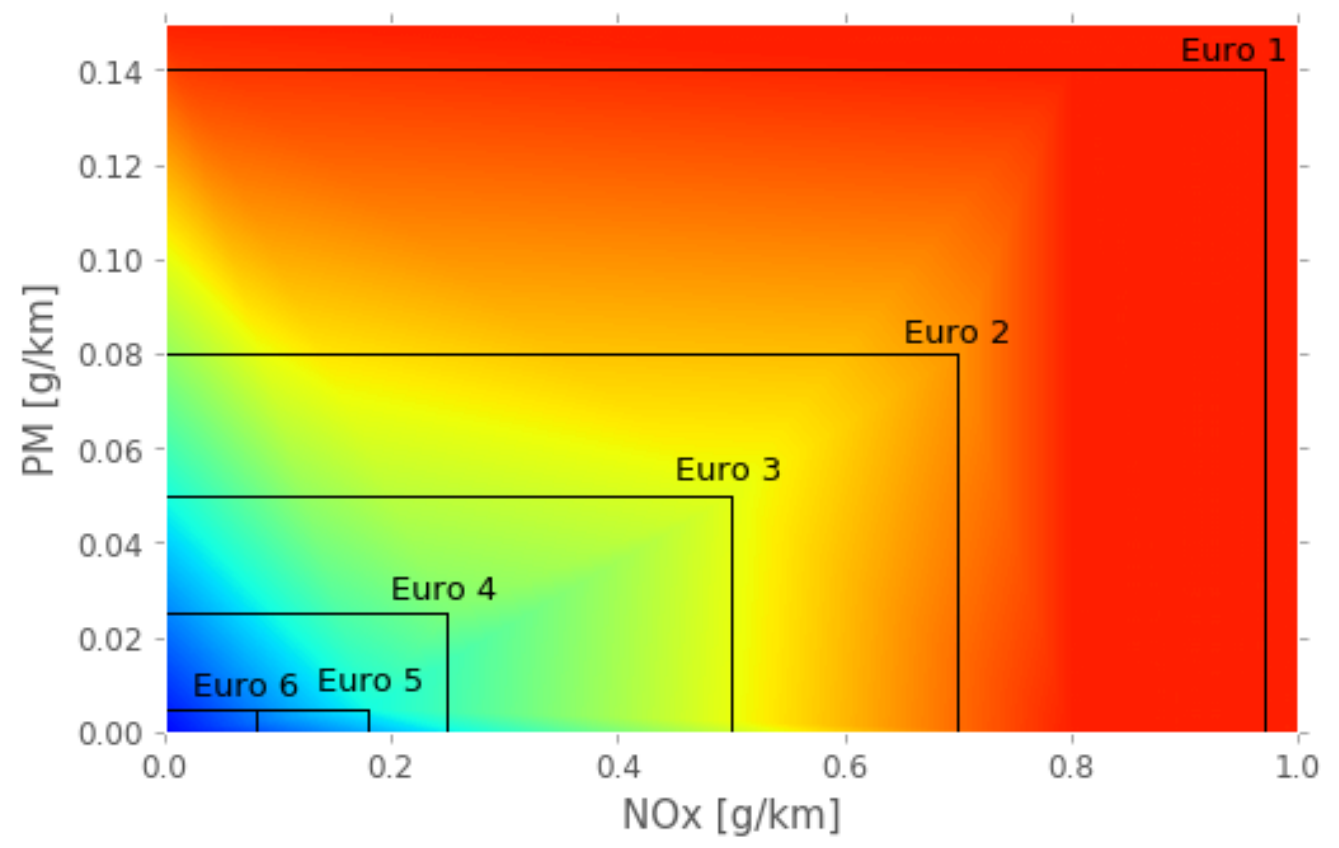

Figure 2.1. PM vs. NOx emissions, both of them in $\mathrm{g} / \mathrm{km}$, at the different European emissions standards from Euro 1 to Euro 6 for Diesel passenger cars.

In section 1.1 it was mentioned an air quality report from the EEA performed in 2015. Similar reports were performed by the same agency in 2016, 2017, 2018 and 2019 [28, 29, 30,31]. The data in table 2.2 shows the premature deaths attributed to $\mathrm{PM}_{2.5}$ and $\mathrm{NO}_{2}$ exposure in 2013, 2014, 2015 and 2016 respectively, all of them in the EU-28 and in 41 European countries, one more country than in the report of 2015 because Kosovo is considered separately from Serbia in the last 4 reports but not in the report of 2015. However, the population is the same, so the results allow a fair comparison. Regarding $\mathrm{NO}_{2}$ emissions the values does not present a falling or upward trend. In the case of $\mathrm{PM}_{2.5}$ a falling trend is observed in the last years. 
Table 2.2.

Premature deaths attributed to $\mathrm{PM}_{2.5}$ and $\mathrm{NO}_{2}$ in the EU-28 and in 41 European countries since 2016 to 2019.

\begin{tabular}{|c|c|c|c|c|}
\hline & PM$_{2.5}$ EU-28 & $\mathbf{P M}_{2.5}$ 41 EC & $\mathbf{N O}_{2}$ EU-28 & $\mathbf{N O}_{2}$ 41 EC \\
\hline $\mathbf{2 0 1 6}$ & 436000 & 467000 & 68000 & 71000 \\
\hline $\mathbf{2 0 1 7}$ & 399000 & 428000 & 75000 & 78000 \\
\hline $\mathbf{2 0 1 8}$ & 391000 & 422000 & 76000 & 79000 \\
\hline $\mathbf{2 0 1 9}$ & 374000 & 412000 & 68000 & 71000 \\
\hline
\end{tabular}

These numbers, along with the climate change, worry to the population at different levels and the international community started taking actions. The Paris Agreement was signed in 2016 by 189 parts including the EU. The objective of the Paris Agreement is to keep the global warming under $2{ }^{\circ} \mathrm{C}$ and it tries to limit it at $1.5^{\circ} \mathrm{C}$. Moreover, following the fulfillment of the Paris Agreement, the international movement Fridays For Future was founded in 2018 by students from different countries. This international movement demanded to the governments around the world to take actions to prevent the climate change and a transition to renewable energies system. These actions demonstrate the worry of the population, especially of the youngest, about the Climate Change and the environment health.

In addition, the Sustainable Development Goals (SDGs) or Global Goals were set in September 2015 and establishes 17 different goals to achieve by the year 2030. This is known as "Agenda 2030" due to a resolution of the United Nations. Several of these goals make reference to improve the quality of the air and to reduce the deaths due to the air pollution, which are directly related to the PM and NOx diesel emissions like Table 2.2 showed.

In this way, the European Commission, elected in 2019 and known as the "von der Leyen Comission" due to its President: Ursula von der Leyen, established the European Green Deal as one of the most important plans, especially after the COVID-19 crisis. Moreover, the European Green Deal is presented as key in the recovery and reconstruction plan of the EU. The main objective of this plan is to "transform Europe in the first climate neutral continent in 2050 boosting the economy, improving the health and quality of life of citizens, protecting nature 
and leaving no one behind" like the European Commission itself communicated in a press release in December $11^{\text {th }} 2019$.

In fact, a study realized by Ogen in April 2020 showed that the chronic exposure at high levels of $\mathrm{NO}_{2}$ in areas like Madrid or Northern Italy could contribute to higher fatality rates due to COVID-19 [32]. This contribution could be consequence of the effects of the $\mathrm{NO}_{2}$ on the lungs. In this way, like Coticini et al. published in 2020, the exposition to highly contaminated areas ( $\mathrm{PM}$ and $\mathrm{NO}_{2}$ but $\mathrm{O}_{3}$ and $\mathrm{SO}_{2}$ too) could explain higher lethality rates of a viral agent like SARS-CoV-2 [33].

Following the European Green Deal and the Paris Agreement, the Government of Spain approved the Climate Change and Energy Transition Bill and it is waiting to be approved in the House of Representatives. Article 12 of this bill, entitled "Promotion of mobility without emissions" purposes to achieve a fleet of passenger cars and light commercial vehicles without direct emissions of $\mathrm{CO}_{2}$ in 2050. Moreover, the new passenger cars and light commercial vehicles, excepting the non-commercial uses historical vehicles, must emit $0 \mathrm{gCO} / \mathrm{km}$ before 2040. In addition, the cities with more than 50000 inhabitants must establish low emissions areas before 2024. And some other measurements not so directly related with the automotive vehicles.

The new regulations and the trend of the international agreements, to slow down the climate change and improve the air quality of the cities to reduce the negative health consequences, implies a very strong emissions reduction horizon for automotive vehicles in the coming years.

The fuel consumption or the $\mathrm{CO}_{2}$ emissions was in the focus of the research the last years. Moreover, the NOx and PM emissions were considered very relevant too. The population is increasingly concerned about the climate change and the air quality of the cities. Because of that, the efforts and the laws are increasing and developing in this way.

\subsection{Pollutant formation}

It is important to know how the emissions are formed to develop strategies to reduce their creation. The NOx is composed by three types: $\mathrm{NO}, \mathrm{NO}_{2}$ and $\mathrm{N}_{2} \mathrm{O}$. In 1991 K. M. Nichols et al. wrote a review about the mechanisms that forms the 
NOx. That review explains that the most of NOx due to the combustion process is composed by NO [34]. There are 3 different mechanisms responsible of the NO formation: Thermal, prompt and intermediate $\mathrm{N}_{2} \mathrm{O}$ [35].

The thermal mechanism was described for the first time by Zeldovich in 1946 in two steps as it is showed in Equations (2.1) and (2.2) [36]:

$$
\begin{aligned}
& O+N_{2} \leftrightarrow N O+N \\
& N+O_{2} \leftrightarrow N O+O
\end{aligned}
$$

The first step has a very high activation energy, so it needs high temperatures to produce a significant quantity of NO. Because of that this mechanism is designed as thermal. Later, in 1970, Levoie et al. [37] proposed a third reaction (2.3) based on the work of Campbell et al. in 1968 [38]. The three reactions together are known as extended Zeldovich mechanism.

$$
N+O H \leftrightarrow N O+H
$$

The prompt mechanism was theorized because NO concentrations were detected higher than the predicted by thermal mechanism. Fenimore [39] proposed in 1971 that it was due to the hydrocarbons coming from the fuel decomposition reacted with the $\mathrm{N}_{2}$, the reaction gives rise intermediate species that finally will form NO. It is described by the following equations:

$$
\begin{aligned}
& \mathrm{CH}+\mathrm{N}_{2} \leftrightarrow \mathrm{HCN}+\mathrm{N} \\
& \mathrm{C}+\mathrm{N}_{2} \leftrightarrow \mathrm{CN}+\mathrm{N} \\
& \mathrm{CH}_{2}+\mathrm{N}_{2} \leftrightarrow \mathrm{HCN}+\mathrm{NH} \\
& \mathrm{CH}_{2}+\mathrm{N}_{2} \leftrightarrow \mathrm{H}_{2}+\mathrm{CN}+\mathrm{N}
\end{aligned}
$$

Finally, the intermediate $\mathrm{N}_{2} \mathrm{O}$ mechanism takes place at low temperatures. Once again, Lavoie et al. explained this mechanism properly in 1970 through the following equations [37] based on the studies of Schofield in 1967 [40]:

$$
\begin{aligned}
& \mathrm{H}+\mathrm{N}_{2} \mathrm{O} \leftrightarrow \mathrm{N}_{2}+\mathrm{OH} \\
& \mathrm{O}+\mathrm{N}_{2} \mathrm{O} \leftrightarrow \mathrm{N}_{2}+\mathrm{O}_{2} \\
& \mathrm{O}+\mathrm{N}_{2} \mathrm{O} \leftrightarrow \mathrm{NO}+\mathrm{NO}
\end{aligned}
$$

Although the $\mathrm{NO}$ is the most common nitrogen oxide in NOx formation, $\mathrm{NO}_{2}$ could achieve high values in Diesel engines. The formation of $\mathrm{NO}_{2}$ is related to 
cooling process. However, $\mathrm{NO}_{2}$ is difficult to measure and its impact and formation process is not very clear. $\mathrm{NO}_{2}$ contributes to acid rain and smog. The reactions are defined in the following equations:

$$
\begin{aligned}
& \mathrm{NO}+\mathrm{HO}_{2} \rightarrow \mathrm{NO}_{2}+\mathrm{OH} \\
& \mathrm{NO}_{2}+\mathrm{H} \rightarrow \mathrm{NO}+\mathrm{OH} \\
& \mathrm{NO}_{2}+\mathrm{O} \rightarrow \mathrm{NO}+\mathrm{O}_{2}
\end{aligned}
$$

The third compound of $\mathrm{NOx}$ is $\mathrm{N}_{2} \mathrm{O}$. Although its proportion is very low in $\mathrm{NOx}$ emissions, it is very effective as responsible gas of the greenhouse effect and the destruction of the stratospheric ozone. The $\mathrm{N}_{2} \mathrm{O}$ formation is related to $\mathrm{HCN}$ and $\mathrm{NH}_{3}$ as the following equations show:

$$
\begin{aligned}
& \mathrm{HCN}+\mathrm{OH} \leftrightarrow \mathrm{HNCO}+\mathrm{H} \\
& \mathrm{HNCO}+\mathrm{OH} \leftrightarrow \mathrm{NCO}+\mathrm{H}_{2} \mathrm{O} \\
& \mathrm{HCN}+\mathrm{O} \leftrightarrow \mathrm{NCO}+\mathrm{H} \\
& \mathrm{NCO}+\mathrm{NO} \rightarrow \mathrm{N}_{2} \mathrm{O}+\mathrm{CO} \\
& \\
& \mathrm{NH}_{3}+\mathrm{OH} \rightarrow \mathrm{NH}_{2}+\mathrm{H}_{2} \mathrm{O} \\
& \mathrm{NH}_{2}+\mathrm{OH} \rightarrow \mathrm{NH}+\mathrm{H}_{2} \mathrm{O} \\
& \mathrm{NH}+\mathrm{NO} \rightarrow \mathrm{N}_{2} \mathrm{O}+\mathrm{H}
\end{aligned}
$$

The $\mathrm{N}_{2} \mathrm{O}$ formation is related to low temperatures and low fuel-to-air ratios, so the commonly used in Diesel engines, EGR strategy that reduce $\mathrm{NO}$ and $\mathrm{NO}_{2}$ emissions, could increase $\mathrm{N}_{2} \mathrm{O}$ emissions [41].

On the other hand, PM emissions depends of the soot formation during the combustion and the dilution process in the exhaust. The soot formation takes place in Diesel engines at high temperatures and high local fuel-to-air ratio conditions. In 2007, Tree et al. wrote a review [13] based on a lot of studies including the previous reviews realized by Smith in 1981 [42] or Haynes and Wagner in 1981 too [43]. However, technologies development in Diesel technologies such as the increment of injection pressure, the reduction of nozzle diameters or new in-cylinder measurements forced a new review on the soot formation process. Otherwise, the works of Smith and, Haynes and Wagner, are deeper and more detailed. 
Tree et al. explained in their work that the soot substance is not very clearly defined, but it is formed in high fuel-to-air ratio located areas at high temperatures due to unburned fuel that nucleated from vapor to solid. Generally, the soot process could be summed up in 6 steps: pyrolysis, nucleation, surface growth, coalescence, agglomeration and oxidation. The first five are sequential and comprises the soot formation, and the oxidation could be happen in different moments of the process and transform the hydrocarbons in $\mathrm{CO}, \mathrm{CO}_{2}$ and $\mathrm{H}_{2} \mathrm{O}$. So, the final soot formation is a balance between the five steps that produce soot and the oxidation process that avoids it.

Oxidation is the process which takes place the conversion of the carbon or hydrocarbons to combustion products. When carbon is partially oxidized to $\mathrm{CO}$, it will not be soot anymore. The oxidation take place at temperatures higher than $1300 \mathrm{~K}$ according to Glassman [44]. The alteration of the molecular structure of the fuel takes place at high temperatures without significant oxidation during the pyrolysis process. The species created due to the pyrolysis are the precursors of the soot. The nucleation is the process which turns the gas phase to solid phase at high temperatures and local rich fuel regions. There is not agreement about the precise temperature that originates the nucleation, the reports vary between 1300 and $1600 \mathrm{~K}$ according to Tree et al. These nucleus influences a lot in the final soot production due to the surface growth process. The surface growth is the process that adds mass to the surface of the nucleus. When exactly this process takes place is not clear, but it is more or less simultaneous to the nucleation process. This is the process that more mass ads to the particles and it takes place at high temperatures too. The number of particles keeps invariable during surface growth process [41]. Finally coalescence and agglomeration are very similar processes that take place at the end of the sequence. They consist on the combination of the particles but in different ways. The coalescence is the process whereby the particles collide and coalesce, so contrary to the growing surface process, the mass keeps constant and the number of particulates is reduced. On the other hand, the agglomeration process consists on the combination of individual or primary particles in large groups forming chains of particles [13].

In the last years, the focus is over diesel engines emissions, especially soot but NOx too. During past decades, a lot of technologies and strategies have been 
developed to reduce the emissions and comply the regulations. One of the most famous and popular strategy to reduce NOx emissions in diesel automotive engines is the EGR although it increases the soot emissions [45, 46], which involves a compromise between NOx and soot emissions.

\subsection{After-treatment systems}

EGR system is not the only strategy to reduce NOx emissions. Nowadays there are new after-treatment systems such as Selective Catalytic Reduction (SCR) based on Urea Water Solutions (UWS) which react with NOx in the exhaust when the solution is injected. The reaction reduces the NOx emissions notably. This system is adapting to the new requirements like the World Harmonized Transient Cycle. It is being applied to diesel engines in transient operations by a specific thermal management since the catalyst activity decreases significantly if the exhaust temperature is lower than $200{ }^{\circ} \mathrm{C}$ [47] or higher than $500{ }^{\circ} \mathrm{C}$. In addition, this system presents a problem of thermal aging because of the high temperatures of the exhaust gases. Moreover SCR is low effective in urban areas because the temperature in the exhaust is usually lower than $200{ }^{\circ} \mathrm{C}$.

Other problem presented by this system is the poisoning due to the sulfur content in the fuel, unburned hydrocarbons and Pt-Pd from the Diesel Oxidation Catalyst (DOC) and Diesel Particulate Filter (DPF) which is explained by Bin Guan et al. in a review of the state of the art technologies of SCR in 2014 [48]. More disadvantages are presented by this system like the deposits of urea and its byproducts during cold weather conditions and low exhaust temperature [49]. Furthermore this control penalizes the fuel consumption far than idle speed because of the increase of the backpressure. The control implies an increment of urea consumption too and it is mandatory to take into account the economic spending to load the tank with UWS. Finally this system presents economical disadvantages compared to EGR.

\subsection{EGR}

\subsubsection{Definition and objective}

The Exhaust Gas Recirculation is a strategy that consist on recirculating the gases of the combustion process from the exhaust to the intake line. The EGR inhibits the NOx formation mainly due to the reduction of the peak combustion 
temperature and the oxygen concentration as explained by Ladommatos et al. in 1996 and 1997 [50, 51, 52, 53]. The benefits of EGR are observed on other applications like industrial natural gas engines [54]. However, the EGR strategies present some disadvantages such as the increase of soot levels, as it was commented before. The oxygen reduction during the combustion process avoids the oxidation of the soot. Moreover, the reduction of the flame temperature reduces the soot oxidation too [9]. On the other hand, the EGR cooling increases the $\mathrm{CO}_{2}$ and $\mathrm{H}_{2} \mathrm{O}$ flow, improving the heat absorbing capacity which reduces the combustion temperature. Otherwise, the slight rise of $\mathrm{O}_{2}$ could increase the flame temperature, hence the NOx [55]. Therefore, the balance is not clear, but the increment of $\mathrm{O}_{2}$ could improve the oxidation of the soot, reducing its levels like Ladommatos et al. demonstrated in different publications between 1996 and 2000 [8, 10, 56].

\subsubsection{EGR and PM-NOx trade-off}

There is a compromise between PM and NOx emissions, which are inversely related. As the regulation according on NOx emissions advances, the strategies become more complex and the EGR rates increase. In that way, A. Maiboom et al. $[11,57,58]$ performed interesting studies, subsequent to Ladommatos et al., related to EGR cooled benefits and the influence of different EGR strategies on NOx and PM emissions at different engine running conditions. First of all [11], HP EGR cooled at low load conditions and constant boost pressure, high EGR rates presents both low, NOx and PM emissions due to the delayed combustion process. Otherwise BSFC, $\mathrm{CO}$ and $\mathrm{HC}$ present a significant increment. Furthermore, for some running conditions, EGR at constant air-to-fuel ratio reduces significantly NOx emissions and do not penalize BSFC and soot emissions, although contrary effect were observed in other running conditions. Secondly, in other study by A. Maiboom et al. [57], conventional HP EGR and "super cooled" HP EGR were compared, in addition HP and LP EGR loops were compared too. Both, the "super cooled" HP EGR and the LP EGR, that presented very low temperature due to the low pressure after the turbine and the intercooler, presented better NOx-PM trade-off. Moreover, the possibility to increase the boost pressure with LP EGR loop that allows the possibility to increase the EGR cooled rates, improved the NOx-PM trade-off in some running conditions and got worse in others. Finally, at higher loads it was 
possible to reduce PM emissions and, consequently, an improvement of NOxPM trade-off with an increment of both, the boost and injection pressure.

Finally, A. Maiboom and X. Tauzia [58] published an experimental study in 2011 based on a strategy used before in large marine diesel engines: the introduction of water in combustion chamber, also known as water-in-diesel emulsion (WDE). The volumetric to fuel ratio was $25.6 \%$. The strategy was tested with and without EGR, specifically HP uncooled EGR. The results without EGR showed that the NOx were reduced significantly and PM emissions were reduced most of times too, up to $94 \%$. Nevertheless, sometimes, at high loads, PM increased due to opposite effects of WDE on production and oxidation of PM. However, when the WDE was used together with EGR strategy, always, both PM and NOx emissions were reduced, hence the PMNOx trade-off improved significantly. On the other hand the application of WDE in automotive engines presented some issues related to cold start, high pressure pumps and the emulsion stability that could be solved with an onboard emulsion fabrication.

\subsubsection{Strategies (HP EGR and LP EGR)}

There are two main EGR strategies: high pressure (HP) and low pressure (LP). They are different strategies, not better or worse, so it depends on the context. In fact, nowadays there are a lot of cars that have both of them. It is very useful because it adapts better to more complex strategies required to achieve the antipollutants standards, increasingly demanding.

So, the development of new and more complex EGR strategies are necessary because of the reduction in emissions requirement, the economic cost of the after-treatment systems and the problems commented before. Studies like Millo et al. in 2012 and Zamboni et al. in 2013 present results about the simultaneous use of HP and LP EGR as an effective combination to reduce NOx emissions and fuel consumption at low and medium speed and load conditions [59,60]. In addition, HP and LP EGR have different consequences on the engine performance depending on the operation point [61] so both are necessary but the use of one loop or the other will depend on the needs. A recent updated study authored by M. Lapuerta et al. in 2018 analyzed deeply the applications 
of LP EGR and HP EGR depending on the needs in a Euro 6 diesel engine equipped with DOC, a lean-NOx trap and DPF [62].

\subsubsection{Advantages and disadvantages}

This study is focused in the HP EGR configuration. On the one hand, HP EGR shows some disadvantages compared to LP EGR [63]. HP EGR reduces NOx emissions but penalizing the fuel consumption and the dispersion of the EGR among cylinders, as it was commented before, a bad EGR distribution affects negatively to NOx-PM trade-off. On the other hand, HP EGR presents some advantages versus LP EGR. HP EGR is faster than LP EGR due to the length of the line, which is closer to the intake manifold. It produces less HC emissions too and its efficiency is higher at cold conditions due to the increase of the temperature [64]. In addition, HP configuration needs less exhaust energy because the compressor operates under lower amount of gas. Moreover, the LP EGR presents troubles related to condensation issues at low ambient temperatures when it mixes with ambient air. In fact, the new requirements are accompanied by new challenges to overcome like the effect of the condensation when EGR mixes with ambient low temperature air. Because of that, this effect was recently studied by J. R. Serrano et al. in 2018 and J. Galindo et al. in 2019 to predict the condensation rate [65] and its effect in the rotor of the compressor [66] respectively. Nevertheless, at low ambient temperature, condensation issues can appear in whole engine and in all its elements, in the HP EGR line for instance as J. M. Luján et al. described in 2019 [67].

\subsubsection{New standards: Low temperatures and transient cycles}

The forecast in emissions legislation, in the way of the Euro 6, is the incorporation of new restrictions at low temperatures and high altitudes [68]. According to the new restrictions $X$. Tauzia et al. presented a detailed study in 2018 [69] related to the effect of cold starting temperatures, between $30^{\circ} \mathrm{C}$ and $90^{\circ} \mathrm{C}$, over the efficiency because of the friction and the heat transfer during the thermal transient, moreover the combustion efficiency decreases due to higher $\mathrm{CO}$ and $\mathrm{HC}$ emissions at low loads. Furthermore, pollutant emissions are highly affected because of the temperature variation of $60^{\circ} \mathrm{C}$ where $\mathrm{CO}, \mathrm{HC}$ and soot evolution is complex although the NOx decrease at low temperatures. Finally, low coolant temperature is more determinant than oil temperature which only 
affects to friction loses, nevertheless it should be considered too. From this point of view, the EGR strategies are very interesting to reduce the pollutant emissions, especially HP EGR to start the engine at low temperatures as J. M. Luján et al. studied in 2018 [70].

The application range of the EGR was adapted to New European Driving Cycle (NEDC) and European emissions standards during decades. The EGR was active only at low speeds and low loads and that was enough to comply the standards. However, since the application of the Euro 6 standard that incorporated more realistic homologation tests like Real Driving Emissions test (RDE) [71], besides lower temperatures mentioned before, studied by J. M. Luján et al. in 2017. In addition to the RDE, other test bench homologation tests were included too with high transient operation conditions, closer to the real working condition than NEDC, like Worldwide harmonized Light vehicles Test Procedures (WLTP) cycles [72], studied by J. Galindo et al. in 2017, and World Harmonized Transient Cycle (WHTC). From this point of view, the EGR strategies must be optimized to adapt itself to these working conditions and comply the legislation [3].

\subsection{Modeling approach}

Computational codes, numerical simulations and modeling tools are widely used in engines research to predict fluid dynamics behavior. From 0D to 3D, including 1D, there is a lot of literature background. This kind of tools are very useful because they are fast, they do not need a complex facility or infrastructure and they are able to calculate variables which are not possible to measure experimentally. These methods have been improved and developed over the years and they can be accurate and reliable when properly applied. Nevertheless, these techniques have their limits and this study explores those limits too.

It is possible classify the different kind of models according to the spatial representation of the physical phenomena they describe, as follows:

- Non-dimensional or zero-dimensional (0D) model: There is not spatial resolution. 
- 1D model: There is spatial resolution in one of the spatial variables, which should be the dominant dimension of the problem.

- Multidimensional models: It could be spatial resolution in two spatial variables, which are called bi-dimensional (2D) models, or it could be spatial resolution in the three spatial variables, 3D models.

The study of the 1D model prediction capability of the EGR transport inside the intake manifold and the dispersion among cylinders is one of the main objectives of this work. From this point of view, it is very interesting the quasi3D modeling, solving 0D or 1D equations but taking into account 3D geometry factors. M. Hernández studied deeply this scope [73].

From the air management point of view, there are different computational methods that are particularly interesting for the compromise in accuracy and computational cost that they offer. These methods can be classified, in chronological and dimensional order, as: Filling and emptying models, wave action models and multidimensional models.

\subsubsection{Filling and emptying models}

The filling and emptying models are commonly used in volumes that are filled and emptied without needing to solve the momentum conservation equations. Instead of that, this method models the momentum conservation among the volumes [73]. This method simulates the mass and energy conservation, allowing the heat exchange with the environment [74]. The elements where this method is employed are usually considered OD elements, so the proper application of this method is restricted to some specific situations and elements, like cylinders. In addition they used to be diagnostic models, quasi-steady and isentropic. The main advantage of this method is its very low computational cost [75].

The filling and emptying model is based on an energy and mass balance and applied when the thermodynamics properties in a system and the intake and the outlet mass flow, connected to the system, are known in a specific moment. Then, the model calculates the properties of the system in the next time step [75]. 


\subsubsection{Wave action models}

The wave action models solve the state equations and the governing equations of mass, energy and momentum under the one-dimensional and unsteady compressible non-homentropic flow criteria.

These models are very useful in engine modeling applications, especially regarding air management, due to the fact that the approximation of the onedimensional simplification to the flow behavior in the intake and the exhaust line of the engine is a very realistic approximation, so they can offer a very fast solution with accurate results. Some of the most important methods are briefly commented below. It is possible to find a detailed explanation in the D. E. Winterbone and R. J Pearson's book titled "Theory of engine manifold design: wave action methods for IC engines" [76] or the M. Hernández's Doctoral Thesis [73].

\subsubsection{Method of the Characteristics}

The origin of the simulation techniques applied to engines emerged in the 1950s with the Method of the Characteristics [77, 78, 79, 80], since it was possible to solve them through graphical methods. The Method of the Characteristics was developed years before by Riemann, at the end of the decade of the 1850s [81]. The application of the graphical method to simulate the gas-dynamics behavior evolved, thanks to the arrival of the computers, to a numerical method in the 1980s [82].

Nevertheless, during the decade of 1970s more methods based on finitedifferences schemes were developed [83, 84], and in the mid 1980s, these methods were imposed over the Method of the Characteristics because the latter produced some issues regarding to the evaluation of the mass conservation, among other reasons [75].

\subsubsection{Conservative centered schemes}

The centered schemes calculate the variables in the center of every cell. One of the most relevant methods is based on the schemes of Lax-Wendroff and it is denominated Lax-Wendroff method [85], with second order accuracy and where the governing equations, written in their conservative form, become to a centered scheme. The Lax-Wendroff method was presented in 1960 by P. Lax 
and B. Wendroff, and it is based on the Taylor series [75], but that implied to solving a Jacobian matrix. Therefore, during the 1960's, R. D. Richtmeyer and K. W. Morton proposed a two-step approach to avoid the resolution of the Jacobian matrix: the two-step Lax-Wendroff method [86, 87], which gave rise to the predictor-corrector methods. Later, around 1970, R. W. MacCormack developed the MacCormack method [88, 89], that also consist on a two-step predictor-corrector method. Both of them, two-step Lax-Wendroff and MacCormack, keep the second order accuracy. Finally, in 1974, A. Lerat and R. Peyret worked on a general two-step predictor-corrector method based on a scheme with two parameters: $\alpha$ and $\beta$. It was denominated the $W_{\beta}^{\alpha}$ classification [90]. When the value of both parameters $\alpha$ and $\beta$ are 0.5 , the scheme is equivalent to two-step Lax-Wendroff scheme, when one of the parameters, $\alpha$ or $\beta$, is 0 and the other one is 1 , the scheme corresponds to the MacCormack method. In the linear case where the Jacobian matrix is constant, all the schemes are like Lax-Wendroff schemes [76]. Nevertheless, in 1975, Lerat and Peyret [91] recognized that their approximation was not able to avoid the overshoots in the surfaces in non-linear cases, although the $\alpha$ and $\beta$ values were optimized for the particular cases. In any case, as it was commented before, some of this kind of methods were imposed over the Characteristics' Method in the mid 1980s.

\subsubsection{Upwind schemes and Riemann solvers}

The centered schemes do not take into account the physical direction of the fluid in the discretization, they are symmetrical. On the other hand, the upwind schemes consider the direction of the propagation waves [73].

R. Courant, E. Isaacson and M. Rees developed the first upwind scheme in 1952 [92], it was a first order accuracy method, but later other upwind schemes were developed in the form of Riemann solvers, with a higher accuracy order. One of the most relevant was the Godunov's method, which is the origin of many modern schemes also known as reconstruction-evolution schemes [73].

The Godunov's method was proposed by S.K. Godunov in 1959 [93]. It is a finite-volume method that initially solved the Riemann problem analytically, although approximate solutions with lower computational cost were proposed by other authors later. The Godunov's method uses the information of the characteristic lines in a conservative scheme. The Godunov's scheme, as the 
Godunov's scheme family methods developed later, were first-order schemes [73]. It is possible to define the Godunov's method as a three-step method where, in the first step, the initial discretized set of data in the solution domain could be replaced by an approximation set of data that keep constant in each cell. As a result, a piecewise-constant data with discontinuities appears at each cell interface, $x_{i \pm 1 / 2}$, like it is possible to see in Figure 2.2. The second step consist of calculating the inter-cell fluxes that are become in a sequence local Riemann problem, one for each cell, solved analytically. Finally, in the third step, a new constant set of data for each cell is calculated for the next time step, creating in this way a new set of local Riemann problems to repeat the process $[73,76]$.

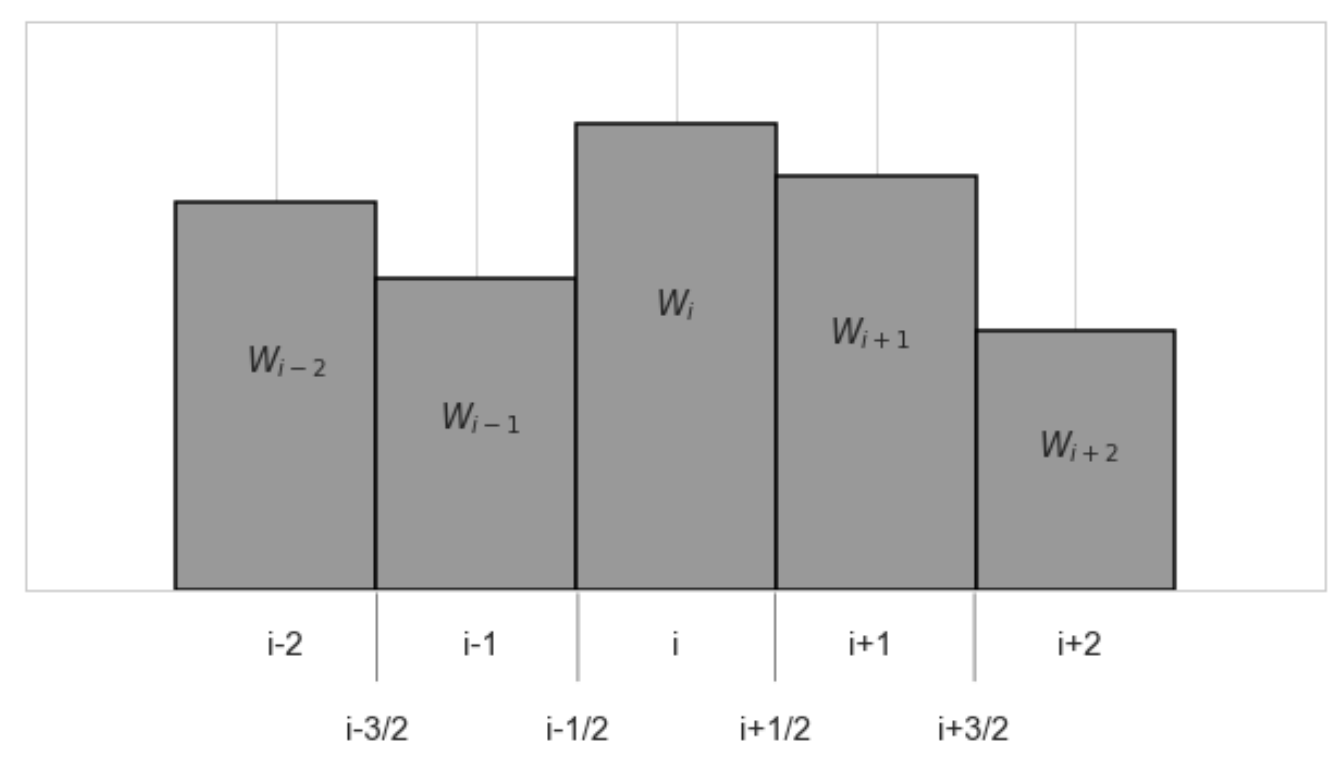

Figure 2.2. Constant data in each cell in a Godunov's scheme

Godunov's method was the basis from which many other methods were developed. It was the case of the "Roe's approximate Riemann solver", presented by P. L. Roe in 1981 [94]. Roe suggested that it was not necessary to solve the Riemann problem by an analytic solution, i. e., it is not necessary an exact solution. On the contrary an approximate solution in the second step of the Godunov's method was enough in order to speed up the calculation time without penalizing the accuracy. The Roe's Riemann solver was a success and, 
after that, other authors proposed alternative methods trying to reduce the computational cost.

In that way, in 1983, A. Harten, P.D. Lax and B. van Leer presented the "HartenLax-van Leer (HLL) Riemann Solver" [95]. The HLL Riemann Solver consists of the employment of a simplified wave structure of the Riemann problem and solve it by an integral evaluation of the conservation laws as a direct approximation on the inter-cell numerical flux $[73,76]$. This is a very robust numerical method that offers a very efficient inter-cell flux calculation. On the other hand, the simplification ignores the contact surface and, as a consequence, the results in the surface region are diffusive [73]. Later, in 1994, Toro et al. proposed an improvement of the HLL method, called "HLLC Riemann Solver" [96] that adds a third wave, that it is in fact a contact surface wave, located between the two waves considered by the HLL Riemann Solver. In this way the HLLC Riemann Solver keeps the robustness and efficiency of the HLL Riemann Solver but it additionally improves the surface region calculated results. Consequently, the results offered by the HLLC Riemann Solver are similar to Godunov's method results, but the application of an approximate resolution instead of the analytic resolution reduce considerably the computational cost $[73,76]$.

\subsubsection{High resolution schemes}

The Godunov's scheme and the methods developed based on it are, all of them, first-order accuracy methods. The conservative centered schemes are secondorder accuracy, but they did not take into account the physical direction of the fluid, and they generate spurious oscillation at discontinuities as a consequence [76]. On the other hand, the Riemann Solvers based on Godunov's scheme are robust and efficient methods that do not generate oscillatory solution and, in addition, they take into account the physics of propagation phenomena. Therefore, the development of new higher-order accuracy methods based on Godunov's scheme family could lead to methods without oscillating solutions.

Unfortunately, the schemes extended to higher-order accuracy in a straightforward manner, offered similar spurious oscillations than conservative centered schemes. This problem was alerted by Godunov in his "Godunov's Theorem" [93], which said that the linear numerical schemes to solve partial 
differential equations, that were monotone schemes due to they did not generate new extrema, could not be higher-order accuracy than first-order. In his theorem, Godunov demonstrated that the resulting equation of a monotone second-order accuracy scheme, developed from a linear numerical scheme, violated the Cauchy inequality. Therefore, such scheme did not exist was concluded.

However, between 1973 and 1975, B. van Leer [97, 98], J. P. Boris and D. L. Book [99] and D. L. Book et al. [100] proposed to avoid the Godunov's Theorem using non-linear difference scheme instead of linear numerical schemes. The idea was used high-order accuracy schemes rising locally the numerical dissipation in the regions were present discontinuities to avoid the development of spurious oscillations [76]. This approach lead to the "High-resolution schemes" that take a higher computational cost but they are able to avoid the oscillations as compensation. Some of the most popular are the Total Variation Diminution (TVD), the Flux Corrected Transport (FCT) or the Monotonic upstreamcentered scheme for conservation laws (MUSCL).

\subsubsection{Multidimensional models}

The multidimensional models, commonly denominated Computational Fluid Dynamics (CFD) methods too, consist of applying of techniques like finitedifferences or finite-volume [74] to solve the equations in its multidimensional form (usually 3D). They offer high accuracy in the whole domain. However, these methods present a high computational cost, therefore they are not normally used over the complete engine system, including the intake and the exhaust line. On the contrary, they are commonly applied locally, on specific devices especially susceptible to present three-dimensional flow, like the manifolds, and they are normally employed in the final stages of the design process [73]. Nevertheless, in the proportion with the computational power increases, they are more commonly used.

However, the quasi-3D methods were been developed the last years [101, 102] offer high resolution to multidimensional features but with lower computational cost than CFD or 3D methods. The quasi-3D methods are being commonly used in commercial codes [73], for specific complex devices where the real flow obey multidimensional conditions [103] and even as the core of the 
whole computation $[104,105]$. In this way it is possible that the model obtains the benefits of the 1D model related with the low computational cost when it is possible to presume that the behavior of the flow is almost $1 \mathrm{D}$, and it obtains the higher precision of the 3D model when it is required [73]. Hence, the development of the quasi-3D methods has a high potential in the engine modeling application.

\subsection{HP EGR dispersion}

The effect of the HP EGR dispersion among cylinders on smoke and NOx emissions in automotive diesel engines is a topic to explore in depth. Long time ago emissions troubles related to unequal distribution among cylinders or bad mixing of the HP EGR were widely known and strategies to minimize that effect were developed by R. M. Siewert et al. and W. P. Partridge et al. in 2001 and 2002 respectively [14, 106]. Furthermore in 2009 Payri et al. published a study comparing a LP EGR and HP EGR and their influence on PM-NOx trade-off. The analysis conclude that the HP presented worse PM-NOx trade-off due to the bad distribution of the EGR among cylinders [107]. The same year, A. Maiboom et al. performed a study about the increment of the NOx and PM emissions as consequences of an unequal cylinder-to-cylinder EGR distribution and increasing the EGR rate [15]. The study concluded that the unequal distribution of the EGR among cylinders presented an increment of the NOx and PM emissions, and that this effect was particularly important at high EGR rates.

Regarding the EGR dispersion modeling, in 2001 R. M. Siewert et al. performed an investigation combining CFD and experimental tools [14] where two manifolds were developed to reduce the EGR dispersion and CFD analysis to understand the causes of the high dispersion. Later, in 2013 Lakhlani et al. [16] studied the cylinder to cylinder HP EGR dispersion combining experimental and, 1D and CFD, modelling tools in light-duty tracks and the effect on NOxPM trade-off. The study compares the same operation points with and without HP EGR mixture. The study concludes that the effect of the dispersion in PM and NOx trade-off is significant in partial and high loads; however, the impact at low loads remains unclear. Moreover, the EGR mixture has a negligible effect on combustion. In 2015 P. Dimitriou et al. [108] performed a thorough study of 
the geometry in the cylinder to cylinder dispersion, since they analyzed ten different configurations combining $1 \mathrm{D}$ and 3D modeling. The study was focused in the parameters and effects that enhance the air-EGR mixing behavior like turbulence, Venturi, air-EGR contact area and the size and number of injection ports of EGR. The study concluded that velocity, turbulence, Venturi effect and a lot of small ports in the mixer improve the air-EGR mixing. Finally, an experimental study developed by Luján et al. in 2015 [109] demonstrated that the reduction of EGR dispersion is related with a significant reduction of NOx emissions and the effects on fuel consumption are negligible. 



\section{Chapter 2 Bibliography}

[3] J. M. Luján, H. Climent, F. Aranu, and J. Miguel-García. “Analysis of low pressure exhaust gases recirculation control in transient operation of automotive diesel engines". Applied Thermal Engineering 137 (2018), pp. 184192. URL: https://doi.org/10.1016/j.applthermaleng.2018.03.085 (cit. on pp. xvii, $33,59)$.

[8] N. Ladommatos, R. Balian, R. Horrocks, and L. Cooper. "The effect of exhaust gas recirculation on combustion and NOx emissions in a high-speed direct-injection diesel engine". Society of Automotive Engineers, SAE paper 960840, 1996 (cit. on pp. 5, 30).

[9] N. Ladommatos, R. Balian, R. Horrocks, and L. Cooper. "The effect of exhaust gas recirculation on soot formation in a high-speed direct-injection diesel engine". Society of Automotive Engineers, SAE paper 960841, 1996 (cit. on pp. $5,30,124)$.

[10] N. Ladommatos, S. M. Abdelhalim, and H. Zhao. "Control of oxides of nitrogen from diesel engines using diluents while minimizing the impact on particulate pollutants". Applied Thermal Engineering 18 (11) (1998), pp. 963980. URL: https://doi.org/10.1016/S1359-4311(98)00031-3 (cit. on pp. 5, 30, 124).

[11] A. Maiboom, X. Tauzia, and J-F. Hétet. "Experimental study of various effects of exhaust gas recirculation (EGR) on combustion and emissions of an automotive direct injection diesel engines". Energy 33 (2008), pp. 22-34. DOI: 10.1016/j.energy.2007.08.010 (cit. on pp. 5, 30, 124).

[13] D. R. Tree and K. I. Svensson. "Soot processes in compression ignition engines". Progress in Energy and Combustion Science 33 (3) (2007), pp. 272-309. URL: https://doi.org/10.1016/j.pecs.2006.03.002 (cit. on pp. 5, 27, 28, 125, 126).

[14] R. M. Siewert, R. B. Krieger, M. S. Huebler, P. C. Baruah, B. Khalighi, and M. Wesslau. "Modifying and Intake Manifold to Improve Cylinder-to-Cylinder EGR Distribution in a DI Diesel Engine Using Combined CFD and Engine Experiments". 2001 SAE Technical Paper 2001-01-3685. URL: http://dx.doi.org/10.4271/2001-01-3685 (cit. on pp. 5, 40, 67, 187). 
[15] A. Maiboom, X. Tauzia, and J-F. Hétet. "Influence of EGR unequal distribution from cylinder to cylinder on NOx-PM trade-off of a HSDI automotive Diesel engine". Applied Thermal Engineering 29 (2009), pp. 20432050. DOI: 10.1016/j.applthermaleng.2008.10.017 (cit. on pp. 5, 40, 67, 187).

[16] H. Lakhlani, J. Barman, K. Rajput, and A. Goswami. "Experimental Study of EGR Mixture Design and its Influence on EGR Distribution Across the Cylinder for NOx-PM Tradeoff". 2013 SAE Int. DOI: 10.4271/2013-01-2743 (cit. on pp. 5,40$)$.

[17] C. C. Patterson. "Age of meteorites and the earth". Geochimica et Cosmochimica Acta 10 (4) (1956), pp. 230-237. URL: https://doi.org/10.1016/0016-7037(56)90036-9 (cit. on p. 16).

[18] M. Tatsumoto and C. C. Patterson. "Concentrations of common lead in some Atlantic and Mediterranean waters and in snow". Nature 199 (1963), pp. 350-352. URL: https://doi.org/10.1038/199350a0 (cit. on p. 17).

[19] C. C. Patterson. "Contaminated and Natural Lead Environments of Man". Archives of Environmental Health: An International Journal 11 (3) (1965), pp. 344-360. URL: https://doi.org/10.1080/00039896.1965.10664229 (cit. on p. 17).

[20] R. A. Kehoe. "Contaminated and Natural Lead Environments of Man". Archives of Environmental Health: An International Journal 11 (5) (1965), pp. 736-739. URL: https://doi.org/10.1080/00039896.1965.10664290 (cit. on p. 18).

[21] H. L. Needleman. “Clair Patterson and Robert Kehoe: Two Views of Lead Toxicity". Environmental Research 78 (2) (1998), pp. 79-85. URL: https://doi.org/10.1006/enrs.1997.3807 (cit. on p. 18).

[22] "EPA Sets New National Air Pollution Standard for Lead". EPA press release, 1978. https://archive.epa.gov/epa/aboutepa/epa-sets-new-national-airpollution-standard-lead.html (cit. on p. 18).

[23] J. L. Pirkle, D. J. Brody, E. W. Gunter, R. A. Kramer, D. C. Paschal, K. M. Flegal, and T. D. Matte. "The Decline in Blood Lead Levels in the United States: The National Health and Nutrition Examination Surveys (NHANES)". Journal of the American Medical Association 272 (4) (1994), pp. 284-291. DOI: 10.1001/jama.1994.03520040046039 (cit. on p. 19). 
[24] V. M. Thomas. "The Elimination of Lead in Gasoline". Annual Review of Energy and the Environment 20 (1) (1995), pp. 301-324. DOI: 10.1146/annurev.eg.20.110195.001505 (cit. on p. 19).

[25] J. L. Pirkle, J. Schwartz, J. R. Landis, and W. R. Harlan. “The relationship between blood lead levels and blood pressure and its cardiovascular risk implications". American Journal of Epidemiology 121 (2) (1985), pp. 246-258. URL: https://doi.org/10.1093/oxfordjournals.aje.a113995 (cit. on p. 19).

[26] A. L. Nichols. "Lead in gasoline". Economic Analyses at EPA: Assessing Regulatory Impact, edited by Richard D. Morgenstern. Washington DC: Resources for the Future 49 (4) (1997), pp. 49-86 (cit. on p. 19).

[27] R. G. Newell and K. Rogers. "The U.S. Experience with the Phasedown of Lead in Gasoline". Resources for the Future (2003) (cit. on p. 19).

[28] European Environment Agency. "Air quality in Europe - 2016 Report". EEA Report No 28/2016 (2016). ISBN 978-92-9213-847-9, ISSN 1977-8449. DOI: 10.2800/80982 (cit. on p. 23).

[29] European Environment Agency. "Air quality in Europe - 2017 Report". EEA Report No 13/2017 (2017). ISBN 978-92-9213-921-6, ISSN 1977-8449. DOI: $10.2800 / 850018$ (cit. on p. 23).

[30] European Environment Agency. "Air quality in Europe - 2018 Report". EEA Report No 12/2018 (2018). ISBN 978-92-9213-989-6, ISSN 1977-8449. DOI: $10.2800 / 777411$ (cit. on p. 23).

[31] European Environment Agency. "Air quality in Europe - 2019 Report". EEA Report No 10/2019 (2019). ISBN 978-92-9480-088-6, ISSN 1977-8449. DOI: 10.2800/822355 (cit. on p. 23).

[32] Y. Ogen. "Assessing nitrogen dioxide $\left(\mathrm{NO}_{2}\right)$ levels as a contributing factor to coronavirus (COVID-19) fatality". Science of the Total Environment 726 (2020) 138605. URL: https://doi.org/10.1016/j.scitotenv.2020.138605 (cit. on p. 25).

[33] E. Conticini, B. Frediani, and D. Caro. "Can atmospheric pollution be considered a co-factor in extremely high level of SARS-CoV-2 lethality in 
Northern Italy?". Environmental Pollution, (2020) 114465. DOI: 10.1016/j.envpol.2020.114465 (cit. on p. 25).

[34] K. M. Nichols, L. M. Thompson, and H. J. Empie. “A review of NOx formation mechanisms in recovery furnaces". Tappi Journal 76 (1) (1993) (cit. on p. 26).

[35] A. Moratal. "Experimental analysis of thermal management influence on performance and emissions in diesel engines at low ambient temperature". Doctoral Thesis (2018) (cit. on p. 26).

[36] J. Zeldovich. "The Oxidation of Nitrogen in Combustion and Explosions". Acta Physiochimica U.R.S.S. 21 (4) (1946), pp. 577-628 (cit. on p. 26).

[37] G. A. Lavoie, J. B. Heywood, and J. C. Keck. “Experimental and Theoretical Study of Nitric Oxide Formation in Internal Combustion Engines". Combustion Science and Technology 1 (4) (1970), pp. 313-326. DOI: 10.1080/00102206908952211 (cit. on p. 26).

[38] I. M. Campbell and B. A. Thrush. "Reactivity of hydrogen to atomic nitrogen and atomic oxygen". Transactions of the Faraday Society 64 (1968), pp. 1265-1274. URL https://doi.org/10.1039/TF9686401265 (cit. on p. 26).

[39] C. P. Fenimore. "Formation of nitric oxide in premixed hydrocarbon flames". In: Symposium (International) on Combustion 13 (1) (1971), pp. 373380. URL: https://doi.org/10.1016/S0082-0784(71)80040-1 (cit. on p. 26).

[40] K. Schofield. "An evaluation of kinetic rate data for reactions of neutrals of atmospheric interest". Planetary and Space Science 15 (4) (1967), pp. 643-670. URL: https://doi.org/10.1016/0032-0633(67)90038-4 (cit. on p. 26).

[41] M. Lapuerta and R. Ballesteros. "Emisiones contaminantes". In "Motores de combustión interna alternativos". (2011), pp. 415-444. Universitat Politècnica de València: F. Payri and J.M. Desantes (cit. on pp. 27, 28).

[42] O. I. Smith. "Fundamentals of soot formation in flames with application to diesel engine particulate emissions". Progress in Energy and Combustion Science 7 (4) (1981), pp. 275-291. URL: https://doi.org/10.1016/03601285(81)90002-2 (cit. on p. 27). 
[43] B. S. Haynes and H. Gg. Wagner. "Soot formation". Progress in Energy and Combustion Science 7 (4) (1981), pp. 229-273. URL: https://doi.org/10.1016/03601285(81)90001-0 (cit. on p. 27).

[44] I. Glassman. “Combustion”. San Diego: Academic Press; 1996 (cit. on p. 28).

[45] M. Zheng, G. T. Reader, and J. G. Hawley. “Diesel engine exhaust gas recirculation - a review on advanced and novel concepts". Energy Conversion and Management 45 (2004), pp. 883-900 (cit. on p. 29).

[46] D. Agarwal, S. K. Singh, and A. K. Agarwal. "Effect of Exhaust Gas Recirculation (EGR) on performance, emissions, deposits, and durability of a constant speed compression ignition engine". Applied Energy 88 (2011), pp. 2900-2907 (cit. on p. 29).

[47] S. Bai, J. Han, M. Liu, S. Qin, G. Wang, and G-x. Li. “Experimental investigation of exhaust thermal management on NOx emissions of heavy-duty diesel engine under the world Harmonized transient cycle (WHTC)". Applied Thermal Engineering 142 (2018), pp. 421-432. URL: https://doi.org/10.1016/j.applthermaleng.2018.07.042 (cit. on p. 29).

[48] B. Guan, R. Zan, H. Lin, and Z. Huang. "Review of state of the art technologies catalytic reduction of NOx from diesel engine exhaust". Applied Thermal Engineering 66 (1-2) (2014), pp. 395-414. URL: https://doi.org/10.1016/j.applthermaleng.2014.02.021 (cit. on p. 29).

[49] S. Sadashiva Prabhu, N. S. Nayak, N. Kapilan, and V. Hindasageri. “An experimental and numerical study on effects of exhaust gas temperature and flow rate on deposit formation in Urea-Selective Catalytic Reduction (SCR) system of modern automobiles". Applied Thermal Engineering 111 (2017), pp. 1211-1231. URL: https://doi.org/10.1016/j.applthermaleng.2016.09.134 (cit. on p. 29).

[50] N. Ladommatos, S. M. Abdelhalim, H. Zhao, and Z. Hu. "The dilution, chemical, and thermal effects of exhaust gas recirculation on diesel engine emissions - Part 1: Effect of reducing inlet charge oxygen". SAE paper 961165, 1996 (cit. on p. 30). 
[51] N. Ladommatos, S. M. Abdelhalim, H. Zhao, and Z. Hu. "The dilution, chemical, and thermal effects of exhaust gas recirculation on diesel engine emissions - Part 2: Effects of carbon dioxide". SAE paper 961167, 1996 (cit. on p. 30).

[52] N. Ladommatos, S. M. Abdelhalim, H. Zhao, and Z. Hu. "The dilution, chemical, and thermal effects of exhaust gas recirculation on diesel engine emissions - Part 3: Effects of water vapor". SAE paper 971659, 1997 (cit. on p. 30).

[53] N. Ladommatos, S. M. Abdelhalim, H. Zhao, and Z. Hu. “The dilution, chemical, and thermal effects of exhaust gas recirculation on diesel engine emissions - Part 4: Effects of carbon dioxide and water vapor". SAE paper 971660, 1997 (cit. on p. 30).

[54] C. A. Van Roekel, D. T. Montgomery, J. Singh, and D. B. Olsen. “Evaluating dedicated exhaust gas recirculation on a stoichiometric industrial natural gas engine". International Journal of Engine Research (2019). https://doi.org/10.1177/1468087419864733 (cit. on p. 30).

[55] R. P. Wilson, E. B. Muir, and F. A. Pellicciotti. "Emissions Study of A SingleCylinder Diesel Engine". SAE Transactions 740123, 83 (1974), pp. 612-632 (cit. on p. 30).

[56] N. Ladommatos, S. M. Abdelhalim, and H. Zhao. "The effects of exhaust gas recirculation on diesel combustion and emissions". International Journal of Engine Research 1 (1) (2000), pp. 107-126. URL: https://doi.org/10.1243/1468087001545290 (cit. on p. 30).

[57] A. Maiboom, X. Tauzia, and J.-F. Hétet. "Influence of high rates of supplemental cooled EGR on NOx and PM emissions of an automotive HSDI diesel engine using an LP EGR loop". International Journal of Engine Research 32 (15) (2008), pp. 1383-1398. DOI: 10.1002/er.1455 (cit. on p. 30).

[58] A. Maiboom and X. Tauzia. “NOx and PM emissions reduction on an automotive HSDI Diesel engine with water-in-diesel emulsion and EGR: An experimental study". Fuel 90 (11) (2011), pp. 3179-3192. https://doi.org/10.1016/j.fuel.2011.06.014 (cit. on pp. 30, 31). 
[59] F. Millo, P. F. Giacominetto, and M. G. Bernardi. "Analysis of different exhaust gas recirculation architetures for passenger car Diesel engines". Applied Energy 98 (2012), pp. 79-91. URL: https://doi.org/10.1016/j.apenergy.2012.02.081 (cit. on p. 31).

[60] G. Zamboni and M. Capobianco. "Influence of high and low pressure and VGT control on in-cylinder pressure diagrams and rate of heat release in an automotive turbocharged diesel engine". Applied Thermal Engineering 51 (12) (2013), pp. 586-596. URL: https://doi.org/10.1016/j.applthermaleng.2012.09.040 (cit. on p. 31).

[61] K. Shen, F. Li, Z. Zhang, Y. Sun, and C. Yin. "Effects of LP and HP cooled EGR on performance and emissions in turbocharged GDI engine". Applied Thermal Engineering 125 (2017), pp. 746-755. URL: https://doi.org/10.1016/j.applthermaleng.2017.07.064 (cit. on pp. 31, 187).

[62] M. Lapuerta, Á. Ramos, D. Fernández-Rodríguez, and I. González-García. "High-pressure versus low-pressure exhaust gas recirculation in a Euro 6 diesel engine with lean-NOx trap: Effectiveness to reduce NOx emissions". International Journal of Engine Research 20 (1) (2018), pp. 155-163. URL: https://doi.org/10.1177/1468087418817447 (cit. on p. 32).

[63] J. Thangaraja and C. Kannan. "Effect of exhaust gas recirculation on advanced diésel combustion and alternate fuels - A review". Applied Energy 180 (2016), pp. 169-184. URL: https://doi.org/10.1016/j.apenergy.2016.07.096 (cit. on p. 32).

[64] J. M. Luján, C. Guardiola, B. Pla, and A. Reig. "Switching strategy between HP (high pressure) - and LPEGR (low pressure exhaust gas recirculation) systems for reduced fuel consumption and emissions". Energy 90 (2015), pp. 1790-1798. DOI: 10.1016/j.energy.2015.06.138 (cit. on p. 32).

[65] J. R. Serrano, P. Piqueras, R. Navarro, D. Tarí, and C. M. Meano. “Development and verification of an in-flow water condensation model for 3DCFD simulations of humid air streams mixing". Computers and Fluids 167 (2018), pp. 158-165. DOI: 10.1016/j.compfluid.2018.02.032 (cit. on p. 32). 
[66] J. Galindo, P. Piqueras, R. Navarro, D. Tarí, and C. M. Meano. “Validation and sensitivity analysis of an in-flow water condensation model for 3D-CFD simulations of humid air streams mixing". International Journal of Thermal Sciences 136 (2019), pp. 410-419. DOI: 10.1016/j.ijthermalsci.2018.10.043 (cit. on p. 32).

[67] J. M. Luján, V. Dolz, J. Monsalve-Serrano, and M. A. Bernal Maldonado, "High-pressure exhaust gas recirculation line condensation model of an internal combustion diesel engine operating at cold conditions". International Journal of Engine Research (2019). URL: https://doi.org/10.1177/1468087419868026 (cit. on p. 32).

[68] V. Bermúdez, J. R. Serrano, P. Piqueras, J. Gómez, and S. Bender. “Analysis of the role of altitude on diesel engine performance and emissions using an atmosphere simulator". International Journal of Engine Research 18 (1-2) (2017), pp. 105-117. DOI: 10.1177/1468087416679569 (cit. on p. 32).

[69] X. Tauzia, A. Maiboom, H. Karaky, and P. Chesse. "Experimental analysis of the influence of coolant and oil temperature on combustion and emissions in an automotive diesel engine" International Journal of Engine Research 20 (2) (2018), pp. 247-260. DOI: 10.1177/1468087417749391 (cit. on p. 32).

[70] J. M. Luján, H. Climent, S. Ruiz, and A. Moratal. “Influence of ambient temperature on diesel engine raw pollutants and fuel consumption in different driving cycles". International Journal of Engine Research 20 (8-9) (2019), pp. 877-888. DOI: 10.1177/1468087418792353 (cit. on p. 33).

[71] J. M. Luján, V. Dolz, J. Monsalve-Serrano, and J. A. López-Cascant. “New anti-pollution regulation for Euro 6 diesel vehicles". Técnica Industrial 318 (2017), pp. 28-33. DOI:10.23800/9939 (cit. on p. 33).

[72] J. Galindo, H. Climent, O. Varnier, and C. Patil. “Effect of boosting system architecture and thermomechanical limits on diesel engine performance: Part II-transient operation". International Journal of Engine Research 19 (8) (2017), pp. 873-885. DOI: 10.1177/1468087417732264 (cit. on p. 33). 
[73] M. Hernández. "A non-linear quasi-3D model for air management modelling in engines". Doctoral Thesis (2018) (cit. on pp. 34, 35, 36, 37, 38, 39, $40,78,187)$.

[74] J. Galindo and J. J Hernández. "Modelado de motores". In "Motores de combustión interna alternativos" (2011), pp. 745-797. Universitat Politècnica de València: F. Payri and J.M. Desantes (cit. on pp. 34, 39).

[75] H. Climent. "Contribución al modelado unidimensional de motores de dos tiempos de pequeña cilindrada". Doctoral Thesis (2002) (cit. on pp. 34, 35, 36).

[76] D. E. Winterbone and R. J. Pearson. "Theory of engine manifold design: wave action methods for IC engines". Wiley-Blackwell (2000) (cit. on pp. 35, 36, $37,38,39,74)$.

[77] E. Jenny. "Unidimensional transient flow with consideration of friction, heat transfer and change of section". Brown Boveri Review 37 (11) (1950), pp. 447-461 (cit. on p. 35).

[78] F. Wallace and G. Boxer. "Wave action in diffusers for exhaust-pipe systems, with special reference to the scavenging of two-stroke engines". Proceedings of the type of Mechanical Engineers 170 (1) (1956), pp. 1131-1156 (cit. on p. 35).

[79] R. Benson. "The Effect of Excess Scavenge Air on the Pressure Drop in the Cylinder of a Two-Stroke Cycle Engine During Exhaust Blow down". The Aeronautical Journal 59 (539) (1955), pp. 773-778 (cit. on p. 35).

[80] R. Benson and W. Woods. "Wave action in the exhaust system of a supercharged two-stroke-engine model". International Journal of Mechanical Sciences 1 (2-3) (1960), pp. 253-281 (cit. on p. 35).

[81] B. Riemann et al. "Über die Fortpflanzung ebener Luftwellen von endlicher Schwingungsweite". Verlag der Dieterichschen Buchhandlung, 1860 (cit. on p. 35).

[82] R. S. Benson. “Thermodynamics and Gas Dynamics of Internal Combustion Engines". Cambridge University Press, 1982 (cit. on p. 35). 
[83] G. Zehnder. "Calculating gas flow in pressure-wave machines". Brown Boveri Review 58 (4-5) (1971), pp. 172-176 (cit. on p. 35).

[84] H. Dwyer, R. Allen, M. Ward, D. Karnopp, and D. Margolis. "Shock capturing finite difference methods for unsteady gas transfer". In: $7^{\text {th }}$ Fluid and PlasmaDynamics Conference (1974), p. 521 (cit. on p. 35).

[85] P. Lax and B. Wendroff. "Systems of conservation laws". Communications on Pure and Applied mathematics 13 (2) (1960), pp. 217-237 (cit. on p. 35).

[86] R. D. Richtmyer. "A survey of difference methods for non-steady fluid dynamics". National Center for Atmospheric Research 63 (1963) (cit. on p. 36).

[87] R. D. Richtmyer and K. W. Morton. “Difference methods for initial value problems". Wiley-Interscience, New York, 2nd ed. (1967) (cit. on p. 36).

[88] R. W. MacCormack. "The effect of viscosity in hypervelocity impact cratering". Frontiers of Computational Fluid Dynamics (1969), pp. 27-44 (cit. on p. 36).

[89] R. W. MacCormack. "Numerical solution of the interaction of a shock wave with a laminar boundary layer". Proceedings of the Second International Conference on Numerical Methods in Fluid Dynamics, Lecture Notes in Physics, 8 (1971), pp. 151-163. (Springer, Berlin/Heidelberg). URL: https://doi.org/10.1007/3-540-05407-3_24 (cit. on p. 36).

[90] A. Lerat and R. Peyret. "Non-centred schemes and shock propagation problems". Computers and fluids (1974), pp. 35-52 (cit. on p. 36).

[91] A. Lerat and R. Peyret. "The problem of spurious oscillations in the numerical solution of the equations of gas dynamics". Proceedings of the Fourth International Conference on Numerical Methods in Fluid Dynamics (1975), pp. 251-256. (Springer, Berlin/Heidelberg) (cit. on p. 36).

[92] R. Courant, E. Isaacson, and M. Rees. “On the solution of nonlinear hyperbolic differential equations by finite differences". Communications on Pure and Applied Mathematics 5 (3) (1952), pp. 243-255 (cit. on p. 36). 
[93] S. K. Godunov. "A difference method for numerical calculation of discontinuous solutions of the equations of hydrodynamics". Matematicheskii Sbornik 89 (3) (1959), pp. 271-306 (cit. on pp. 36, 38).

[94] P. L. Roe. "Approximate Riemann solvers, parameter vectors, and difference schemes". Journal of computational physics 43 (2) (1981), pp. 357372 (cit. on p. 37).

[95] A. Harten, P. D. Lax, and B. v. Leer. "On upstream differencing and Godunov-type schemes for hyperbolic conservation laws". SIAM review 25 (1) (1983), pp. 35-61 (cit. on p. 38).

[96] E. F. Toro, M. Spruce, and W. Speares. "Restoration of the contact surface in the HLL-Riemann solver". Shock Waves 4 (1) (1994), pp. 25-34 (cit. on p. 38).

[97] B. van Leer. "Towards the Ultimate Conservative Difference Scheme I. The Quest of Monotonicity". Lecture Notes in Physics 18 (1973), pp. 163-168. DOI: 10.1007/BFb0118673 (cit. on p. 39).

[98] B. van Leer. "Towards the Ultimate Conservative Difference Scheme. II. Monotonicity and Conservation Combined in a Second-order Scheme". Journal of Computational Physics 14 (4) (1974), pp. 361-370. DOI: 10.1016/00219991(74)90019-9 (cit. on p. 39).

[99] J. P. Boris and D. L. Book. "Flux-corrected transport. I. SHASTA, a fluid transport algorithm that works". Journal of Computational Physics 11 (1) (1973), pp. 38-69. URL: https://doi.org/10.1016/0021-9991(73)90147-2 (cit. on p. 39).

[100] D. L. Book, J. P. Boris, and K. Hain. "Flux-corrected transport II: Generalizations of the method". Journal of Computational Physics 18 (3) (1975), pp. 248-283. URL: https://doi.org/10.1016/0021-9991(75)90002-9 (cit. on p. 39).

[101] G. Montenegro, A. Onorati, and A. Della Torre. "The prediction of silencer acoustical performances by 1D, 1D-3D and quasi-3D non-linear approaches". Computers \& Fluids 71 (2013), pp. 208-223. DOI: 10.1016/j.compfluid.2012.10.016 (cit. on p. 39). 
[102] A. J. Torregrosa, A. Broatch, F. J. Arnau, and M. Hernández. “A non-linear quasi-3D model with Flux-Corrected-Transport for engine gas-exchange modelling". Journal of Computational and Applied Mathematics 291 (2016), pp. 103-111. DOI: 10.1016/j.cam.2015.03.034 (cit. on pp. 39, 78, 187).

[103] G. Montenegro, A. Della Torre, A. Onorati, R. Fairbrother, and A. Dolinar. "Development and application of 3D generic cells to the acoustic modelling of exhaust systems". SAE Technical Paper, (2011), 2011-01-1526 (cit. on p. 39).

[104] T. Morel, J. Silvestri, K-A. Goerg, and R. Jebasinski. “Modeling of engine exhaust acoustics". SAE Technical Paper, (1999), 1999-01-1665 (cit. on p. 40).

[105] S. M. Sapsford, V. C. Richards, D. R. Amlee, T. Morel, and M. T. Chappell. "Exhaust system evaluation and design by non-linear modeling". SAE Technical Paper, (1992), 920686 (cit. on p. 40).

[106] W. P. Partridge, S. A. Lewis, M. J. Ruth, G. G. Muntean, R. C. Smith, and J. H. Stang. "Resolving EGR Distribution and Mixing". SAE Technical Paper, (2002), 2002-01-2882. URL: http://dx.doi.org/10.4271/2002-01-2882 (cit. on pp. 40, $67,187)$.

[107] F. Payri, J. M. Luján, H. Climent, and B. Pla. “Effects on the intake charge distribution in HSDI engines". SAE Technical Paper, (2010), 2010-01-1119. URL: http://dx.doi.org/10.4271/2010-01-1119 (cit. on p. 40).

[108] P. Dimitriou, R. Burke, C. Copeland, and S. Akehurst. "Study on the Effects of EGR Supply Configuration on Cylinder-to-Cylinder Dispersion and Engine Performance Using 1D-3D Co-Simulation". SAE Int. (2015) (cit. on p. 40).

[109] J. M. Luján, H. Climent, B. Pla, M. E. Rivas-Perea, N-Y François, J. BorgesAlejo, and Z. Soukeur. "Exhaust gas recirculation dispersion analysis using incylinder pressure measurements in automotive diesel engines". Applied Thermal Engineering 89 (2015), pp. 459-468. URL: http://dx.doi.org/10.1016/j.applthermaleng.2015.06.029 (cit. on pp. 41, 67, 187). 
"Get rid of all the impressions of the senses and the imagination, and do not trust yourself but of the reason"

René Descartes

\section{Chapter 3}

Methodology 



\section{Contents}

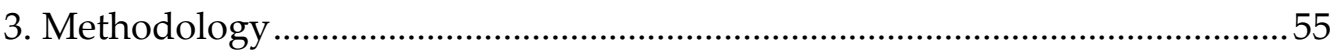

3.1. Experimental setup …................................................................................... 58

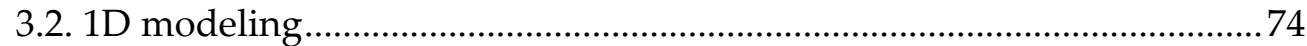

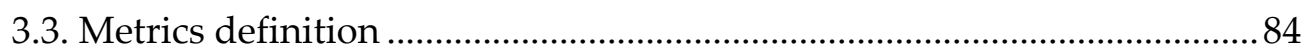

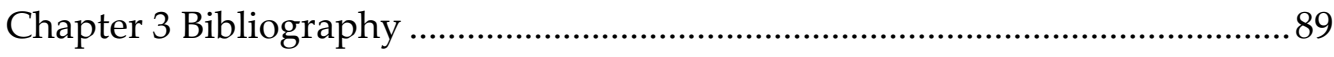




\subsection{Experimental setup}

The experiments are performed on a test bench with a turbocharged diesel engine. Table 1 shows the main features of the engine. The engine includes both LP and HP EGR systems. This study is focused only in the HP EGR loop of the engine.

\section{Table 3.1}

Engine specifications.

$\begin{array}{ll}\text { Cylinder number } & \text { In-line } 4 \\ \text { Bore } x \text { stroke }(\mathrm{mm}) & 80 \times 79.5 \\ \text { Displacement }\left(\mathrm{cm}^{3}\right) & 1600 \\ \text { Compression ratio } & 15.4: 1 \\ \text { Valve number } & 4 / \text { cylinder } \\ \text { Fuel delivery system } & \text { Common rail. Direct injection. } \\ \text { EGR system } & \text { HP EGR and LP cooled EGR } \\ \text { Intake boosting } & \text { Turbocharger with VGT } \\ \text { Intake cooling system } & \text { Air charge air cooler (ACAC) } \\ \text { Maximum power }(\mathrm{kW} / \mathrm{rpm}) & 96 / 4000 \\ \text { Maximum torque }(\mathrm{Nm} / \mathrm{rpm}) & 320 / 1750\end{array}$

The original configuration in the intake manifold was modified in order to measure the $\mathrm{CO}_{2}$ concentration pipe to pipe for all cylinders. In this way, the EGR dispersion level could be measured with precision. The installation of a specific hardware was based on eight runners where there were installed eight probes to measure the gas composition as Figure 3.1 shows. In addition, in the same probe there were two orifices, one to $\mathrm{CO}_{2}$ concentration (horizontal) and other to temperature (vertical). 


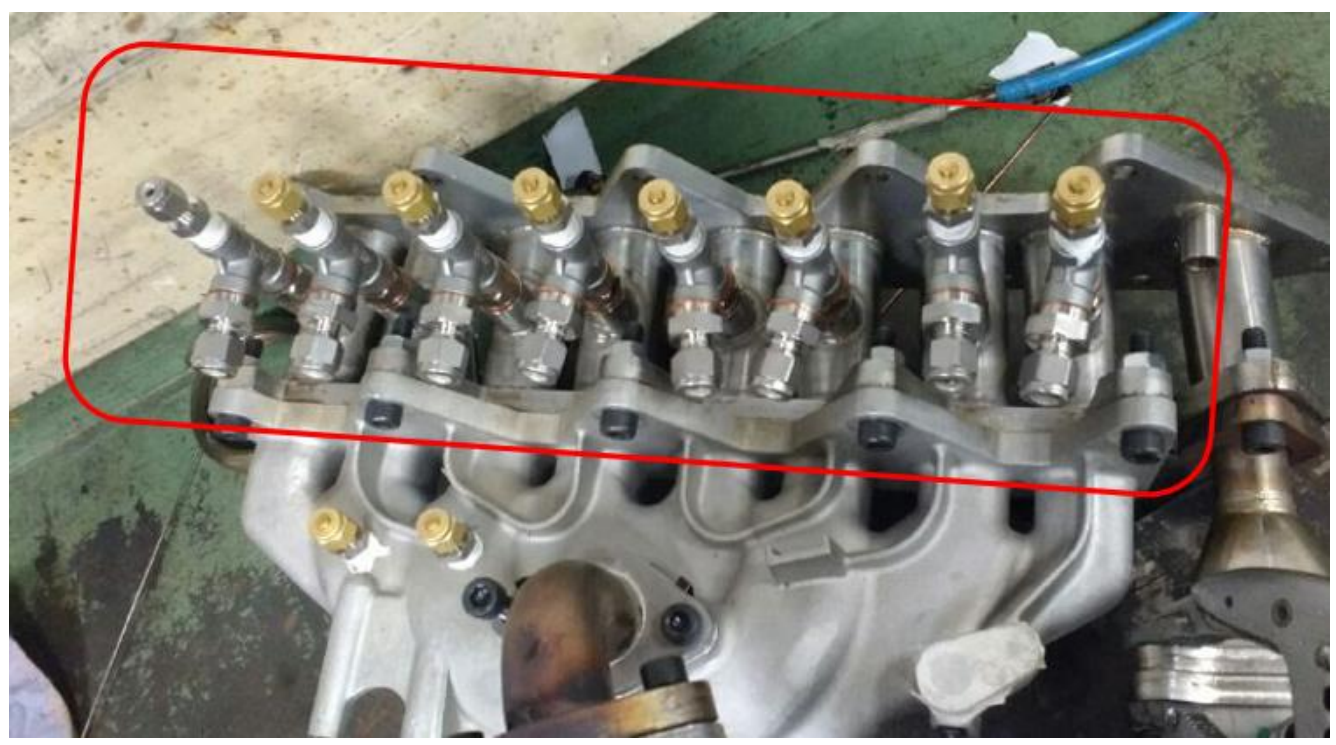

Figure 3.1. The eight probes installed in the intake to measure the gas composition in every pipe.

In fact, up to nine probes were installed, one per pipe (two per cylinder) and an additional one which measures the environment to perform the change of the acquisition between pipes. The probes were connected to a Horiba MEXA 7170DEGR, which is a conventional gas analysis system widely used in engine testing in steady conditions. The Horiba MEXA 7170DEGR specifications are detailed in Table 3.2.

Moreover, six extra probes were installed in order to evaluate the exhaust gases transport in the intake line, from the manifold to the cylinders, by a fast $\mathrm{CO}_{2}$ tracking system based on Non-Dispersive Infra-Red measuring principle. The $\mathrm{CO}_{2}$ tracking system is able to detect changes in gas concentration with a T90 of $8 \mathrm{~ms}$, which is a higher sampling frequency than other conventional gas analysis systems, like the Horiba MEXA 7170DEGR [3]. More details of the fast $\mathrm{CO}_{2}$ tracking system are detailed in Table 3.3. 
Table 3.2

Horiba MEXA 7170DEGR specifications.

\begin{tabular}{lcc} 
Horiba MEXA 7170DEGR & Variable & Range \\
\hline Linearity & $\%$ & \pm 1 FS \\
& $\% 2$ of the readings & \pm 0.5 FS for zero point \\
Repeatability & $\% / h$ & \pm 1 FS/24 for zero point \\
& & \pm 1 of the readings/24 for span point \\
Drift & $\%$ of the readings for span point \\
Ambient temperature & $\%$ & 50 \\
Relative humidity & $\%$ & 80
\end{tabular}

Table 3.3

Fast $\mathrm{CO}_{2}$ tracking system specifications.

\begin{tabular}{lcc} 
Fast $\mathrm{CO}_{2}$ tracking system & Variable & Range \\
\hline Linearity & $\%$ & $\pm 2 \mathrm{FS}$ \\
Repeatability & $\%$ & $\pm 2 \mathrm{FS}$ \\
Drift & $\% / \mathrm{h}$ & \pm 2 FS for zero drift (20\% range) \\
& & \pm 2 FS for span drift (20\% range) \\
Ambient temperature & ${ }^{\circ} \mathrm{C}$ & $0-40$ (approx. 25-40 without \\
& & changing setpoints)
\end{tabular}

Four of the six fast $\mathrm{CO}_{2}$ tracking system probes were installed in the runners of the specific hardware that lead to two cylinders (two ducts for each cylinder), 
and the other two were installed in the other end of the intake manifold, before the runners like it is possible to see in Figure 3.2. The probes located in the runners are slightly inclined due to spatial criteria but it does not affect the accuracy of the measurement system.

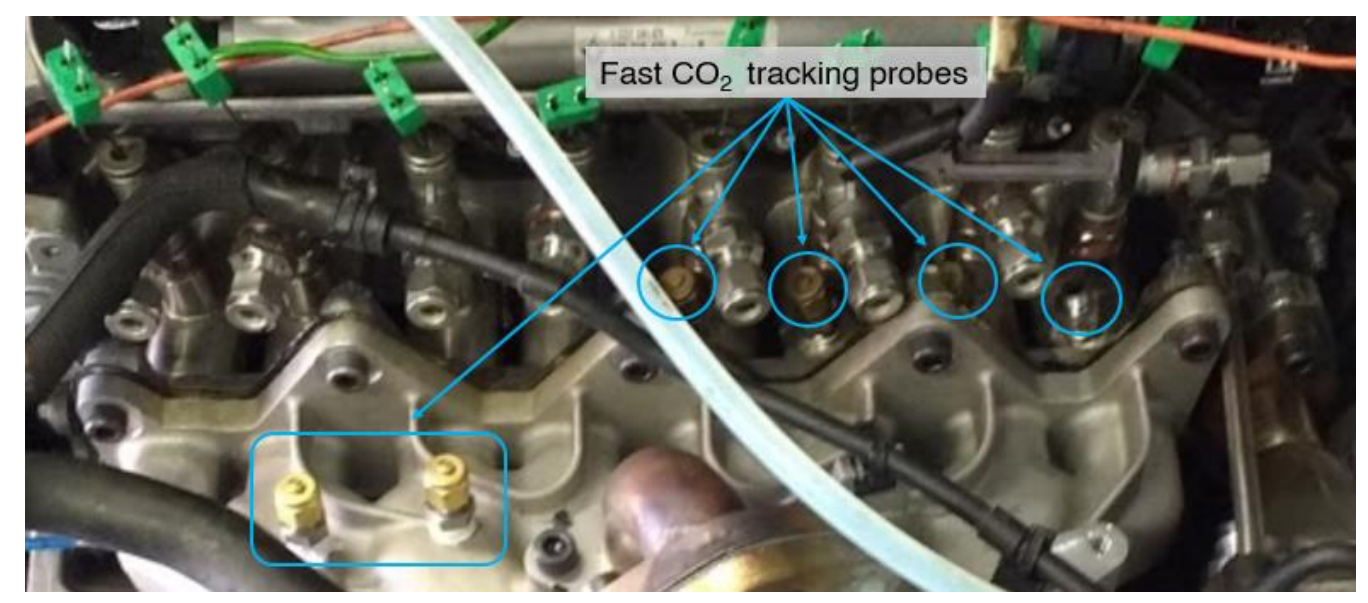

Figure 3.2. The six fast $\mathrm{CO}_{2}$ tracking probes installed in the intake.

In Figure 3.3 a detail of the final assembly is showed with the thermocouples, the probes of Horiba MEXA 7170DEGR and the inclined probe of the fast $\mathrm{CO}_{2}$ tracking system that could only sample one position per test. Therefore, the other probes must were been capped and the running conditions must were been repeated five more times to measure with the fast $\mathrm{CO}_{2}$ tracking system at each location.

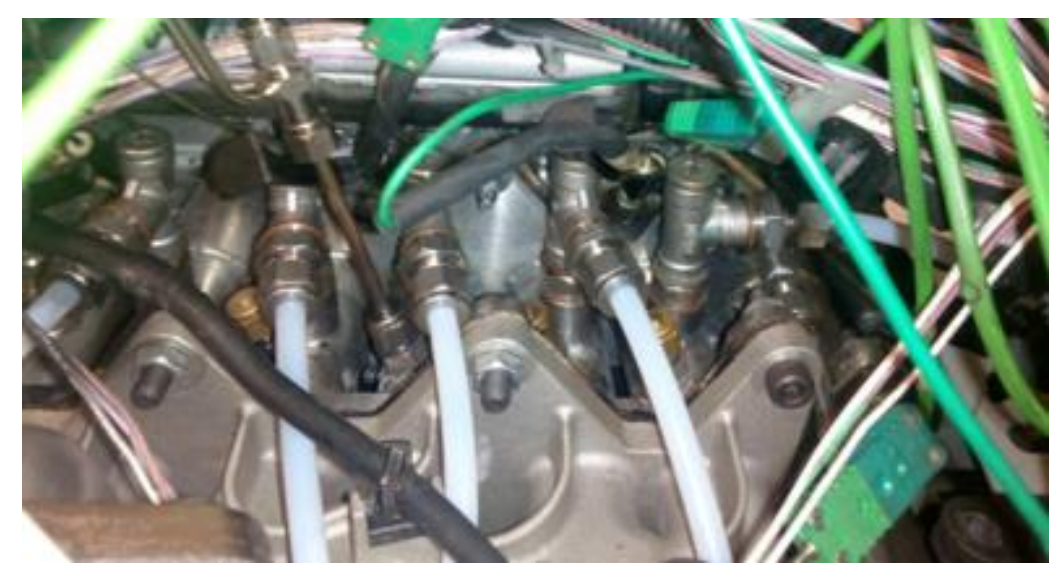

Figure 3.3. Detail of the final assembly in the intake manifold. 
The detail of the sampling pipes in the intake runners is showed in Figure 3.4. The shells were welded to the top of the runners and pierced them a third of their diameter approximately (red line) in order to the acquisition of the gases came from the center of the runners. On the other hand, the thermocouples pierced the runner, inside the shell, a few more millimeters, up to the middle approximately (green line) to sample the temperature from the center of the runner too. Finally, the shells of the fast $\mathrm{CO}_{2}$ tracking system were placed without entering into the runner, they were located in the rim due to the probe could pierced through the runner up to the middle too.

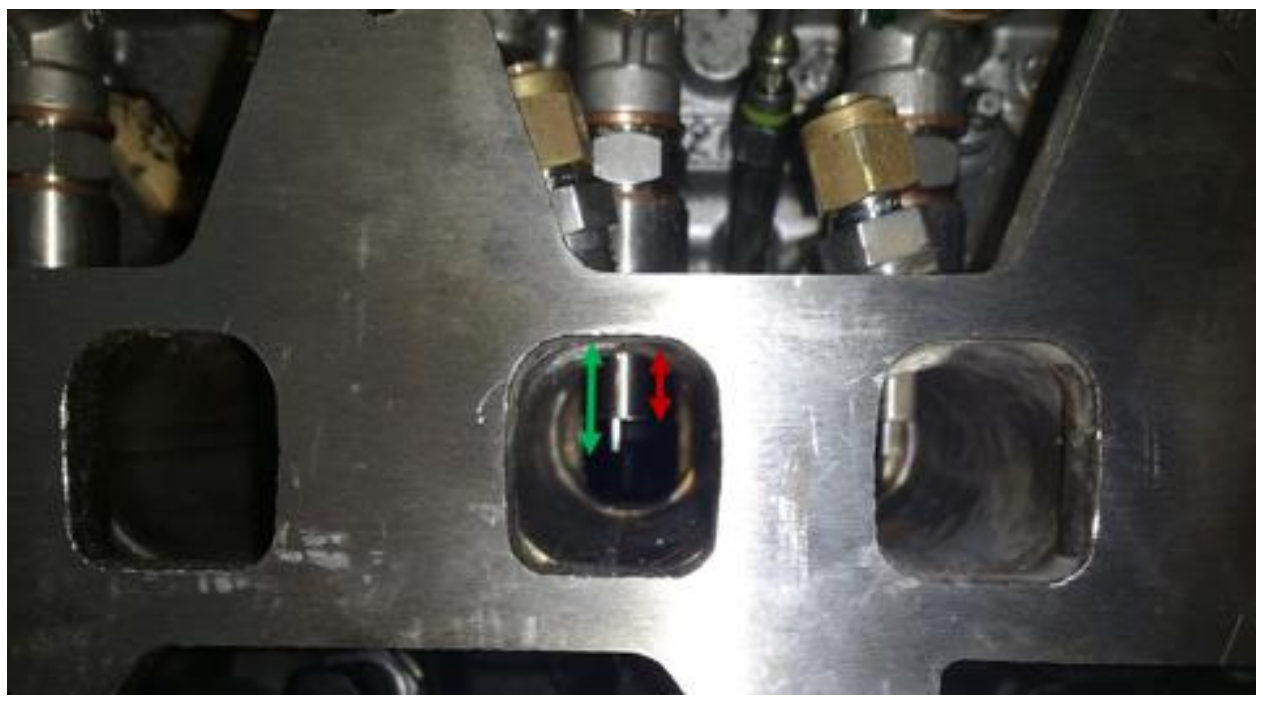

Figure 3.4. Detail of the sampling pipes in the intake runners.

Figure 3.5 shows two pictures. The left one presents the length of the fast $\mathrm{CO}_{2}$ tracking probe into the runner before the assembly, and the right one exhibits the fast $\mathrm{CO}_{2}$ tracking probe in the manifold after the assembly. The length of the probe was measured before the assembly (left picture) in the six different locations in order to know the precise position where the end of the probe were in the middle of the runner to acquire the gas sample from the center of the flow. After the assembly (right picture), the length of the probe over the location was measured each time to know the correct position before the test. 


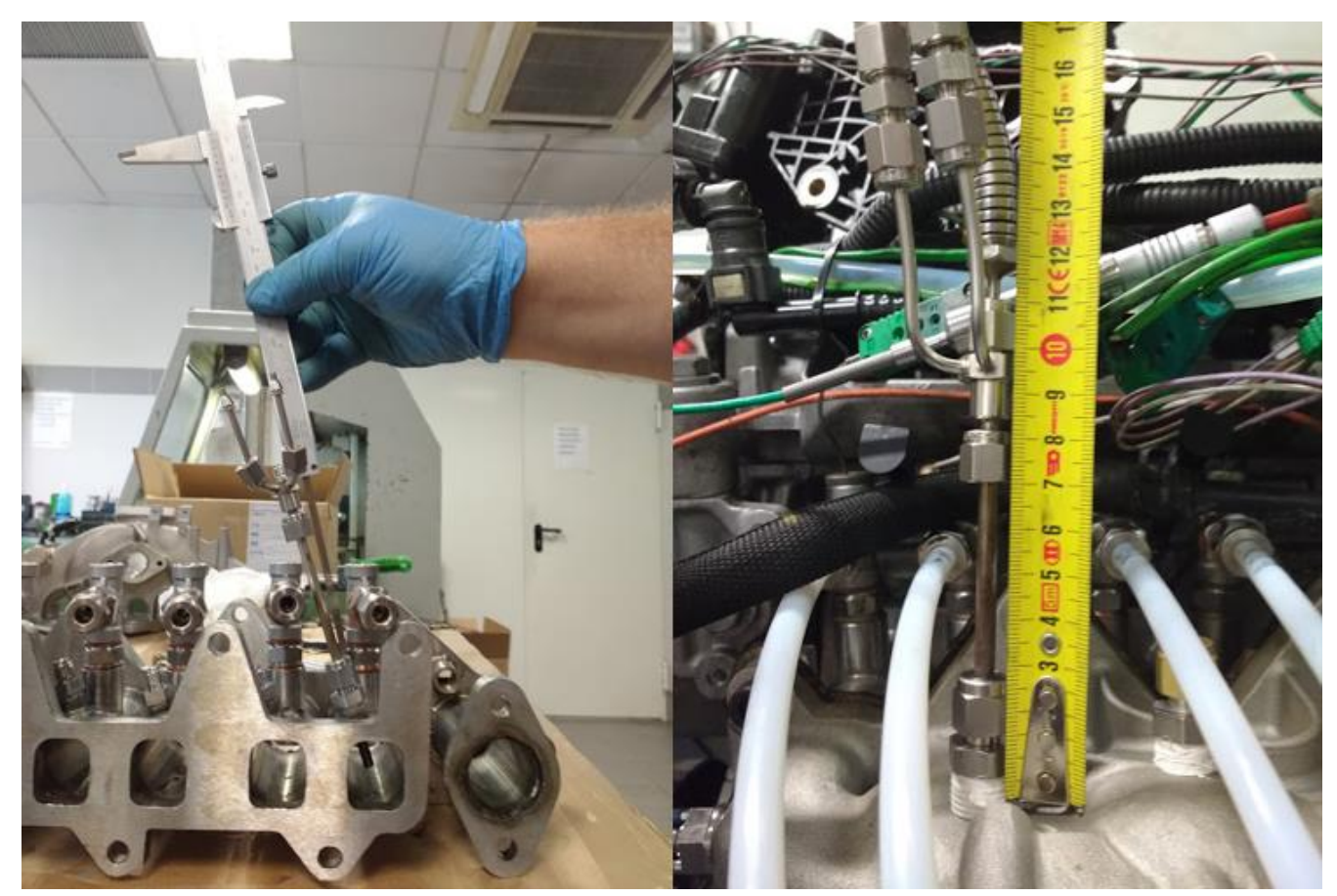

Figure 3.5. Detail of the fast tracking $\mathrm{CO}_{2}$ probes location.

Nine different valves joined in a rail, shown in Figure 3.6, control the mass flow to the gas analyzer Horiba MEXA 7170DEGR, one for each probe and the ninth to change the probe acquisition. Usually, one of the valves was opened while the others were closed, to measure only the gas composition from one pipe. It is not possible to close one valve and open another after that, because the acquisition system is breathing continuously and it would generates vacuum and it could damage the measuring device. For this reason, it was necessary to open first another valve and then close the previous one. Due to the ninth probe measured the ambient gas composition, so it measured a very low $\mathrm{CO}_{2}$ level, it was easier to detect the probes acquisition changes in the post-processing phase. 


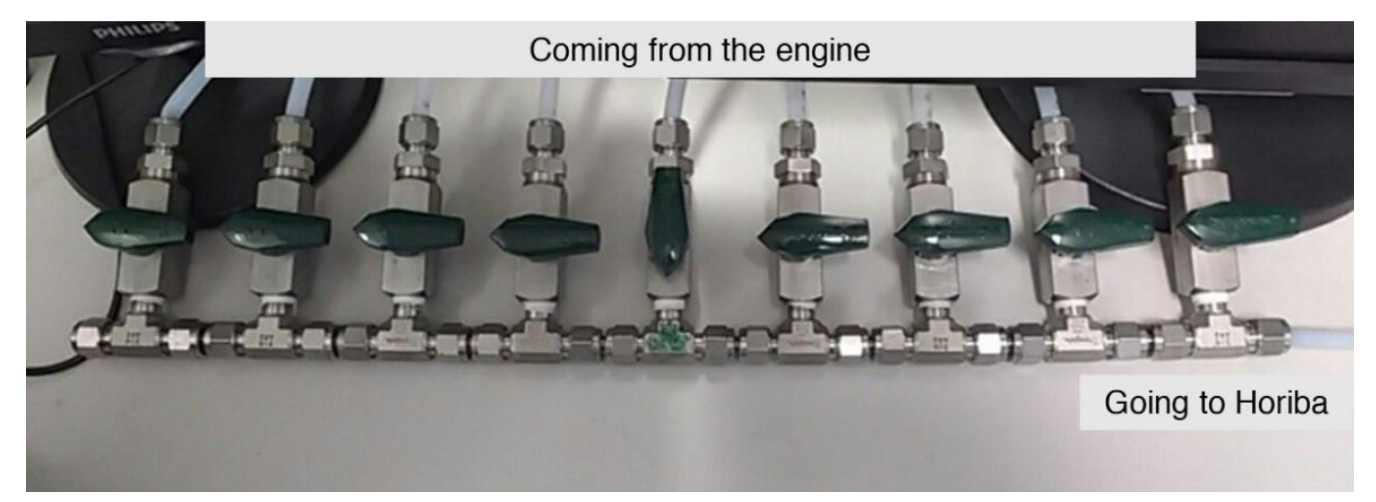

Figure 3.6. Rail and valves for intake gas measurement selection.

Similar configuration was applied in the exhaust line, where it was performed cylinder to cylinder (four probes) and not pipe to pipe. In this case the installation of a specific hardware, like in the intake, was not necessary because there was enough space to install the probes of the Horiba MEXA 7170DEGR and there was no other pipe to pipe measurement devices. Therefore, the probes were installed directly in the manifold, close to the cylinders, as it is possible to observe in Figure 3.7, to minimize the cylinder to cylinder contamination. As opposite to the intake, probes were threaded and they were placed without entering into the runner more than the necessary to fix themselves, they were located close to the rim due to the exhaust gases are well mixed and it is not necessary to measure from the center of the flow. The installation of a similar acquisition system in the exhaust allowed to measure the NOx emissions cylinder to cylinder and to determine the influence of the EGR dispersion on them.

The four probes and an additional one, placed downstream of the turbine, to account for overall raw engine emissions. All of them were connected to the same gas analyzer system than the intake probes, the Horiba MEXA 7170DEGR. As in the intake system, the five probes included a valve to control the location of the gas flow that the gas analyzer Horiba MEXA 7170DEGR was analyzing, as it is possible to observe in next Figure 3.8. 


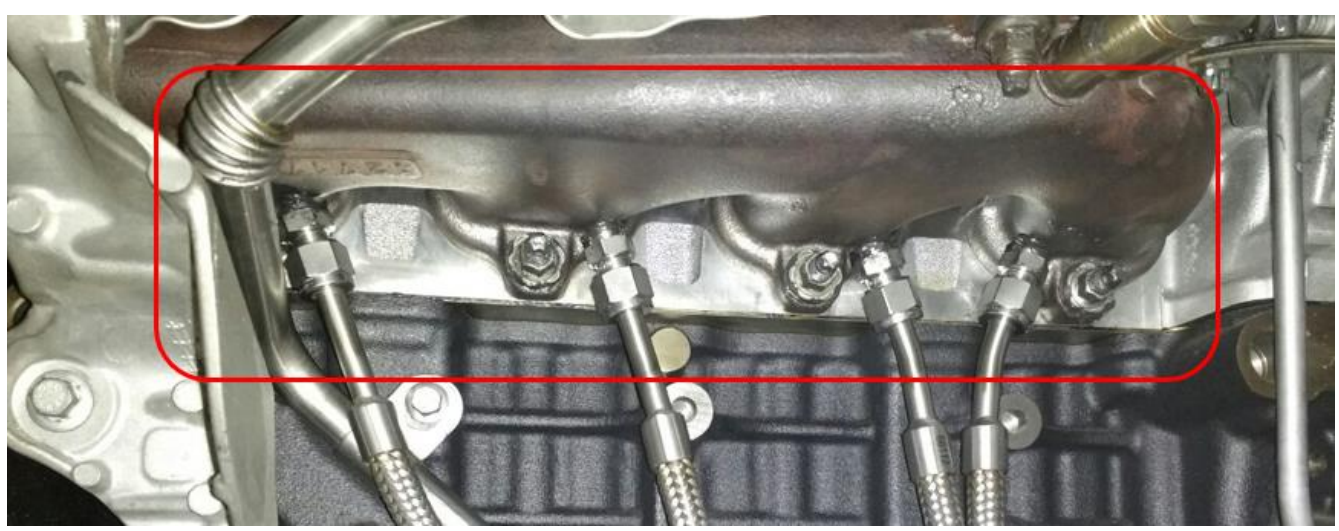

Figure 3.7. Four probes installed in the exhaust to measure the gas composition in every exhaust pipe.

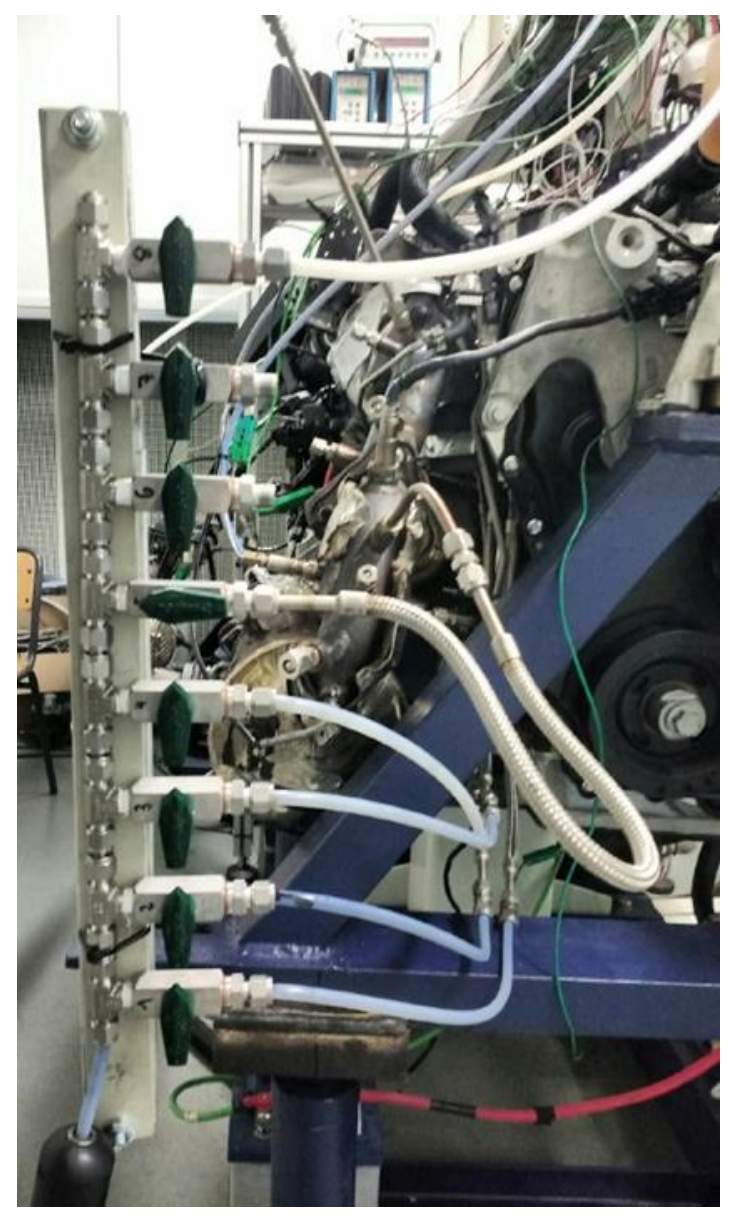

Figure 3.8. Rail and valves for exhaust gas measurement selection. 
Firstly, three different devices to mix the EGR with the air in the manifold were tested. These devices were named "mixers" because it achieves the function of mixing the EGR with the intake air in the manifold. Figure 3.9 shows the devices. Mixer 1 is a conventional design that introduces the EGR vertically on the manifold from the top and has some windows to allow the entrance of the EGR. Mixers 2 and 3 are modifications of the mixer 1. Mixer 2 was modified to orientate the EGR flow to the entrance of the air in the manifold to improve the mix between the EGR and the air. Finally, mixer 3 is deliberately altered to deflect the EGR to one side of the manifold and generate a high asymmetry and, therefore, a high HP EGR dispersion. The mixers were tested at the same engine running conditions to evaluate the influence of the geometry in the mix between air and EGR and, therefore, in the HP EGR dispersion as a preliminary study. Before every round of tests, when every measurement devices were turned on, their filters were checked and changed in the necessary cases (i. e. if the filters were dirty) and the measurement devices where purged and calibrated to ensure the correct measurements. The purged process was recurrent after each measurement.

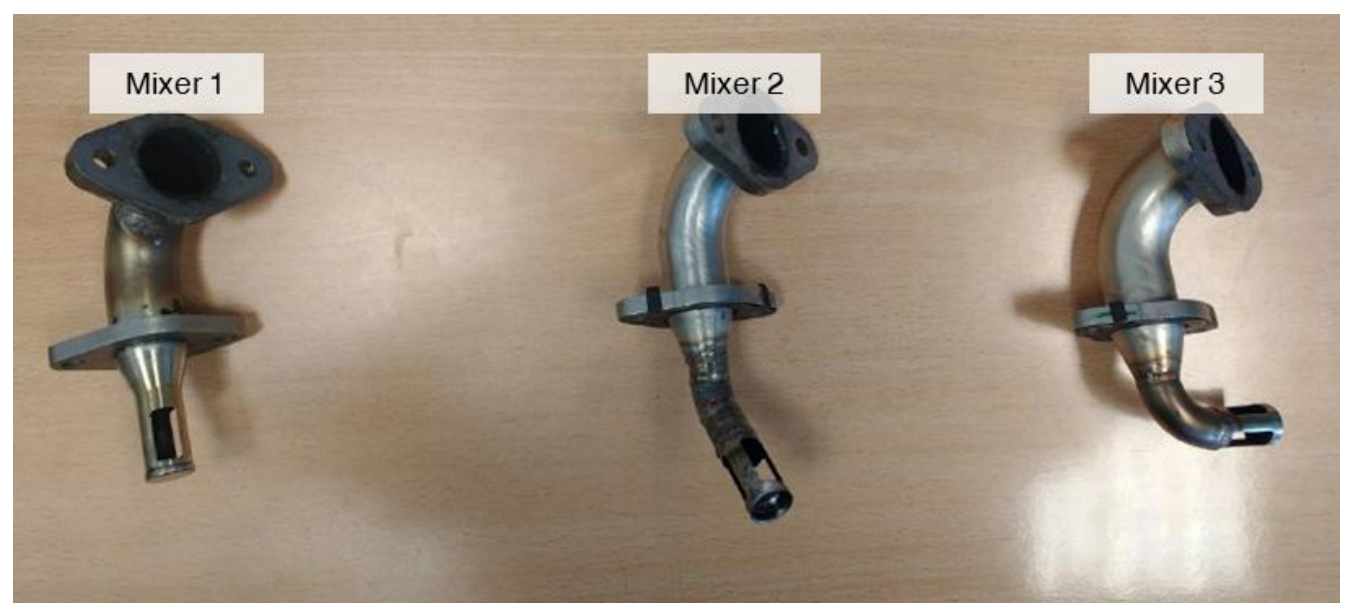

Figure 3.9. Devices that introduce and mix the EGR with the intake air in the manifold.

In a second and more elaborated approach, a specific manufactured device was installed between the HP EGR line and the intake manifold with three pipes and three regulation valves (one per pipe) to control the HP EGR dispersion for the second experimental phase, after the mixers tests. The pipes were 
distributed in the intake manifold to encompass it. One pipe was located on the left, other was located on the right and the third was located on the center, on the top of the manifold, as in the original configuration when mixers were used. Each pipe contained a regulation valve to control the HP EGR dispersion with high accuracy as it is observed in Figure 3.10. This study provides higher precision and combinatorial that promotes more variety of dispersion levels than previous studies that employed some different manifolds [14] or mixers $[15,106,109]$.

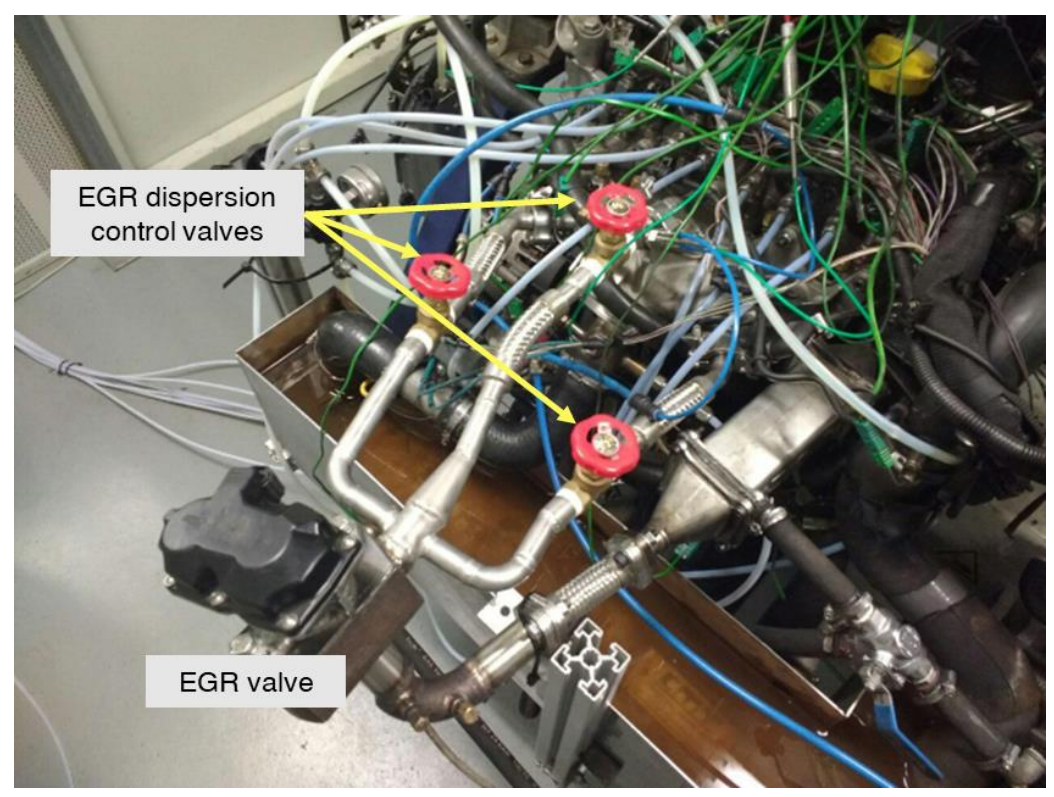

Figure 3.10. Manufacturing device with three regulation valves to control de HP EGR dispersion.

Different sensors were installed additionally to measure different engine parameters, which help to set the steady engine conditions to perform the tests. They also offer a lot of information to process properly the results. The variables together with the sensors features are presented in Table 3.4. 
Table 3.4

Instrumentation accuracy.

\begin{tabular}{|c|c|c|c|}
\hline Sensor & Variable & Accuracy [\%] & Range \\
\hline Thermocouples type K & Temperature & 1 & $0^{\circ} \mathrm{C}-1260^{\circ} \mathrm{C}$ \\
\hline Pressure sensor & Pressure & 0.3 & 0 - 6 bar \\
\hline Pressure sensor & Pressure & 0.05 & $0-150$ bar \\
\hline $\begin{array}{l}\text { Gravimetric fuel } \\
\text { balance }\end{array}$ & Fuel mass flow & 0.2 & $0-150 \mathrm{~kg} / \mathrm{h}$ \\
\hline Hot wire meter & Air mass flow & 1 & $0-720 \mathrm{~kg} / \mathrm{h}$ \\
\hline Dynamometer brake & Torque & 0.1 & $0-480 \mathrm{Nm}$ \\
\hline Smoke Meter & Soot & 0.5 & $0-32000 \mathrm{mg} / \mathrm{m}^{3}$ \\
\hline
\end{tabular}

In the preliminary study, with the mixers, the $\mathrm{CO}_{2}$ fast tracking system was used to evaluate the transport of exhaust gases in the intake line. Since up to six locations in the intake manifold are used for the 1D model assessment, engine tests have to be repeated six times in a row to provide the needed data. Special care was paid to ensure the repeatability of the engine running point stabilization so, to avoid the continuous loading of the diesel particulate filter, this unit was removed in these tests and replaced by a device that provided a similar pressure drop in a specific particulate matter load conditions. In addition the main parameters monitored to ensure the repeatability were engine speed and torque, fuel consumption, air mass flow, intake temperature (controlled by cooler), EGR rate, intake pressure, exhaust pressure and NOx emissions.

The six locations for the instantaneous measurement of the $\mathrm{CO}_{2}$ concentration are depicted in Figure 3.11. Location $\# 1$ and $\# 2$ are placed in the intake manifold; $\# 1$ is in front of cylinder $1, i$. e. facing a cylinder in one of the extremes of the engine block, while \#2 is in a location between location \#1 and the EGR 
discharging central branch. Locations $\# 3, \# 4, \# 5$ and $\# 6$ are placed directly in the intake pipes of cylinders 3 and 4 .

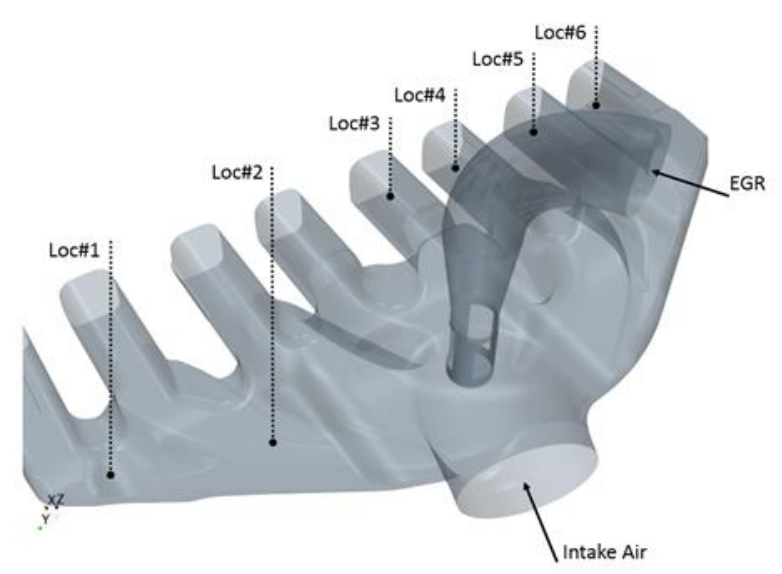

Figure 3.11. Intake manifold representation with the six locations for the fast $\mathrm{CO}_{2}$ tracking system.

Figure 3.12 shows an engine schematic layout where it is possible to observe the locations of the different measurement devices. The probes connected to the Horiba MEXA 7170 DEGR are marked in red, they are eight probes in the intake, one per pipe, and five in the exhaust, one per cylinder and other in the exhaust line downstream the turbine.

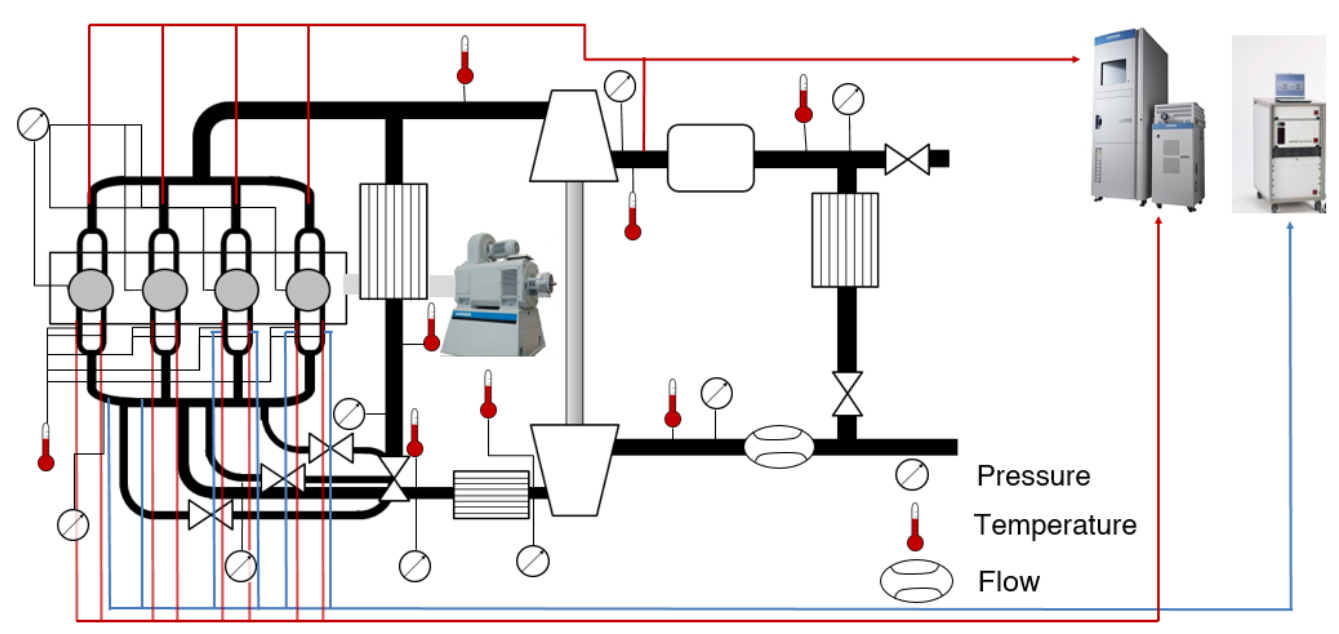

Figure 3.12. Engine schematic layout. 
In addition, in Figure 3.12 the $\mathrm{CO}_{2}$ fast tracking probes are marked in blue, six in total, two in the left side of the manifold, and four in the pipes of cylinders $\# 3$ and \#4. Figure 3.13 shows a detail of cylinder 3 with four probes, two to Horiba (red) and two to $\mathrm{CO}_{2}$ fast tracking (blue).

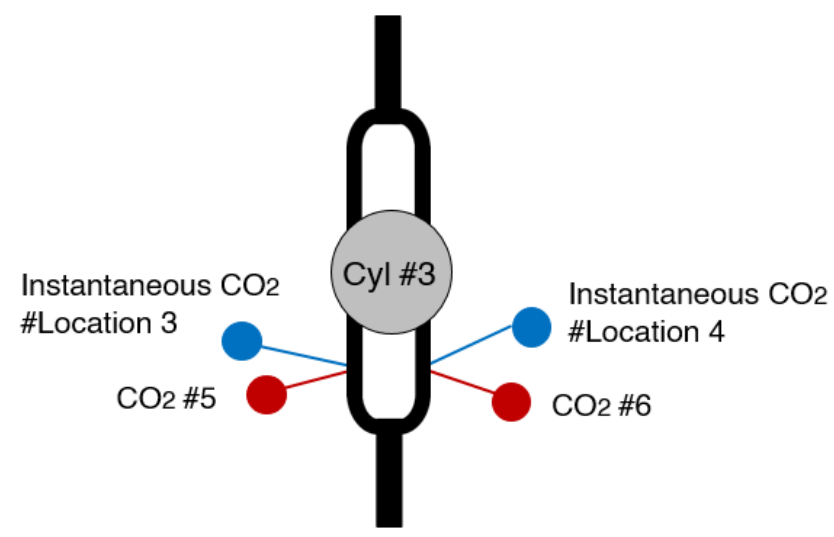

Figure $3.13 \mathrm{CO}_{2}$ measurement detail in cylinder 3.

Engine tests in steady conditions were performed to analyze the dispersion of the HP EGR and its effect on the NOx and smoke emissions as well as to evaluate the $1 \mathrm{D}$ model. The determination of the engine operation points was performed in two steps: First step, the preliminary study and second step, the detailed study.

It was necessary to determine the operating points taking care to study a large range in the engine map. Initially, two engine speeds were defined with four different Brake Mean Effective Pressure (BMEP) and three different EGR rates. The working operation points defined encompass a big range of the engine map including high loads and high EGR rate what is a novelty in the literature. Moreover, before the selection in the second step of the working operation points to perform the detailed study, other EGR rates were tested (shown in brackets) to collect more information and asses the influence of the EGR rate variations in HP EGR dispersion. The working operation points to perform the preliminary study are shown in Table 3.5. 
Table 3.5

Working operation points to perform the preliminary study.

\begin{tabular}{ccccc}
$\begin{array}{c}\mathrm{N} \\
{[\mathrm{rpm}]}\end{array}$ & $\begin{array}{c}\text { BMEP } \\
{[\mathrm{bar}]}\end{array}$ & $\begin{array}{c}\text { Intake } \mathrm{P} \\
{[\mathrm{mbar}]}\end{array}$ & $\begin{array}{c}\text { EGR rate } \\
{[\%]}\end{array}$ & $\begin{array}{c}\text { Engine Torque } \\
{[\mathrm{Nm}]}\end{array}$ \\
\hline 1500 & 1 & 1000 & $42(7,22,29)$ & 13 \\
1500 & 3 & 1040 & $5(3,10,20)$ & 38 \\
2500 & 10 & 2100 & $20(3,7,17)$ & 129 \\
2500 & 19 & 2660 & 5 & 231 \\
\hline
\end{tabular}

After the preliminary study, three more engine speeds were added with five different BMEP. After that, the EGR rate was determined under two restrictions: the first one was to study a large range between low and medium EGR rate, and the second one was to keep margin to be able to modify the HP EGR dispersion taking into account the effect on the engine stability, highly affected when the air to fuel ratio approaches to stoichiometric conditions. Finally, the EGR rate to perform the study was determined as a function of the emissions and the stability. As before, some additional EGR rates were tested to study the influence of the EGR rate variations in HP EGR dispersion, they are shown in brackets. The final engine running conditions are presented in Table 3.6. 
Table 3.6.

Engine running conditions to perform the detailed study.

\begin{tabular}{ccccc}
$\begin{array}{c}\mathrm{N} \\
{[\mathrm{rpm}]}\end{array}$ & $\begin{array}{c}\text { BMEP } \\
{[\mathrm{bar}]}\end{array}$ & $\begin{array}{c}\text { Intake P } \\
{[\mathrm{mbar}]}\end{array}$ & $\begin{array}{c}\text { EGR rate } \\
{[\%]}\end{array}$ & $\begin{array}{c}\text { Engine Torque } \\
{[\mathrm{Nm}]}\end{array}$ \\
\hline 1250 & 11 & 1500 & 6 & 141 \\
1500 & 15 & 1900 & 5 & 192 \\
2000 & 6 & 1250 & $23(1.5,5$, & 76.5 \\
2500 & 11.7 & 2300 & $15,26,30)$ & \\
3000 & 20 & 2750 & 11 & 251.5 \\
\hline
\end{tabular}

In each operating point the values shown in Table 3.5 and 3.6 had to be kept constant so the control strategy during the tests was based on two different engine controls at steady conditions. The first one was the engine torque, which was controlled by the injected fuel. The second one was the intake manifold pressure, which was controlled by the Variable Geometry Turbine (VGT) position. Additionally, the working operation points in the detailed study were performed with lot of different EGR dispersion levels, which was controlled with the regulation valves device. Therefore, for these operation points, there is a third variable, the NOx emissions, which were controlled with the EGR rate, hence the HP EGR valve position. Because of that, the EGR rate variates slightly in some cases. Furthermore, in the case with some different EGR rates in brackets, the NOx levels changed, so that points are not used in the detailed study, but in the EGR rate variations effect and 1D model part of the study.

The process to perform the tests was always the same for every operation point. In the detailed study, firstly the configuration of the three valves to control the HP EGR dispersion was set before starting the engine, in the case if the preliminary tests, with the mixers, this step was not necessary, it was only mandatory to install the desired mixer previously. After that, the engine was 
started and the operation point was set (speed, torque, intake manifold pressure, EGR rate and, in the case of detailed study, NOx emissions level). It was necessary to wait to stabilize the temperature of the engine to take real steady conditions. The testing procedure started with the acquisition of $\mathrm{CO}_{2}$ concentration in the intake pipes and intake air sequentially. It required a few seconds to stabilize the measurement and obtain an accurate result, between ten and twenty seconds per pipe, depending on the working operation point.

After the registration in the intake line, the measurement of the NOx emissions in the exhaust manifold takes place. The procedure is similar to the previous one. Only one valve was open simultaneously except when the measurement probe was changed to avoid the vacuum effect. As in the intake, it is essential to wait a few seconds to stabilize the measurement. In this case the duration is longer than before, between one or two minutes for each cylinder depending on the working operation point. Moreover, the emissions are measured too downstream the turbine at the same time of the intake $\mathrm{CO}_{2}$ acquisition.

The opacity could be measured anytime, independently of the registration of other variables. It was measured with a traditional measuring device such as the AVL Smoke Meter 415S located downstream the turbine. It only needed a few seconds to take a precise measure each time. Horiba MEXA 7170DEGR is the equipment that measures the pollutant emissions, except opacity. It acquires the $\mathrm{CO}, \mathrm{CO}_{2}, \mathrm{THC}, \mathrm{O}_{2}$ and NOx concentrations [1]. It is not possible measure the EGR rate directly, so it is necessary a conversion from exhaust and intake $\mathrm{CO}_{2}$ concentration measurements [110] following the next expression:

$$
\text { EGRrate }=\frac{\left[\mathrm{CO}_{2}\right]_{\text {Intake }}-\left[\mathrm{CO}_{2}\right]_{\text {Ambient }}}{\left[\mathrm{CO}_{2}\right]_{\text {Exhaust }}-\left[\mathrm{CO}_{2}\right]_{\text {Ambient }}}
$$




\subsection{D modeling}

It is possible to simulate the flow behavior on internal combustion engines. Moreover, computational codes, computer simulations and modeling tools are widely used in engines research.

Claude-Louis Navier and George Gabriel Stokes developed the Navier-Stokes equations to describe the flow of fluids. They are a set of non-linear differential equations. At unsteady flow conditions, the Navier-Stokes equations have not a general or analytical solution, so numerical methods are necessary to solve the equation system.

The equation that must be solved are the state equations and the mass, energy and momentum conservation equations. Most of times, engines are composed of long pipes in which the flow can be considered one-dimensional, given that the length of the ducts is large enough compared to the diameter. Therefore, the most important axis is in the direction of the movement of the flow, the $\mathrm{X}$-axis. Essentially, Z-axis and Y-axis are not relevant. This is important because it allows to introduce some simplifications that significantly reduce the computation time. It is possible to propose a hyperbolic system of partial differential equations thanks to the simplification of one-dimensional Euler equations for unsteady compressible non-homentropic flow [111]. The symbolic vector form is represented in Eq. (3.2):

$$
\frac{\partial \mathrm{W}}{\partial \mathrm{t}}+\frac{\partial \mathrm{F}}{\partial \mathrm{x}}+C 1+C 2=0
$$

$\mathrm{W}$ corresponds to the mass, momentum and energy aggrupation terms, $\mathrm{F}$ is the flux of these terms and $C$ represents the source terms. In Eq. (3.2), the more basics source terms are included, which take into account the friction, the area changes and the heat transfer effects. Nevertheless, it would have additional source terms, which are not defined in Eq (3.2), but that take into account other less influential effects like viscosity. The strong conservative form of Eq. (3.2) is represented in Eq. (3.3) [76]: 


$$
\begin{aligned}
& W(x, t)=\left[\begin{array}{c}
\rho \mathrm{F} \\
\rho \mathrm{uF} \\
F\left(\rho \frac{u^{2}}{2}+\frac{p}{\gamma-1}\right)
\end{array}\right] \\
& F(W)=\left[\begin{array}{c}
\rho \mathrm{uF} \\
\left(\rho u^{2}+\mathrm{p}\right) \mathrm{F} \\
u F\left(\rho \frac{u^{2}}{2}+\frac{\gamma p}{\gamma-1}\right)
\end{array}\right] \\
& C 1(x, W)=\left[\begin{array}{c}
0 \\
-p \frac{d F}{d x} \\
0
\end{array}\right] \\
& C 2(W)=\left[\begin{array}{c}
0 \\
g \rho F \\
-q \rho F
\end{array}\right]
\end{aligned}
$$

Furthermore, the chemical species could be taken into account and included in the equation system. The solution procedure and the accuracy of the numerical methods do not change with the addition of the chemical species to the governing equations. Nevertheless, it is required the addition of $n-1$ equations, where $\mathrm{n}$ is the number of the chemical species. The vector form of the chemical species conservation equation is represented in Eq. (3.4):

$$
\frac{\partial(\rho Y F)}{\partial t}+\frac{\partial(\rho u Y F)}{\partial x}=\rho F \dot{Y},
$$

$\mathrm{Y}$ expressed in Eq. (3.4) is a vector that includes the mass fraction of $\mathrm{n}-1$ different chemical species. The Eq. (3.5) is a compatibility equation that gives the mass fraction of the chemical species $\mathrm{n}$ :

$$
Y_{n}=1-\sum_{j=1}^{n-1} Y_{j}
$$

The inclusion of the chemical species in the governing equations is represented in Eq. (3.6): 


$$
\begin{aligned}
& W(x, t)=\left[\begin{array}{c}
\rho \mathrm{F} \\
\rho \mathrm{F} \\
F\left(\rho \frac{u^{2}}{2}+\frac{p}{\gamma-1}\right) \\
\rho F Y
\end{array}\right] \\
& F(W)=\left[\begin{array}{c}
\rho \mathrm{uF} \\
\left(\rho u^{2}+\mathrm{p}\right) \mathrm{F} \\
u F\left(\rho \frac{u^{2}}{2}+\frac{\gamma p}{\gamma-1}\right) \\
\rho u F Y
\end{array}\right] \\
& C 1(x, W)=\left[\begin{array}{c}
0 \\
-p \frac{d F}{d x} \\
0 \\
0
\end{array}\right] \\
& C 2(W)=\left[\begin{array}{c}
0 \\
g \rho F \\
-q \rho F \\
\rho F \dot{Y}
\end{array}\right]
\end{aligned}
$$

As it was commented before, the resolution of these equations requires the use of numerical methods. Depending on the problem to solve, the numerical method employed by the software could vary according to the adaptation of the different methods to the needed of resolution.

OD elements are often used in engine locations where the flow has not a clearly dominant characteristic length. These elements are widely employed because they use faster solving equations and, therefore, consume less computational. Moreover, a very relevant characteristic of OD elements is that only the mass and energy conservation equation for open systems are applied, alongside the ideal gas state equation. It is obvious that the momentum conservation equations do not need to be solved in 0D elements.

The inclusion of the chemical species in the equation system requires the addition of $n-1$ equations, just like before.

$$
\Delta m_{i n_{Y_{j}}}=\sum_{i} \dot{\mathrm{m}}_{i} Y_{j c C_{i}} \Delta t
$$

$m_{i n_{Y_{j}}}$ expressed in Eq. (3.7) represents the mass of the chemical species $j$ inside the $0 \mathrm{D}$ element and $Y_{j c c_{i}}$ represents the mass fraction of the chemical species $\mathrm{j}$ 
entering to or exiting from the 0D element through the boundary condition $i$. Finally, the mass fraction of the chemical species $j$ at time instant is expressed in Eq. (3.8):

$$
Y_{j}=\frac{m_{i n_{Y_{j}}}+\Delta m_{i n_{Y_{j}}}}{m_{i n}+\Delta m_{i n}}
$$

Like before, the Eq. (3.5) is a compatibility equation that gives the mass fraction of the chemical species $n$ [112]. The species considered in the model of the present study are air, burned gas and fuel.

The air is composed by unburned nitrogen and oxygen and the fuel is divided between vapor and liquid fuel. Burned gases take into account 11 standard chemical species $\left(\mathrm{CO}_{2}, \mathrm{H}_{2} \mathrm{O}, \mathrm{N}_{2}, \mathrm{O}_{2}, \mathrm{CO}, \mathrm{H}_{2}, \mathrm{H}, \mathrm{O}, \mathrm{OH}, \mathrm{NO}\right.$ and $\left.\mathrm{N}\right)$. If argon and sulfur are found, they are added to the list too $\left(\mathrm{Ar}\right.$ and $\left.\mathrm{SO}_{2}\right)$, and the chemical species considered are 13.

In order to solve the Navier-Stokes equations there are two different integration methods: the explicit and the implicit. For the explicit method, the main solution variables are mass flow, density and internal energy. Meanwhile, for the implicit method, the main solution variables are mass flow, pressure and total enthalpy

The intake manifold is composed by a combination of volumes and pipes which are connected by junctions in a convenient manner. In the volumes, the scalar variables (temperature, pressure, density, species concentration, etc.) are calculated, whereas vector variables (velocity, momentum, mass fraction, etc.) are calculated in the junctions connecting two volumes or a volume and a duct.

For the volumes, the following characteristics are defined: volume of the geometry, surface area, wall heat transfer multiplier, friction multiplier, expansion diameters, characteristic length and boundary angles. The heat transfer multiplier and friction multiplier are usually used to adjust the model. The value of these multipliers is one by default, and they multiply the source terms (C), so the multipliers do not change the value of the source terms excepting when these multipliers are modified. The maximum diameter that the flow may expand to after entering a boundary is named the expansion diameter. It is used in order to model the contraction and expansion losses. 
Besides those parameters, the relative orientation in which the junctions are connected to the volumes has to be set, so the 3D effects can be taken into account. In the pipes: diameter, length, discretization length, radius and angle of bend, wall heat transfer multiplier and friction multiplier are defined. Like in the volumes, the heat transfer multiplier and friction multiplier are usually used to adjust the model. For the junctions, only the information of what two volumes they connect is needed, as well as a discharge coefficient to adjust the model.

An important aspect to highlight is that in volumes several boundaries can be attached, unlike in ducts, where there can only be one junction in each end, one for as the intake and another one as the exhaust. The orientation and the direction of the flow is taken into account in the junctions, although the vector equations are solved in its one-dimensional simplified form. This implies that the manifold is a combination of different elements and it works like a quasi3D model approximation that presents a lower computational cost than a conventional 3D model, since the equations are solved in their 0D or 1D form. However, it offers a better accuracy than $0 \mathrm{D}$ or $1 \mathrm{D}$ modeling because it is able to take into account the three dimensional orientation in the junctions of the volumes and, with that, some of the main three dimensional effects of the flow $[102,73]$.

The quasi-3D modeling approximation for this study is possible due to a specific software that import the mesh of the geometry of the intake manifold from a computer-aided design (CAD) file to the 1D modeling tool used. Therefore, in this case, the software, thanks to the CAD file, calculates the volumes, surface area, expansion diameters, characteristic lengths and boundary angles of the volumes and diameters, lengths, discretization lengths, radius and angle of bend of the pipes.

The CAD file of the manifold was manually transformed to a combination of volumes and pipes in the model. When the specific software opens the CAD file, it allows to do a partially selections of the whole manifold, dividing it and indicating what kind of pieces they should be in the model, for instance volumes or pipes, like it is possible to see in Figure 3.14. The main advantage of using the CAD file information is that the geometry in the model is quite 
realistic. In addition, the junctions among the different pieces keep their orientation and surface area due to they are taken by the software and imported to the model, achieving the quasi-3D effect in the simulation.

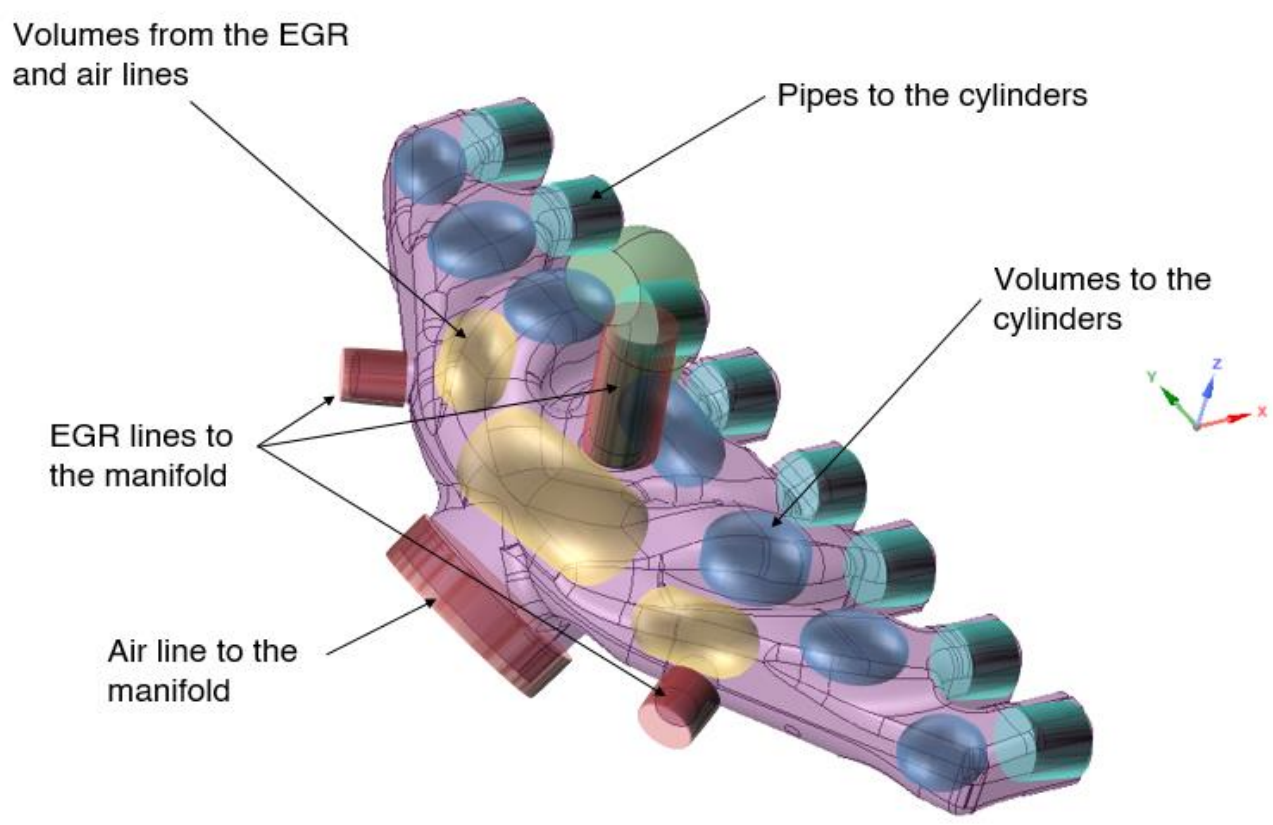

Figure 3.14 Division of the intake manifold CAD file in volumes and pipes to the model.

Figure 3.15 shows the schematic representation of the intake manifold by the model. The junctions of the volumes, where discharge the EGR and the inlet air, among them, in addition with the EGR and air lines, and the volumes after them, in the flow's sense, is observed in first place. Similar situation is presented in the next volumes which join with the pipes that go on to the cylinders but they join among them too. The junction among the volumes allows a free movement to the flow not only in the direct sense of the flow to the cylinders, so to the sides too. The simulation is more complex in this way, closer to real movement inside the manifold. This fact, besides the boundary angles, the surface areas and the volume sizes are taken into account thanks to importation of the CAD's file, offer a very realistic simulation. The number of volumes and pipes is important to try to solve the intake manifold flow with accuracy. The orientation of the angles of the pipes is crucial to obtain faithful results 
according to EGR dispersion, and the physical limitation of volumes and pipes take direct consequences in the quality of the results.

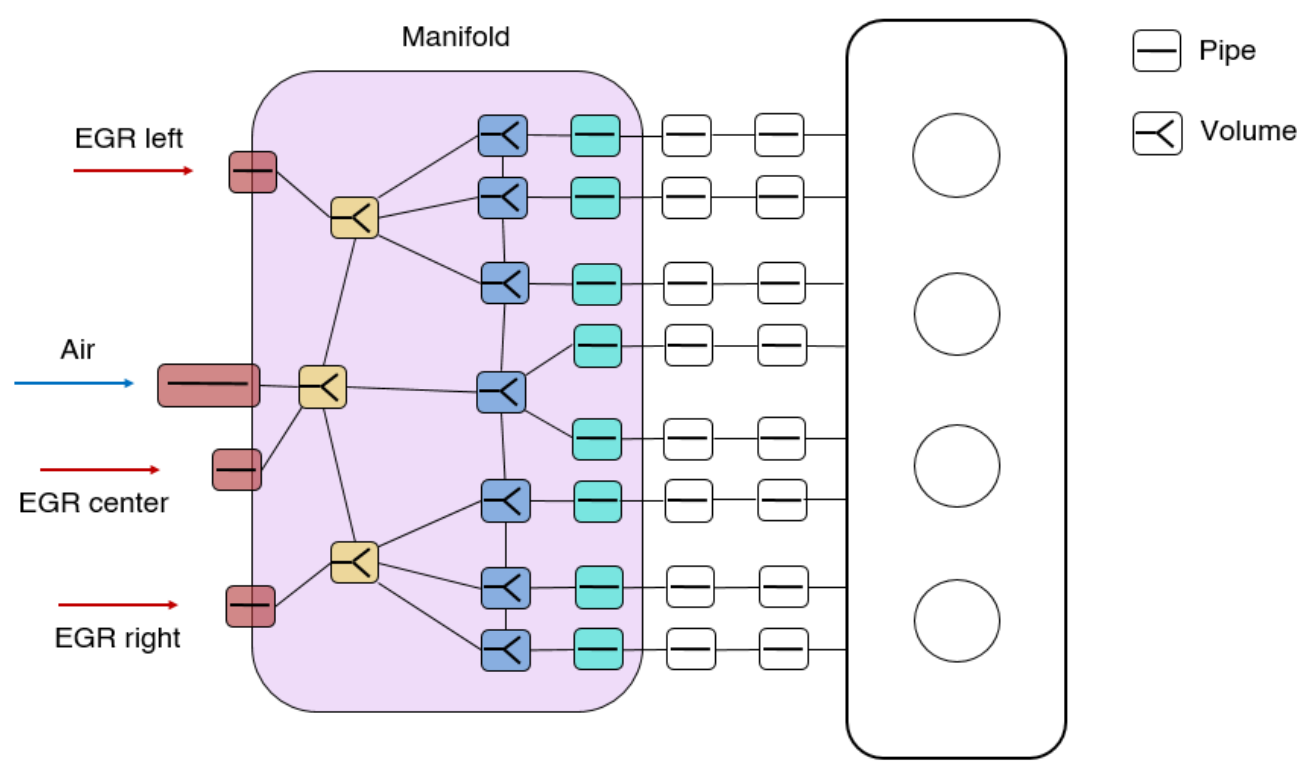

Figure 3.15 Schema of the intake manifold in the model.

The combustion profile inside the cylinders is essential to perform a realistic and predictor model. Because of that, the first task was to make one combustion profile for each engine running conditions. The experimental inlet cylinder pressure is required to adjust the combustion profile on the model. Moreover, it is necessary to know the timing of the injection and the fuel mass injected [113].

The model solves the Navier-Stokes equation in its 1D version and employs a finite-volume method. In the pipes, the mass and energy conservation equations are solved in the center of the finite-volumes and the momentum conservation equation is solved at the boundaries between the finite-volumes. The model assumes that the section of the pipes is round by default. However, it is possible to correct the effect of the round section modifying some parameters like the friction multiplier, the heat-transfer multiplier and the pressure loss coefficient, trying to become the round section closer to the real section characteristics. In addition, the length and the cross sectional area is the same in both cases. 
The friction multiplier scales the friction loses calculated at each pipe. The friction loses are calculated by the Fanning friction factor which depends of the Reynolds number (Re) and wall surface roughness. Therefore, this factor is implied in the momentum equation. The relationship among the Reynolds number, wall roughness and the resulting friction factor is described by the Moody Diagram and mathematically expressed by Colebrook equation [114]. Nevertheless, in order to improve the solution speed, the model uses an approximation of the Colebrook equation. In addition, according to the preferences of the user (speed or accuracy), the model offers two different options to calculate the friction losses. For laminar regime the Fanning friction factor is calculated similarly for both methods, like is expressed in Eq. 3.9 [115]:

$$
C_{f}=\frac{16}{R e}
$$

Where $C_{f}$ the Fanning friction factor and Re is the Reynolds number. For turbulent regime the first method is faster but less accurate. The fast method calculates the friction factor when the roughness of the pipes is declared 0 with Eq. 3.10 developed by Blasius:

$$
C_{f}=\frac{0.08}{R e^{0.25}}
$$

On the other hand, when the roughness is declared higher than 0 , the Nikuradse equation [116] is applied:

$$
C_{f}=\frac{0.25}{\left(2 \log _{10}\left(\frac{1}{2} \frac{D}{\varepsilon}\right)+1.74\right)^{2}}
$$

Where $\varepsilon$ is the roughness of the wall pipe and D is the diameter of the pipe. The roughness is determined by the material selected to the pipe.

The friction factor is calculated by a linear interpolation between the laminar and turbulent values in the transition regime.

The accurate method is slower but it deviates from the Colebrook equation less than the fast method. This method employs the Serghides approximation [117] to the Colebrook equation for any roughness value: 


$$
C_{f}=\frac{1}{4}\left(4.781-\frac{(A-4.781)^{2}}{B-2 A+4.718}\right)^{-2}
$$

Where:

$$
\begin{aligned}
& A=-2 \log _{10}\left(\frac{\varepsilon / D}{3.7}+\frac{12}{R e}\right) \\
& B=-2 \log _{10}\left(\frac{\varepsilon / D}{3.7}+\frac{2.51 A}{R e}\right)
\end{aligned}
$$

Like in the fast method, the friction factor is interpolated between the laminar and accurate value for transition regime.

Additionally, the pressure losses are calculated separately from the friction losses. The pressure loss coefficient $\left(h_{f}\right)$ estimates the pressure loss due to irregular geometries like bends and it is calculated as follows:

$$
h_{f}=\frac{p_{1}-p_{2}}{\frac{1}{2} \rho V_{1}^{2}}
$$

Where $p_{1}$ and $p_{2}$ represent inlet and outlet total pressure respectively, $\rho$ symbolizes the inlet density and $V_{1}$ correspond to the inlet velocity. Nevertheless it is possible to enter a numerical value as $h_{f}$ if it is necessary, instead of allowing the software to calculate it. On the other hand there is the possibility to impose the value that the user wants.

The heat transfer from the fluids to the walls is calculated by a heat transfer coefficient that is calculated from the fluid velocity, the thermos-physical properties and the wall surface roughness. For the smooth pipes the heat transfer coefficient is calculated using the Colburn analogy as follows:

$$
h_{g}=\frac{1}{2} C_{f} \rho U_{e f f} C_{p} P r^{(-2 / 3)}
$$

Where $h_{g}$ is the heat transfer coefficient, $\rho$ is the density, $U_{\text {eff }}$ represents the effective velocity outside boundary layer, $C_{p}$ corresponds to the specific heat and $\operatorname{Pr}$ symbolizes the Prandtl number.

The total heat transfer is calculated by the heat transfer coefficient, the predicted fluid temperature and the wall temperature. In this way, the wall temperature 
defined could be an initial value if the wall temperature is calculated or it could be a fixed value throughout the simulation.

In this case the temperature of the walls was calculated. The environmental heat transfer is calculated by the definition of the external convection coefficient, temperature and radiation. The model used the heat transfer from the fluids into the pipes and environmental heat transfer, the thermal capacity of the walls and the initial temperature to start the calculation of the wall temperatures. The thermal capacity depends on the material. Some parameters like conductivity, density and specific heat must be defined.

The situation to the volumes is very similar, but with various pipes attaching the volume, so more than two orifices (inlet and outlet) like in pipes. The scalar equations (mass and energy) are calculated inside the volume too (i.e. the finite volume that make up the volume without the attaching pipes). On the other hand, the momentum conservation is calculated separately in the junctions between the volume and the pipes.

Owing to the model takes into account the boundary angles of the pipes that attach the volume, the 3-dimensions are considered in the momentum conservation, although the equations are solved in their 1D form. In this way operates the quasi-3D effect. In addition, to the momentum solution, the model takes into account the expansion diameter which the flow expands after enter into the volume, and the characteristic length, $i$. e. the distance from the boundary to the opposite side of the volume. The process is much more accurate according to a complex geometry when the intake manifold is performed by the software and not manually. Moreover, a characteristic velocity vector is calculated inside the volume taking into account the momentum from all the boundaries. And, out of the volume, the momentum is calculated with the characteristic velocity in the direction of the boundary.

The friction, heat transfer and walls temperature are calculated like in pipes, excepting that the velocities employed are acquired by the weighted boundary velocities.

The heat transfer coefficient into the cylinder is defined by the Woschni model like is showed in Eq. 3.17: 


$$
h_{c y l}=3.26 B^{-0.2} P^{0.8} T^{-0.53} w^{0.8}
$$

Where $\mathrm{B}$ represents the cylinder bore, $\mathrm{P}$ is the cylinder pressure, $\mathrm{T}$ corresponds to the cylinder temperature and $\mathrm{w}$ symbolizes the average cylinder gas velocity. In addition, it is possible to define heat transfer multipliers to adjust the calibration of the model.

Like before in pipes and volumes, the wall temperature is calculated by the model, with a finite element method, thanks to geometry information of the cylinder and boundary conditions related to the coolant and oil temperature.

The materials of each component of the engine and the heat transfer coefficients must be loyal to reality. It is necessary to adjust the pressure and the temperature in the exhaust. The geometry of the manifolds, exhaust line, intake line and EGR line must be performed according to reality: lengths, diameters, materials and heat exchangers. A multiplier for the heat transfer coefficient inside the cylinders, pipes and volumes, friction multipliers for pipes and volumes, the inertia of the turbocharged and the compressor and turbine efficiencies are useful to calibrate methodically the model $[2,118]$.

The four operation points of the preliminary study, showed in Table 3.5, were used to calibrate the model (taking into account the nominal values of the EGR, not in parentheses). In addition, a recalibration was necessary to model the working operation points of the detailed study due to the modifications suffered by the intake manifold and the EGR line (including the regulation valves).

\subsection{Metrics definition}

First of all a typical statistic variable is used as indicator of the HP EGR dispersion level in this study, the standard deviation. This variable applied to the EGR is defined following the next expression:

$$
\sigma_{E G R}=\sqrt{\frac{\sum_{i=1}^{n}\left(x_{i}-\bar{x}\right)^{2}}{n}}
$$


Where:

$\mathrm{i}=$ the number of the cylinder.

$\mathrm{n}=4$ (total number of cylinders).

$\mathrm{x}_{\mathrm{i}}=$ the average $\mathrm{CO}_{2}$ concentration in cylinder $\mathrm{i}$.

$\bar{x}=$ the average $\mathrm{CO}_{2}$ concentration in the 4 cylinders.

Furthermore, the coefficient of variance is necessary to normalize the standard deviation. The coefficient of variance is obtained dividing the standard deviation by the average as represented by the next expression:

$$
\operatorname{COV}=\frac{\sqrt{\frac{\sum_{i=1}^{n}\left(x_{i}-\bar{x}\right)^{2}}{n}}}{\bar{x}}
$$

Regarding the comparison between modeling and experimental results, it is necessary to look a variable that can help to show the information in a clear and simple way, due to the high number of variables (the EGR rate in each intake pipe and 39 tests to compare). The root mean squared error, which is a value commonly used to compare modeling and experimental results, is a proper parameter to be used in this study. It results from the simple addition of the differences in all the cylinders to the square (in order to avoid that negative errors would decrease the global error). Additionally, like before, it is necessary to normalize this value to compare different engine running conditions. Because of that reason, the non-dimensional root mean squared error (ndRMSE) is defined dividing the root mean square error by the average of the experimental EGR rate as the following expression shows:

$$
n d R M S E=\frac{\sqrt{\sum_{i=1}^{n}\left(x_{i, \bmod }-x_{i, \exp }\right)^{2} / n}}{\bar{x}_{\exp }}
$$

Where $\mathrm{n}$ is the number of cylinders, $\mathrm{i}$ denotes the cylinder, subscripts mod and exp indicate model and experiment, respectively, and $\bar{x}$ is the average of all the cylinders. Since the HP EGR dispersion analysis should be evaluated in the cylinders, where the combustion process takes place, the comparison between experiments and model is performed from a cylinder point of view and not 
from an intake pipe perspective. The calculation of the EGR rate in the cylinders is carried out by averaging the values from the two corresponding intake pipes. The ndRMSE is a non-dimensional value but in the following analysis it is expressed in percentage format.

Together with the non-dimensional RMSE, simple comparisons can be made from a cylinder perspective, which will lead to an additional metric: the difference between the model and the experiment from all the pipes for a given running condition. This metric can be calculated: (a) in absolute terms, whose unit will be percentage points of EGR level (absolute error), and (b) in relative terms if we compute the difference divided by the value given by the experiments, whose unit will be percentage (relative error).

The ndRMSE, absolute error (AE) and relative error (RE) compare predicted and measured results, while the metrics defined in the following paragraphs can be applied to either the model or the experimental data. They do not provide any information about the performance of the model but can be useful to analyze the spatial pattern of the EGR dispersion among cylinders. The standard deviation and the coefficient of variance, defined before, can be computed to evaluate the differences in the pipes related to the average value. Other metrics are defined in the next lines.

A symmetry factor SF [119] can be defined taking into account that every pipe from 1 to 4 will have a geometrical opposed pipe, from pipe 8 to 5 . Hence, this factor is defined as:

$$
S F=\sum_{i=1}^{4} \frac{\left(x_{i}-x_{9-i}\right)^{2}}{\bar{x}^{2}}
$$

Where the subscript refers to the number of the intake pipe. Again, the differences are computed to the square to avoid the cancellation between positive and negative differences. The symmetry factor is always a positive value and it provides values close to zero when the spatial profile of the EGR dispersion is symmetric. The higher the SF value, the more asymmetric spatial pattern is found. 
Finally, another metric to evaluate the shape of the spatial distribution of the results in the pipes (either predicted or measured) is the convexity factor (CF) [119] given by Eq. (3.21):

$$
C F=\sum_{i=2}^{7}\left(x_{i}-\frac{\left(x_{i+1}+x_{i-1}\right)}{2}\right) \cdot \frac{1}{\bar{x}}
$$

Where, again, the subscript relates to the intake pipe. While the other metrics provided scalars greater than zero, the CF can be a positive or a negative number. An inspection of the previous expression would lead to conclude that flat spatial EGR distributions in the pipes provide convexity factors close to zero, while positive values indicate a convex distribution (i.e. higher values in the central pipes) and negative values mean concave profiles (i.e. higher values in the pipes located in the extremes) [2].

A quantitative example is provided in Figure 3.16 to illustrate how the SF and CF work. The numbered columns showed the EGR rate per pipe from 1 to 8 (so, from cylinder 1 to 4 ). In the first example is observed that the EGR profile among the pipes perfectly symmetric because there is the same EGR rate in opposite pipes $(1-8,2-7$, etc.) In addition, the EGR rate is higher in the center and lower in the extremes, so it is a convex profile. Therefore, in this case, the SF is 0 , because it is perfectly symmetric and the CF is positive $(0.15)$ because the profile is convex. In the second case, the profile is asymmetric, due to the EGR rate in the opposite pipes is very different. Moreover, the EGR rates are higher in the extremes than in the center, so now the profile is concave. Consequently, the SF is high, because it is asymmetric, and the CF is negative, because the distribution is concave. 

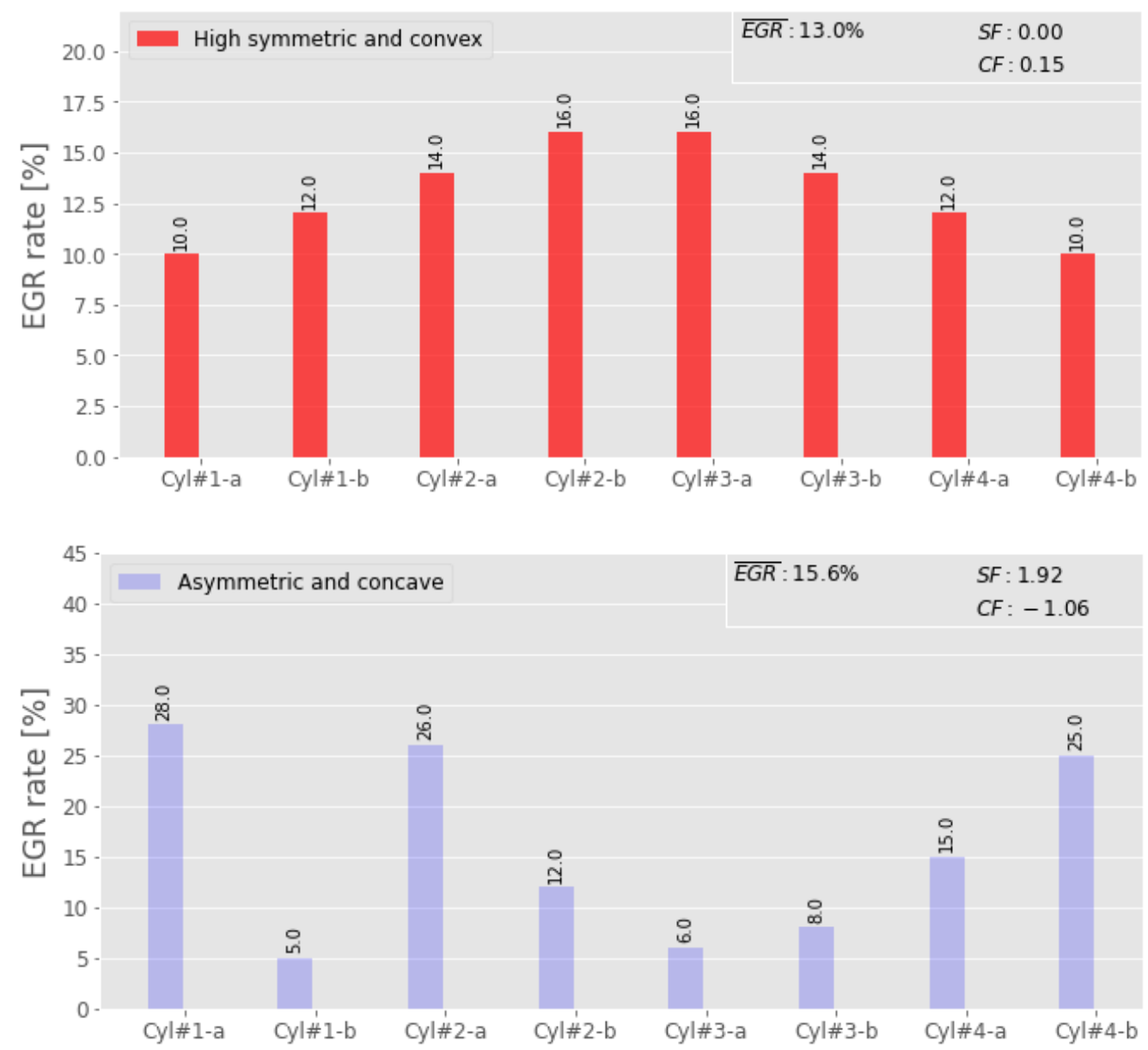

Figure 3.16 Quantitative example of SF and CF. 


\section{Chapter 3 Bibliography}

[1] V. Macián, J. M. Luján, H. Climent, J. Miguel-García, S. Guilain, and R. Boubennec. "Cylinder to cylinder high-pressure exhaust gas recirculation dispersion effect on opacity and NOx emissions in a diesel automotive engine". International Journal of Engine Research (2020). URL: https://doi.org/10.1177/1468087419895401 (cit. on pp. xv, 5, 73, 138, 184).

[2] J. Galindo, H. Climent, R. Navarro, J. Miguel-García, D. Chalet, and P-E Pretot. "A study on the high pressure EGR transport and application to the dispersion among cylinders in automotive engines". International Journal of Engine Research (2020). URL: https://doi.org/10.1177/1468087420969263 (cit. on pp. xv, 6, 84, 87, 172, 186).

[3] J. M. Luján, H. Climent, F. Aranu, and J. Miguel-García. “Analysis of low pressure exhaust gases recirculation control in transient operation of automotive diesel engines". Applied Thermal Engineering 137 (2018), pp. 184192. URL: https://doi.org/10.1016/j.applthermaleng.2018.03.085 (cit. on pp. xvii, $33,59)$.

[14] R. M. Siewert, R. B. Krieger, M. S. Huebler, P. C. Baruah, B. Khalighi, and M. Wesslau. "Modifying and Intake Manifold to Improve Cylinder-to-Cylinder EGR Distribution in a DI Diesel Engine Using Combined CFD and Engine Experiments". 2001 SAE Technical Paper 2001-01-3685. URL: http://dx.doi.org/10.4271/2001-01-3685 (cit. on pp. 5, 40, 67, 187).

[15] A. Maiboom, X. Tauzia, and J-F. Hétet. "Influence of EGR unequal distribution from cylinder to cylinder on NOx-PM trade-off of a HSDI automotive Diesel engine". Applied Thermal Engineering 29 (2009), pp. 20432050. DOI: 10.1016/j.applthermaleng.2008.10.017 (cit. on pp. 5, 40, 67, 187).

[73] M. Hernández. "A non-linear quasi-3D model for air management modelling in engines". Doctoral Thesis (2018) (cit. on pp. 34, 35, 36, 37, 38, 39, $40,78,187)$. 
[76] D. E. Winterbone and R. J. Pearson. "Theory of engine manifold design: wave action methods for IC engines". Wiley-Blackwell (2000) (cit. on pp. 35, 36, $37,38,39,74)$.

[102] A. J. Torregrosa, A. Broatch, F. J. Arnau, and M. Hernández. "A non-linear quasi-3D model with Flux-Corrected-Transport for engine gas-exchange modelling". Journal of Computational and Applied Mathematics 291 (2016), pp. 103-111. DOI: 10.1016/j.cam.2015.03.034 (cit. on pp. 39, 78, 187).

[106] W. P. Partridge, S. A. Lewis, M. J. Ruth, G. G. Muntean, R. C. Smith, and J. H. Stang. "Resolving EGR Distribution and Mixing". 2002, SAE Technical Paper 2002-01-2882. URL: http://dx.doi.org/10.4271/2002-01-2882 (cit. on pp. 40, $67,187)$.

[109] J. M. Luján, H. Climent, B. Pla, M.E. Rivas-Perea, N-Y. François, J. BorgesAlejo, and Z. Soukeur. "Exhaust gas recirculation dispersion analysis using incylinder pressure measurements in automotive diesel engines". Applied Thermal Engineering 89 (2015), pp. 459-468. URL: https://doi.org/10.1016/j.applthermaleng.2015.06.029 (cit. on pp. 41, 67, 187).

[110] J. M. Luján, H. Climent, L. M. García-Cuevas, and A. Moratal. “Volumetric efficiency modelling of internal combustion engines based on a novel adaptative learnig algorithm of artificial neural networks". Applied Thermal $\begin{array}{lllll}\text { Engineering } & 123 & \text { (2017), } & \text { pp. 625-634. URL: }\end{array}$ https://doi.org/10.1016/j.applthermaleng.2017.05.087 (cit. on p. 73).

[111] J. Galindo, J. R. Serrano, F. J. Arnau, and P. Piqueras. "Description of a Semi-Independent Time Discretization Methodology for a One-Dimensional Gas Dynamics Model". ASME. J. Eng. Gas Turbines Power 131 (3):034504 (2009). URL: https://doi.org/10.1115/1.2983015 (cit. on p. 74).

[112] J. R. Serrano, H. Climent, P. Piqueras, and O. García-Alfonso. "Analysis of shock capturing methods for chemical species transport in unsteady compressible flow". Mathematical and Computer Modelling 57 (7-8) (2013), pp. 1751-1759. DOI: 10.1016/j.mcm.2011.11.026 (cit. on p. 77). 
[113] L. Kaprielian. "Modélisation 0D pour la combustion dans les moteurs à allumage commandé : développements en proche paroi et dans le front de flamme". PhD Thesis, Arts et Métiers Paris Tech, 2015 (cit. on p. 80).

[114] C. F. Colebrook. "Turbulent Flow in Pipes, with Particular Reference to the Transition Region between the Smooth and Rough Pipe Laws". Journal of the Institution of Civil Engineers 11 (1939), pp. 133-156 (cit. on p. 81).

[115] R. B. Bird, E. N. Lightfoot, and W. E. Stewart. "Transport phenomena". (2007) (Wiley, New York/Toronto) (cit. on p. 81).

[116] J. Nikuradse. "Stromungsgesetze in rauhen Rohren". VDI-Forschungsheft 361 (1933), p. 1 (cit. on p. 81).

[117] T. K. Serghides. "Estimate friction factor accurately". Chemical Engineering 91 (5) (1984), pp. 63-64 (cit. on p. 81).

[118] D. Chalet, M. Lesage, M. Cormerais, and T. Marimbordes. "Nodal modelling for advanced thermal-management of internal combustion engine". Applied Energy 190 (2017), pp. 99-113. DOI 10.1016/j.apenergy.2016.12.104 (cit. on p. 84).

[119] J. Galindo, H. Climent, R. Navarro, G. García-Olivas, S. Guilain, and R. Boubennec. "Effect of Numerical Configuration on Predicted EGR Cylinder-toCylinder Dispersion". SAE Technical Paper 2020-01-1113, 2020. DOI: 10.4271/2020-01-1113 (cit. on pp. 86, 87). 

"I had a hard job getting it right, but the finished result is beyond my wildest dreams."

Colin in Froth on the Daydream by Boris Vian

\section{Chapter 4}

\section{Results and discussion}





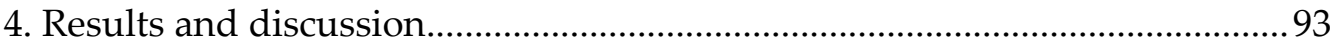

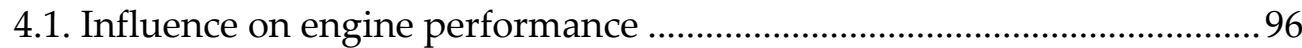

4.1.1. Determination of the reasonable EGR dispersion levels ...................96

4.1.2. Assessment of constant input values ................................................... 101

4.1.3. Influence on opacity of exhaust gases ............................................... 108

4.1.4. Influence on fuel consumption.......................................................... 121

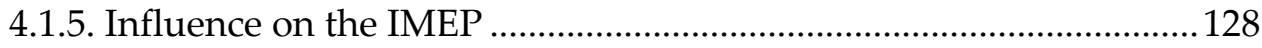

4.1.6. Influence on the exhaust gases composition .................................... 130

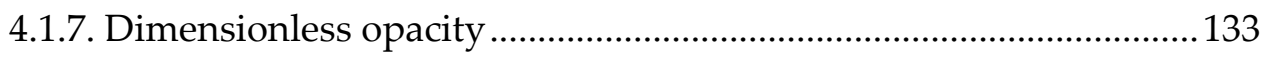

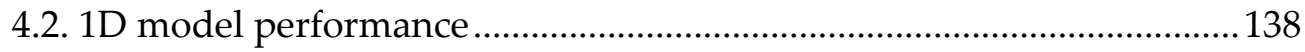

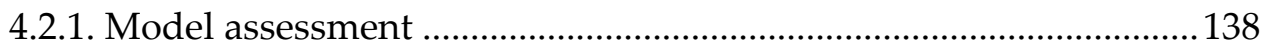

4.2.2. Influence of the manifold layout modeling ..................................... 143

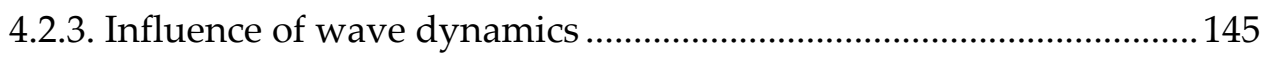

4.2.4. Influence of the size of the manifold ................................................... 153

4.2.5. Results with controlled EGR dispersion ...........................................156

4.2.6. Model sensitivity to EGR rate variations ........................................... 163

4.2.7. 1D engine model performance ......................................................... 168

Chapter 4 Bibliography …………................................................................ 177 


\subsection{Influence on engine performance}

Once the experimental setup and the experimental tools have been explained, the metrics have been defined and the methodology has been detailed, it is possible to analyze and discuss the results in terms of engine performance, emissions and HP EGR dispersion levels.

\subsubsection{Determination of the reasonable EGR dispersion levels}

Initially 4 engine running conditions were selected to perform the preliminary study. The objective was to determine the HP EGR dispersion levels at different engine running conditions with conventional devices (i.e. mixers) in the intake manifold and the HP EGR line discharge. The engine running conditions were already described in Table 3.5 in Chapter 3, where the preliminary study was detailed.

Figure 4.1 presents the engine map where it is possible to check the engine running conditions regarding to load and EGR rate level. The Y-axis represents the torque in $\mathrm{Nm}$, the $\mathrm{X}$ - axis represents the speed in rpm and the color bar indicates the EGR rate in percentage.

It is possible to see how the higher EGR rates, around 50\%, are concentrated between 1400 and $2200 \mathrm{rpm}$ and under $100 \mathrm{Nm}$ of torque. However, between 2000 and $3000 \mathrm{rpm}$ there is a high EGR rate space between 25 and $40 \%$. It is not so high as the first area, but it is significantly high and entail an expansion of the EGR rate influence area when comparing with the first engines with EGR strategy. It is a consequence of the tightening regulations to reduce the NOx emissions. Finally, there is a reduction in EGR rate from medium load to high load where the EGR rate decreases until $0 \%$ at full load. On one hand, the engine running conditions selected at $1500 \mathrm{rpm}$ correspond to very low load, the first of them presents a very high EGR rate, and the other presents a low EGR rate respectively. On the other hand, the engine running conditions selected at 2500 rpm are medium and high load respectively, the first one presents a medium EGR rate and the second one presents a low EGR rate. 


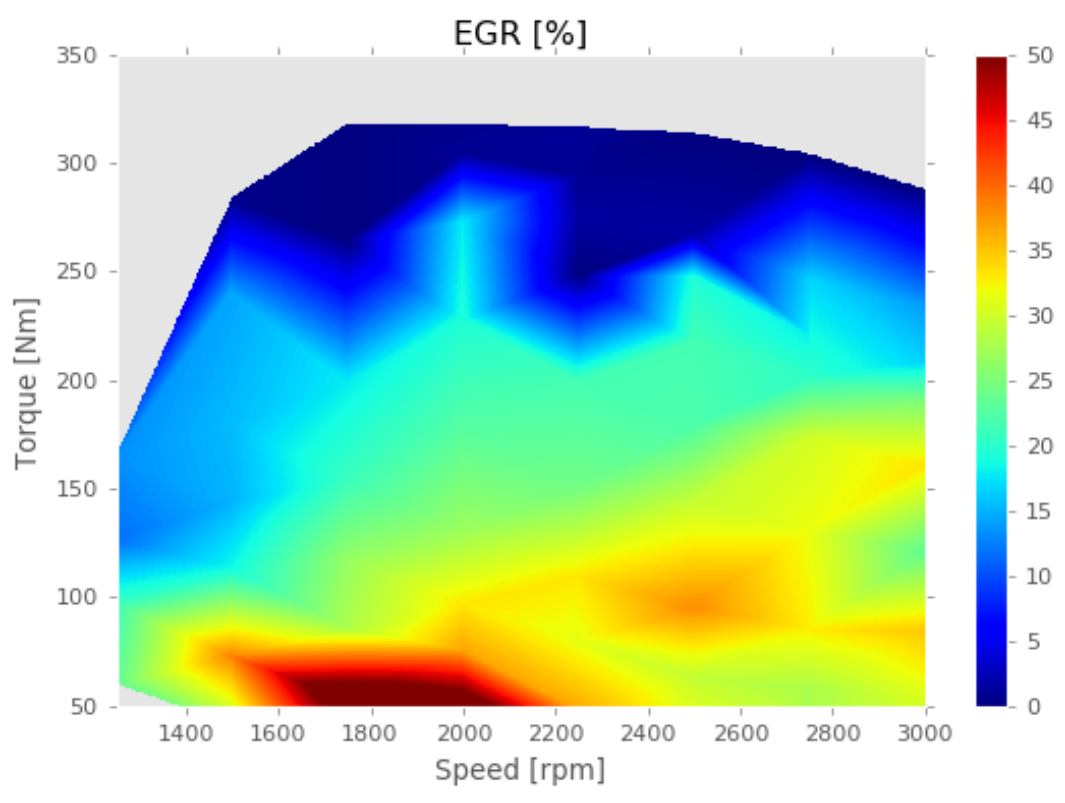

Figure 4.1. Engine map. X-axis represents the engine speed, $\mathrm{Y}$-axis represents the engine torque and color bar represents the EGR rate.

Figure 4.2 presents the HP EGR dispersion at 1500-01, 1500-03, 2500-10 and 2500-19 working operation points with mixer 1 (being the first number the engine speed and the second one the BMEP). X-axis represents the intake pipe number and $\mathrm{Y}$-axis represents the EGR rate in percentage. It is possible to observe at first sight how the running conditions with lower EGR rate offer higher standard deviation values and the running conditions with higher EGR rate offer lower standard deviation values. It is especially striking the highest EGR rate case, 1500-01, which offers not significant differences among pipes, so the dispersion in this case is close to zero. Moreover, it is possible to see a trend, in most cases, of a predominant entrance of the EGR to the cylinders through the pipes situated in the center. 

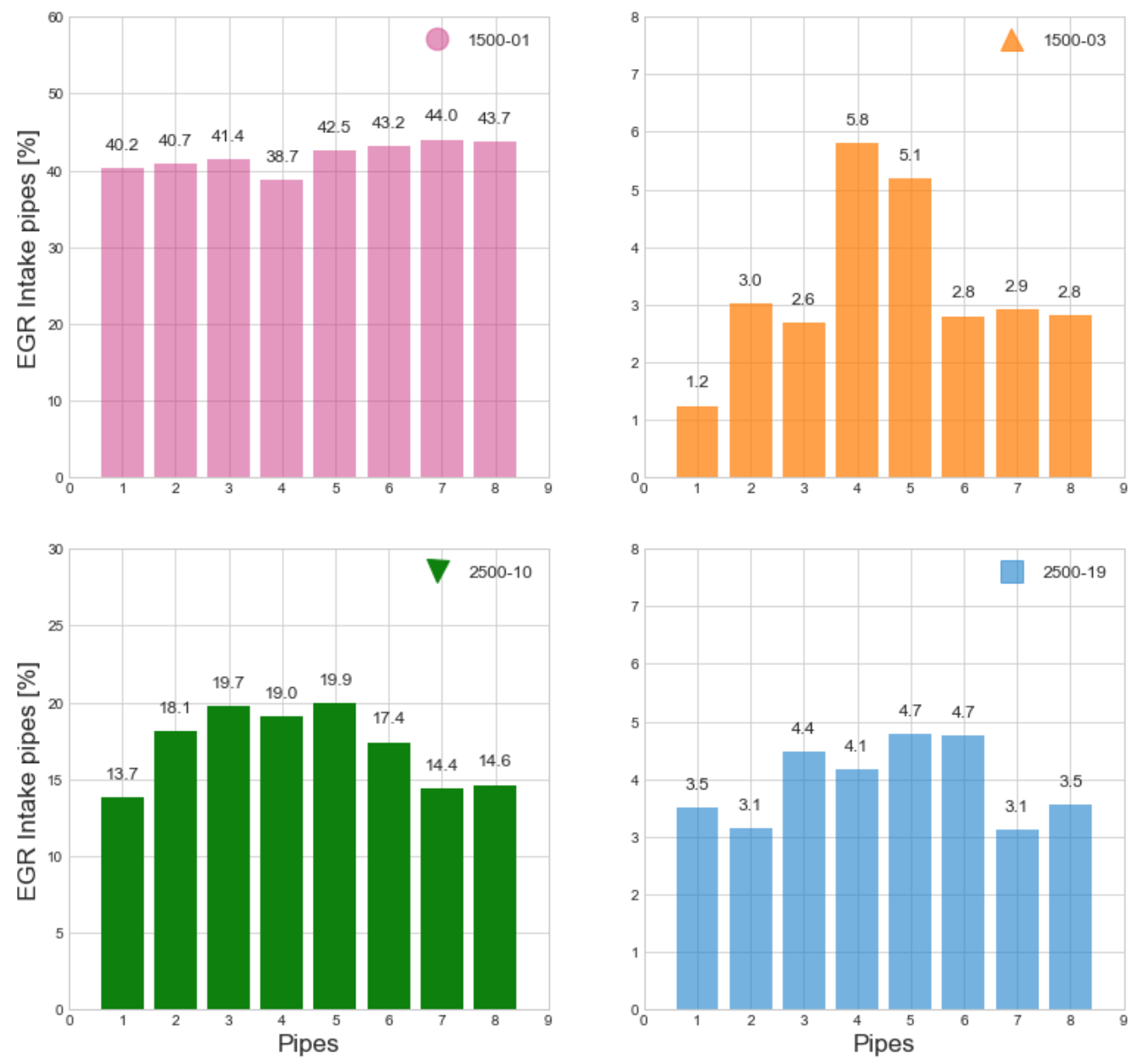

Figure 4.2. EGR rate intake pipes values vs. pipes at 1500-01, 1500-03, 2500-10 and 2500-19 from left to right and from top to bottom, all of them performed with mixer 1.

Figure 4.3 shows the HP EGR dispersion at 1500-01, 1500-03, 2500-10 and 250019 working operation points with mixer 2 . Once again, $X$-axis represents the number of the pipes and $\mathrm{Y}$-axis represents the EGR rate in percentage. It is possible to observe how a proper orientation of the entrance of the EGR reduces considerably the EGR standard deviation in some cases, especially in the worst case with mixer 1, 1500-03. Moreover, it is possible to observe an opposite trend to the previous in the entrance to the cylinders. The EGR enters to the cylinders more easily through the pipes situated in the sides with mixer 2 than with mixer 1 due to the orientation of the EGR, leaned backwards, towards the air inlet. 

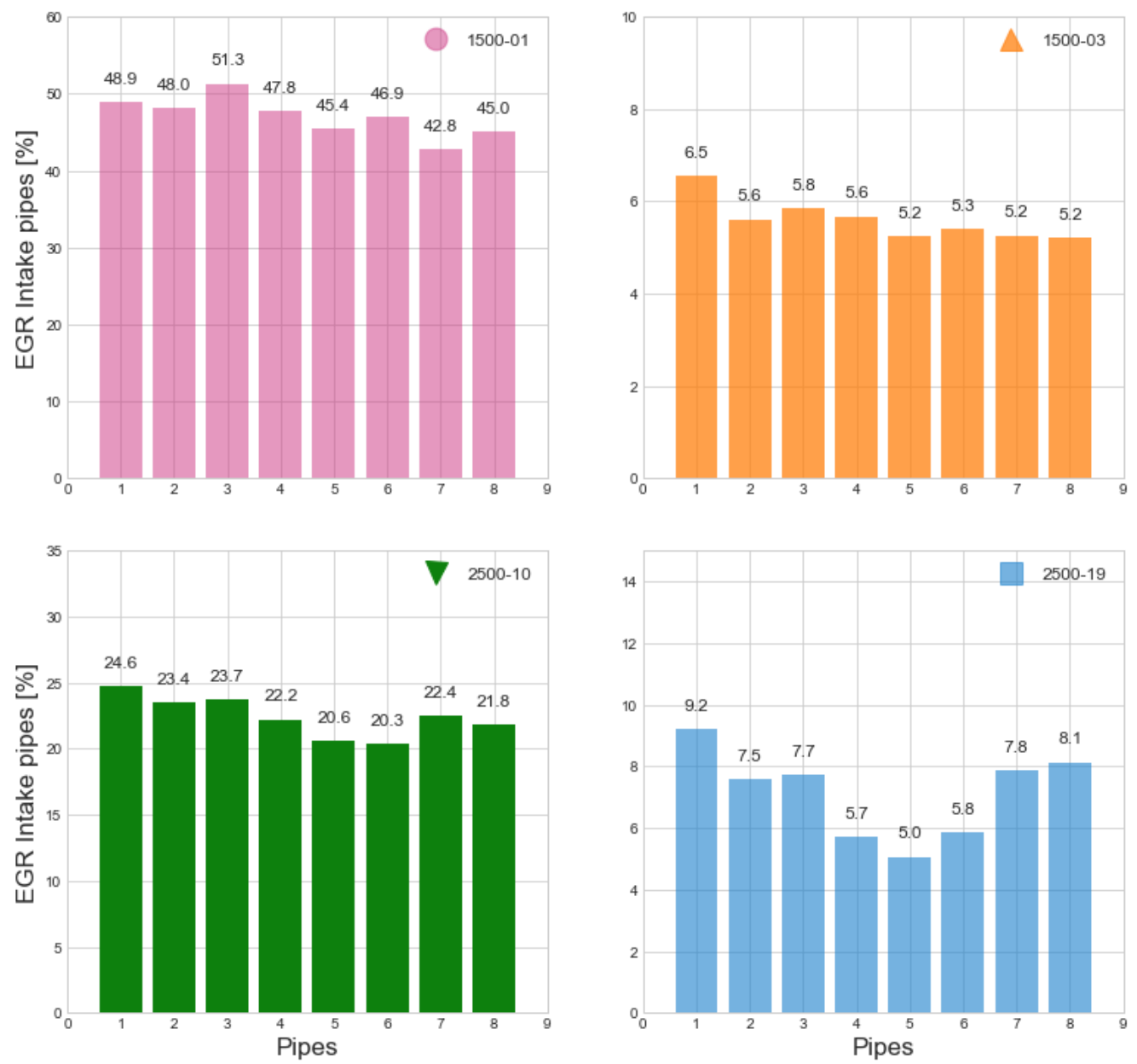

Figure 4.3. EGR rate intake pipes vs. pipes at 1500-01, 1500-03, 2500-10 and 250019 from left to right and from top to bottom, all of them performed with mixer 2.

In Figure 4.4 the HP EGR dispersion at 1500-01, 1500-03, 2500-10 and 2500-19 working operation points with mixer 3 is presented. It is possible to observe how an improperly orientation of the entrance of the EGR increases considerably the EGR standard deviation and the EGR is deflected to the side of the intake manifold where the mixer is oriented, to cylinders 3 and 4 in this case. 

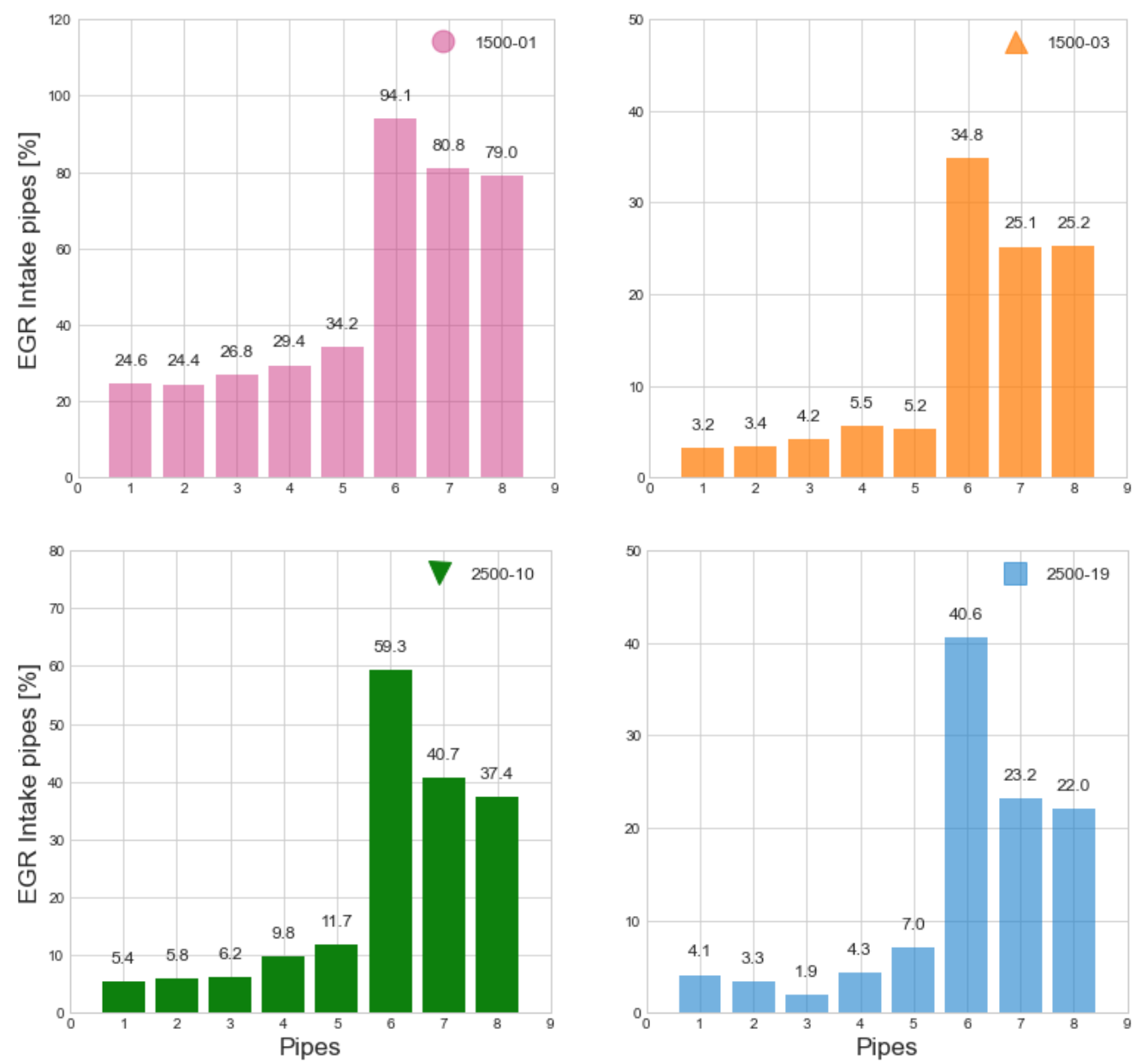

Figure 4.4. EGR rate intake pipes vs. pipes at 1500-01, 1500-03, 2500-10 and 250019 from left to right and from top to bottom, all of them performed with mixer 3.

Figure 4.5 shows the EGR dispersion at 1500-01, 1500-3, 2500-10 and 2500-19 engine running conditions with mixer1, mixer2 and mixer 3. Y-axis represents the coefficient of variance and $X$-axis represent the mixer employed. First of all, it is possible to see a high difference between mixers 1 and 2 , and mixer 3 . While mixers 1 and 2 show COV values under 0.3 , mixer 3 shows COV values between 0.4 and 0.8 due to the asymmetric orientation of the altered design of the mixer 3. 
Furthermore, it is remarkable that, on the one hand, the highest EGR rate case is, for all mixers, the best case regarding EGR distribution among cylinders considering that it presents the lowest COV value. On the other hand, the two lowest EGR rate cases are the worst cases regarding EGR distribution as they present the highest COV values, 1500-03 in mixer 1 and 2500-10 in mixers 2 and 3. This effect is consequence of the jet penetration that benefits a better distribution due to the vortex effect and the turbulence generated by the impact as J. Williams et al. exposed in 2003 [120].

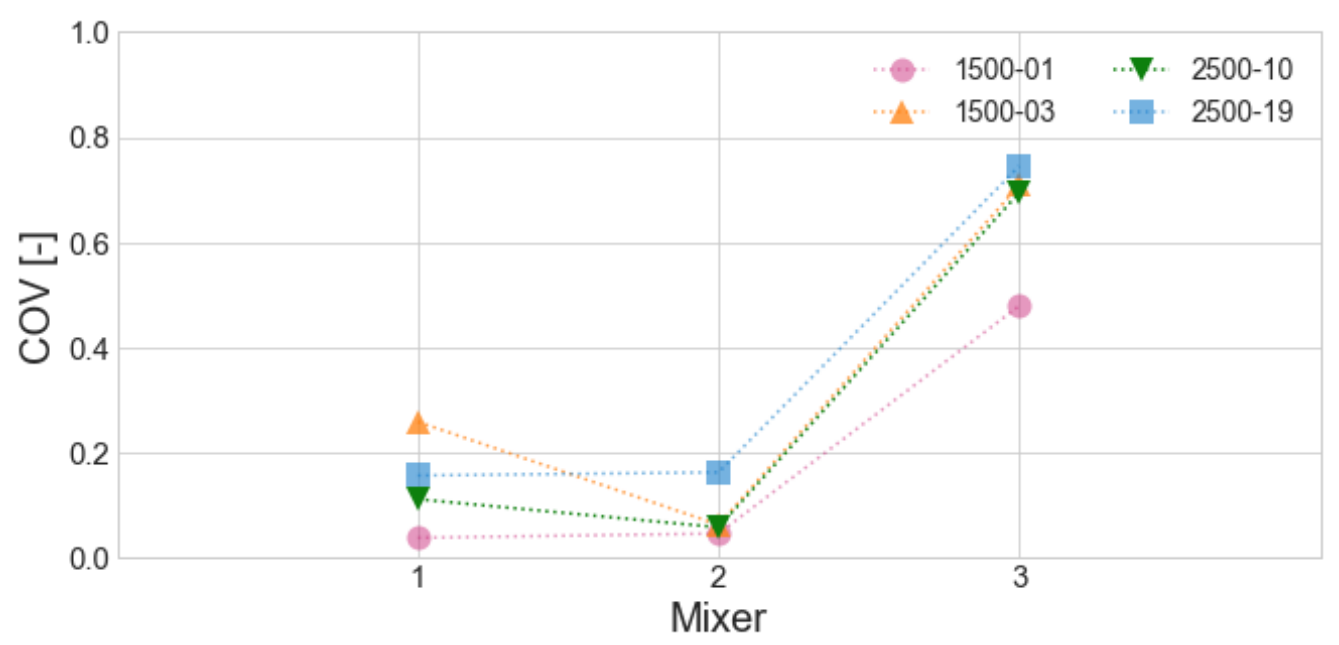

Figure 4.5. Coefficient of variance of the EGR rate among cylinders vs mixers at 1500-01, 1500-03, 2500-10 and 2500-19.

\subsubsection{Assessment of constant input values}

Once the influence of the geometry on EGR dispersion has been observed and partially quantified in conventional mixers designs, it is necessary to do a wider selection of engine running conditions and perform engine tests with the system described in Chapter 3 that allowed the modification of the EGR dispersion with the actuation of three regulation valves. The new engine running conditions to perform a detailed study about the influence of the EGR dispersion over the exhaust emissions, principally NOx and smoke, were presented in Table 3.6 in Chapter 3.

Paying attention to the engine map showed in Figure 4.1 it is possible to observe that a large area of it is covered. The low speed 1250 and $1500 \mathrm{rpm}$ running 
conditions at high load and with low EGR rates, the medium speed 2000 and $2500 \mathrm{rpm}$ running conditions at low and medium load respectively and medium EGR rate and, finally, the high speed $3000 \mathrm{rpm}$ running conditions at high load and medium-low EGR rate.

In addition, 1250 and $1500 \mathrm{rpm}$ engine running conditions worked at high load with low margin to increase the EGR rate. Therefore, the EGR standard deviation range is conditioned, because with higher EGR standard deviation, some cylinders must to take higher EGR rates and they do not accept it and the engine shuts off the fuel injection and opens the turbine to reduce the load degree of the engine. Hence, the range of the EGR standard deviation explored at 1250 and $1500 \mathrm{rpm}$ is lower than the others precisely because the conditions were critical and the performance did not have margin to force higher EGR dispersion. Consequently, many parameters show not significant changes among cases at 1250 and $1500 \mathrm{rpm}$. Although, the opacity increases significantly at that engine running conditions.

In Figure 4.6 it is possible to observe the intake manifold pressure on the left and the engine torque on the right, both of them related to the nominal value presented in Table 3.6. The X-axis represents the standard deviation of the EGR expression defined in section 3.3 "Metrics definition" in Chapter 3. It is possible to observe in the graph on the right the legend of the working operation points. The numbers represent the position of the three regulation valves of the EGR, where $0 \%$ means that it is completely closed and $100 \%$ is completely open. The number on the left represents the left valve before the manifold (in the sense of the flow), the number in the center represents the center valve and the number in the right represents the right valve, as depicted in Figure 3.10.

Over the symbols, the EGR rate in each test is shown. It is possible to see that all of them are under 3\% of variation, in both variables, intake manifold pressure and engine torque. In summary, during the testing campaign, although the HP-EGR dispersion was modified, all the tests were performed keeping nearly constant values of intake manifold pressure (by fine tuning the VGT opening) and engine torque (by modifying the injected fuel). 

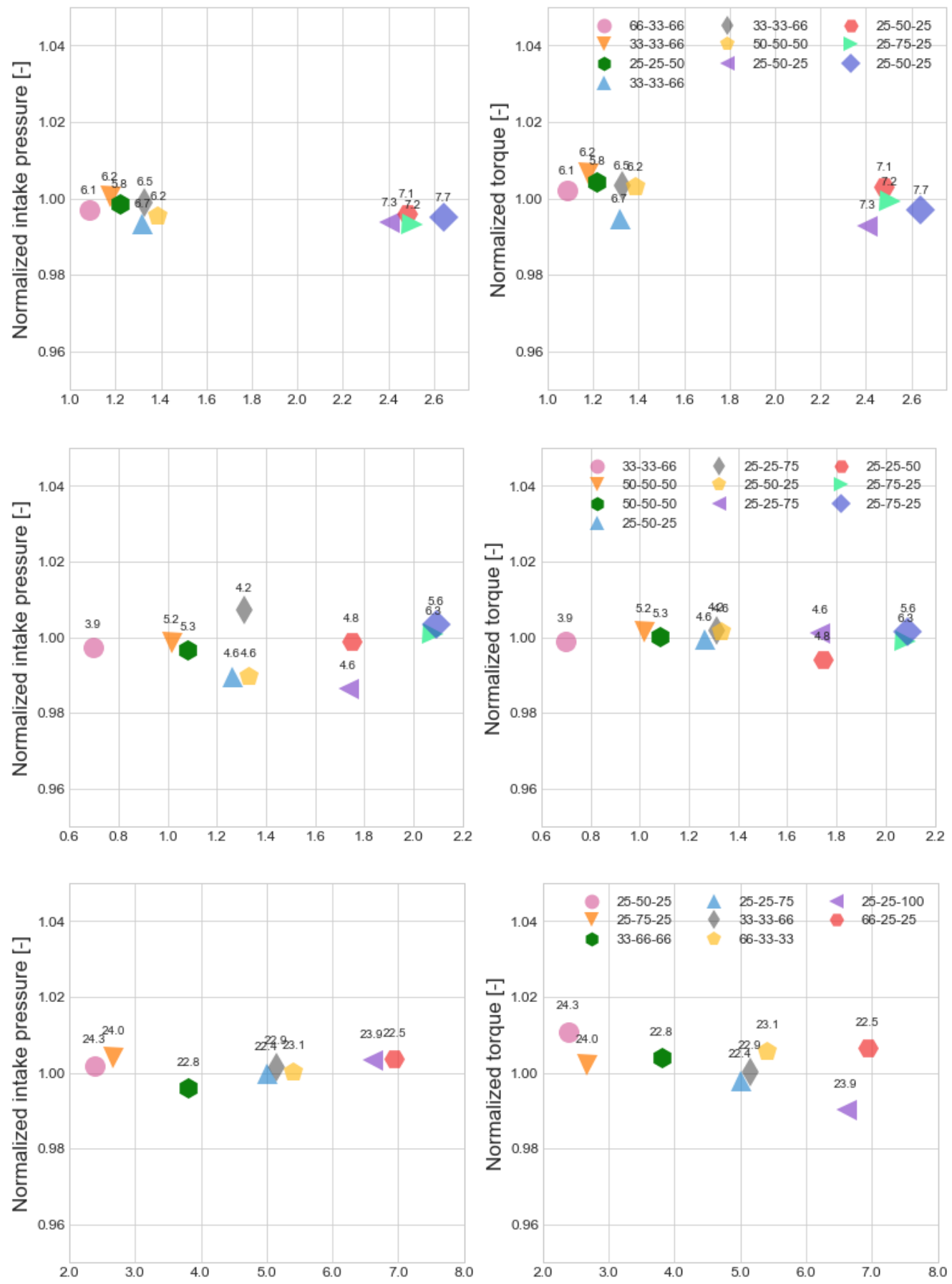

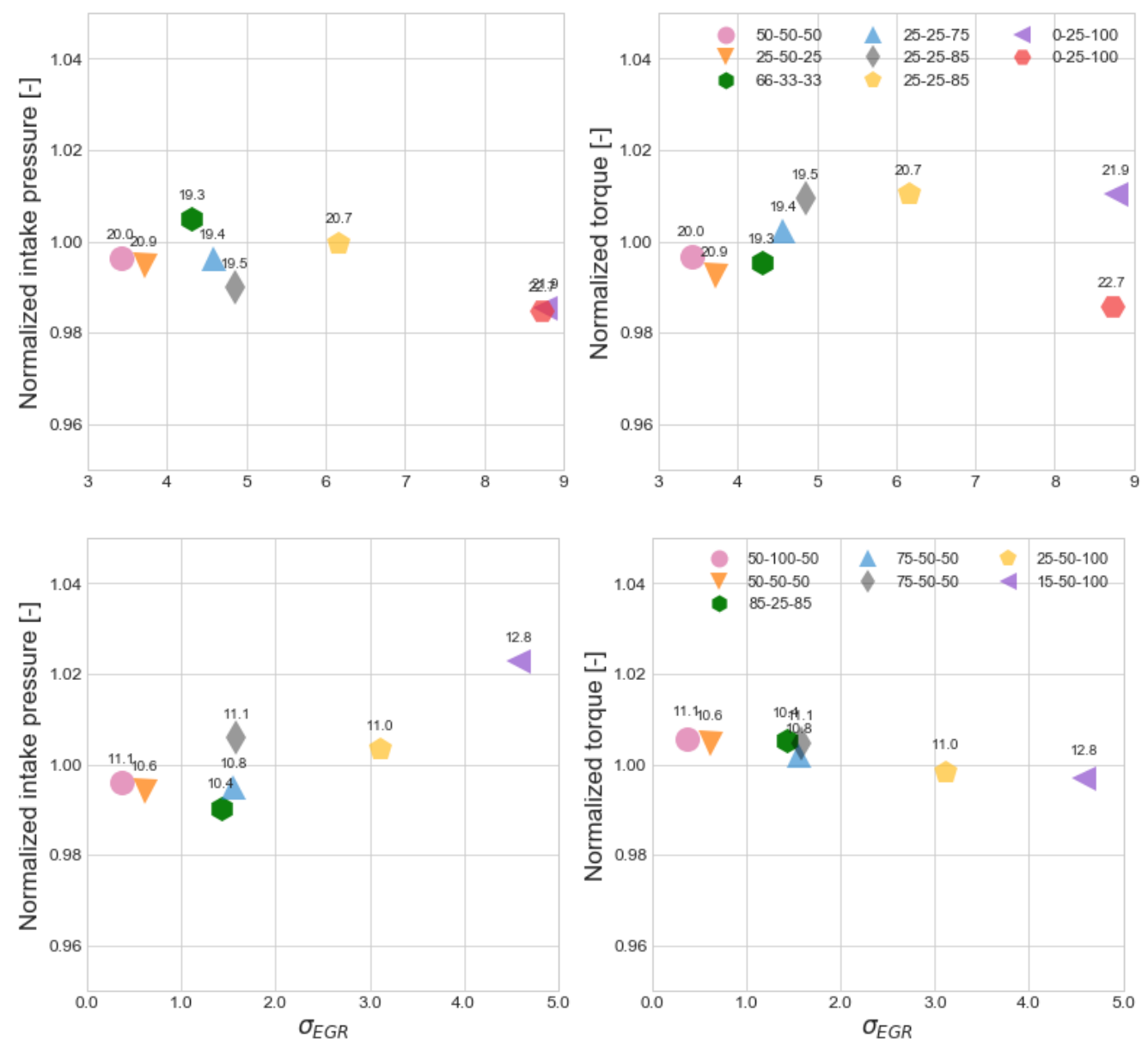

Figure 4.6. Intake manifold pressure (left) and engine torque (right) both of them referenced to the nominal value and vs EGR standard deviation at 1250, 1500, 2000, 2500 and $3000 \mathrm{rpm}$ engine conditions (from top to bottom).

Figure 4.7 presents the NOx values related to the average value for each engine running condition, measured in the exhaust manifold to take the information per cylinder (numbered from 1 to 4 ) and downstream the turbine to measure the raw NOx emissions value (named T). The five plots rows correspond to the 1250, 1500, 2000, 2500 and $3000 \mathrm{rpm}$ engine running conditions. The $X$-axis represents the EGR rate on the plot on the left, and the EGR standard deviation on the right. The left plot shows the effect of the EGR in the NOx emissions, cylinder to cylinder, and in the exhaust. The plot on the right shows the engine 
raw NOx as a function of the standard deviation of the EGR. The average EGR rate is labelled above the dots.

NOx values were not measured at $1250 \mathrm{rpm}$ because the vibration of the engine at that engine running conditions. It was necessary long time to measure the NOx in each cylinder. The engine could not endure the extreme conditions related to the EGR rate and EGR standard deviation at that speed. So, at 1250 $\mathrm{rpm}$, in the plot of the left, the numerated points corresponding to the cylinders, do not indicate the NOx values per cylinder (it is the raw NOx in all cases) but they are represented to observe the EGR rate for each cylinder and to take a visual idea of the dispersion level. Naturally, this phenomenon is the same for all measurements of exhaust emissions but smoke, due to the smoke emissions need only a few seconds to measure so it was possible to carry out the measurement successfully.

Paying attention, for example, to $3000 \mathrm{rpm}$ working operation point it is possible to observe that the case with the lowest standard deviation (50-100-50) has a very similar EGR rate value in each cylinder. From left to right, in the sense of the flow, the cylinders 1, 2 and 3 have an EGR rate very close to the nominal value, $11 \%$, and cylinder 4 has a little more, close to $12 \%$, what represents an increment of the $9 \%$ approximately referred to the nominal value.

In the 25-50-100 case that presents a middle standard deviation level, the cylinders 1 and 2 have $8 \%$ and $8.5 \%$ EGR rate, the cylinder 3 has $12.5 \%$ and cylinder 4 has $15.5 \%$ of EGR rate. In this case, the minimum and the maximum EGR rate represents a reduction of $27 \%$ and an increment of $41 \%$ respectively.

In the 15-50-100 case, with the highest standard deviation, cylinders 1 and 2 have similar values of EGR rate than the second case (between $8 \%$ and $8.5 \%$ ), cylinder 3 has $16.5 \%$ and cylinder 4 close to $18.5 \%$ EGR rate. Cylinder 4 shows the most dramatic increase of the EGR rate, cylinder 4 presents an increment of $68 \%$ referred to the nominal value $(11 \%)$. Moreover, particularly in this case with the highest standard deviation, the average EGR rate is slightly higher than nominal value, $12.8 \%$ instead $11 \%$. Even with this increase in the average EGR rate, $12.8 \%$, the increment in cylinder 4 is $44 \%$ higher, which is the highest difference in any case at $3000 \mathrm{rpm}$. It is possible to observe that a higher standard deviation means a large difference in terms of EGR rate between 
cylinders. In this case, the difference between the lowest and the highest EGR rate per cylinder is close to 10 points, from $8 \%$ on cylinder 1 to slightly more than $18 \%$ on cylinder 4 .

Although each cylinder and each case presents different values of EGR rate and standard deviation respectively, all the cases were performed at constant NOx level for the same working operation point. In some cases, it was necessary to increase the EGR rate, to keep the same NOx value. An example was commented before, where the last case at $3000 \mathrm{rpm}$ (15-50-100) reveals an average EGR rate of $12.8 \%$ instead of $11 \%$. While the cases with less EGR standard deviation presented a similar value to the nominal setup.

This effect is observed too at 1250, 1500 and $2500 \mathrm{rpm}$ running conditions, although in this last one the effect is milder. However, this effect it is not observed at the $2000 \mathrm{rpm}$ working operation point. The 3000, 1250 and $1500 \mathrm{rpm}$ working operation points have in common a low average of EGR rate (lower than $23 \%$ and $20 \%$ presented by 2000 and $2500 \mathrm{rpm}$ operation points respectively). For all cases, a $6 \%$ difference in NOx level is accepted when controlling the EGR valve at the engine operating condition between the different dispersion valves configurations.
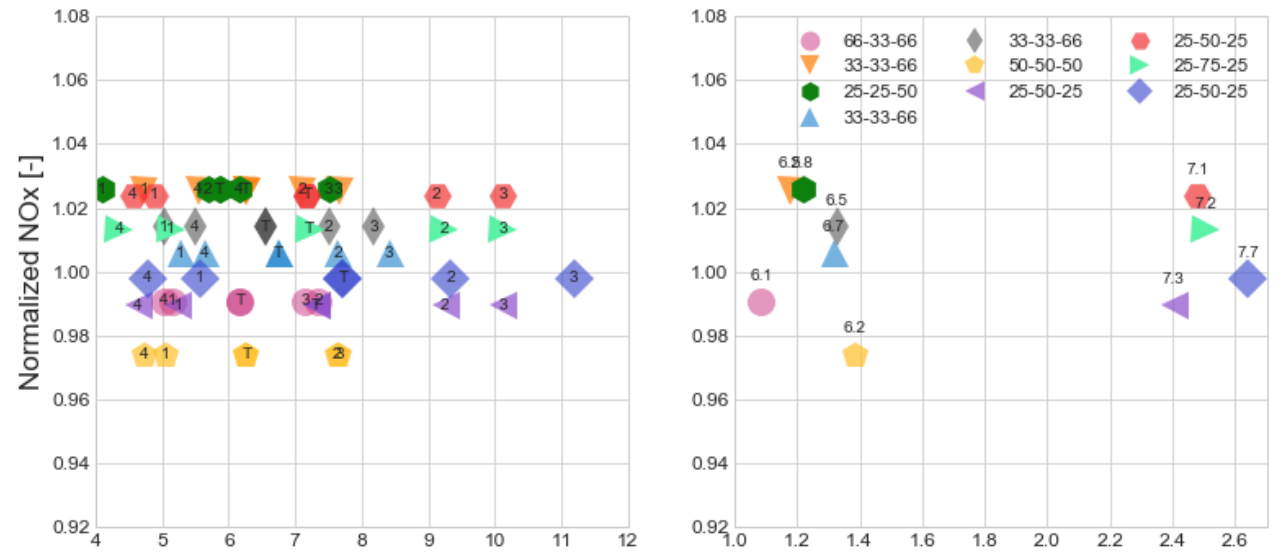

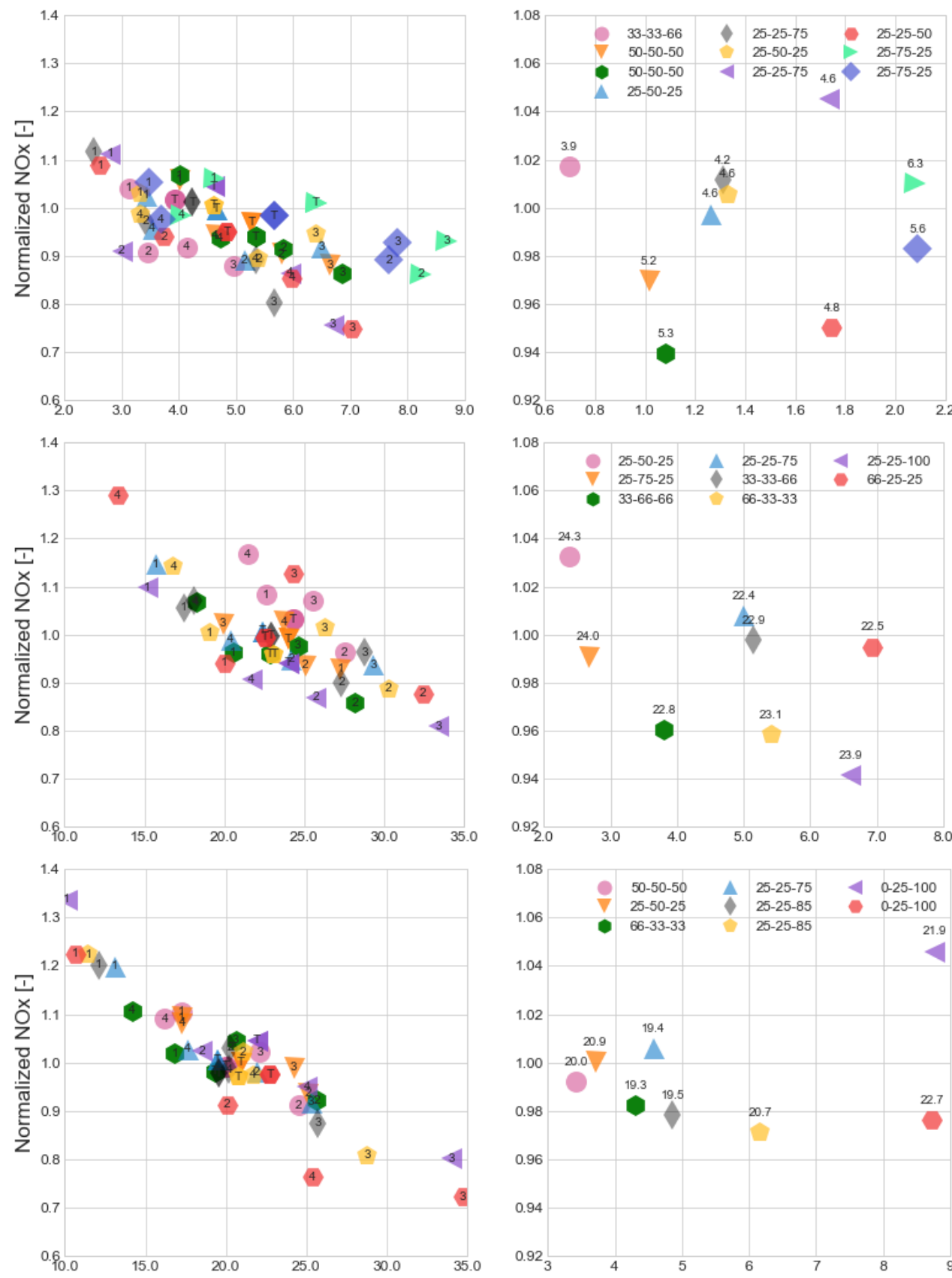

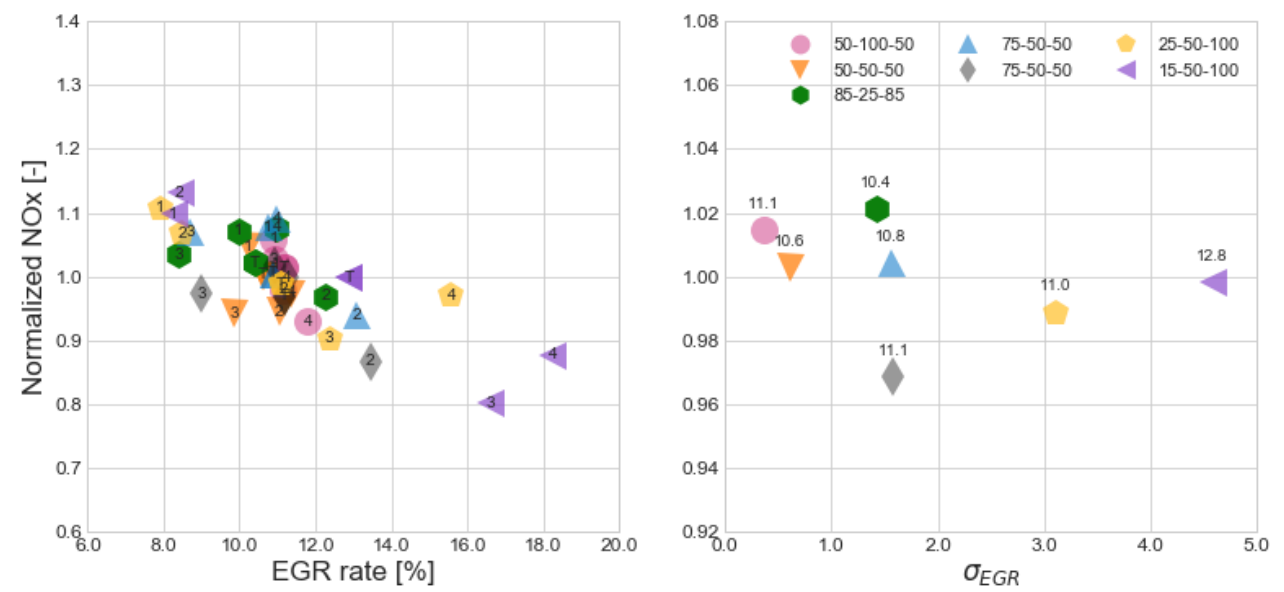

Figure 4.7. Cylinder and engine NOx values vs. EGR rate (left), and engine raw NOx vs. EGR standard deviation (right) for the 1250, 1500, 2000, 2500 and 3000 rpm operation points (from top to bottom).

\subsubsection{Influence on opacity of exhaust gases}

Figure 4.8 shows the opacity vs EGR standard deviation. The order, from left to right firstly and from top to bottom secondly, is 1250, 1500, 2000, 2500 and 3000 rpm running operation points.

Paying attention to $1250 \mathrm{rpm}$ it is possible to observe that the 25-25-50 dispersion level case presents an anomalous value with very high opacity level, around $85 \%$. For the rest of cases, it is possible to observe that the lower EGR standard deviation points, between 1 and 1.4, show lower opacity values, around $17 \%$ on average, than the higher EGR standard deviation points, between 2.4 and 2.7, that show higher opacity values, around $27 \%$ on average, what means an increment of $37 \%$.

At $1500 \mathrm{rpm}$ it is observed a strange phenomenon, two points with the highest EGR standard deviation, 2.1, present lower opacity values, 5 and $8 \%$ respectively, than the three just before, around 20, 23 and 33\%; and similar to the first five cases with EGR standard deviation values between 0.7 and 1.3, and opacity values between 6 and 9\%. Paying attention to the normalized NOx values in Figure 4.7, the two highest EGR standard deviation points (25-75-25) present low differences of normalized NOx among cylinders (from 1.05 to 0.85 approximately). While the three points with the highest opacity values and less 
EGR standard deviation level (25-25-50 and two 25-25-75) present higher differences of normalized NOx among cylinders (from 1.1 to 0.73 approximately) than the two highest standard deviation cases. This information is contradictory due to a higher NOx emissions dispersion among cylinders is expected according to higher EGR dispersion. This singular effect is tried to explain in next Figures 4.9 and 4.10 .

2000 and $2500 \mathrm{rpm}$ do not present particularities in the results. The opacity levels increase when the EGR standard deviation increase too. At $2000 \mathrm{rpm}$ the opacity increases from $29 \%$ to $51 \%$, what means an increment of $76 \%$. Moreover, at $2500 \mathrm{rpm}$ the opacity increases drastically, from $12 \%$ to $90 \%$, what means an increment of $650 \%$. However, $2500 \mathrm{rpm}$ working operation point presents the highest variation of EGR rate, shown just before in Figure 4.7, and EGR standard deviation, from $11 \%$ to $35 \%$ (higher than the lowest opacity point, which shows variations from $16 \%$ to $25 \%$ ) and from 3.4 to 8.8 respectively. This huge variation of the EGR rate and the EGR standard deviation explains the huge increment of opacity values.

Finally, at $3000 \mathrm{rpm}$ running conditions, the trend is the same than before, if the EGR standard deviation increases, the opacity increases too. Moreover, the EGR rate must be increased with the EGR standard deviation to keep the NOx constant. In this case, the EGR standard deviation variates from 0.3 to 4.6 and the opacity increases from $18 \%$ to $49 \%$, what means an increment of $172 \%$.
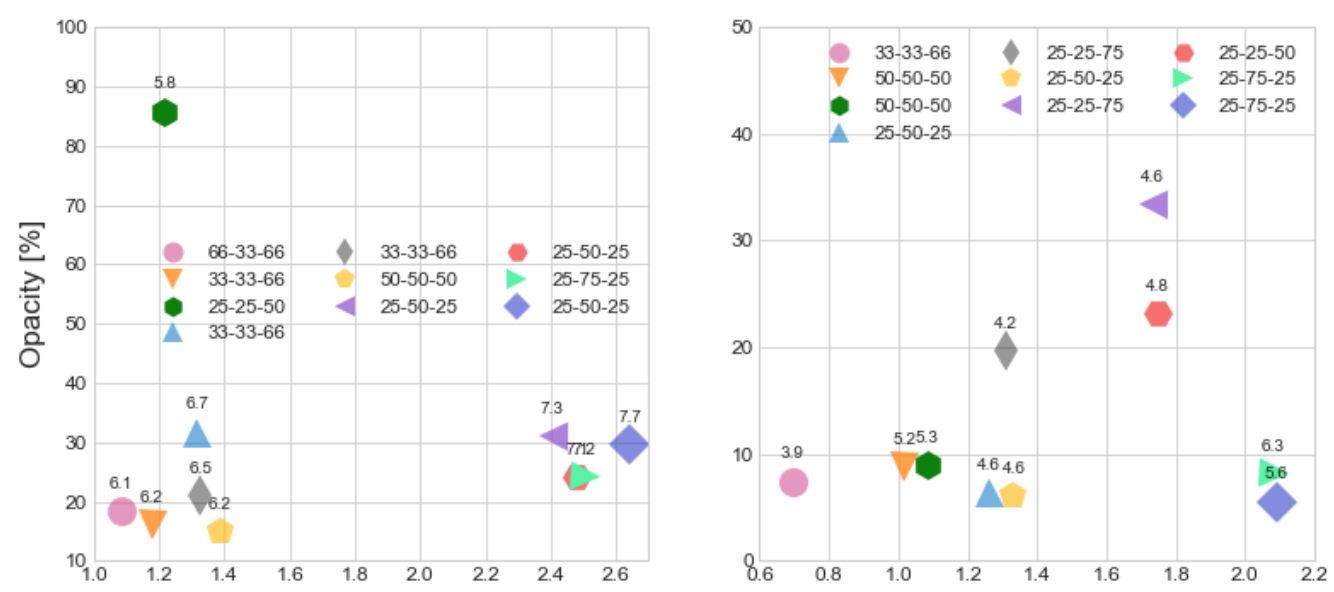

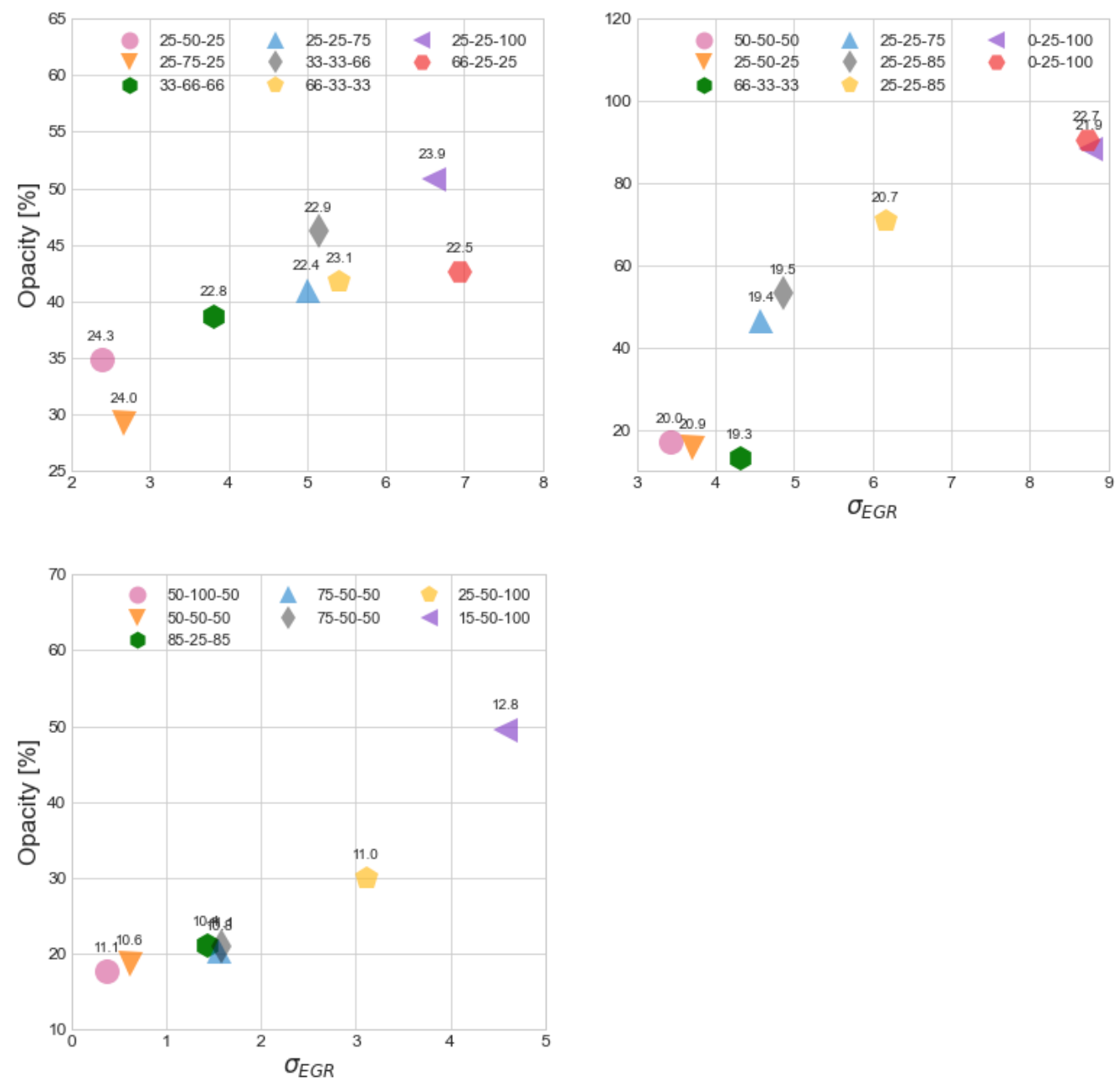

Figure 4.8. Opacity vs. EGR standard deviation for the 1250, 1500, 2000, 2500 and $3000 \mathrm{rpm}$ operation points (from left to right and from top to bottom).

In Figure 4.9, it is possible to observe the intake $\mathrm{CO}_{2}$ pipe to pipe in percentage for all EGR dispersion levels at $1500 \mathrm{rpm}$. It must be remembered that the three cases with highest opacity levels presented the highest differences between NOx among cylinders. It is possible to see how the three cases with highest opacity level presented in Figure 4.8 showed higher $\mathrm{CO}_{2}$ differences between pipes of the same cylinder too in Figure 4.9, especially in cylinders 1, 3 and 4. It is possible to see a similar situation, but softer, in the lowest EGR standard deviation and EGR rate case. 
However, this case offers low opacity levels in comparison, according to the lowest EGR standard deviation and EGR rate values. In addition, these $\mathrm{CO}_{2}$ differences are less pronounced than in the three cases with the highest opacity values. Finally, the two engine running conditions with highest EGR standard deviation show $\mathrm{CO}_{2}$ differences between pipes similar to the low opacity cases.
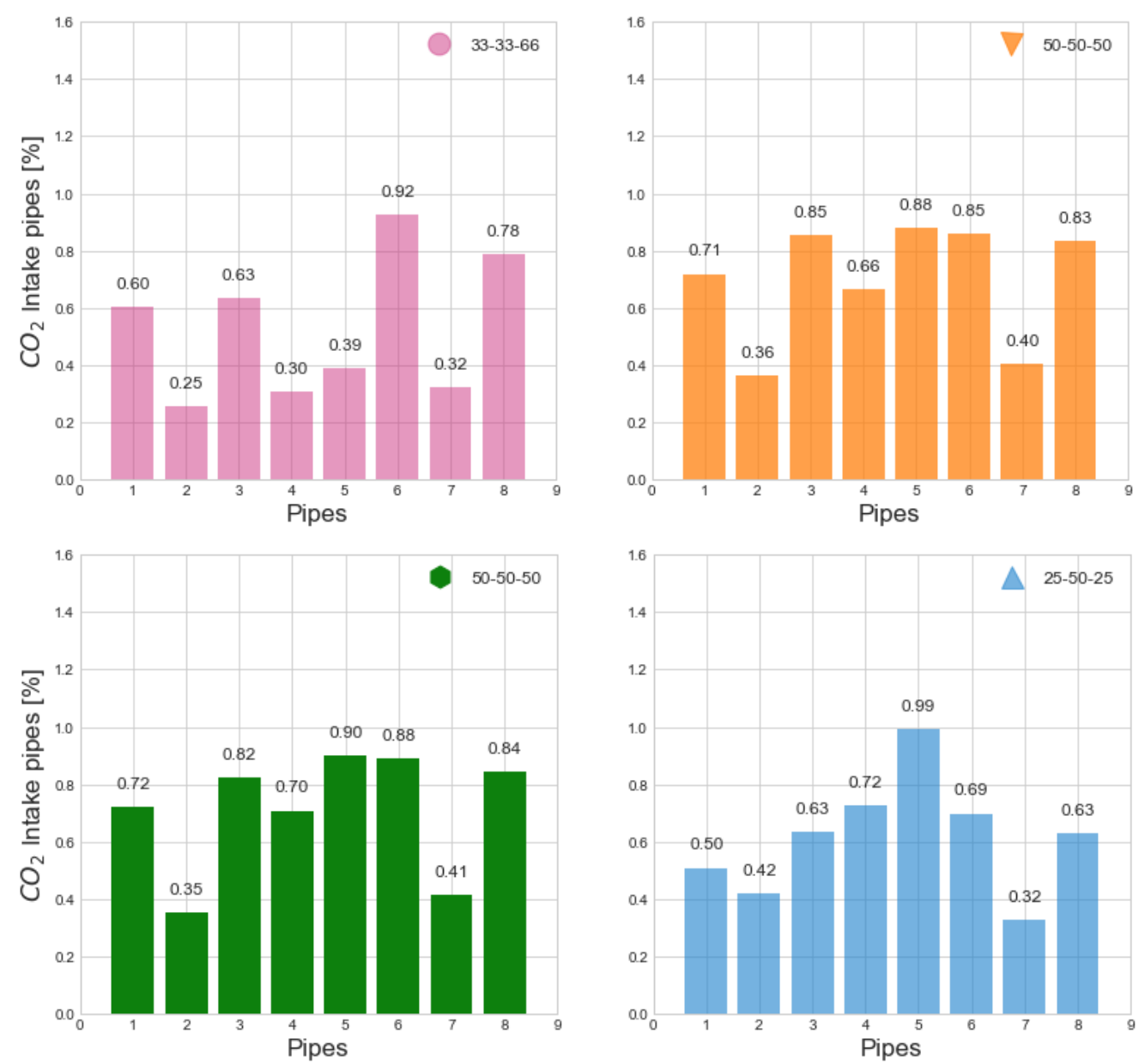

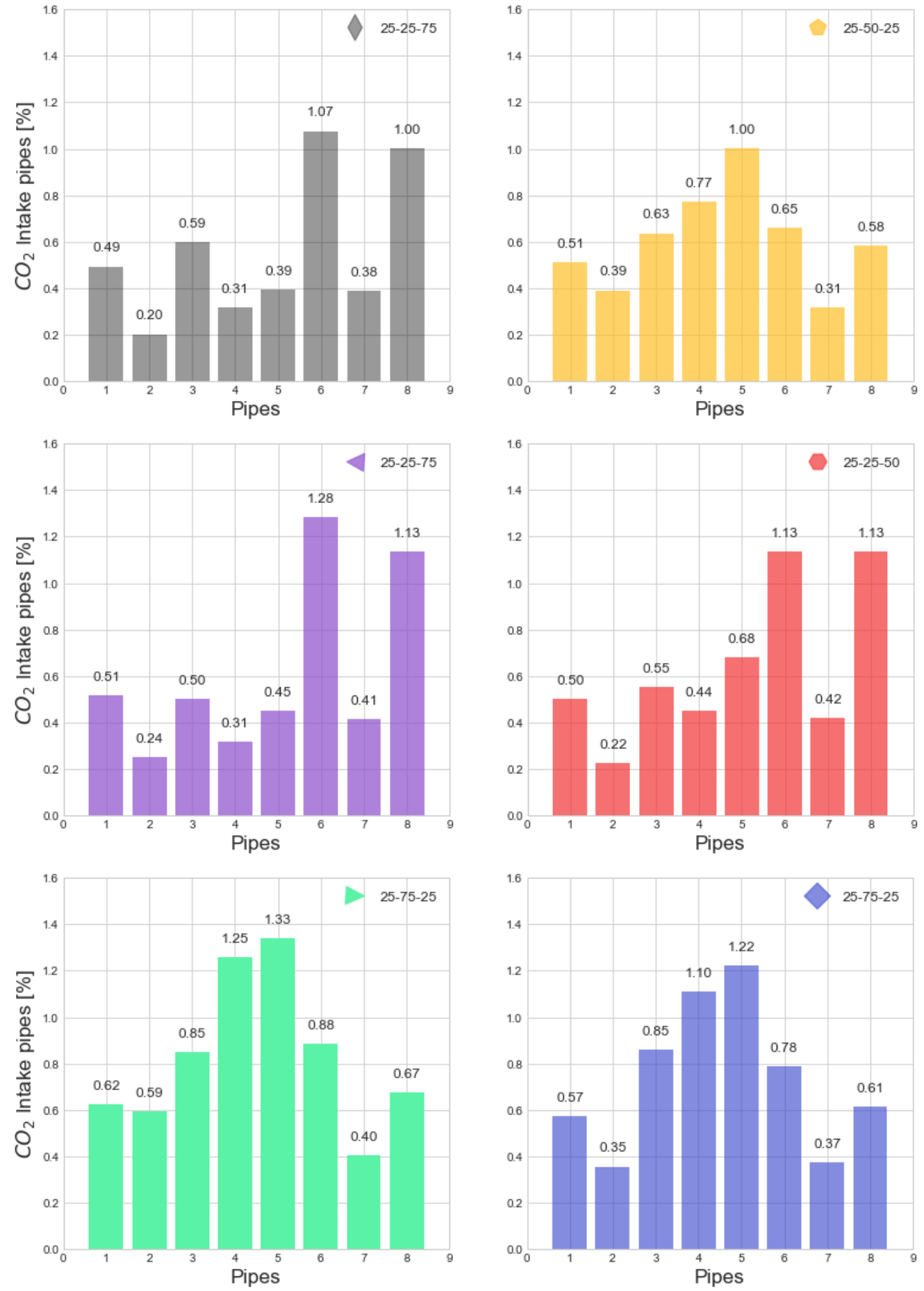

Figure 4.9. $\mathrm{CO}_{2}$ Intake pipes values vs. pipes at $1500 \mathrm{rpm}$ working operation point for each EGR dispersion level. 
Figure 4.10 shows the increment of $\mathrm{CO}_{2}$ between pipes, in percentage, for each cylinder at $1500 \mathrm{rpm}$ working operation point and for each EGR dispersion level. The 25-25-75 case with 1.3 EGR standard deviation level (grey diamond) shown in Figure 4.8, offers a $\mathrm{CO}_{2}$ concentration in cylinder 3 of $0.39 \%$ to pipe 5 and $1.07 \%$ to pipe 6 , as it is indicated in Figure 4.9 , which means an increment of $173 \%$. The $25-25-75$ case with 1.75 EGR standard deviation level (purple triangle) presents differences between $0.45 \%$ (pipe 5) and $1.28 \%$ (pipe 6) of $\mathrm{CO}_{2}$ concentration in cylinder 3, as it is exposed in Figure 4.9 too, what implicates an increment of $185 \%$. Finally, the $25-25-50$ red hexagon case shows differences between $0.42 \%$ (pipe 7 ) and $1.13 \%$ (pipe 8 ) of $\mathrm{CO}_{2}$ concentration in cylinder 4 , as it is presented in Figure 4.9 also, which means an increment of $170 \%$. The rest of cases present differences of $143 \%$ between pipes of the same cylinder as much. In some cases even less, around $100 \%$ or less in all cylinders. Except the lowest EGR standard deviation case commented before, but as it is explained, although the differences between pipes are high, they are not too much high and it is the lowest EGR standard deviation and EGR rate case. Otherwise, the two cases with highest EGR standard deviation and low opacity level (compared to the previous three) offer differences between pipes of the same cylinder lower than $70 \%$ in all cylinders.

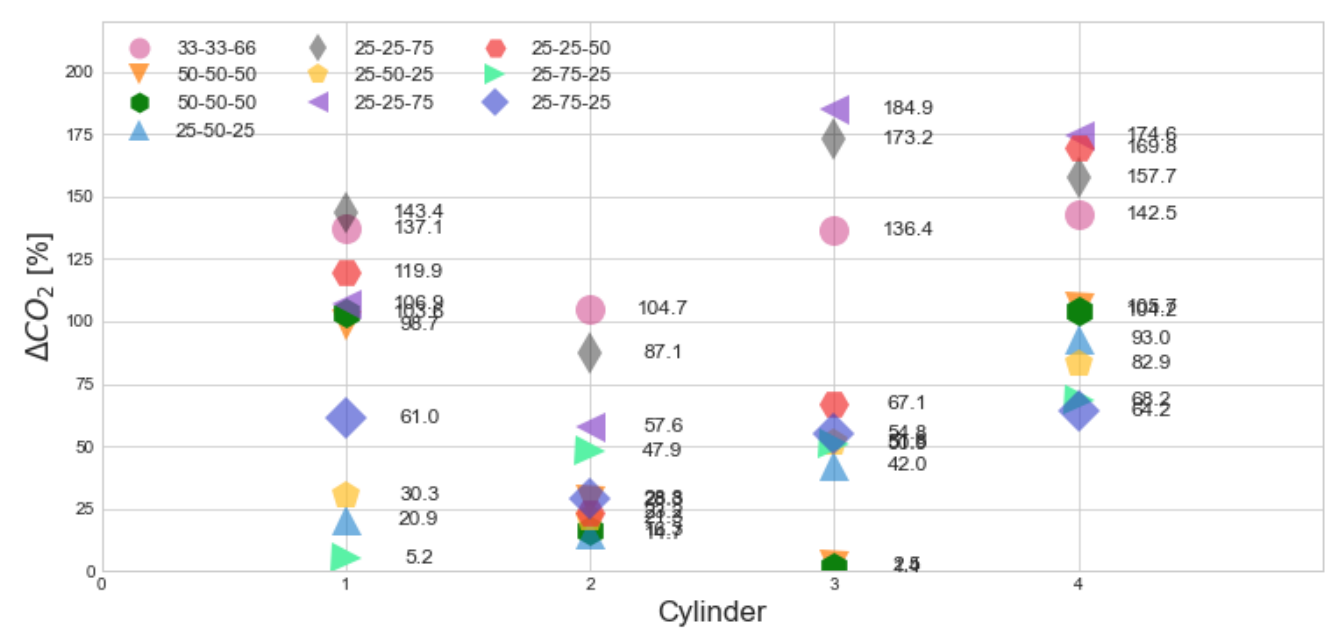

Figure 4.10. Increment of $\mathrm{CO}_{2}$ between pipes vs cylinder at $1500 \mathrm{rpm}$ working operation point for each EGR dispersion level. 
On the other hand, the $1500 \mathrm{rpm}$ engine running conditions show very low EGR rate, around 5\%, which might have two consequences. First, it could compromise the homogeneity of the sample taken by Horiba MEXA 7170DEGR due to the bad mixture between the air and HP EGR flow. The bad mixture could originate different streamlines along the runners and, depending on the position of the probe regarding to the flow, the measurement device could take a richer or leaner sample of EGR rate than the real proportion. This bad mixture effect is more probable with low EGR rates, like this case, due to the lower jet penetration of the EGR flow and the low turbulence and vortex effect generated by this as J. Williams et al. exposed in 2003 [120]. In this way, the EGR dispersion of the cases could be altered. In addition, due to the high dispersion between pipes in some cases, the EGR rate in some runners is extremely low, so the possibility to take badly the sample even increases in this pipes. The second consequence of the low EGR rate is that the range of the EGR dispersion level is marked by the EGR standard deviation defined in Chapter 3. This range is small because it depends directly from the EGR rate that in this case is very low. Moreover, the two cases with highest EGR standard deviation present higher EGR rates, which implies a high proportionally difference compared with other engine running conditions. It moves that cases to higher EGR dispersion levels too because the EGR standard deviation is not a dimensionless parameter.

These two joined consequences, the bad sample possibility and the small EGR standard deviation range with proportionally different EGR rates, could generate an alteration in the position of the cases regarding to the $\mathrm{X}$-axis. Hence, cases with real higher EGR dispersion levels could be shown like cases with lower EGR dispersion levels and vice versa. In that case, it could be possible that the cases with the highest opacity were cases with the highest EGR dispersion actually. In fact, that could explain why at 1500 the three cases with highest opacity values present the highest NOx emissions differences among cylinders as a consequence of a real higher EGR dispersion among cylinders that could be not reflected. In that way these results must be taken into account with carefulness.

Other interesting effect is perceived in Figure 4.7 observed in all cases at 3000 rpm engine running conditions, excepting 50-100-50 pink circle case. Cylinder 3 presents lower EGR rate than 4 but its NOx are lower too. This information is 
contradictory due to the EGR is a strategy to reduce the NOx emissions precisely, and higher EGR rates are related to lower NOx emissions as it is explained in Chapter 2. Similar effect happens between cylinder 1 and 3 in four cases: 50-50-50, 85-25-85 and both (blue triangle and grey diamond) 75-50-50, where cylinder 3 shows lower EGR rate than cylinder 1, but lower NOx level too. Finally, the 50-50-50 orange triangle case offers the same situation between cylinder 2 and cylinder 4, where cylinder 2 presents lower EGR rate and lower NOx emissions than cylinder 4 . Nevertheless, the effect is especially noticeable to 15-50-100 purple triangle case, 25-50-100 yellow pentagon case and 85-25-85 green hexagon case, where the NOx are around 10\% less in cylinder 3 and it presents 2 or 3 points less of the EGR rate. On the other hand, the effect is less perceptible in both 75-50-50 cases (blue triangle and grey diamond) between cylinders 3 and, 1 or 4, and 50-50-50 orange triangle between cylinder 2 and 4 . The NOx and EGR rate differences between cylinder 3 and 4 in 50-50-50 orange triangle case is not very clear but more than the last mentioned.

The information shown in Figure 4.11 that shows the intake $\mathrm{CO}_{2}$ pipe to pipe in percentage for all EGR dispersion level cases at $3000 \mathrm{rpm}$ could explain this behavior. Paying attention to Figure 4.11 it is possible to observe that all cases, except 50-100-50 pink circle case, present higher difference of $\mathrm{CO}_{2}$ concentration between the pipes of cylinder 3 than the pipes of cylinder 4 . Furthermore, in the four cases where the cylinders 1 and 3 reveal a similar effect, it is possible to find the same situation than before again, the difference in $\mathrm{CO}_{2}$ concentration between pipes of cylinder 3 are higher than between pipes of cylinder 1 . With the exception of the 75-50-50 blue triangle case, which the difference of the $\mathrm{CO}_{2}$ between pipes is very similar between the two cylinders, even slightly higher in cylinder 1. However, as it was commented in the last paragraph, the difference of NOx and EGR rate between cylinders in that case and in the other (grey diamond) 75-50-50 is less perceptible, so small variations in other parameters could justify the effect.

Finally, cylinder 2 presents higher $\mathrm{CO}_{2}$ difference between pipes than cylinder 4 in 50-50-50 case. In addition, not only for that case, this cylinder shows very high differences between pipes for other three cases: 85-25-85 green hexagon and both 75-50-50 (grey diamond and blue triangle). However, the EGR rate of the cylinder 2 in these three cases is higher than cylinder 4 , so the NOx 
emissions are lower for cylinder 2 but it is not possible to observe the effect of the EGR dispersion between pipes in that way.
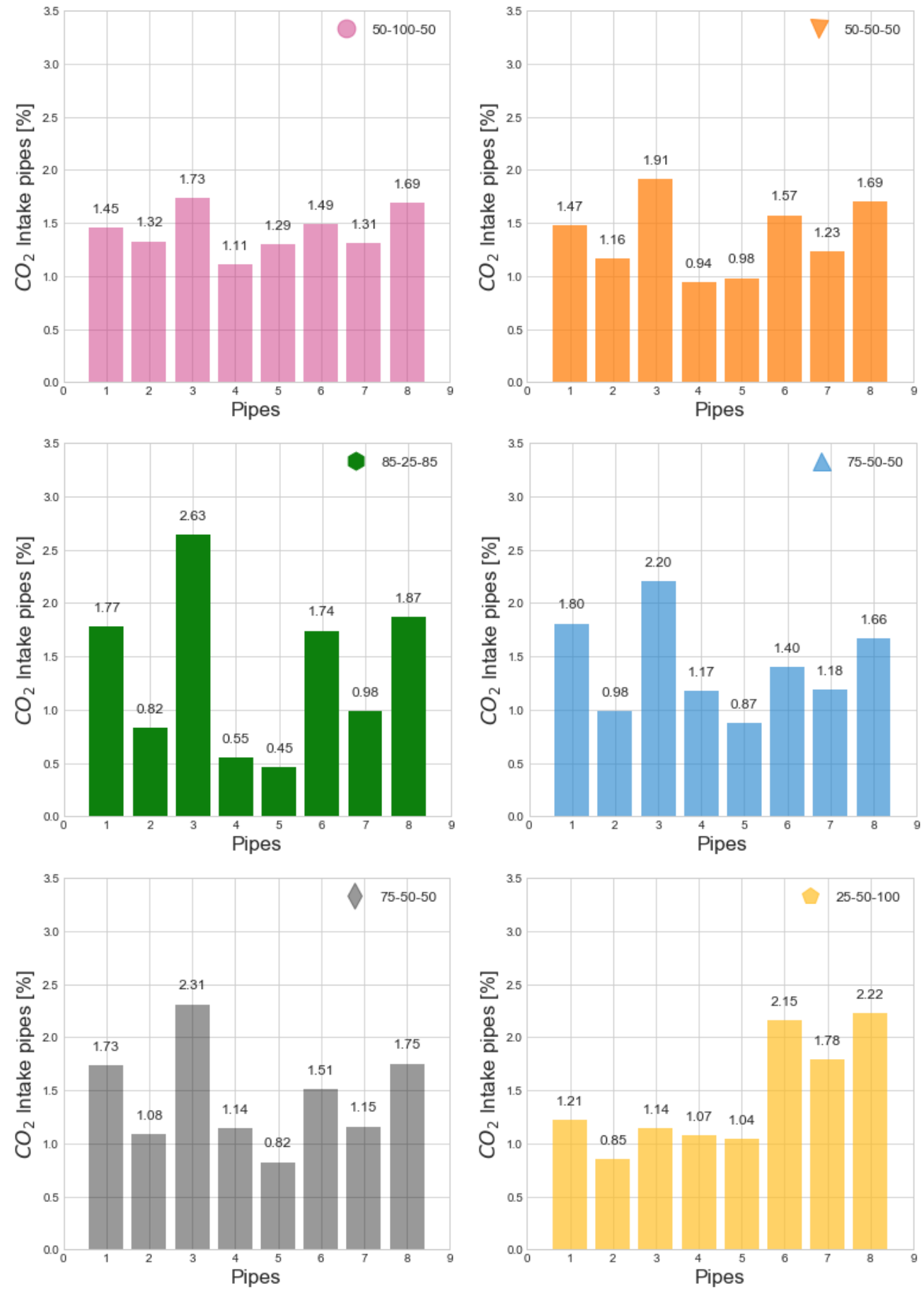


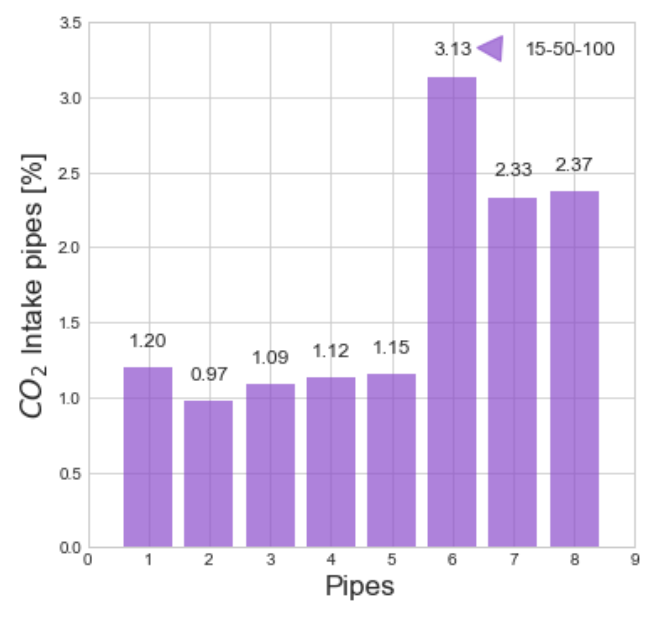

Figure 4.11. $\mathrm{CO}_{2}$ Intake pipes values vs. pipes at $3000 \mathrm{rpm}$ working operation point for each EGR dispersion level.

Figure 4.12 shows the increment of $\mathrm{CO}_{2}$ between pipes, in percentage, for each cylinder at $3000 \mathrm{rpm}$ working operation point and for each EGR dispersion level. In the lowest EGR standard deviation case, 50-100-50, where this phenomenon is not observed, the difference in $\mathrm{CO}_{2}$ concentration between pipes in cylinder $4,1.31 \%$ in pipe 7 and $1.69 \%$ in pipe 8 as it is presented in Figure 4.11 , is higher than in cylinder $3,1.29 \%$ in pipe 5 and $1.49 \%$ in pipe 6 . So, in this case, the $\mathrm{CO}_{2}$ concentration difference between pipes in cylinder 3 is $15 \%$ and in cylinder 4 is $29 \%$.

The phenomenon is the opposite in the rest of cases. In 50-50-50 orange triangle case, cylinder 3 shows higher difference $\mathrm{CO}_{2}$ concentration between pipes than cylinders 1 and 4 . The $\mathrm{CO}_{2}$ concentration in the pipes of cylinder 3 is $0.98 \%$ and $1.57 \%$ for pipes 5 and 6 respectively. The $\mathrm{CO}_{2}$ concentration in cylinder 1 is $1.47 \%$ in pipe 1 and $1.16 \%$ in pipe 2 and for cylinder 4 the $\mathrm{CO}_{2}$ concentration is $1.23 \%$ in pipe 7 and $1.69 \%$ in pipe 8 , as it is indicated in Figure 4.11 . Therefore, the difference between pipes in cylinder 3 is $60 \%$, which is higher than the difference in cylinder $4,27 \%$, and in cylinder $1,37 \%$, as it is possible to consult in Figure 4.12. As it was commented before, it is possible to see how the cylinder 2 presents a high difference between pipes too, 103\%, that it is higher than cylinder $4,27 \%$ and, although the EGR rate of the cylinder 2 is lower than the cylinder 4 , it offers a lower NOx emissions level too. 
In 85-25-85 green hexagon case, the $\mathrm{CO}_{2}$ concentration in pipes 5 and 6 is $0.45 \%$ and $1.74 \%$ respectively, whilst the $\mathrm{CO}_{2}$ concentration in cylinder 4 is $0.98 \%$ and $1.87 \%$ for pipes 7 and 8 respectively and, and the $\mathrm{CO}_{2}$ concentration in cylinder 1 is $1.77 \%$ in pipe 1 and $0.82 \%$ in pipe 2, as it is showed in Figure 4.11. Figure 4.12 presents that the difference between pipes in cylinder 3 is $279 \%$, which is higher than the difference between pipes in cylinder 4,90\%, and in cylinder 1 , $116 \%$. This is one of the more noticeable cases where the cylinder with lower EGR rate but higher EGR dispersion between pipes shows lower NOx emissions. In this case, it is possible to see how the cylinder 2 presents a very high difference between cylinders too, 378\%, but the EGR rate is higher than the others, consequently it offers the lowest NOx emissions level but it is not possible observe the effect of the EGR dispersion between pipes in this way.

In 75-50-50 triangle blue case, the $\mathrm{CO}_{2}$ in pipes 5 and 6 is 0.87 and $1.4 \%$ respectively, while the $\mathrm{CO}_{2}$ concentration in pipes $1,2,7$ and 8 is $1.8 \%, 0.98 \%$, $1.18 \%$ and $1.66 \%$ respectively, as it is exposed in Figure 4.11 . Therefore, Figure 4.12 shows that the difference between pipes in cylinder 3 is $61 \%$, in cylinder 1 is $83 \%$ and in cylinder 4 is $41 \%$. In this case, the difference between pipes is higher in cylinder 3 than in cylinder 4 but lower in cylinder 3 than in cylinder 1. Nevertheless, they are very similar between them than in the other cases, where the $\mathrm{CO}_{2}$ differences among cylinder 3 and cylinders 1 or 4 are higher. Moreover, in this case the difference of NOx between the cylinders is very low compared with the other cases too. Therefore, this is a particular case with very similar values in fact and where the influence of the variables is not very clear. In addition, cylinder 2 presents the highest $\mathrm{CO}_{2}$ difference between pipes in this case, $87 \%$, but it is the cylinder with highest EGR rate too, so consequently the NOx emissions are the lowest and the effect of the EGR dispersion between pipes is not observable.

In 75-50-50 grey diamond case, the $\mathrm{CO}_{2}$ concentration in pipes 5 and 6 is 0.82 and $1.51 \%$ respectively. Whilst the $\mathrm{CO}_{2}$ concentration in pipes 1 and 2 is $1.73 \%$ and $1.08 \%$ and in pipes 7 and 8 is $1.15 \%$ and $1.75 \%$ respectively, as it is presented in Figure 4.11. Hence, the difference between pipes in cylinder 3 is $83.5 \%$, which is higher than the difference in cylinders 1 and 4 where it is $60 \%$ and $51 \%$ respectively as it is possible to notice in Figure 4.12. The effect is similar to previous cases where the cylinder with lower EGR rate presents lower NOx 
emissions and higher EGR dispersion between pipes. Like before, cylinder 2 presents the highest $\mathrm{CO}_{2}$ difference between pipes, $103 \%$, but it is the cylinder with the highest EGR rate, so the NOx are the lowest but it is not possible to know the influence of the EGR dispersion between pipes on NOx emissions.

The $25-50-100$ case presents a $1.04 \%$ and $2.15 \%$ of $\mathrm{CO}_{2}$ concentration in pipes 5 and 6 respectively, as long as it offers $1.78 \%$ and 2.22\% in pipes 7 and 8 respectively, as it is shown in Figure 4.11. Hence, in Figure 4.12 it is possible to observe that the difference between pipes in cylinder 3 is $106 \%$, higher than in cylinder 4 that it is $24 \%$. Like before, although the cylinder 3 EGR rate is lower than cylinder 4, it shows lower NOx emissions too and the EGR dispersion between pipes of the same cylinder effect is present once again.

Finally, in 15-50-100 case, the $\mathrm{CO}_{2}$ concentration in pipes 5 and 6 is $1.15 \%$ and $3.13 \%$ respectively, whilst the $\mathrm{CO}_{2}$ concentration in pipes 7 and 8 is $2.33 \%$ and $2.37 \%$ respectively. Therefore, the difference between pipes in cylinder 3 is $172 \%$, higher than in cylinder 4 that it is $1.8 \%$, as it is showed in Figure 4.12 . Once again, the EGR dispersion between pipes appears in the cylinder that, with lower EGR rate, offers lower NOx emissions too.

After the analysis is important to remark that the cases where cylinders with lower EGR rate present lower NOx emissions compared with other cylinders of the same case is more noticeable are: 15-50-100 purple triangle, 25-50-100 yellow pentagon and 85-25-85 green hexagon. In the rest of cases the differences are less significant. However, this three cases offer the highest $\mathrm{CO}_{2}$ differences between pipes. Moreover, $\mathrm{CO}_{2}$ different in cylinder 3 compared with the other cylinders is especially clear for 25-50-100 yellow pentagon and 15-50-100 purple triangle, which are the cases where the effect of lower NOx with lower EGR rate is especially clear. Secondly, although in the 85-25-85 green hexagon case the $\mathrm{CO}_{2}$ difference between pipes is the highest, the rest of cylinders offer high differences too, therefore the $\mathrm{CO}_{2}$ difference compared among cylinders is proportionally lower. Precisely in this case the effect of lower NOx with lower EGR rate is perceptible but less distinctive. 


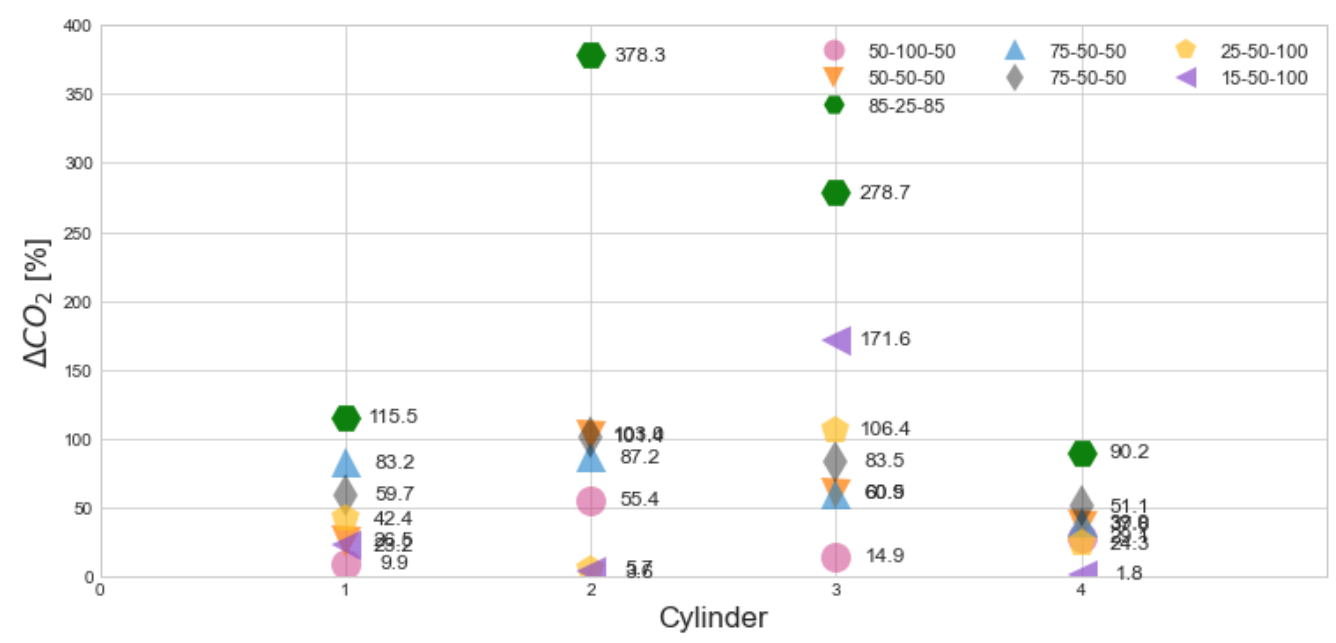

Figure 4.12. Increment of $\mathrm{CO}_{2}$ between pipes vs cylinder at $3000 \mathrm{rpm}$ working operation point for each EGR dispersion level.

Interestingly, at 3000 rpm engine running conditions, when the EGR dispersion between pipes of the same cylinder is higher than others, this cylinder could present lower NOx levels with lower EGR rate. The cause of this interesting effect is unknown. At $1500 \mathrm{rpm}$ engine running conditions this effect is not appreciated because the cylinders of the three cases, where the $\mathrm{CO}_{2}$ differences between pipes appear, are the cylinders with the highest EGR rate. Therefore, they already present the lowest NOx values and it is not possible to know the NOx effect in cases with high EGR dispersion between pipes of the same cylinder.

Furthermore, the high opacity levels effect in cases with high EGR dispersion between pipes at $1500 \mathrm{rpm}$ compared with cases with higher EGR standard deviation but less EGR dispersion between pipes and less opacity is not observed at $3000 \mathrm{rpm}$. In the first place, it could be due to all cases excepting the lowest EGR dispersion level among cylinders (50-100-50 pink circle case) present high $\mathrm{CO}_{2}$ difference between pipes. Moreover the cases with the highest EGR dispersion among cylinders showed the highest $\mathrm{CO}_{2}$ differences between pipes too, excepting 85-25-85 green hexagon case. The 85-25-85 green hexagon case presents the highest $\mathrm{CO}_{2}$ differences between pipes but it does not showed an opacity peak in comparison with the others. As it was commented before, one of the possible reasons is the alteration of the cases order in X-axis. It could 
be a consequence of a bad sampling, due to a bad mixture, along with the small range. All of it owing to the low EGR rate at $1500 \mathrm{rpm}$. Other explanation could be that the $1500 \mathrm{rpm}$ engine running conditions mixes worse the EGR with the intake air (that come from the two runners of the same cylinder in very different proportions) inside the cylinder than $3000 \mathrm{rpm}$ engine running conditions. Lower speed generates lower turbulence to mix the streamlines.

The presented results about the EGR dispersion between pipes of the same cylinder and the opacity and NOx effects are not the main purpose of this research, $i$. e. the analysis of the HP EGR dispersion among cylinders, not between pipes of the same cylinder. The EGR dispersion between pipes of the same cylinder and its possible effects are beyond the scope of this research. Because of that the results are presented and commented but there were not enough resources and data to extract solid conclusions. Probably, it would be necessary to design specific experimental conditions to reproduce the EGR dispersion between pipes in many cases and maybe the employment of CFD modeling tools too in order to know the combustion process in detail.

\subsubsection{Influence on fuel consumption}

Figure 4.13 presents normalized air mass flow (left) and fuel mass flow (right) both of them vs. EGR standard deviation at 1250, 1500, 2000, 2500 and $3000 \mathrm{rpm}$ engine running conditions from top to bottom. As it was commented before, the 1250 and $1500 \mathrm{rpm}$ engine running conditions do not accept too high EGR rates and EGR dispersion levels due to the critical engine running conditions. Because of that, some parameters do not present significant changes among cases. On the other hand, it is possible to observe how the air mass flow decreases with higher EGR standard deviation significantly at 2000, 2500 and $3000 \mathrm{rpm}$ where the EGR ranges are wider. This phenomenon is explained because to keep the same NOx level it was necessary to increase the EGR rate, as it was commented before. On the right, it is possible to see that the fuel mass flow increases with the EGR standard deviation significantly at 2500 and 3000 rpm. Moreover, the fuel mass flow trend is very similar to the trend observed in the opacity in Figure 4.8 for all cases excepting at 2000 rpm engine running conditions where the opacity values increase according with the increase of the EGR standard deviation, but the normalized fuel mass flow is practically 
constant among cases. This is the lowest load engine running conditions test and the fuel-to-air ratio is low, i. e. it has a lean mixture, and the EGR dispersion effect does not affect significantly to the EGR rate or the fuel consumption. Therefore, the increase in opacity is partially affected by the increment of the fuel consumption too in some cases and not only due to the HP EGR dispersion.

Nevertheless, it is possible to perceive that at $1250 \mathrm{rpm}$ there is a test that presents a very high fuel mass flow consumption. This test is the same that presented an outlier opacity level, around $85 \%$ in Figure 4.8 . Moreover, two of the three cases with particular highest opacity values at $1500 \mathrm{rpm}$ (25-25-75 purple triangle and 25-25-50 red hexagon) present a normalize air mass flow below 1. Besides, at the same time, the three cases (including 25-25-75 grey diamond) offer normalized fuel mass flow above 1, especially the 25-25-75 purple triangle case that is precisely the case with the highest opacity. These joined factors increase the fuel-to-air ratio, which according to the revision of Tree et al. [13] could increment the soot formation. On the other hand the situation for the two cases with highest EGR standard deviation and lower opacity values is the opposite. The 25-75-25 blue diamond case offers a normalized air mass flow above 1 and the 25-75-25 turquoise triangle is around 1 , and both of them present a normalized fuel mass flow below 1 . These factors, in addition to the previously discussed, could explain partially the three particular cases with the highest opacity values at $1500 \mathrm{rpm}$ engine running conditions.

Finally, it is possible to affirm that most of cases are in a margin of $2 \%$, up or down, and all of them are under $5 \%$, so the variations are not very significant and do not explain only by themselves the opacity variations excepting maybe extreme cases like 25-25-50 green hexagon at $1250 \mathrm{rpm}$. 

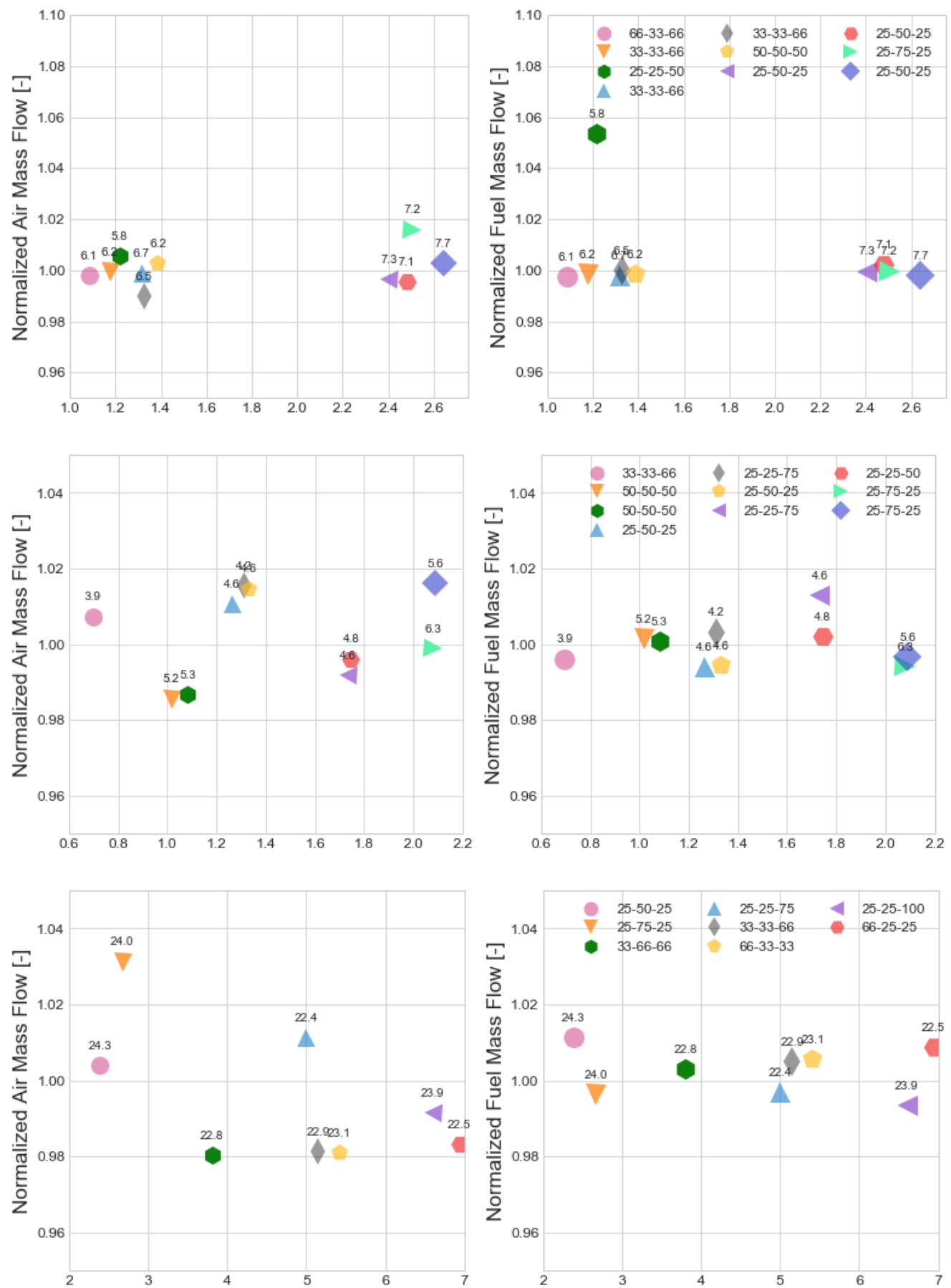

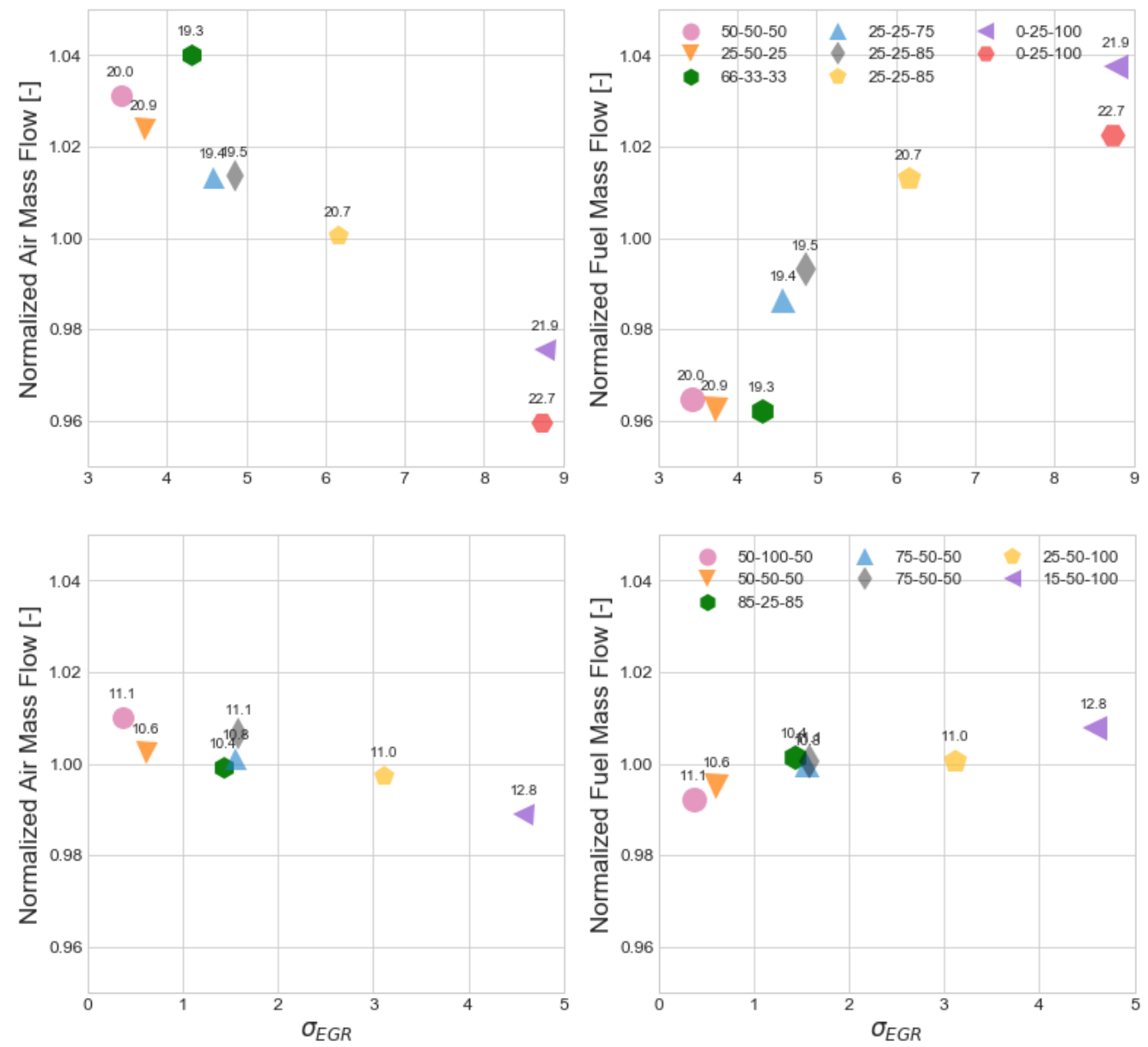

Figure 4.13. Air mass flow vs. EGR standard deviation (left), and fuel mass flow vs. EGR standard deviation (right) for the 1250, 1500, 2000, 2500 and $3000 \mathrm{rpm}$ working operation points (from top to bottom).

Figure 4.14 shows the air-to-fuel ratio measured in the exhaust gases (i. e. lambda) (left) and the normalized Brake Specific Fuel Consumption (BSFC) (right) both of them vs. EGR standard deviation at 1250, 1500, 2000, 2500 and $3000 \mathrm{rpm}$ engine running conditions from top to bottom. Lambda value decreases with the increment of the EGR standard deviation. The effect over BSFC is the opposite, which increases with the increment of the EGR standard deviation. The increment of the BSFC (along with the EGR rate increment in some cases) could explain partially the increment of the opacity [9, 10,11, 12]. This phenomenon is more noticeable in some cases and less in others. Once 
again, the 1250 and $1500 \mathrm{rpm}$ engine running conditions offer small variations of the parameters compared with the others engine running conditions, because of the same reasons commented before.

It is possible to detect, at $1250 \mathrm{rpm}$ engine running conditions, the $25-25-50$ green hexagon case which presents unusual lambda and BSFC values. It is the same test with very high opacity level around $85 \%$. This point shows a very low lambda value, very close to the stoichiometric limit, in fact, and a very high normalized BSFC level too. In this case the differences regarding to the other cases are noticeable and the effect on the opacity is clear.

The results at $1500 \mathrm{rpm}$ correspond with the results showed in Figure 4.13. The two cases with the highest opacity values (25-25-75 purple triangle and 25-2550 red hexagon) that showed before higher normalized fuel mass flow than 1 and lower normalized air mass flow than 1, now present a higher normalized BSFC values than the rest of cases. It would imply an inefficient fuel consumption that could affect to the opacity increase [13].

The invariability for many parameters at $2000 \mathrm{rpm}$ engine running conditions was commented and explained before. Now, in Figure 4.14 the graphical explanation is obtained. The $2000 \mathrm{rpm}$ engine running conditions present the highest lambda value. Therefore, the normalized air mass flow variations observed in Figure 4.13 do not affect significantly to the combustion process and the normalized fuel mass flow and BSFC parameters are not so affected. Hence, the lambda value is not too affected neither. In this way, the evolution of the opacity according to the EGR standard deviation present less similarities with the normalized fuel mass flow and BSFC evolution because they are highly constant parameters in this engine running conditions.

Contrary situation is observed at 2500 and $3000 \mathrm{rpm}$ where the trend is clear in both Figures, 4.13 and 4.14. Both of them present lower normalized air mass flow and higher normalized fuel mass flow according to the increase of the EGR standard deviation. Hence, the lambda value decreases and the normalized BSFC decreases according to the increment of the EGR standard deviation. 2500 and $3000 \mathrm{rpm}$ are higher load engine running conditions than $2000 \mathrm{rpm}$. In addition the lambda value is lower, $i$. e. the mixture is richer. The opacity evolution according to the normalized fuel mass flow and BSFC is more similar 
as a consequence of the enrichment of the mixture that favor the soot creation [13].

In any case, it is possible to affirm that most of normalized values are under $2 \%$ and all of them are under $5 \%$, so the variations are not significant and do not explain only by themselves the opacity variations excepting maybe extreme cases or conditions like 25-25-50 green hexagon case at $1250 \mathrm{rpm}$.
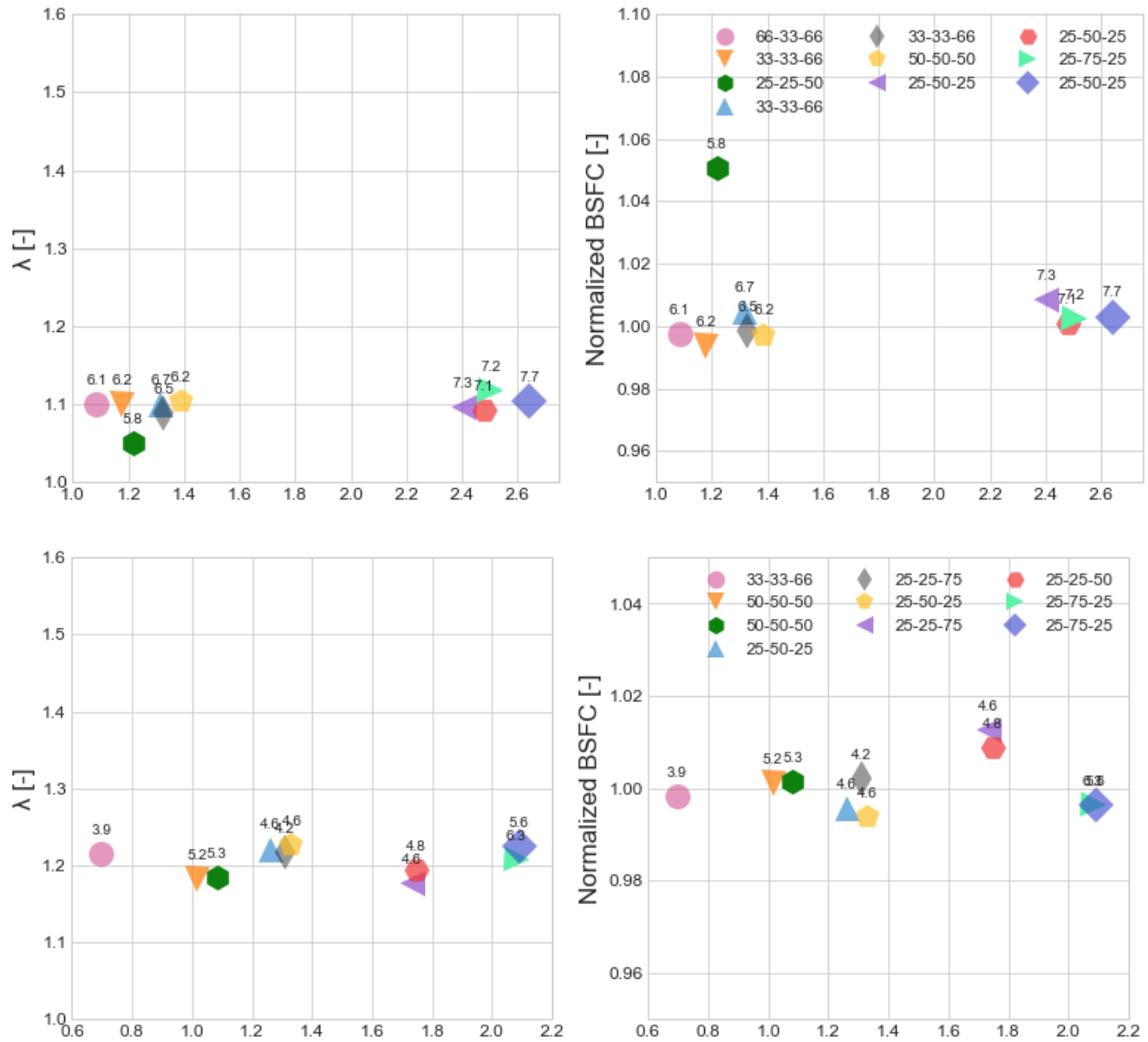

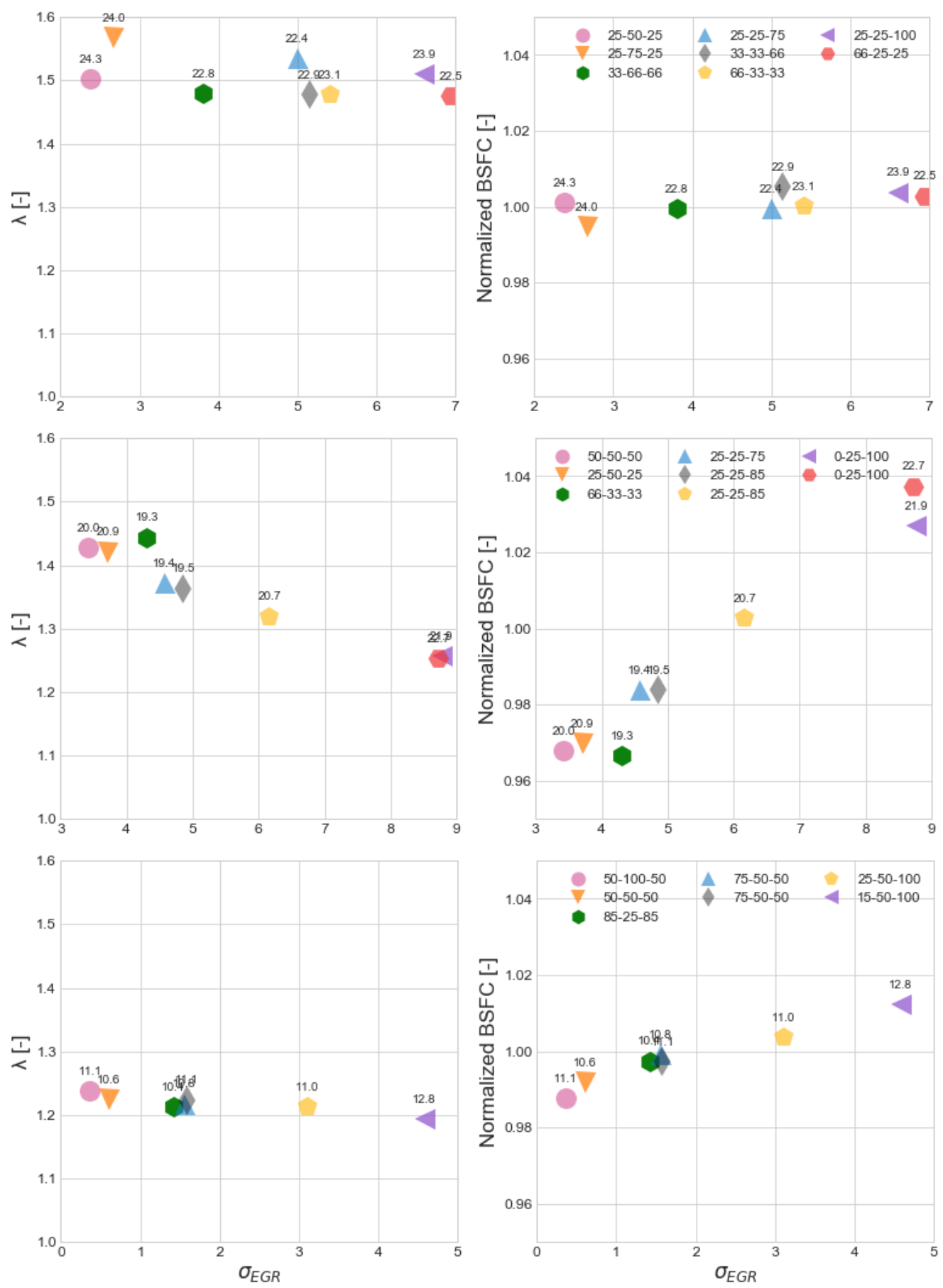

Figure 4.14. Lambda vs. EGR standard deviation (left), and BSFC vs. EGR standard deviation (right) for the 1250, 1500, 2000, 2500 and $3000 \mathrm{rpm}$ working operation points (from top to bottom). 


\subsubsection{Influence on the IMEP}

In order to look up the influence of the EGR dispersion over the in-cylinder pressure traces, Figure 4.15 shows in-cylinder pressure vs cylinder displacement for all the cylinders and different dispersion levels (left). In order to see more clearly the influence, the Indicated Mean Effective Pressure (IMEP), dimensionless with its average for each dispersion level, is represented for all the cylinders versus EGR rate for different dispersion levels (right) at 1250, 1500, 2000, 2500 and $3000 \mathrm{rpm}$ (from top to bottom). Since several consecutive engine cycles were measured in all cylinders, there were only selected 2 or 3 cases for each engine running conditions. The different dispersion levels were taking into account covering the whole spectrum of the EGR dispersion. In this way, the information is presented more clearly.

It is very difficult to derive any conclusion from direct in-cylinder pressure inspection because the $\mathrm{p}-\mathrm{V}$ diagram is practically the same in all cases, excepting a very extreme dispersion level case at $2500 \mathrm{rpm}$ where it is possible to appreciate a different maximum pressure in cylinders 3 and 4 . For the rest of cases, it is not possible to appraise significant differences between case and case and between cylinder and cylinder due to the negligible differences, so the calculations of the IMEP values are provided too.

On the right, Figure 4.15 shows the dimensionless IMEP for all the cylinders (numbering from 1 to 4 ) and the average (named T) as a function of the EGR rate. It is possible to observe that the dispersion affects to the IMEP of the cylinders (individually). Since the tests are performed keeping the engine torque constant, the average of the IMEP among cases is not very altered actually, in any case proportionally to the torque variations showed in Figure 4.6 .

The IMEP variation range, per cylinders, is lower than $5 \%$ most of times with the exception of the very extreme cases at $2500 \mathrm{rpm}$. Therefore, it is possible to affirm that the influence of the EGR dispersion to the IMEP of the cylinders is very limited. 

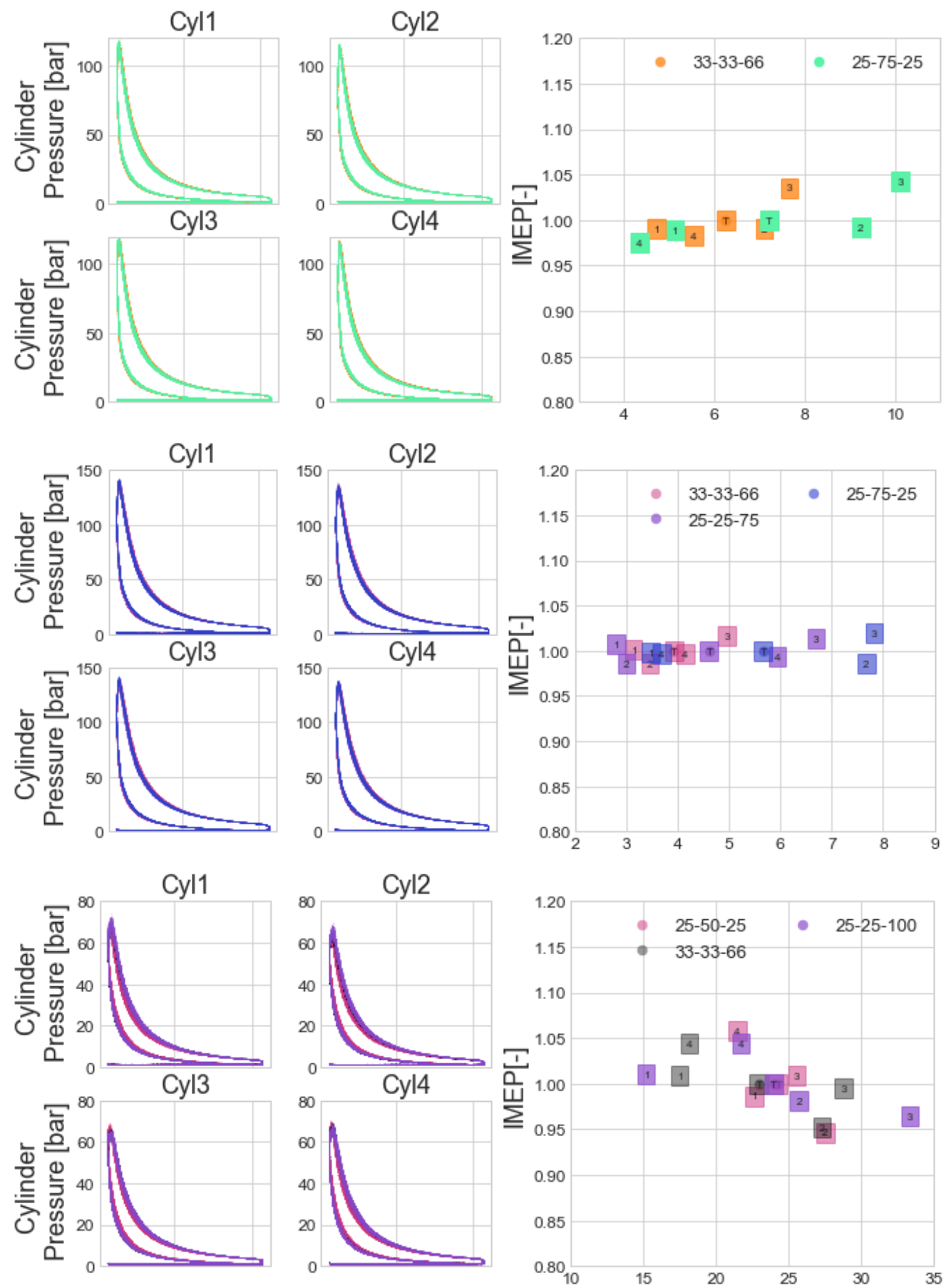

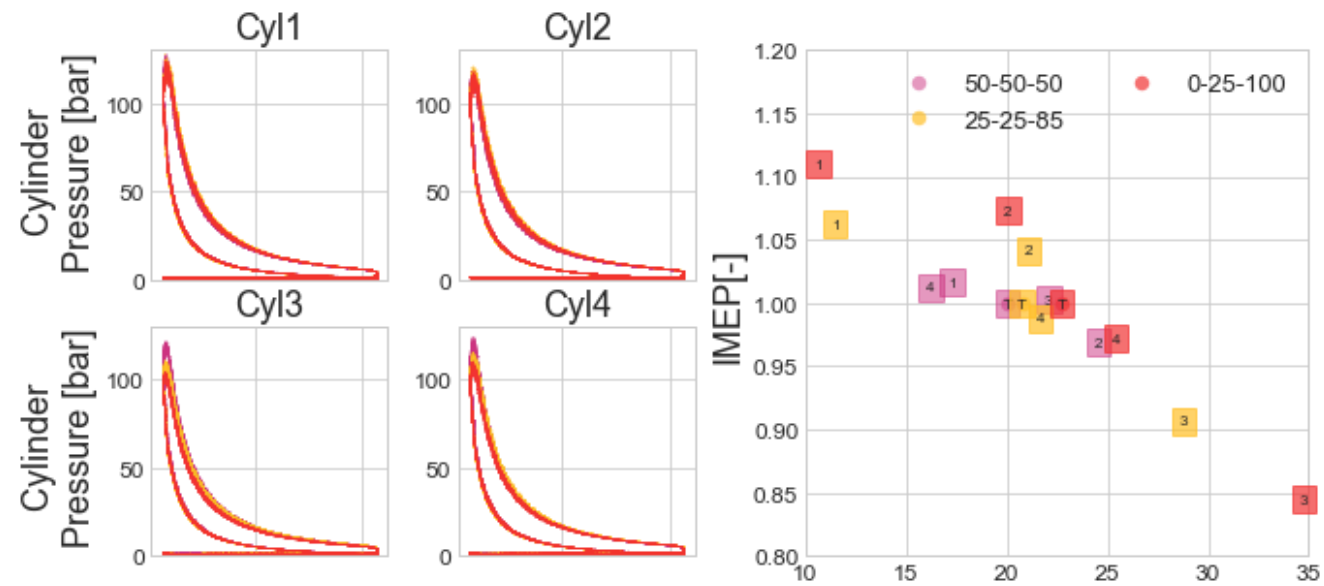

Cyl2
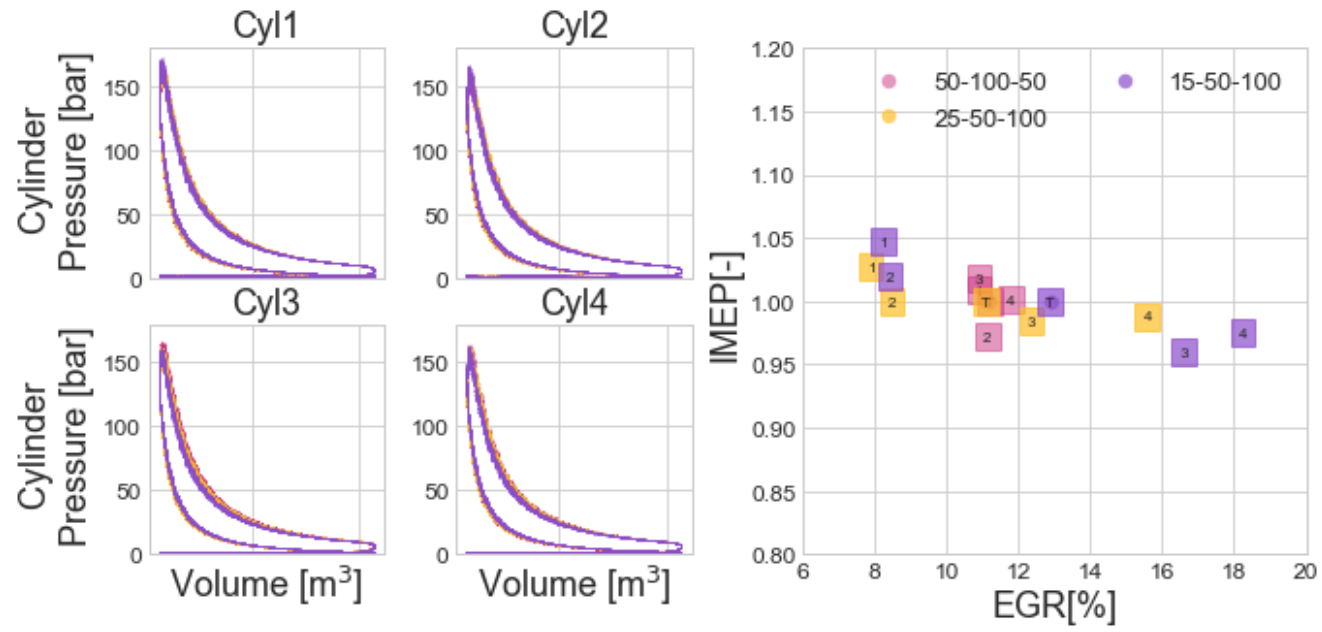

Figure 4.15. In-cylinder pressure vs cylinder displacement for all the cylinders and different dispersion levels (left) and IMEP for all the cylinders (numbered from 1 to 4 ) and the average (named T) versus EGR rate for different dispersion levels (right) at 1250, 1500, 2000, 2500 and 3000 rpm engine running conditions (from top to bottom).

\subsubsection{Influence on the exhaust gases composition}

Figure 4.16 presents normalized $\mathrm{O}_{2}$ (left) and normalized $\mathrm{CO}$ (right) both of them vs. EGR rate at 1250, 1500, 2000, 2500 and $3000 \mathrm{rpm}$ engine running conditions from top to bottom. These measurements correspond to the probes placed in the exhaust manifold, at the outlet of every cylinder and downstream the turbine. On the left, it is possible to observe how the trend is that the $\mathrm{O}_{2}$ 
decreases when the EGR rate increases. On the right, the trend is the opposite, the $\mathrm{CO}$ increases when the EGR rate increases.

The $1250 \mathrm{rpm}$ engine running condition does not present the value in each cylinder because, as it is was explained before, due to the vibrations and low stability of the running conditions it was not possible to measure the emissions cylinder to cylinder, only the raw emissions in the exhaust and the opacity because it needs only few seconds. Nevertheless, the results show the normalized raw emissions and they are presented cylinder to cylinder to remind the EGR rate per cylinder, in this way it is offered a visual inspection of the EGR rate per cylinder and the EGR standard deviation to compare with the other engine running conditions. Furthermore, it is possible to see how the case that presented before a huge opacity, breaking the trend, in Figure 4.8 and a very high BSFC value and very low lambda value in Figure 4.14 (25-25-50 green hexagon), now shows higher $\mathrm{CO}$ levels than the others, breaking the trend again but usual $\mathrm{O}_{2}$ values. This phenomenon is in agreement with the results observed in Figure 4.13, where this case presented usual air mass flow values, like the other cases, but higher fuel mass flow values than they are.

Moreover, it is possible to observe some particularities for some operation points. At $1500 \mathrm{rpm}$, the two cases with the highest standard deviation, which present low opacity values in Figure 4.8 (25-75-25 light green triangle and blue square) in this case show higher $\mathrm{O}_{2}$ values and lower $\mathrm{CO}$ values, breaking the trend of the rest of cases in that engine running condition. Furthermore, it is possible to appreciate that the two tests with highest opacity levels presented in Figure 4.8 offer the lowest $\mathrm{O}_{2}$ values and the highest $\mathrm{CO}$ values. All of that in agreement with Figure 4.13 too, where the cases which present higher air mass fraction and lower fuel mass fraction present too higher $\mathrm{O}_{2}$ values and lower $\mathrm{CO}$ values and vice versa. Obviously, it is in agreement with Figure 4.14 too, between BSFC and CO trends.

Similar effect, more clearly even, is perceptible at 2000, 2500 and $3000 \mathrm{rpm}$, where, once again, the tests with higher opacity values, lower air mass flow, higher fuel mass flow and higher BSFC offer lower $\mathrm{O}_{2}$ and higher $\mathrm{CO}$ values, and vice versa. 

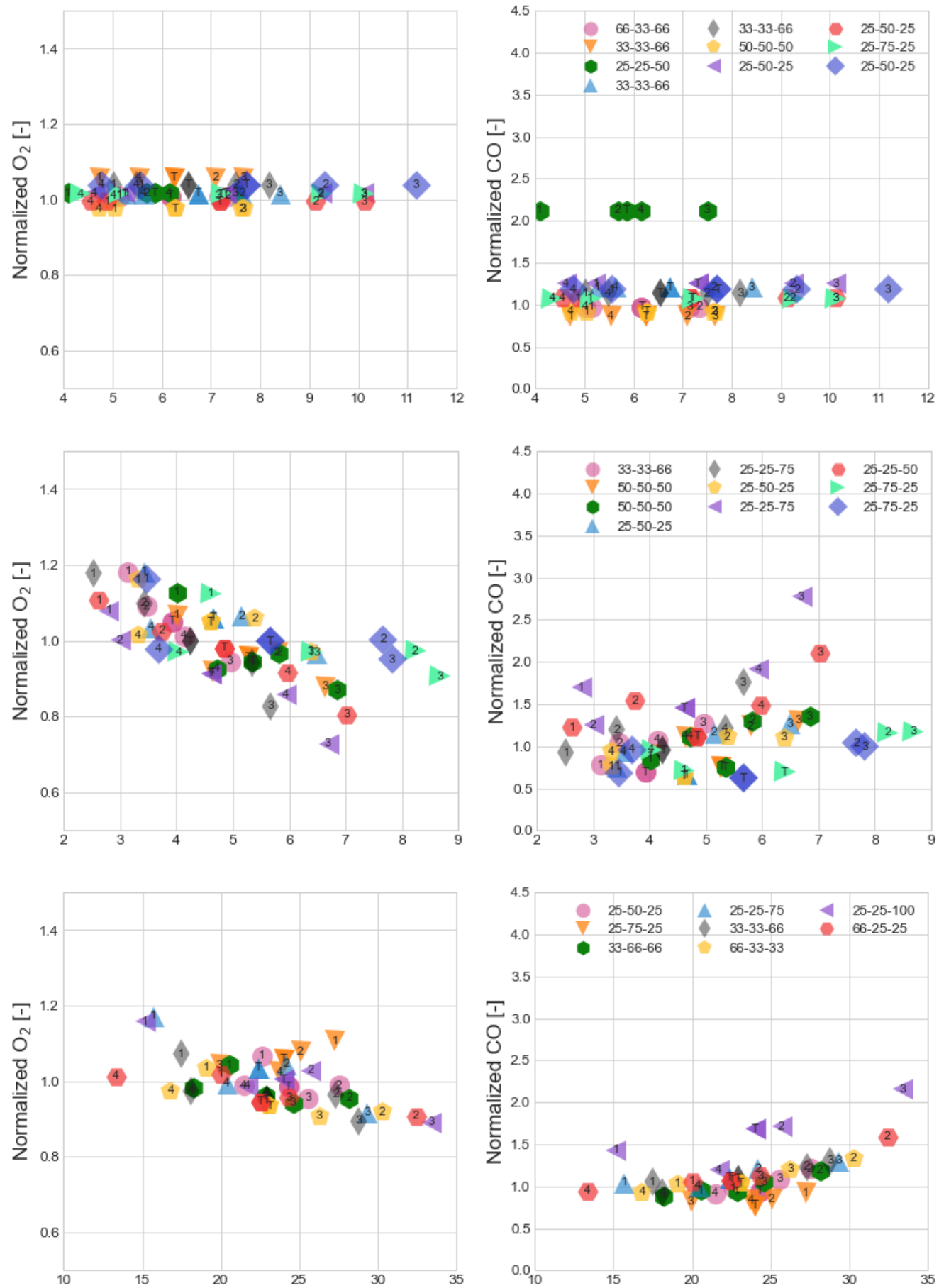

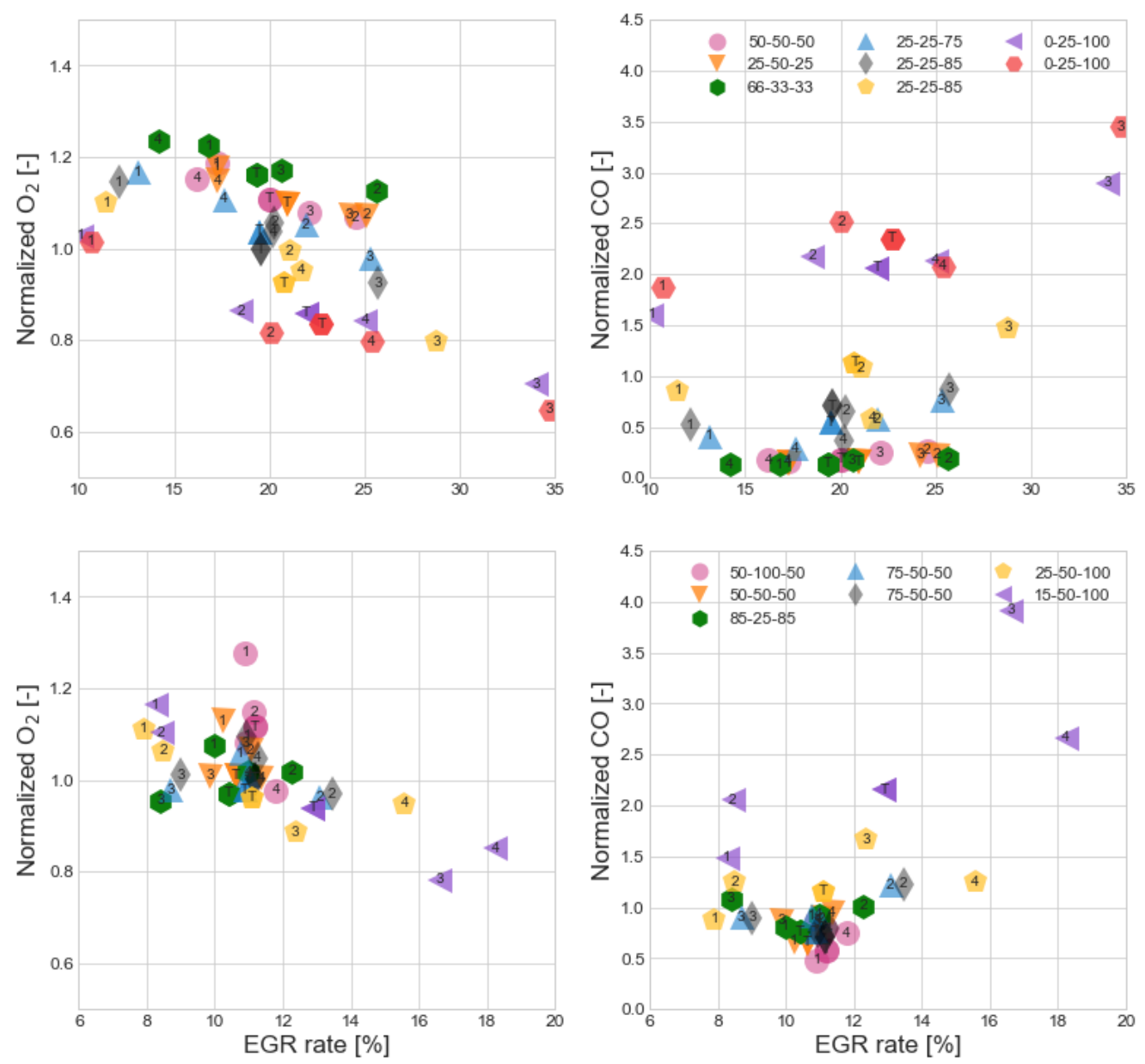

Figure 4.16. $\mathrm{O}_{2}$ vs. EGR rate (left), and CO vs. EGR rate (right) at 1250, 1500, 2000, 2500 and $3000 \mathrm{rpm}$ working operation points (from top to bottom).

\subsubsection{Dimensionless opacity}

Figure 4.17 shows lambda (left), the dimensionless BSFC that is calculated as the ratio between the BSFC and the BSFC achieved with the lowest EGR dispersion out of all engine running conditions (center) and the exhaust gases opacity as a function of the EGR dispersion. All of them in all the engine running conditions (1250, 1500, 2000, 2500 and $3000 \mathrm{rpm}$ ) and to all dispersion levels.

A reduction on the lambda values is observed as EGR dispersion increases, which can be explained mainly by two reasons: either changes in the air mass 
flow entering the cylinders or variations in the injected fuel. As already discussed in section 4.1.3 in the explanation of the Figure 4.7, an increment of EGR rate was necessary to maintain the NOx nominal value in the 1250, 1500, 2500 and $3000 \mathrm{rpm}$ engine running conditions, although the effect at $2500 \mathrm{rpm}$ is slight. The difference between the 1250, 1500 and 3000 working operation points and the other, 2000 and 2500, is the EGR rate. The former points have lower EGR rates, around 5-10\%, while the latter points have higher EGR rates, over $20 \%$. On the other hand, regarding the fuel injection, more fuel quantity is needed when the EGR dispersion increases in the 2500 and $3000 \mathrm{rpm}$ engine running conditions, which is easily detected in the BSFC plot. This means that the impact of the EGR dispersion on the combustion performance is more remarkable in these engine running conditions.

In Figure 4.17 another difference related to lambda value is detected. The engine running conditions at 1250,1500 rpm and $3000 \mathrm{rpm}$ are close to engine full load operation, as it is explained in section 4.1.2, and they present a lambda value lower than 1.25 , especially at $1250 \mathrm{rpm}$. While the other working operation points, $2000 \mathrm{rpm}$ and $2500 \mathrm{rpm}$, present values over 1.3, corresponding to engine partial load situation. When the engine approaches to stoichiometric conditions the combustion process in the cylinder become more critical.

Particularly, the $1250 \mathrm{rpm}$ engine running condition, with two different areas of EGR dispersion level, needs to increase the EGR rate, as the 1500 and 3000 rpm engine points, to keep the same NOx level. These two areas present an average EGR rate of around $6.3 \%$ and $7.4 \%$ in the low and high EGR dispersion level respectively. The EGR absolute value is not very high but the difference between both of them is considerable, since it presents an increment of $14.5 \%$. Moreover, this working operation point presents so low lambda values too, around 1.1, lower than 1500 and 3000 engine running conditions. Therefore, this working operation point is more extreme than 1500 and 3000 rpm working operation points. All of them present a low EGR rate and need to increase the EGR rate to keep the NOx level constant and the low lambda value, but in the $1250 \mathrm{rpm}$ engine running conditions, the limit situation is much closer. It explains clearly the anomalous case with huge opacity, fuel mass flow, BSFC and, therefore, the instability that made it impossible to measure cylinder to cylinder emissions. 
On the other hand, the graph of the center presents a clear trend between the increment of BSFC and the increment of the EGR dispersion. The 3000 and 2500 rpm engine running conditions show the highest increment of the BSFC: $3 \%$, from 1 to 1.03 , and $6.9 \%$, from 1.01 to 1.08 , respectively. The 1250 and $2000 \mathrm{rpm}$ running conditions present more modest increment than the other: $1.3 \%$ without taking into account the anomalous case, from 1.125 to 1.14 and $0.9 \%$, from 1.06 to 1.07 , respectively. Taking into account the anomalous case at 1250 the increment is much higher, of $5.8 \%$, from 1.125 to 1.19 that is at the same level than 3000 and 2500 rpm working operation points. Finally, the impact of the EGR dispersion on the specific consumption at $1500 \mathrm{rpm}$ working conditions is $1.5 \%$ from 1.03 to 1.045 , thanks to the cases with bad distribution between pipes explained in section 4.1 .3 and in Figures 4.9 and 4.10. Otherwise, the BSFC increment in this case would be imperceptible.

To finish, the graph on the right shows a scatter plot where opacity increases significantly with the EGR dispersion. At $1250 \mathrm{rpm}$ the opacity is $138 \%$ higher in the highest EGR dispersion dot than in the lowest, from 13 to $31 \%$, once again without taking into account the anomalous value. If the anomalous value is included, the increment is from 13 to 85, what implicates a $554 \%$. But it is necessary to take into account that this effect could be not only caused because of the EGR dispersion but because of the increase of the EGR rate and the very low lambda value too, very close to 1 , while the others present higher lambda values, around 1.1 .

The data for $1500 \mathrm{rpm}$ shows a very high increment of opacity, from 5\% to 33\%, what indicates an increment of $560 \%$. However, if the bad distribution EGR pipes cases are not taken into account, the increment would be very low compared with the results of the other engine running conditions, from $5 \%$ to $8 \%$, which would mean an increment of $60 \%$. It would be the lowest increment of the opacity among engine running conditions of this study. It is the working operation point with the lowest EGR standard deviation. In this case, as in 1250 $\mathrm{rpm}$, the absolute value of the EGR rate is low but there is an increment of EGR rate to keep NOx at constant level. As it was commented before in Figure 4.7 where it was shown that one of the points with the highest dispersion (light green triangle 25-75-25) operates with an EGR rate of $6.3 \%$, while the lowest dispersion case does with $3.9 \%$ of EGR rate, which means an increment of $62 \%$. 
In spite of the high increment of the EGR rate and the low lambda value, they have not big consequences in the opacity like at $1250 \mathrm{rpm}$, except the anomalous case at 1250 and the three cases which the bad distribution cause the increment of the opacity levels at 1500 .

The cases at 2000 and $2500 \mathrm{rpm}$ (low and medium load respectively) represent the highest opacity values without taking into account the anomalous value at $1250 \mathrm{rpm}$. The two cases offer higher EGR rates than the others and the first case does not need to increase the EGR rate to keep the NOx values constant due to the lower load and the stability of these engine running conditions, in the second case this effect is slight. Consequently, the EGR standard deviation achieved is higher than the others, especially at $2500 \mathrm{rpm}$ case. Paying attention to $2500 \mathrm{rpm}$ it is observed a decrease of the lambda values and an increase of BSFC more pronounced than the $2000 \mathrm{rpm}$ case. Therefore, it is possible to see a very clear trend: higher EGR dispersion among cylinders correlates with higher opacity levels.

The $3000 \mathrm{rpm}$ case also presents high opacity values, under the 2000 and 2500 rpm cases. The engine runs with a low lambda value in this operation point and medium EGR rate, around 11\%. This case presents a high increment of EGR standard deviation too, but lower than 2000 and $2500 \mathrm{rpm}$ cases too.

Finally, the opacity plot showed a very clear trend between the increment of the EGR standard deviation and the increment of the opacity. However, it is difficult to compare different cases with different EGR rates and EGR standard deviation values. 

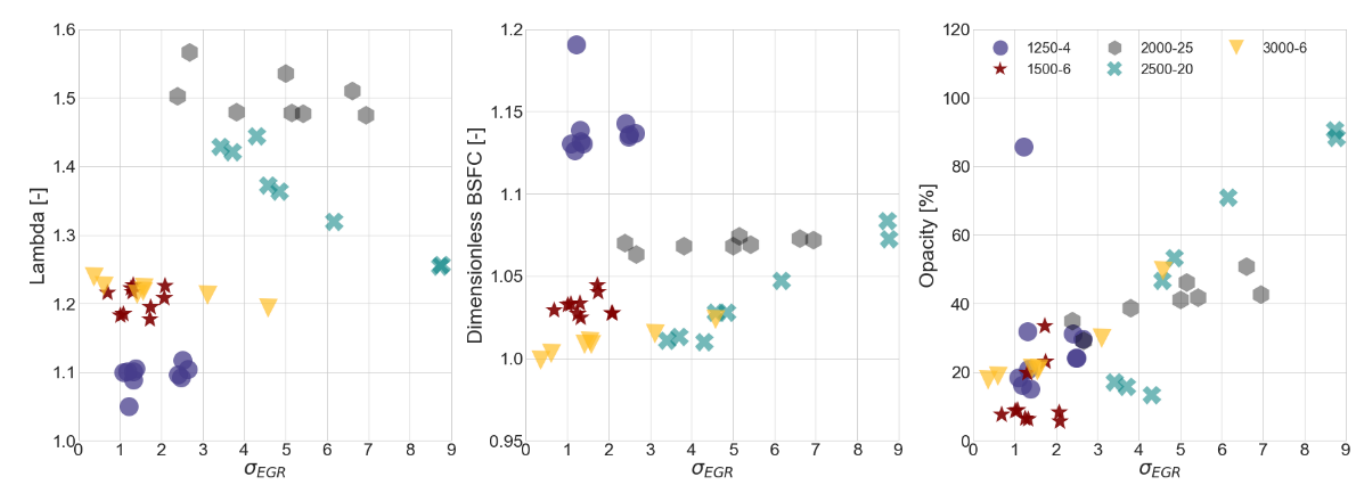

Figure 4.17. Lambda (left), dimensionless BSFC (center) and opacity (right) vs EGR dispersion at 1250, 1500, 2000, 2500 and $3000 \mathrm{rpm}$ engine running conditions.

Figure 4.18 gathers all the results in a single plot. Y-axis represents a dimensionless opacity that is calculated as the ratio between the opacity and the opacity achieved with the lowest EGR dispersion at the given engine running condition. X-axis represents the coefficient of variance of the EGR standard deviation, defined in section 3.3 in Chapter 3, which is calculated as the ratio between the EGR standard deviation and the average EGR rate. Over the symbols the actual opacity value in percentage is given.

Remembering the $1500 \mathrm{rpm}$ engine running condition, it is possible to see that the $\mathrm{X}$-axis distribution of the cases changes due to the dimensionless of the coefficient of variance effect. In fact, this was one of the engine running conditions that needed to increase the EGR rate to keep the NOx constant like 1250, 2500 and $3000 \mathrm{rpm}$, but proportionally the increment in this case is much higher than in the rest of cases and, because of that, the cases have been reorganized. Although the correlation between the opacity and the coefficient of variance is not so clear than in the other engine running conditions, now it is much more similar than before thanks to the dimensionless of coefficient of variance.

In addition, the anomalous opacity value at 1250 does not change significantly the position regarding to $X$-axis by the dimensionless effect of the coefficient of variance, on the contrary these anomalous case is still explained by the lowest lambda value effect. On the other hand, the other three engine running 
conditions keep the same trend than before, between opacity and EGR standard deviation, taking into account now the dimensionless effect of coefficient of variance.

The trend between the EGR dispersion and the opacity is perfectly clear to all engine running conditions. It is possible to realize that a remarkable increase in the dimensionless opacity appears for EGR dispersion coefficient values higher than 0.2 [1]. Y-axis scale shows that, depending on the engine running condition, the EGR dispersion phenomenon could multiply the opacity level for the lowest EGR dispersion by a factor around 1 and 5 .

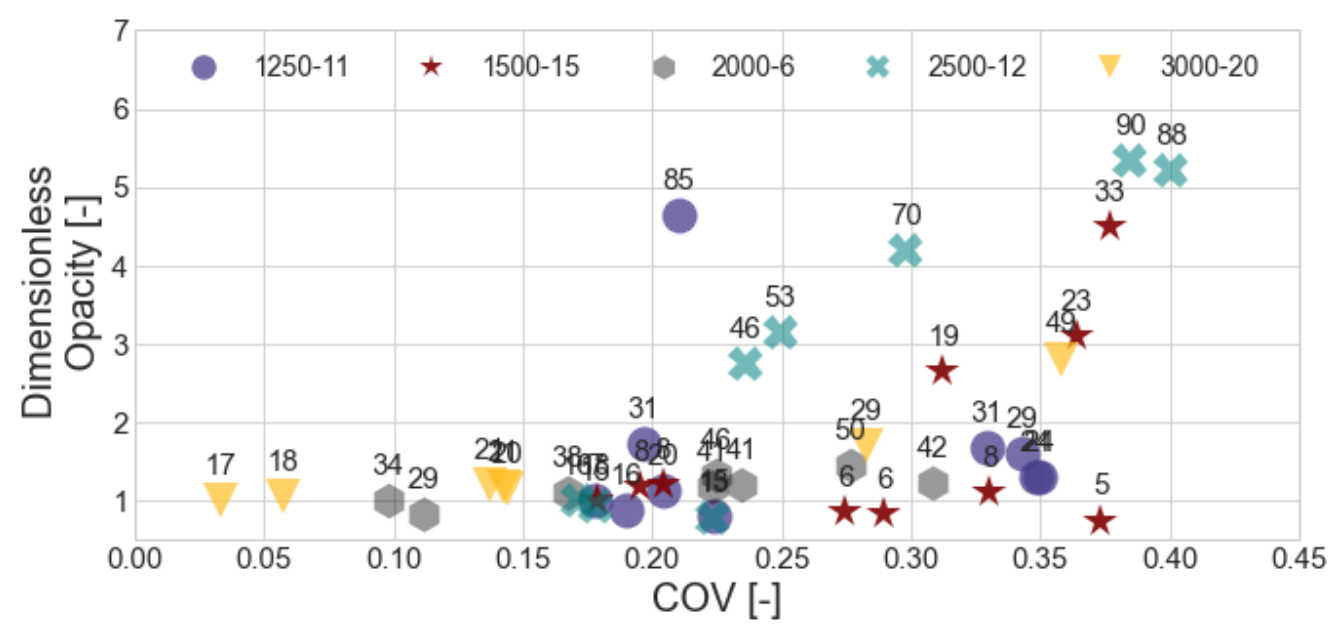

Figure 4.18. Dimensionless opacity vs coefficient of variance of the EGR standard deviation for all the tested engine running conditions.

\subsection{D model performance}

Once the methodology and modeling tools were explained in Chapter 3, and the necessary parameters to measure the capability of prediction and, to compare the different engine running conditions models among them, it is possible to analyze and discuss the results.

\subsubsection{Model assessment}

This section details the comparison between modeled and measured $\mathrm{CO}_{2}$ concentration with the fast tracking device. Even though this device is able to sample with higher frequency than the traditional gas analyzer, its time 
resolution provides an approximate value of $8 \mathrm{~ms}$, which is still far from crankangle resolution. Depending on the system settings and, mainly, engine speed, around ten points can be sampled in one engine cycle, 720 Crank Angle Degree. For this reason, the fast gas analyzer is measuring for several engine cycles (up to 200 consecutive cycles) and, under the assumption that the engine is running in steady condition, these measurements will fill the whole 720 Crank Angle Degree domain, as the following figures show.

The model assessment was performed by the experimental contribution of the preliminary study tests, detailed in Table 3.5 of the Chapter 3 and explained in section 4.1.1 in the current chapter.

Figure 4.19 presents the results for the $2500 \mathrm{rpm}$ and 19 bar BMEP engine running conditions, where the engine is operating with $4 \%$ EGR. Six plots are shown, corresponding to the measurements in the six locations described in Figure 3.11 in Chapter 3. The $\mathrm{CO}_{2}$ concentration is plotted against the crankangle degree. As stated before not all the measured points correspond to the same engine cycle. All the points are plotted in red with certain level of transparency. The red solid line corresponds to the average of all data, together with a light red band of two standard deviations wide (one above and one below the average values). The solid blue line corresponds to the predicted results provided by the $1 \mathrm{D}$ model. Together with the $\mathrm{X}$-axis, labels indicating the period of the intake strokes for the four cylinders are added, following the firing order of the engine (1-3-4-2).

From the experimental point of view, some relevant information is obtained from the results. The variation of the $\mathrm{CO}_{2}$ concentration along the engine cycle is reduced in locations \#5 and \#6, which are placed in the pipes of cylinder 4, since the air and EGR motion in that area should not be remarkable. Only when the intake valves of that cylinder open, a slight variation in the signals is observed. Locations \#3 and \#4 present slightly higher variations since they are placed in the pipes of cylinder 3 , and the flow motion in the intake manifold in front of the central cylinders should become relevant. Location \#1, which is placed in the intake manifold and not in the pipes, also reveals some variations in the $\mathrm{CO}_{2}$ concentration but not so significant because the probe is close to one lateral end of the manifold. On the other side, location \#2 is where the $\mathrm{CO}_{2}$ 
concentration shows the largest variations since the probe in this location is in the central zone of the manifold and flow stream lines probably go through this area when either cylinder 1 or 2 perform the intake process.
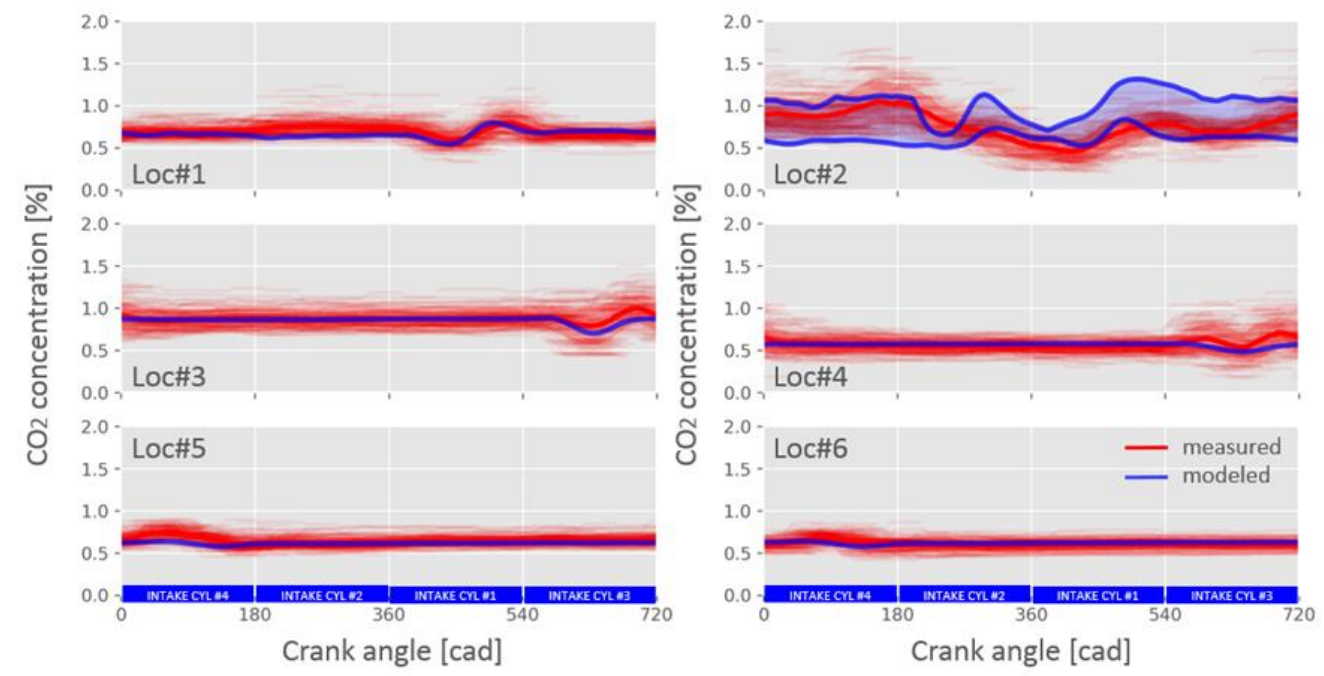

Figure 4.19. Instantaneous $\mathrm{CO}_{2}$ concentration in 6 locations of the intake manifold at $2500 \mathrm{rpm}$ and 19 bar BMEP with $4 \%$ of EGR rate working operation point.

Regarding the comparison between experiments and the model prediction, it should be noted that the 1D model is able to reproduce with a good level of agreement the $\mathrm{CO}_{2}$ concentration evolution in all the tested locations except location \#2. The plot in location $\# 2$ includes the modeling results in two places of the intake manifold. Both plots correspond to the closest pipe and closest volume to the measurement probe. Since the fluid dynamics inside the intake manifold follow a highly 3D pattern, a 1D engine model is not able to capture the concentration evolution in the same way that it is observed for other locations, which are placed in the pipes or in the lateral end of the manifold. However, it is observed that the experimental data falls between the chosen model places.

If Figure 4.19 constituted an example of engine full load conditions, Figures. 4.20, 4.21 and 4.22 represent partial load (2500 rpm and 10 bar BMEP with 17\% of EGR), low load (1500 rpm and 3 bar BMEP with 3\% of EGR) and very low 
load conditions (1500 rpm and 1 bar BMEP with $42 \%$ of EGR), respectively, as it was explained in the engine map in Figure 4.1. The two last examples are both low load engine conditions but they have been chosen because they operate with very different EGR rates so the model performance in extreme situations can be assessed.

Focusing on Figure 4.20, similar messages to those observed in Figure 4.19 may apply. Firstly, location \#2 presents again the largest $\mathrm{CO}_{2}$ variations during the engine cycle, although, in this case, with $17 \%$ of EGR rate, the fluctuations in the intake manifold are lower (in relative terms) than those observed in Figure 4.19 , with $4 \%$ of EGR rate. And secondly, the $1 \mathrm{D}$ engine model is able to capture the signal evolutions, except for location \#2.
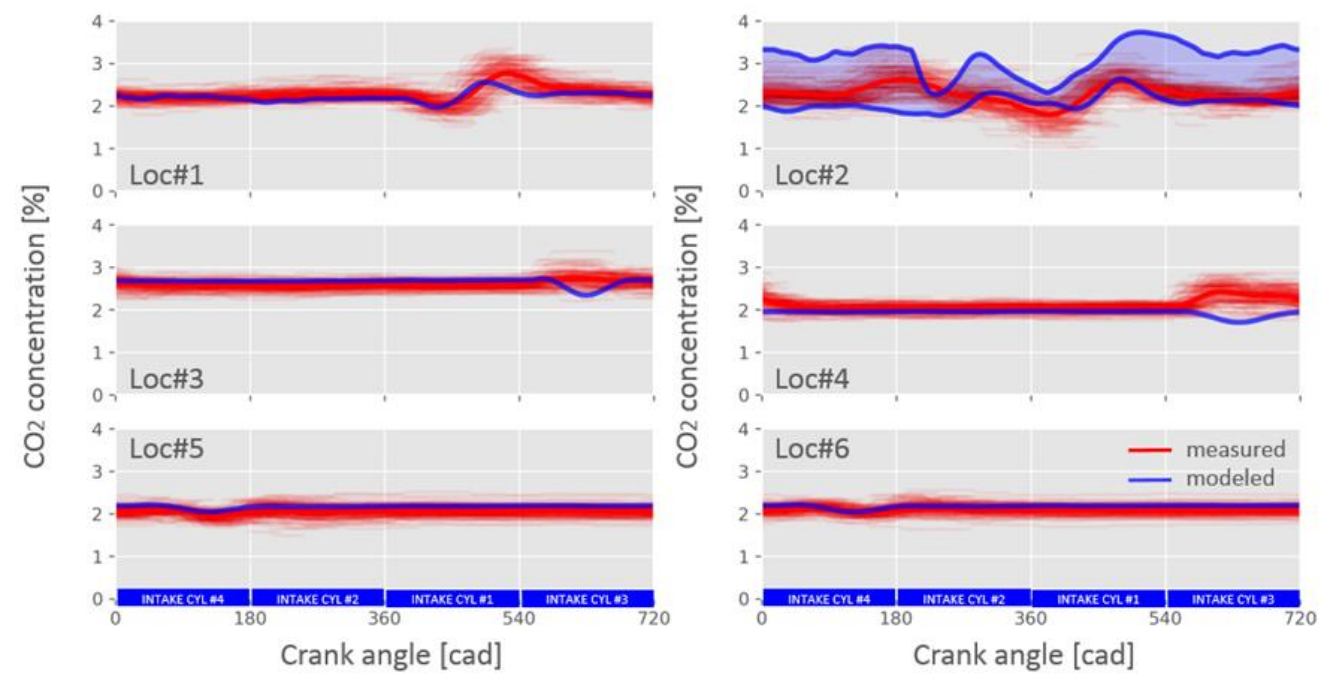

Figure 4.20. Instantaneous $\mathrm{CO}_{2}$ concentration in several location of the intake manifold at $2500 \mathrm{rpm}$ and 10 bar BMEP with $17 \%$ of EGR rate working operation point.

Figure 4.21 presents the results for low load working operation point (1500 rpm and 3 bar BMEP) with a very reduced EGR rate (3\%). This EGR rate is not the one typically found in real engines but was tested to confront the modeling results. On the other hand, a low load and high EGR rate $(42 \%)$ is found in Figure 4.22, where the engine is running at $1500 \mathrm{rpm}$ and 1 bar BMEP. Similar conclusions as the described before are derived from the plots. 

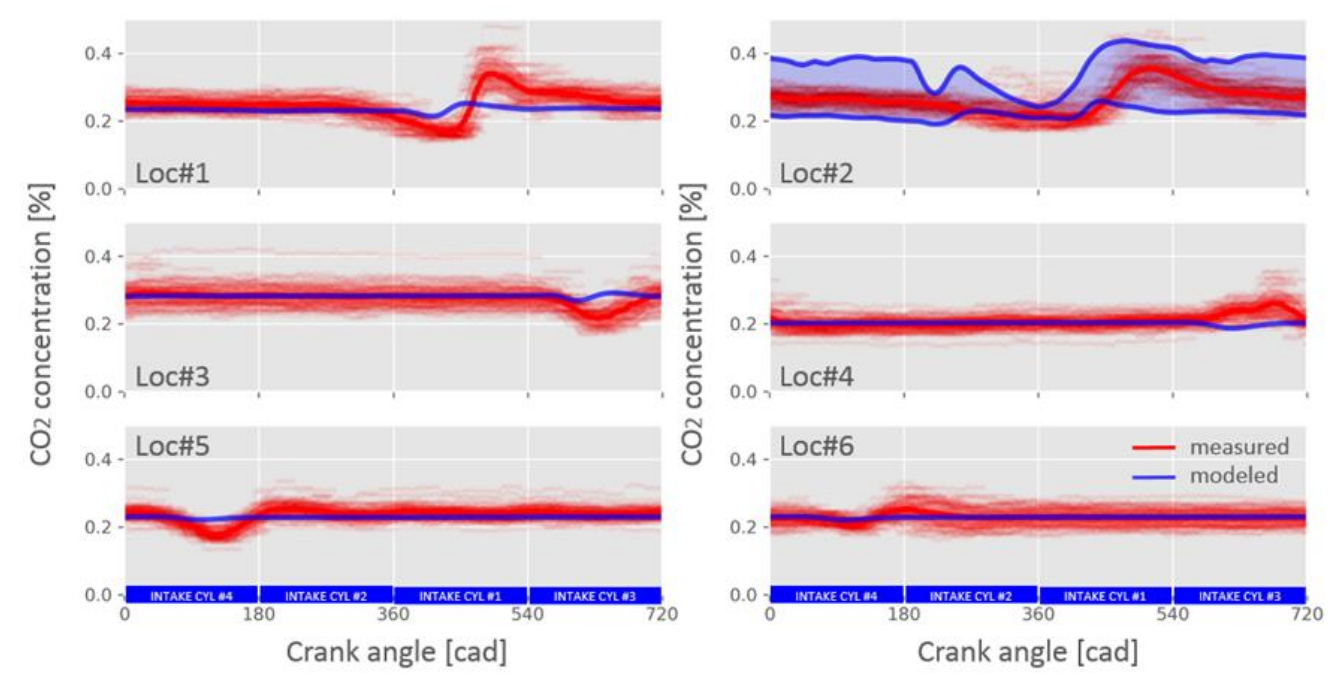

Figure 4.21. Instantaneous $\mathrm{CO}_{2}$ concentration in several location of the intake manifold at $1500 \mathrm{rpm}$ and 3 bar BMEP with 3\% of EGR rate working operation point.

One additional comment would arise when observing the $\mathrm{CO}_{2}$ traces in front of cylinder 3 , i. e., locations \#3 and \#4. During the intake process in cylinder 3 , the $\mathrm{CO}_{2}$ concentration behaves oddly: sometimes a drop occurs, sometimes there is an increase, and sometimes there is an increase after an initial drop. This behavior does not happen equally in both pipes of cylinder 3 , as can be observed in Figures 4.21 and 4.22, where location \#3 starts with a reduction in the $\mathrm{CO}_{2}$ concentration while location \#4 initiates with a slight increase. The local fluid dynamics phenomena may be the root cause for this behavior and the 1D model is not always capable to capture. For instance, the evolutions in low load engine conditions with high EGR rate shown in Figure 4.22 present the opposite behavior: measured $\mathrm{CO}_{2}$ concentration in location \#3 presents a sudden reduction while the model predicts an increase; however, location \#4 reveals the opposite performance. It is important to keep this in mind because the predictive model capability for the cylinders EGR dispersion will be determined by the ability to reproduce the $\mathrm{CO}_{2}$ concentration in the pipes during the intake stroke; a perfect match between model and experimental data while the intake valves are closed does not necessarily mean a good EGR dispersion prediction. 
Another important remark that derives from the observation of empirical data is that there is always a presence of $\mathrm{CO}_{2}$ in the pipes, even in the situations when the engine is running with very low EGR rates ( $3 \%$ and $4 \%$ ), as it is observed in Figures 4.19 and 4.21. The concentration in the pipes of the lateral cylinders provides nearly constant values while the central cylinders present higher fluctuations, with ranges that move from $50 \%$ over the average value, when the engine is running with high EGR rates, to $100 \%$ when the EGR rate is reduced.
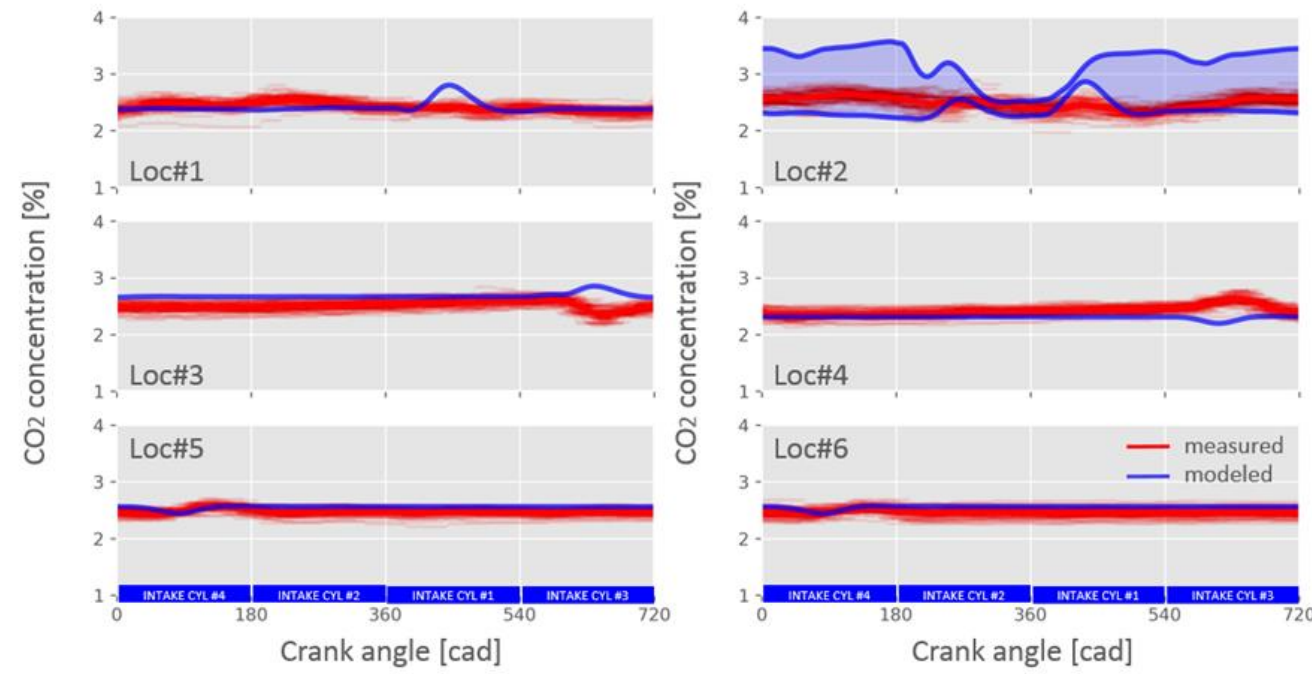

Figure 4.22. Instantaneous $\mathrm{CO} 2$ concentration in several location of the intake manifold at $1500 \mathrm{rpm}$ and 1 bar BMEP with $42 \%$ of EGR rate working operation point.

\subsubsection{Influence of the manifold layout modeling}

Figure 4.23 shows the EGR rate pipe to pipe at two engine running conditions, 2500 and 11.7 bar BMEP with 19\% of EGR rate and $3000 \mathrm{rpm}$ and 20 bar BMEP with $11 \%$ of EGR rate, from top to bottom, with different EGR dispersion valves position, 25-25-75 and 25-50-100 respectively. Each plot offers a comparison between a conventional and the new design of the manifold.

The performance of the new design was explained before, in the section 3.1 in Chapter 3, and a large number of volumes and ducts composes it. The conventional design is based on a big volume where the intake air and the EGR 
fall into and then the mix flow along 8 ducts, composed by various sections, up to the cylinders.

Both plots illustrate that the conventional design is not capable to predict the EGR distribution among pipes, not even partially. The spatial pattern of the EGR distribution among pipes presented by the conventional design is completely flat. On the other hand, the new design in both cases offers an asymmetrical distribution trying to predict the experimental EGR dispersion among cylinders.

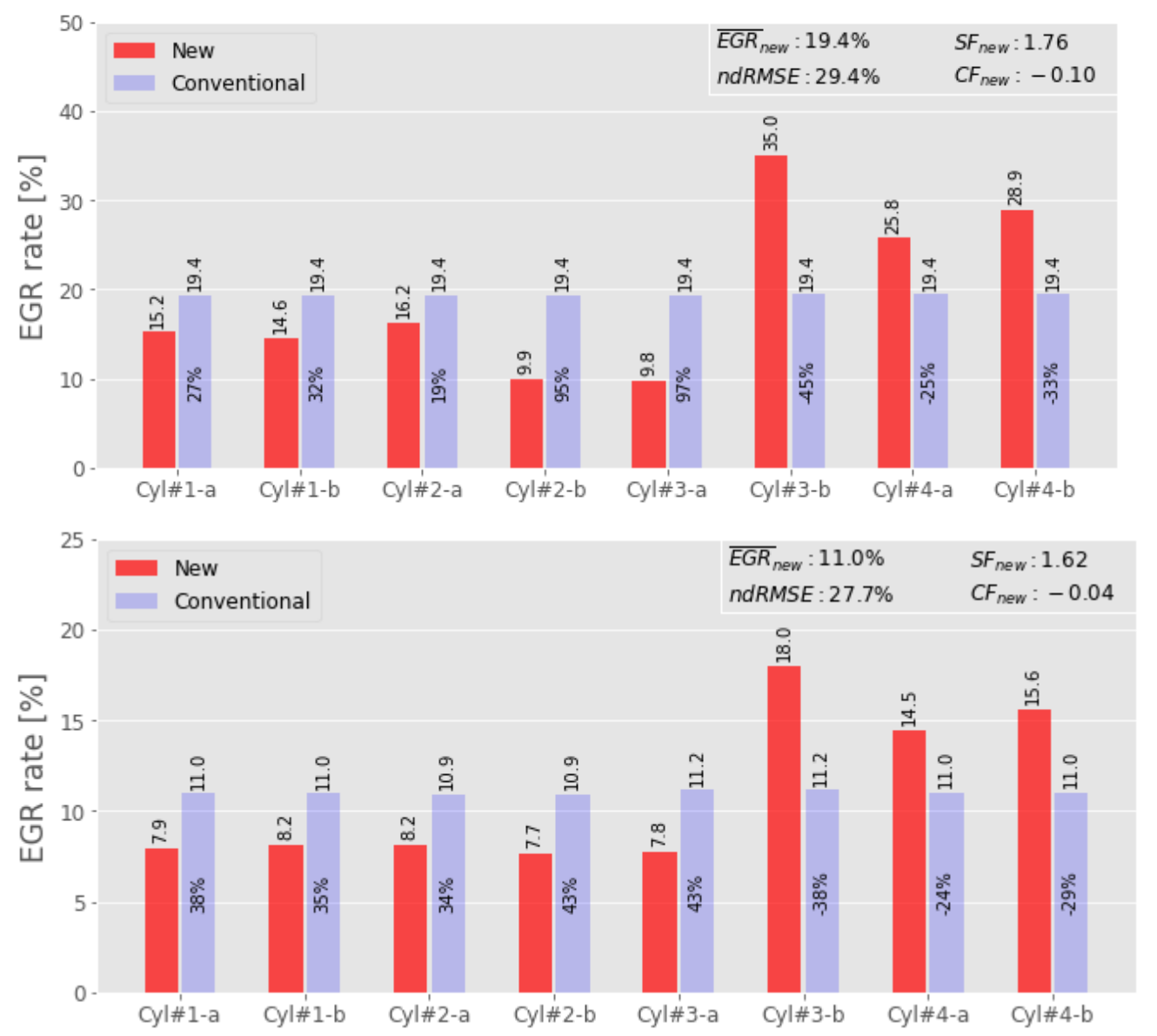

Figure 4.23. EGR rate pipe to pipe vs. pipes at $2500 \mathrm{rpm}$ and $11.7 \mathrm{bar}$ BMEP with $19 \%$ of EGR rate and $3000 \mathrm{rpm}$ and 20 bar BMEP with 11\% engine running conditions with different EGR dispersion valves control position, 25-25-75 and 25-50-100 respectively. Each one for two different manifold designs, a new one used in this study and a conventional. 


\subsubsection{Influence of wave dynamics}

Figures 4.25, 4.25, 4.26 and 4.27 show two different modeling operation points at $2000 \mathrm{rpm}$ and 6 bar BMEP with 23\% of EGR rate and $2500 \mathrm{rpm}$ and $11.7 \mathrm{bar}$ of BMEP with $20 \%$ of EGR rate with different EGR dispersion level, 25-25-75 and 50-50-50 respectively. Moreover, the length of the EGR duct has been modified to check if the wave dynamics affects to EGR dispersion or not. The length of the duct of the reference point, named "Original", is $85 \mathrm{~mm}$, which is the geometry based on the experimental installation and corresponds to a piece of pipe with that length. Furthermore, this length was incremented to $500 \mathrm{~mm}$ and $1000 \mathrm{~mm}$ to analyze the influence of the wave dynamics on the dispersion. It means an increase of up to $1075 \%$, close to 12 times longer than the original $85 \mathrm{~mm}$ piece in the longest case. The total original length of the EGR line is 1350 $\mathrm{mm}$, so it represents an increment of $75 \%$ in the longest case. A $1 \mathrm{D}$ model is perfectly reliable concerning to wave dynamics study.

Figure 4.24 shows the instantaneous air and EGR mass flow in the intake line (just before the manifold) and in the EGR line (just before the EGR valve) respectively, and instantaneous air mass fraction and EGR mass fraction in in the volume where both mass flows discharge and mix, which is the location of the manifold furthest from the cylinders. All of them with the different EGR line lengths at $2000 \mathrm{rpm}$ working operation point. The three different EGR line lengths are represented. The original length of the pipe, $85 \mathrm{~mm}$ (red); the first increment, $500 \mathrm{~mm}$ (green); and the second increment, $1000 \mathrm{~mm}$, (blue).

It is possible to see that the EGR mass flow wave in the EGR line is different according to the length of the EGR line. Even there is a gap among the cases. Between the original case and the $500 \mathrm{~mm}$, the period of the waves are delayed around $15^{\circ}$. Meanwhile, between the original case and the $1000 \mathrm{~mm}$, the period of the waves are displaced up to $35^{\circ}$. Moreover, the amplitude of the waves changes too, the maximum and the minimum in the original case are 0.010 and $0.005 \mathrm{~kg} / \mathrm{s}$ respectively. In the second case, the $500 \mathrm{~mm}$ of length, the maximum and the minimum are 0.016 and $0.0002 \mathrm{~kg} / \mathrm{s}$. Finally, the maximum and the minimum of the wave in the $1000 \mathrm{~mm}$ case are between $0.017 \mathrm{~kg} / \mathrm{s}$ and -0.0039 $\mathrm{kg} / \mathrm{s}$, in this last case the wave presents even negative values. The negative value implies that there is a backflow. It is obvious that the modification of the 
EGR line length affects to the wave dynamics of the EGR in that location, far from the intake manifold.

On the other hand, paying attention to the second plot, the waves in the intake line are identical, independently of the EGR line length. That it is reasonable due to the wave dynamics in the EGR line is not involved with the wave dynamics in the intake line. Moreover, similar effect takes place in the volume, where the waves of the EGR and the air, represented in the third and fourth graphs respectively, are overlapped and practically there are not remarkable differences independently of the length of the EGR line.
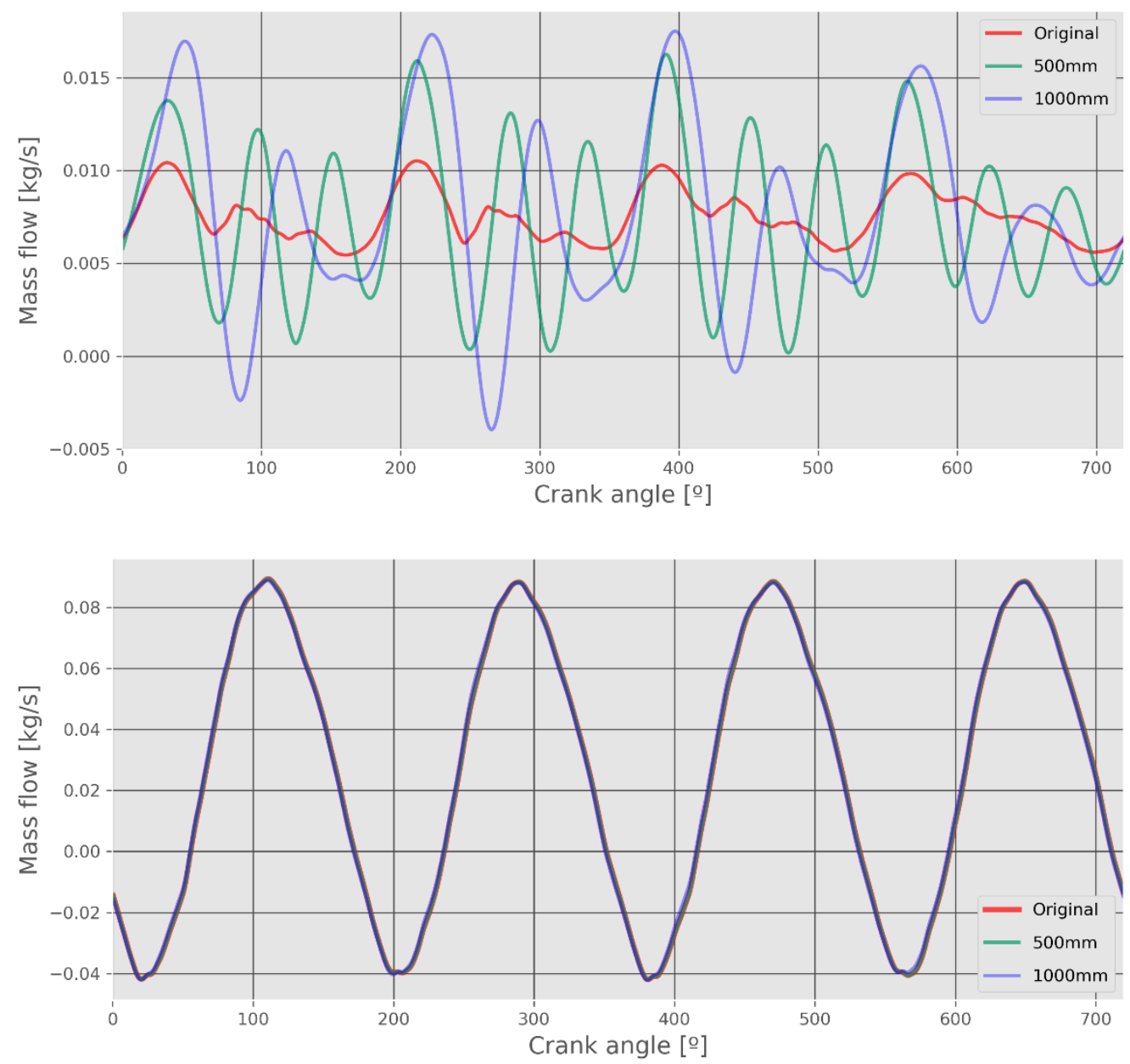

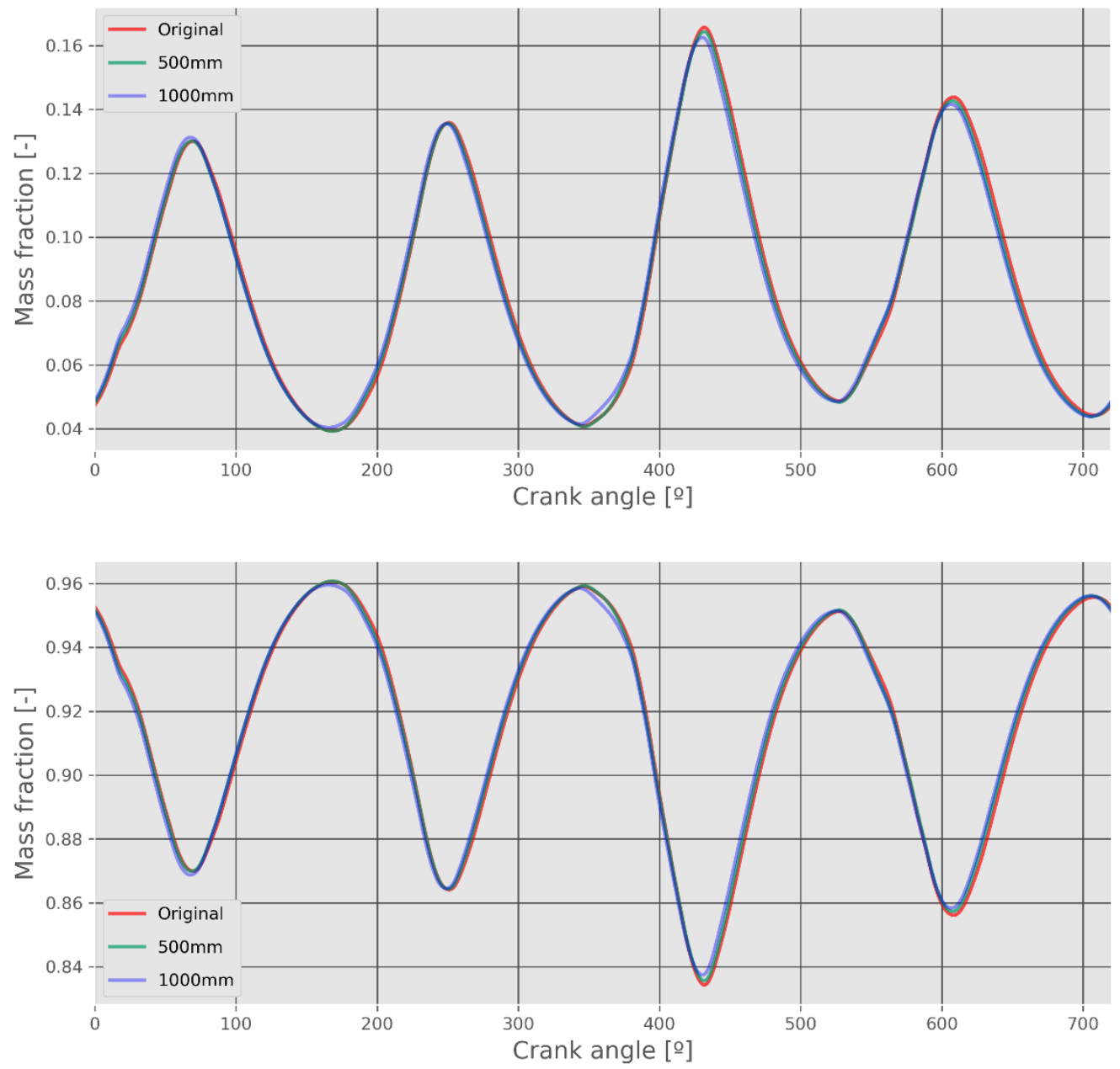

Figure 4.24. EGR and air mass flow in the EGR and intake lines respectively and, EGR and air mass fraction in the volume where they mix, respectively with three different lengths of the EGR line, including the original, at $2000 \mathrm{rpm}$ and 6 bar BMEP working operation point with 23\% of EGR rate. Y-axis represents the mass flow in the first two graphs and the mass fraction in the last two graphs, $\mathrm{X}$-axis represents the crank angle.

Figure 4.25 is very similar to Figure 4.24 , it shows the same parameters but at $2500 \mathrm{rpm}$ working operation point. The three different EGR line lengths are represented too, as in Figure 4.24. The colors and the increment of the dimension of the EGR line length are the same. The order of the plots is the same than previously in Figure 4.24 too. 
In this figure, between the original case and the $500 \mathrm{~mm}$ extra length case, the period of the waves of the EGR mass flow in the EGR line are displaced around $25^{\circ}$. Meanwhile, between the original case and the $1000 \mathrm{~mm}$ extra length case, the period of the waves are displaced up to $38^{\circ}$. Regarding the amplitude of the waves, the maximum and the minimum in the original case are 0.017 and 0.008 $\mathrm{kg} / \mathrm{s}$ respectively. In the second case, the $500 \mathrm{~mm}$ of length, the maximum and the minimum are between 0.028 and $-0.005 \mathrm{~kg} / \mathrm{s}$. Like before, the negative values means that there are even backflows. Finally, the amplitude of the wave in the $1000 \mathrm{~mm}$ case the maximum and the minimum of the waves are between $0.032 \mathrm{~kg} / \mathrm{s}$ and $-0.012 \mathrm{~kg} / \mathrm{s}$, it implies even a higher backflow than the $500 \mathrm{~mm}$ case.

Once again, the modification of the EGR line length affects to the wave dynamics of the EGR mass flow in the EGR line, but paying attention to the rest of plots, apparently it has not consequences. The waves in the intake line and in the volume where the two flows mix with each other are overlapped again, as already discussed before.

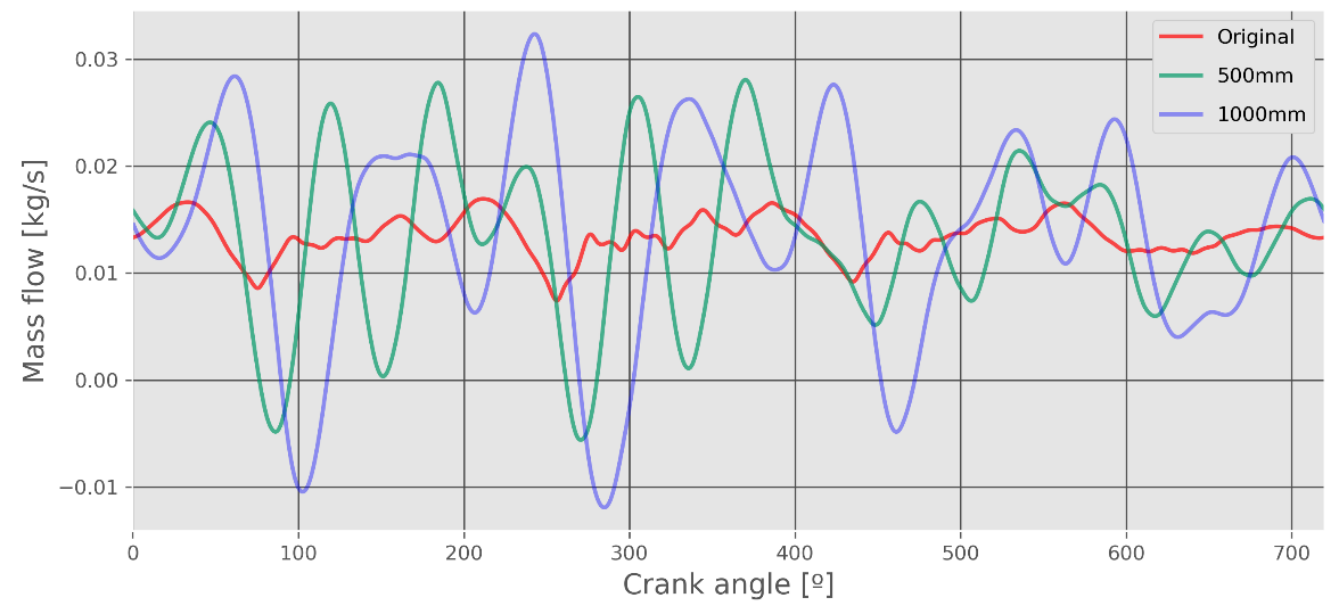



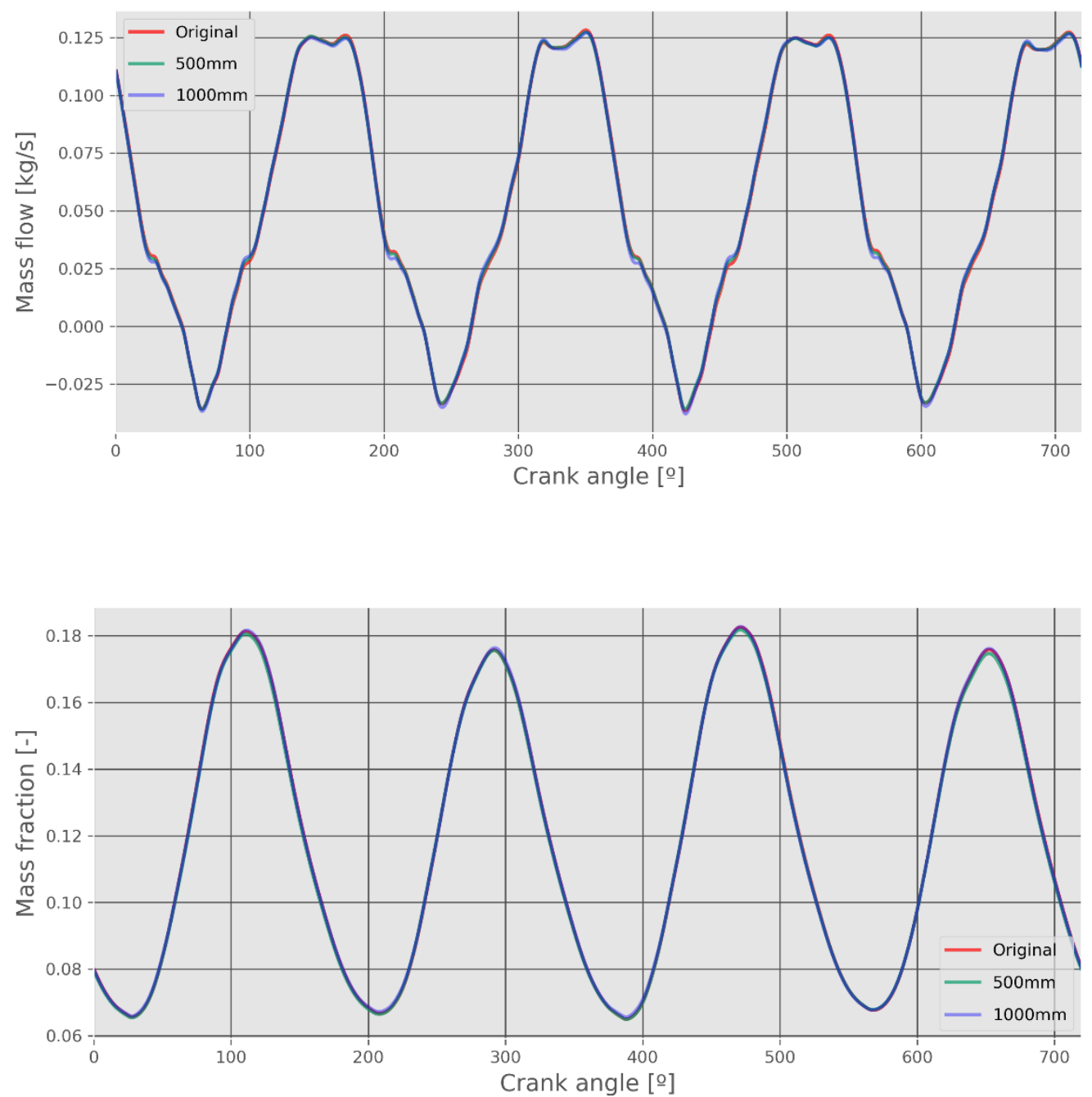


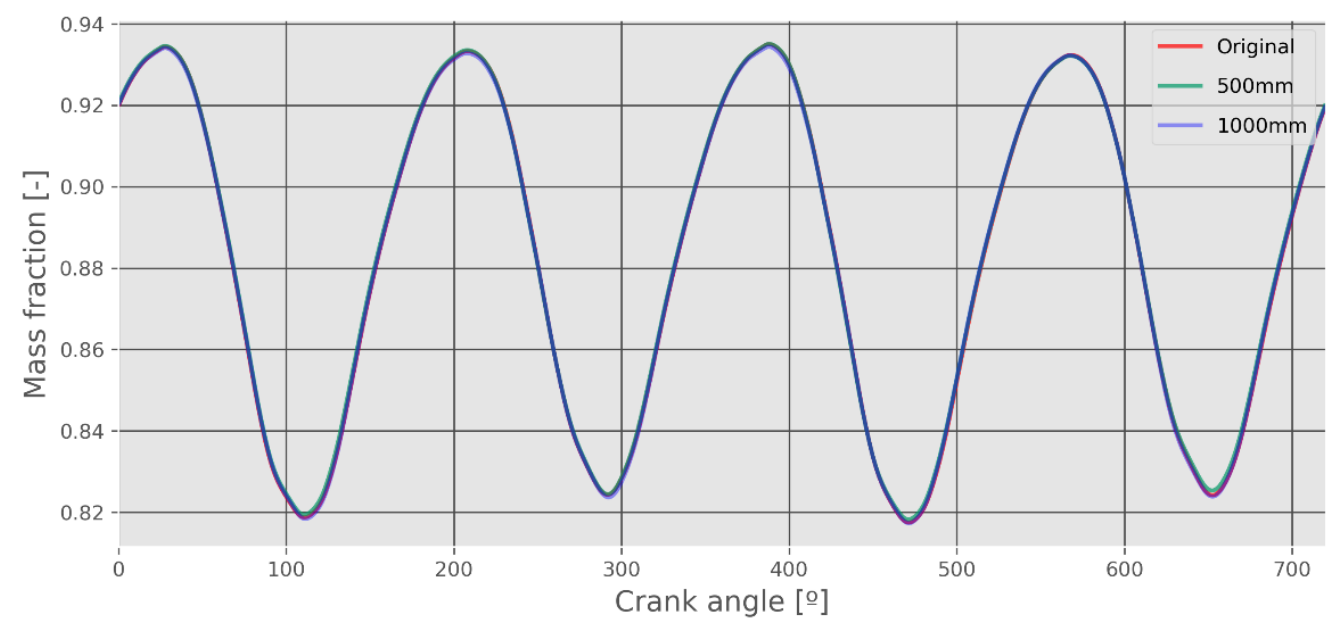

Figure 4.25. EGR and air mass flow in the EGR and intake lines respectively and, EGR and air mass fraction in the volume where they mix, respectively with three different lengths of the EGR line, including the original, at $2500 \mathrm{rpm}$ and 11.7 bar BMEP working operation point with $20 \%$ of EGR rate. Y-axis represents the mass flow in the first two graphs and the mass fraction in the last two graphs, $\mathrm{X}$-axis represents the crank angle.

Due to the wave displacement in the EGR line, the EGR mass flow was extracted from a subsequent location in the EGR line. Figure 4.26 shows the EGR mass flow at 2000 and $2500 \mathrm{rpm}$ engine running conditions from top to bottom respectively. If they are compared with the EGR mass flow presented in Figures 4.24 and 4.25 it is possible to see that the waves of the different lengths are more similar among them than before. It will go on with this trend until overlap themselves long before the arrival to the intake manifold.

This effect indicates that the exhaust pulses command the wave dynamics in the EGR line when it is closer from the exhaust, but it obeys the intake pulses according the flow approaches to the intake. 

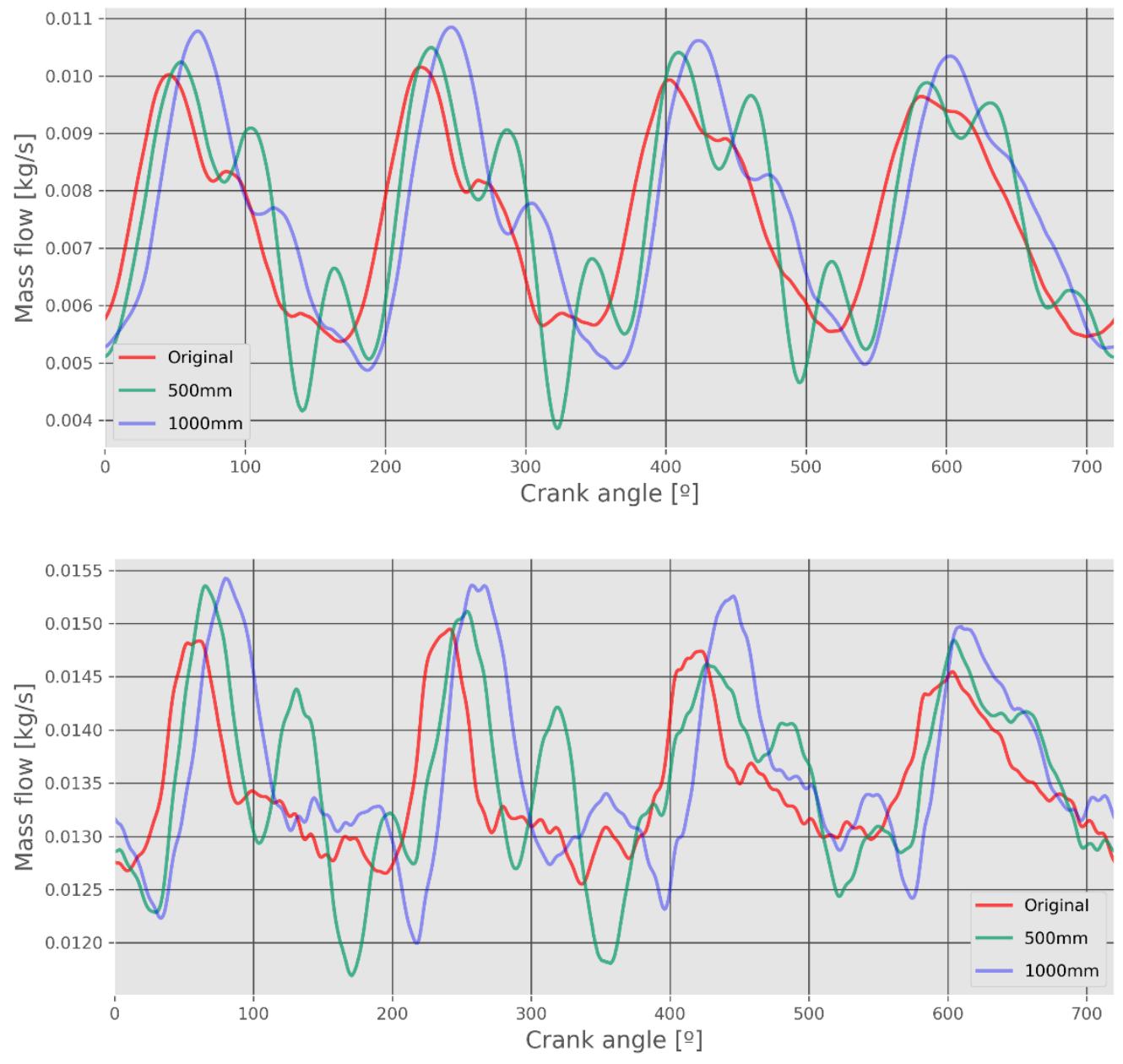

Figure 4.26. EGR mass flow in the EGR with three different lengths of the EGR line, including the original, at $2000 \mathrm{rpm}$ and 6 bar BMEP with 23\% of EGR rate and $2500 \mathrm{rpm}$ and 11.7 bar BMEP with $20 \%$ of EGR rate working operation points (from top to bottom). Y-axis represents the mass flow and $\mathrm{X}$-axis represents the crank angle.

In Figure 4.27 it is possible to see that, in spite of the variations of the EGR waves looked in Figures 4.24 and 4.25 in the EGR line, the modification of the length of the EGR line does not affect to the distribution of the EGR rate among pipes. Moreover, in the graphs of the Figures 4.24 and 4.25 which show the air and EGR waves in the volume where they mix, is possible to observe that the previous gap in the EGR line does not influence after that, in the volume, where 
the waves of the different lengths are overlapped. Therefore, it is reasonable that it does not change after, in the EGR distribution.

In both cases, the differences among cases with different lengths are lower than $1 \%$ in total. Moreover, the worst case among pipes is a difference of $2 \%$ compared to the original.
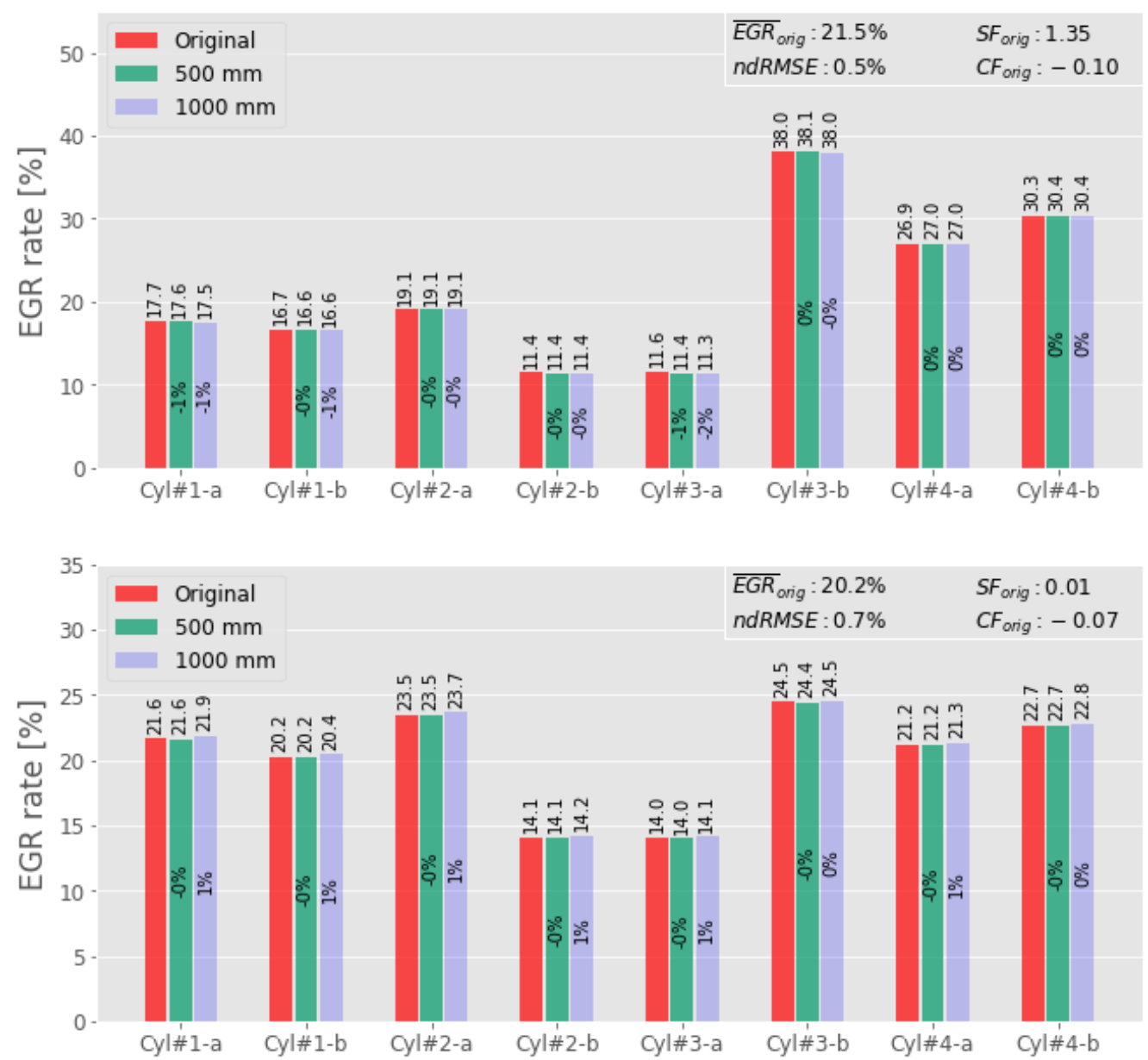

Figure 4.27. Modeled EGR rate vs. pipes at $2000 \mathrm{rpm}$ and 6 bar BMEP with $23 \%$ of EGR rate and $2500 \mathrm{rpm}$ and 11.7 bar BMEP with $20 \%$ of EGR rate working operation points. Both of them were simulated with different EGR duct length including the original. 


\subsubsection{Influence of the size of the manifold}

One big volume and eight ducts compose the conventional manifold design. The new manifold design is composed by several smaller volumes. In the model, volumes could slow down the flow depending on its size. Because of that, some tests were re-simulated to reduce this effect and evaluate the possible influence over the EGR distribution among pipes.

The volume of the conventional intake manifold design was reduced by 100 times to limit the slow down effect. It enhances the effect of the constant movement of the ducts too, which is determined by the suction of the cylinders. In this way it is possible to see if the volumes of the intake manifold could interfere in the EGR distribution in the model.

Figure 4.28 shows the air mass fraction (top) and EGR mass fraction (bottom) in the volume where they mix at $1500 \mathrm{rpm}$ and 15 bar BMEP with 5\% EGR rate working operation point with the conventional intake manifold design (red) and the smaller conventional intake manifold (blue). It is possible to observe that, with the smaller manifold, the amplitude of the wave increases significantly. However, the inflexion points of the waves do not change the position, although in the case of the reduced manifold the wave is splitted in two, one bigger and other smaller, and even at certain times the EGR mass fraction is zero, but it keeps the periodicity showed by the conventional manifold. Therefore, it is possible to say that, even with a reduced volume trying to limit the slow down effect, the suction of the cylinders does not change the phase of the waves. 

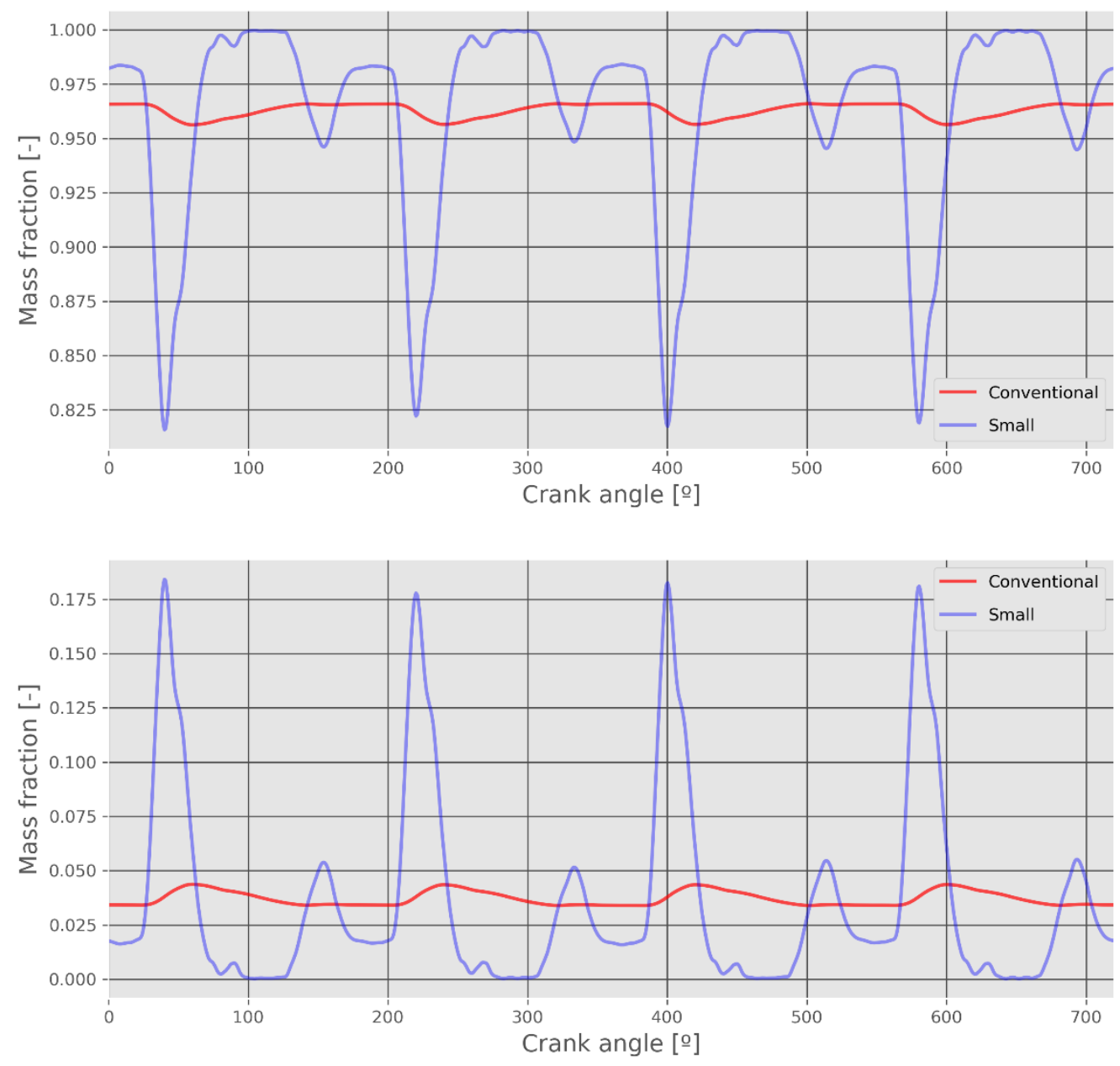

Figure 4.28. Air and EGR mass fraction in the volume where they mix at 1500 rpm and 15 bar BMEP with 5\% EGR rate working operation point in two different designs: conventional intake manifold design and smaller manifold. $\mathrm{Y}$-axis represents the mass fraction and $\mathrm{X}$-axis represents the crank angle.

In Figure 4.29 it is possible to observe the results of the prediction of the dispersion reducing the size of the conventional intake manifold at $1500 \mathrm{rpm}$ and 15 bar BMEP with 5\% of EGR rate, $2500 \mathrm{rpm}$ and 11.7 bar BMEP with 20\% of EGR rate and $3000 \mathrm{rpm}$ and 20 bar BMEP with $11 \%$ of EGR rate. All of them with different EGR dispersion levels, 33-33-66, 50-50-50 and 25-50-100 respectively. As Figure 4.29 shows, the modification of the volume of the conventional manifold has not a better predictive effect of the dispersion. It is 
possible to see that the dispersion changes practically nothing at 3000 and 1500 rpm, and absolutely nothing at $2000 \mathrm{rpm}$. At 1500 and $3000 \mathrm{rpm}$ it does not change too much and it does not approach to the experimental results or modeling results, with the new design, significantly. Even reducing the volume of the manifold, it presents the same EGR dispersion than conventional manifold, commented in section 4.2.2.

Therefore, it is possible to say that the volume size in the conventional layout of the intake manifold does not interfere in the EGR distribution in the model.
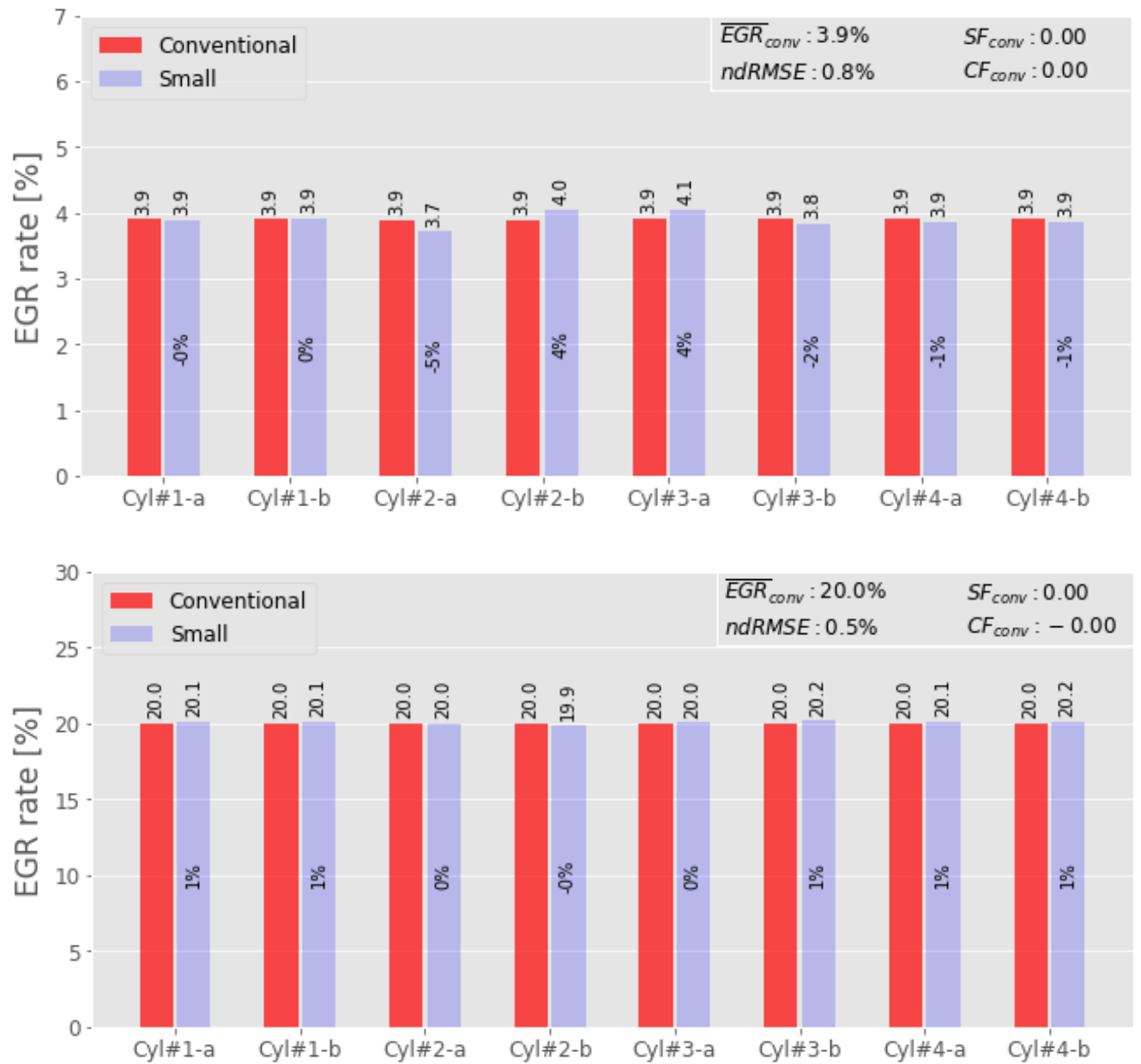


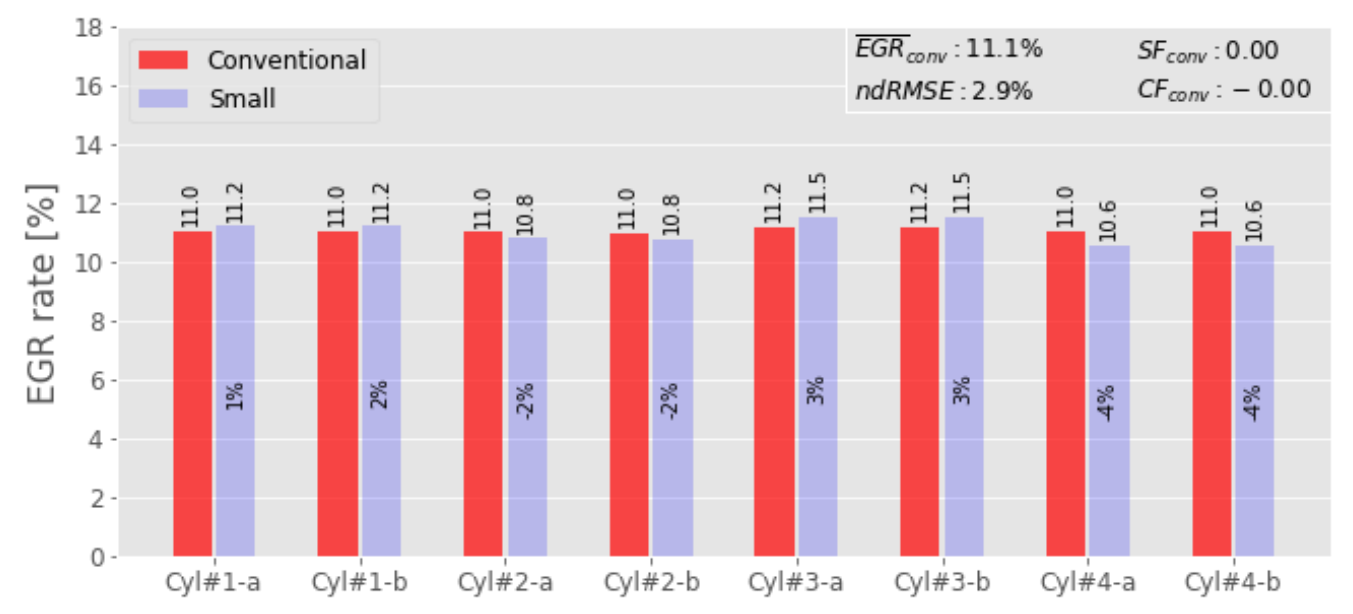

Figure 4.29. $1500 \mathrm{rpm}$ and 15 bar BMEP with 5\% of EGR rate, $2500 \mathrm{rpm}$ and 11.7 bar BMEP with $20 \%$ of EGR rate and $3000 \mathrm{rpm}$ and 20 bar BMEP with $11 \%$ of EGR rate with different levels of EGR dispersion, simulated with two different conventional intake manifold sizes. Y-axis represents the EGR rate and X-axis represents the number of the pipes where the flow runs.

\subsubsection{Results with controlled EGR dispersion}

Next figures expose measured and predicted EGR rate in the intake pipes at five different engine operating points, $1250 \mathrm{rpm}$ and 11 bar BMEP, $1500 \mathrm{rpm}$ and 15 bar BMEP, $2000 \mathrm{rpm}$ and 6 bar BMEP, $2500 \mathrm{rpm}$ and 11.7 bar BMEP and, 3000 rpm and 20 bar BMEP. Two different EGR dispersion levels are shown. As before, the EGR dispersion levels are indicated by the regulating valves position next to the speed. The numbers above the bars correspond to the EGR rate in each pipe, so a simple difference between measured and predicted data provides the absolute error in each pipe. The numbers inside the bars corresponding to the predicted results from the model are the relative errors between the predicted and measured values in each pipe. The absolute and the relative error were explained in detail in section 3.3 in Chapter 3. Moreover, in the plot, it is also showed the legend with the non-dimensional RMSE and experimental information concerning the average EGR rate, the symmetry factor and the convexity factor. These parameters were also described in detail in section 3.3. 
The engine running conditions are kept constant in terms of engine speed, torque and average EGR rate but the EGR dispersion regulation valves are operated to have a symmetric and an asymmetric spatial distribution. Because of that, the CF and the SF change at each speed from the top to the bottom plot case.

Figure 4.30 shows two cases at $1250 \mathrm{rpm}$ engine running conditions with two different EGR dispersion levels: 1250_33-33-66 (top) and 1250_25-50-25 (bottom). As it was shown in Figure 4.6, the top case presents a lower EGR standard deviation and the bottom case a higher EGR standard deviation. Moreover, the top case runs with a slightly higher EGR rate to keep NOx constant as it was explained before. Otherwise, both of them show not very high SF, 0.14 and 0.21 respectively that indicates that they are rather symmetric. Furthermore, the top case offers a negative CF of 0.65 , higher than the bottom case, what means that it is a very concavity case unlike the bottom with a negative $C F$ of 0.36 , less concavity. In both cases the model overestimates pipes 2 and 7, and under-predicted pipes 3 and 5. This combination affects to the 4 cylinders independently without any compensation between pipes of the same cylinder. Moreover, top case model offers a spatial pattern of the EGR distribution very flat, it does not predict the concavity trend of the real case. Finally, the ndRMSE is similar for both of them, 30.8\% for the top and 35\% for the bottom, which, despite being a 1D model, it is slightly high as a consequence of the overestimation and the under-prediction of some pipes of different cylinders.

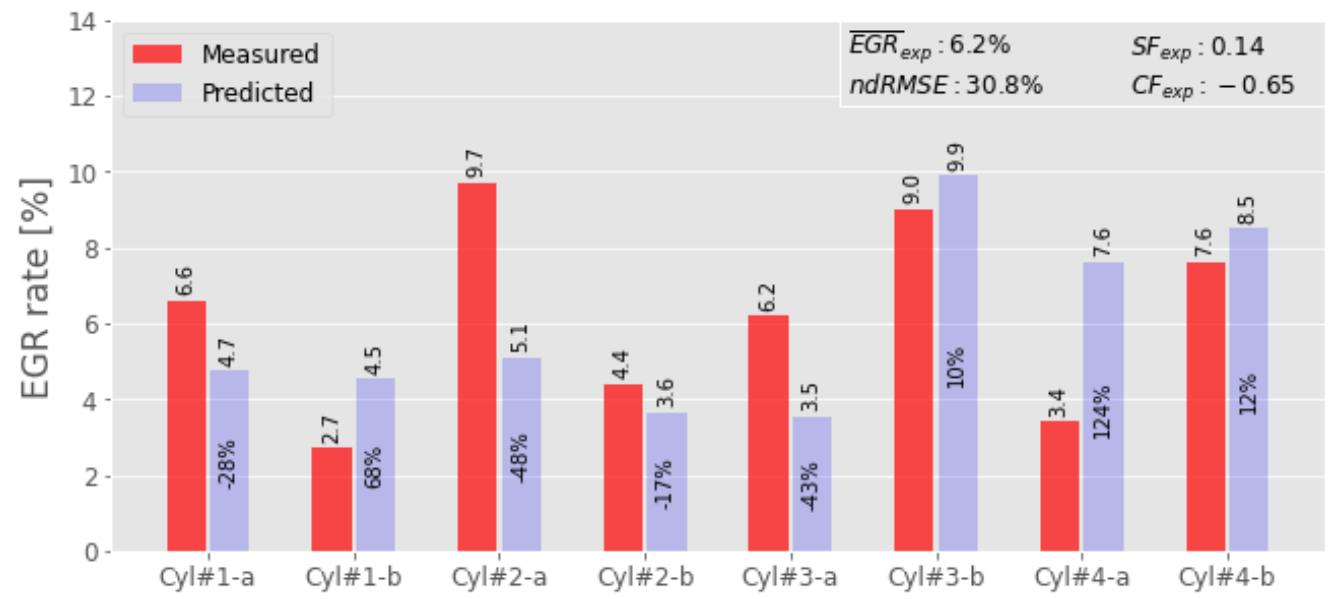




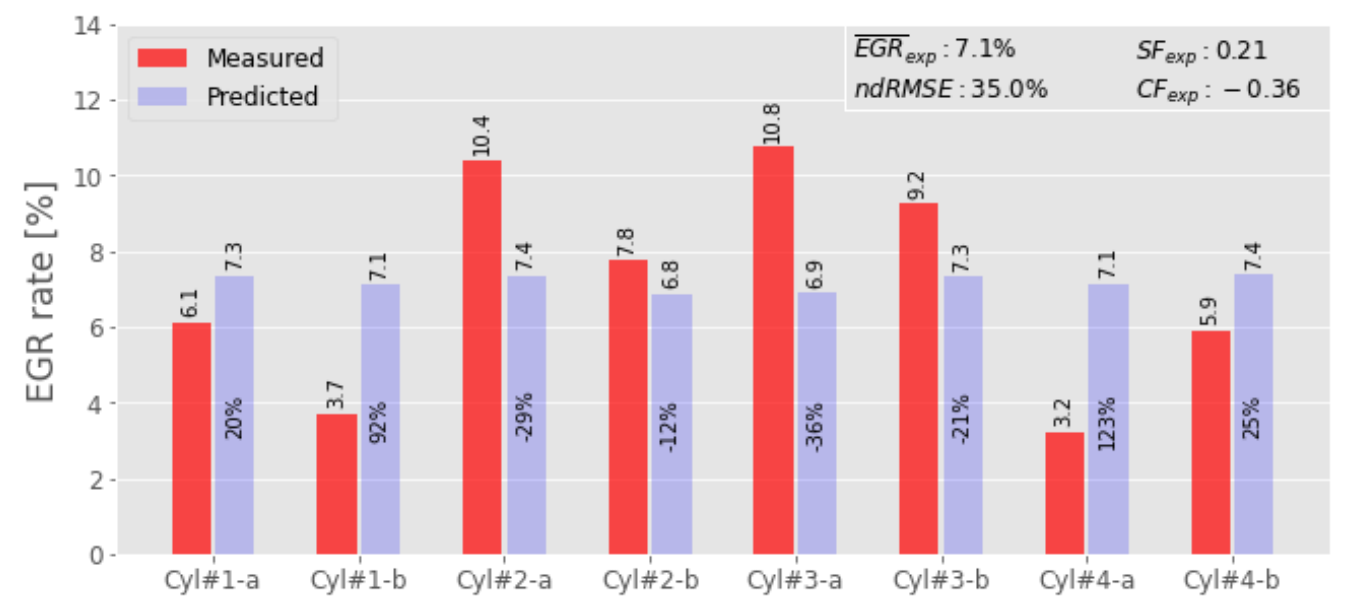

Figure 4.30. Measured and predicted EGR rate in pipes at $1250 \mathrm{rpm}$ and $11 \mathrm{bar}$ BMEP with around 7\% of EGR rate and with two different EGR dispersion levels: 33-33-66 (top) and 25-50-25 (bottom). Y-axis represents the EGR rate and $\mathrm{X}$-axis represents the number of the pipes where the flow circulates.

Figure 4.31 presents two cases at $1500 \mathrm{rpm}$ with two different EGR standard deviation due to the position of the regulation valves to control the EGR dispersion. They are 33-33-66 and 25-75-25 which present low and high EGR standard deviation respectively, as it was shown in Figure 4.6. The top one offers a very high SF that indicates that it is relatively asymmetric and very negative high CF value, which reveals a very concavity case. Moreover, the model under-predicts pipe 3 and overestimates pipe 7, without compensation in pipes of the same cylinders. However, the SF of the bottom case is very close to 0 due to it is a very symmetric case, and the CF is low too, so it is slightly concavity. For this engine running conditions the model prediction for the top case compensates slightly the under-prediction of pipe 1 with overestimation of pipe 2, but it does not compensate the under-prediction of pipe 3 and the overestimation of pipe 7. Consequently, the ndRMSE is better than shown before in Figure 4.30, but not too low. On the other hand, the bottom plot model presents a spatial pattern of the EGR distribution very flat, as in Figure 4.30. The model overestimates the EGR rate in the cylinders of the extremes ( 1 and 4 ) and under-predicts the EGR rate in the cylinders of the center (2 and 3) without cancellation or compensation prediction in pipes of the same cylinder, on the contrary. Consequently, the ndRMSE is higher than the top case, $33.1 \%$. 

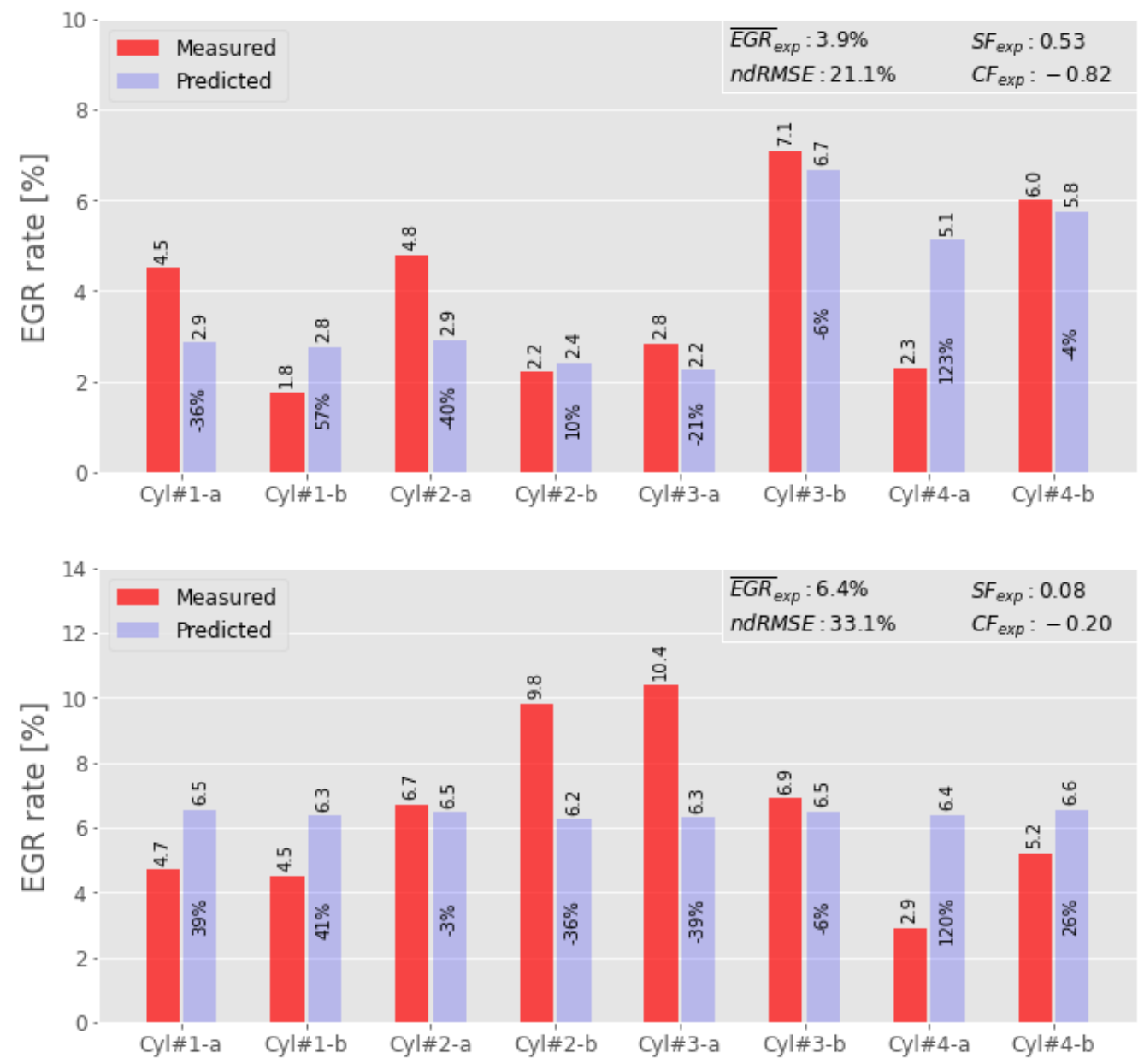

Figure 4.31. Measured and predicted EGR rate in pipes at $1500 \mathrm{rpm}$ and $15 \mathrm{bar}$ BMEP with around 5\% of EGR rate and with two different EGR dispersion levels: 33-33-66 (top) and 25-75-25 (bottom). Y-axis represents the EGR rate and $\mathrm{X}$-axis represents the number of the pipes where the flow circulates.

Figure 4.32 shows the EGR dispersion level at $2000 \mathrm{rpm}$ engine running conditions, 66-25-25 (top) and 25-75-25 (bottom). Moreover, the EGR rate is higher than in the last two figures, around $23 \%$. The top case presents high SF and CF values. It under-predicts the EGR rate in the cylinders 2 and 3 and overestimates the EGR rate in cylinders 1 and 4. The ndRMSE is high. However, top plot offers low SF and CF values and, on the contrary of the last plots with similar situation, the ndRMSE is very low. 

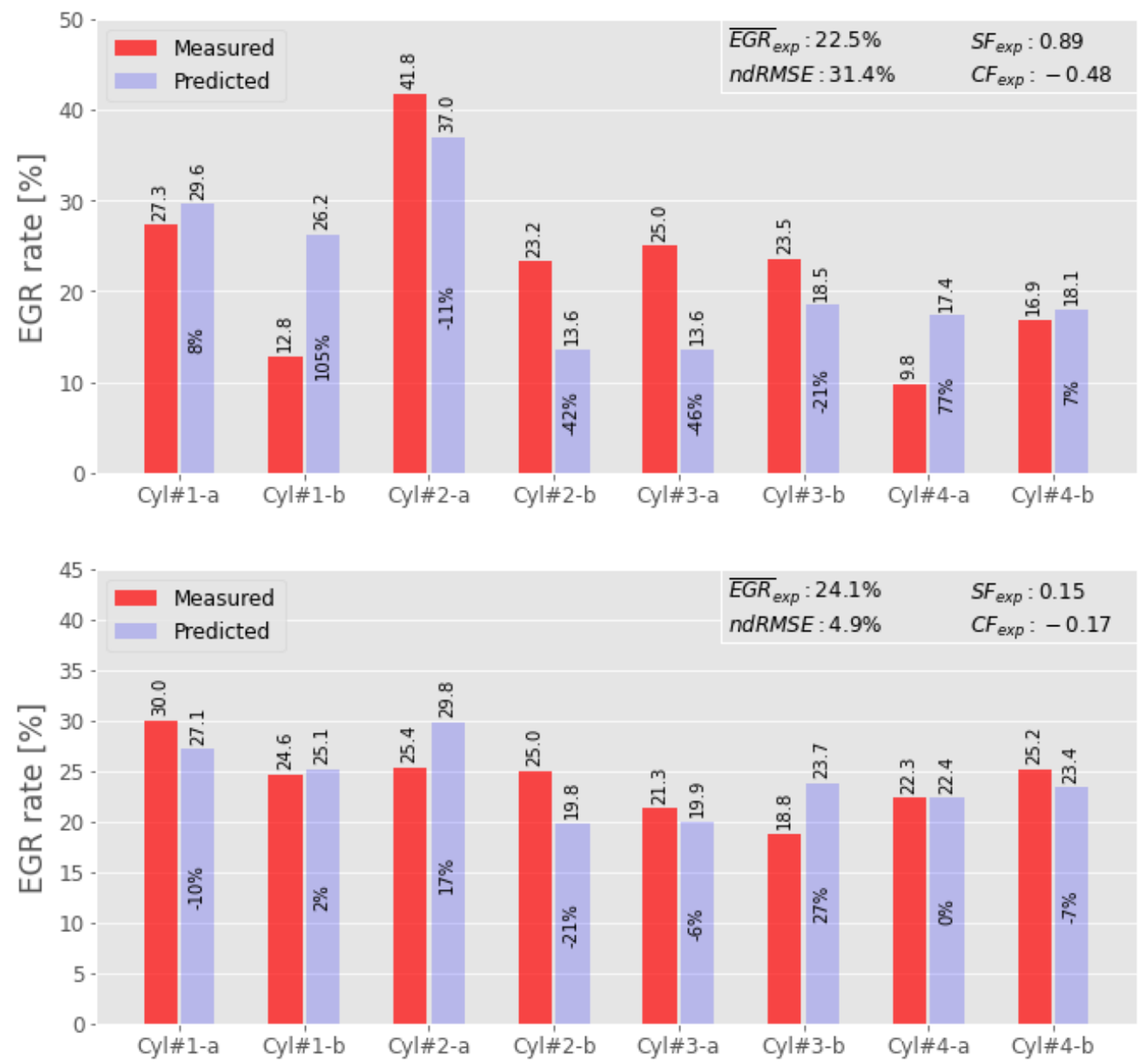

Figure 4.32. Measured and predicted EGR rate in pipes at $2000 \mathrm{rpm} 6$ bar BMEP with around 23\% of EGR rate two different EGR dispersion levels: 66-25-25 (top) and 25-75-25 (bottom). Y-axis represents the EGR rate and X-axis represents the number of the pipes where the flow circulates.

Figure 4.33 exposes two different EGR dispersion level at $2500 \mathrm{rpm}, 25-25-85$ (top) and 50-50-50 (bottom). The top case shows high SF and CF values. It under-predicts the EGR rate in pipes 3, 4 and 5 (cylinders of the center) and overestimates the cylinders of the extrems, especially pipe 7 . Therefore, the ndRMSE is slightly high. On the other hand, the bottom case shows very similar CF value but very low SF. However, it under-predicts pipes 3, 4 and 5 too, and overestimates highly the EGR rate in pipes 2 and 7. Again the model under- 
predicts the EGR distribution in the cylinders of the center and overestimates the cylinder of the extremes. In this case, the ndRMSE is slightly high, too.
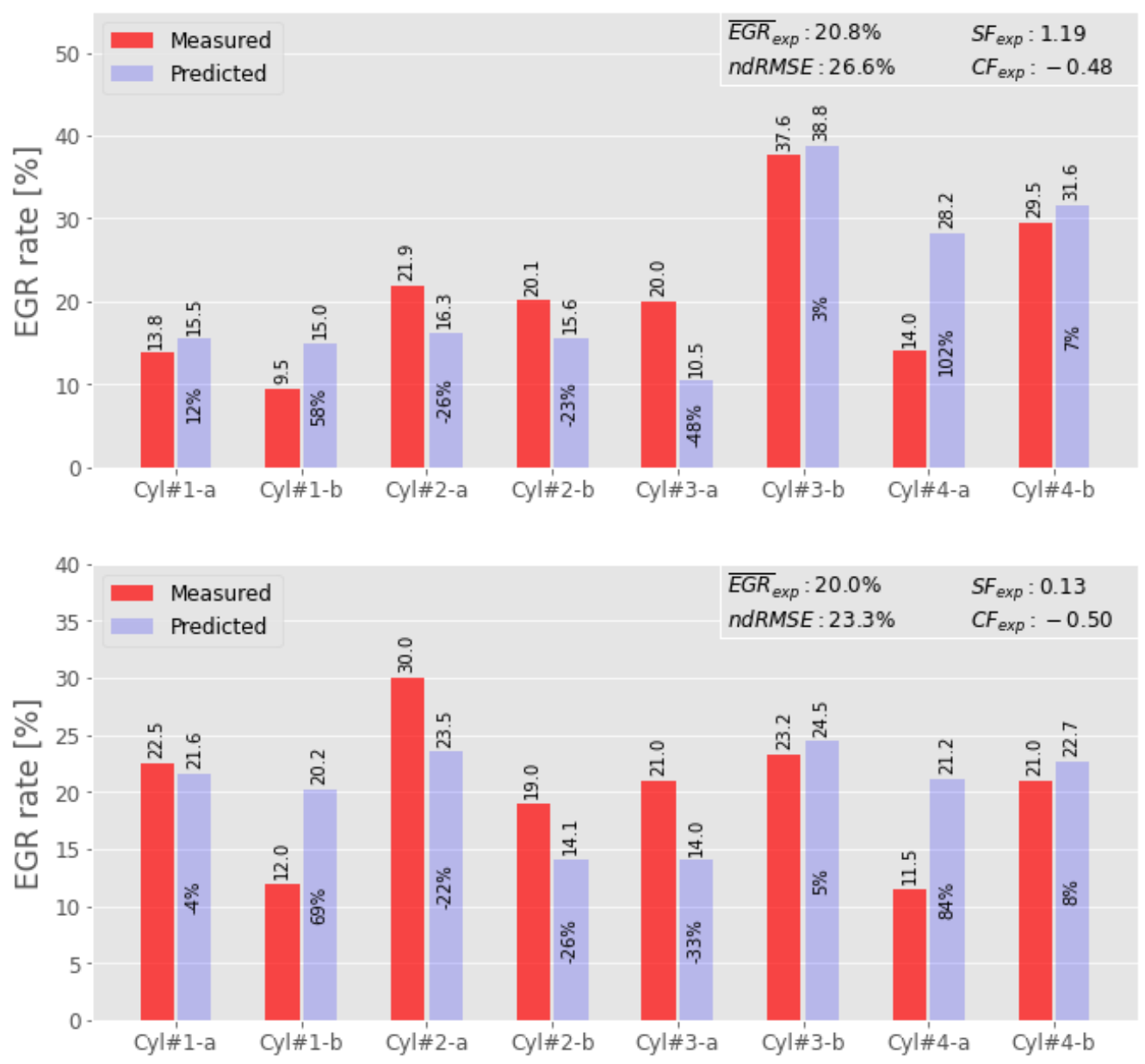

Figure 4.33. Measured and predicted EGR rate in pipes at $2500 \mathrm{rpm}$ and 12 BMEP with $20 \%$ of EGR rate and with two different EGR dispersion levels: $25-$ 25-85 (top) and 50-50-50 (bottom). Y-axis represents the EGR rate and X-axis represents the number of the pipes where the flow circulates.

Finally, Figure 4.34 shows two different EGR dispersion level 15-50-100 (top) and 50-100-50 (bottom) at $3000 \mathrm{rpm}$. The top case offers a very high SF but very low CF. Moreover, the prediction of the EGR distribution among pipes is good and, consequently, the ndRMSE is very low. Furthermore, the bottom case presents very low SF value and low CF value. It under-predicts the EGR rate in 
pipes 3 and 8 but compensates with the overestimation of pipes 4 and 7 . The prediction is good and the ndRMSE is even lower than in the top case.
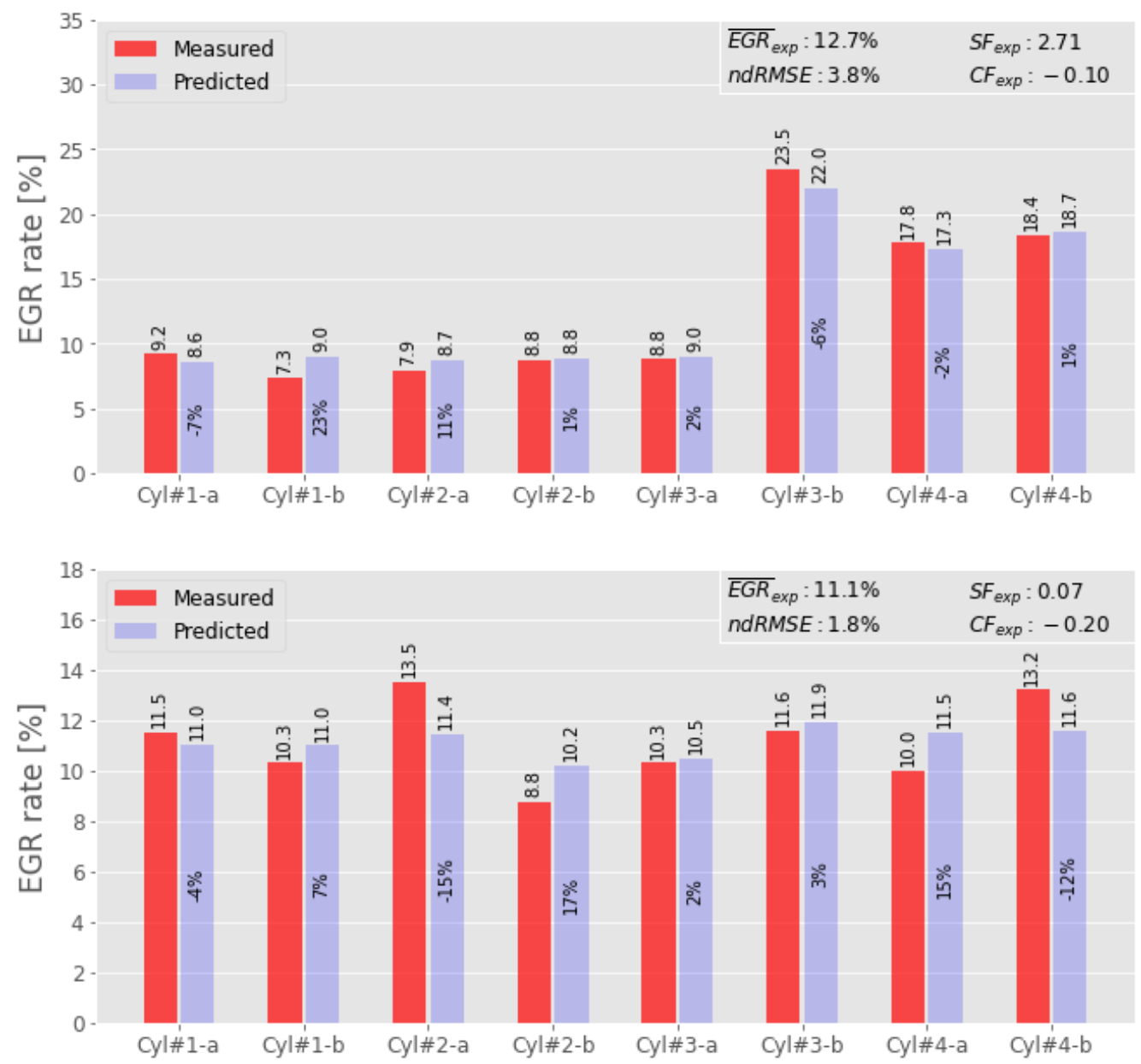

Figure 4.34. Measured and predicted EGR rate in pipes at $3000 \mathrm{rpm}$ and 20 BMEP with around $12 \%$ of EGR rate and two different EGR dispersion levels: 15-50-100 (top) and 50-100-50 (bottom). Y-axis represents the EGR rate and Xaxis represents the number of the pipes where the flow circulates.

Finally, from the last 5 figures, it is observed that the cases with higher ndRMSE independently of the SF and CF values, are the engine running conditions with low speed and low EGR rate (under 10\%). For the rest, if SF, CF or both of them are low, usually the ndRMSE is low too. 


\subsubsection{Model sensitivity to EGR rate variations}

In view of the results of the previous section, where the ndRMSE is worse in cases with low speed and EGR rates independently of the values of CF and SF parameters, in this section, the experimental and modeling results are compared to see the influence of the EGR rate over the COV.

First of all, the effect of the different EGR rates at the same engine running condition is shown. Both, in the experimental test and in the modeling, the air mass flow and the EGR rate change, so the EGR mass flow too. The speed, the torque and the intake pressure keep constant values for every test.

Figure 4.35 presents the comparison at $1500 \mathrm{rpm}$ and 1 bar BMEP with different EGR rates from top to bottom: $42 \%, 29 \%, 22 \%$ and $7 \%$. This is one of the engine running conditions where mixer 1 leads the distribution of the EGR. Mixer 1 goes into the manifold through the orifice in the top of it. It is comparable to an EGR valve regulation distribution of 0-100-0. It provides a low EGR dispersion with $42 \%$ EGR rate and it increases significantly with the lowest EGR rate.

From the experiments, symmetry and convexity factors are close to zero in all the conditions, but the one with the lowest EGR rate, where more EGR is detected in the central pipes. In fact, the convexity factor increases from nearly zero to 0.24 in this case. The model performs with non-dimensional RMSE values lower than $8 \%$ in the three cases with higher EGR rates. With the lowest EGR rate, although the engine model reveals higher EGR levels in the central pipes than in the rest, the phenomenon is not captured as measured in the experiment and the error increases up to $18.7 \%$. So, the ndRMSE is influenced by the EGR rate and the SF and CF values and not by the engine speed. Apparently, the model predicts badly the EGR distribution among pipes at low EGR rates. 

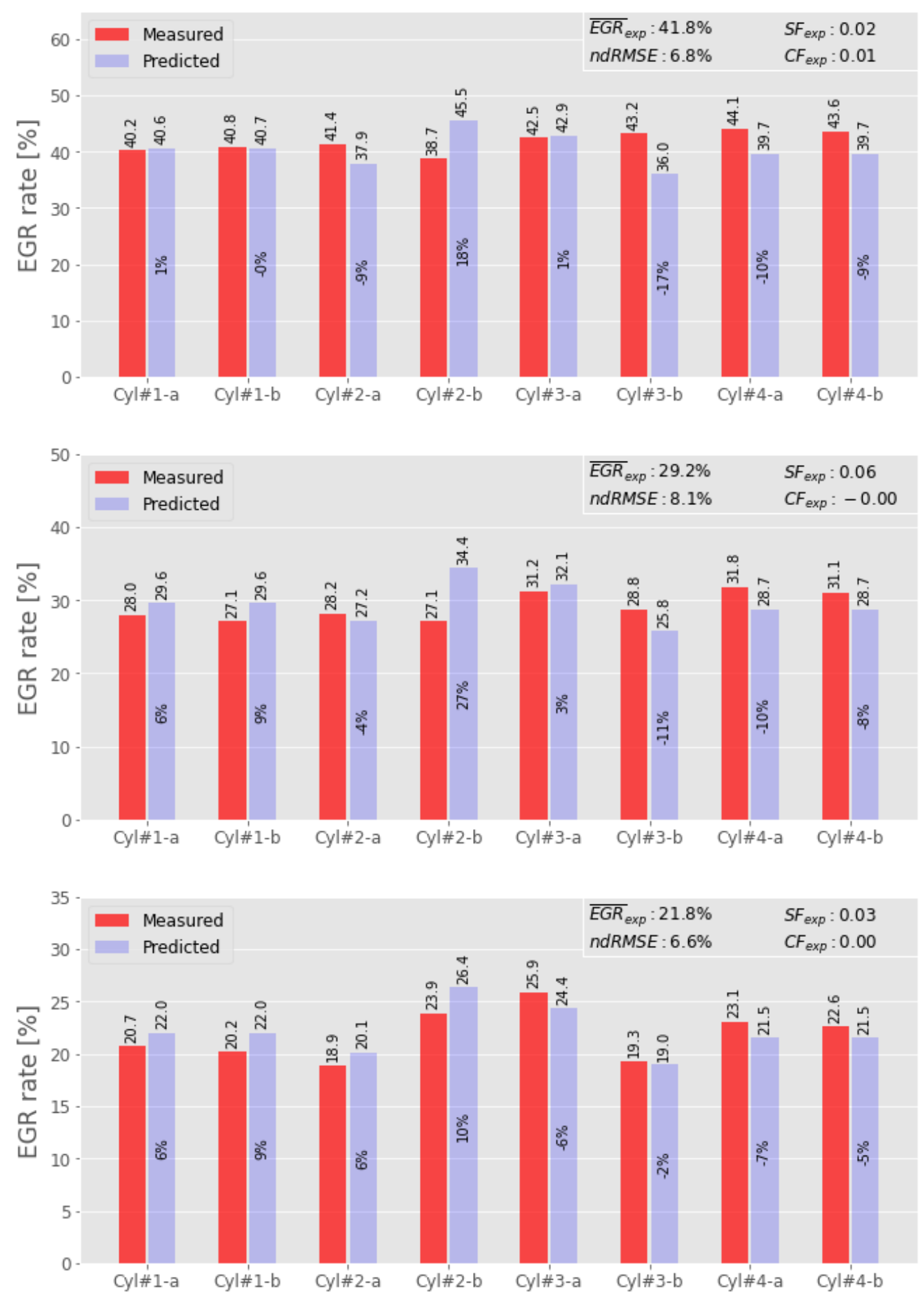


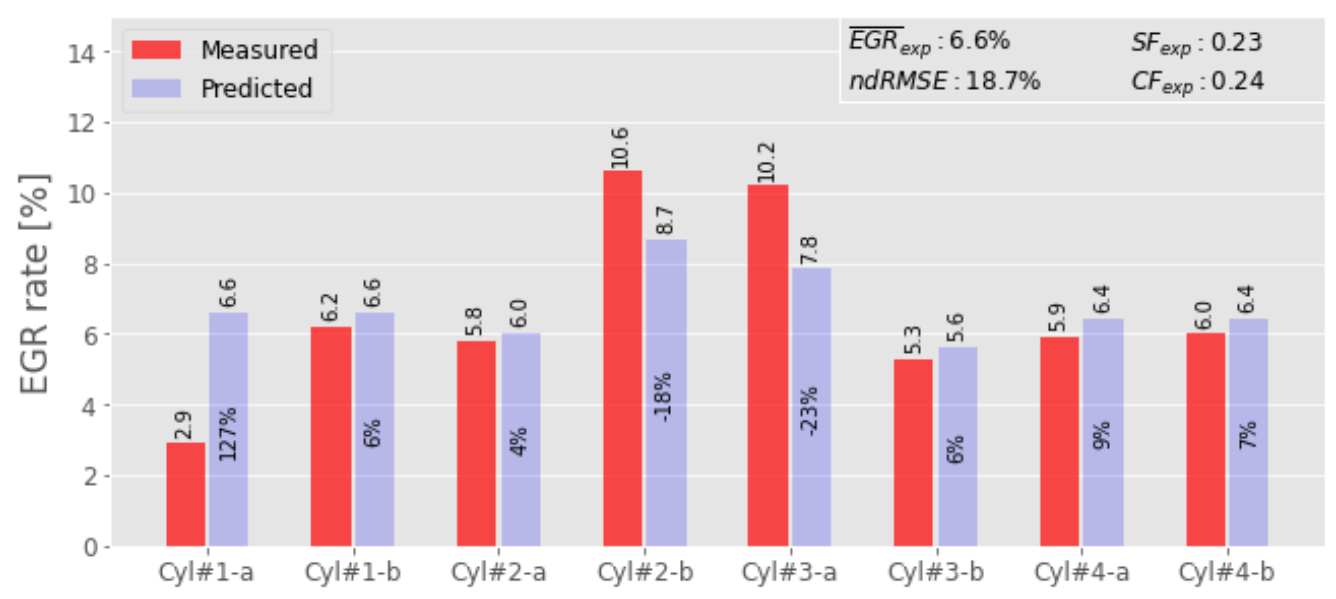

Figure 4.35. Measured and predicted EGR rate in the pipes at $1500 \mathrm{rpm}$ and 1 bar BMEP with $42 \%, 29 \%, 22 \%$ and $7 \%$ EGR rates from top to bottom and symmetric positions for the EGR dispersion valves.

Figure 4.36 shows $1500 \mathrm{rpm}$ and 1 bar of BMEP, $1500 \mathrm{rpm}$ and 3 bar of BMEP, $2000 \mathrm{rpm}$ and 6 bar of BMEP, and $2500 \mathrm{rpm}$ and 10 bar of BMEP. Three of them are the cases of the preliminary study, performed with mixer 1, and the other one was performed with the regulation valves system. The EGR dispersion levels are indicated by the regulating valves position, next to the speed and BMEP.

The $1500 \mathrm{rpm}$ and 1 bar of BMEP running operation point was tested with $42 \%$ of EGR rate, $29 \%, 22 \%$ and $6.5 \%$, as it is shown in the last figure. It is a reduction of $84.5 \%$ from the highest to the lowest EGR rate. It is possible to see how a reduction of $84.5 \%$ of the EGR rate corresponds an increment around of $450 \%$ in the COV, from 0.04 to 0.22 in the experimental results. In the same way, it means an increment of the COV in the modeling results, from 0.02 to 0.05 , an increment of $150 \%$. The COV between experimental and modeling follow the same trend, when the EGR rate increases, the COV decreases. However, the $\mathrm{COV}$ values between the experimental and modeling are more similar at high EGR rates than a low EGR rates. For instance, in the highest EGR rate point, the experimental COV is 0.04 and the modeling COV is 0.02 , while in the lowest EGR rate point, the COV is 0.22 experimentally and 0.05 by modeling. 
At 1500 and 3 bar of BMEP running operation point, the EGR rate decreases from $20 \%$ to $3 \%$ passing through $10.5 \%$. In this case, a reduction of around $85 \%$ of the EGR rate, from $20 \%$ to $3 \%$, implies an increment around $335 \%$ in the COV experimentally, from 0.06 to 0.26 . The COV by modeling increases around $100 \%$, from 0.03 to 0.06 . Once again, the COV is more similar between experimental and modeling when the EGR rate is higher. At $20 \%$ of EGR rate, the COV experimentally is 0.06 and by modeling is 0.03 , while at $3 \%$ of EGR rate, experimentally the COV is 0.26 and by modeling is 0.06 .

The 2000_25-75-25 running condition was tested with 30\%, 24\%, 14\% and 1.5\% of EGR rate. It is a reduction of $95 \%$ from the highest to the lowest EGR rate. The reduction of $95 \%$ of EGR rate represents an increment around $365 \%$ of the COV experimentally, from 0.075 to 0.35 , and an increment of $43 \%$ by modeling, from 0.07 to 0.1 . Again, the trend in the modeling and in the experimental results are the same, a reduction of EGR rate means an increment of COV, although the values are far among them at low EGR rates. At $30 \%$ of EGR rate, the COV is 0.075 experimentally and 0.07 by modeling, and at $1.5 \%$ of EGR rate, is 0.35 and 0.1 respectively.

The 2000_66-25-25 working operation point presents results at $26 \%, 22.5 \%, 15 \%$ and $5 \%$ EGR rate. It means a reduction of $81 \%$ from highest to lowest EGR rate. The reduction from $26 \%$ of EGR to $5 \%$ means an increment around $100 \%$ of the COV experimentally, from 0.3 to 0.6 , and an increment of $38 \%$ of the COV by modeling, from 0.21 to 0.29 . The trend in the modeling and in the experimental results is the same one more time, when the EGR rate decreases, the COV increases. In addition, the COV is more similar with higher EGR rates than with lower, as the previous case. The COV at $26 \%$ of EGR rate is 0.3 experimentally and 0.21 by modeling and, at $5 \%$, is 0.6 and 0.29 respectively.

Finally, in the 2500 and 10 bar of BMEP working operation point, the EGR rate decreases from $17 \%$ to $3 \%$ passing through $7.5 \%$. This reduction around $82 \%$ of the EGR rate means an increment of $150 \%$, from 0.12 to 0.3 , of the COV. Paying attention to the model, the $17 \%$ EGR rate case offers a COV of 0.05 and the 3\% EGR rate case offers a COV of 0.09 , which means an increment of $80 \%$. Therefore, the trend is the same, as before, experimentally and by modeling, when the EGR rate decreases, the COV increases. Nevertheless, the COV is 
more similar at higher EGR rates than lower. At $17 \%$ the COV is 0.12 experimentally and 0.05 by modelling, and, at $3 \%$ the COV is 0.3 experimentally and 0.09 by modeling.

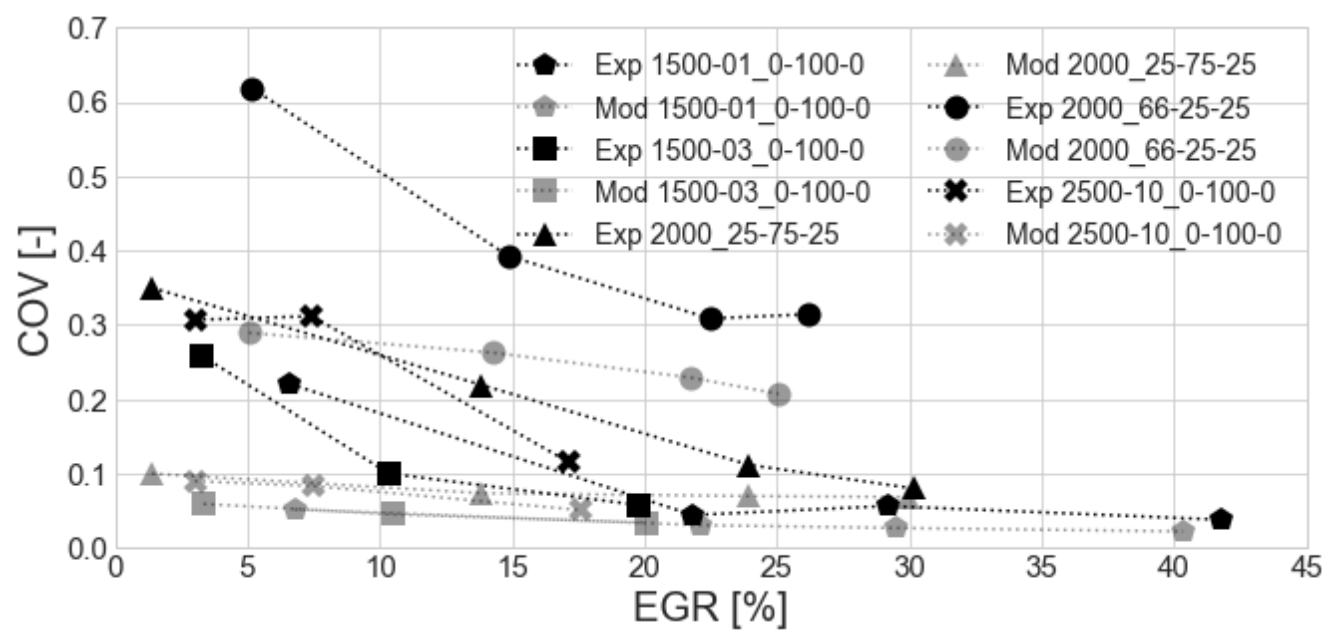

Figure 4.36. 1500-01, 1500-03, 2000_25-75-25, 2000_66-25-25 and 2500-10 running conditions. Each one changes the EGR rate and the EGR dispersion level. Y-axis represents the COV and $\mathrm{X}$-axis represents the EGR rate.

The trend observed before to different EGR rates at the same engine running conditions is observed too independently if the running conditions are the same with different EGR rates or simply different engine running conditions. The $\mathrm{COV}$ is plotted against the averaged EGR rate in Figure 4.37 for 39 engine running conditions, considering the engine running conditions with different EGR rates separately. The results from the engine tests are shown in blue circles, while the model data is given with red crosses. Together with these dots, linear trends are included. An increase in the COV is observed as the EGR rate reduces. This behavior is clearly detected in the engine tests. However, the model is not able to capture this phenomenon, mainly for EGR rates lower than $10 \%$. 


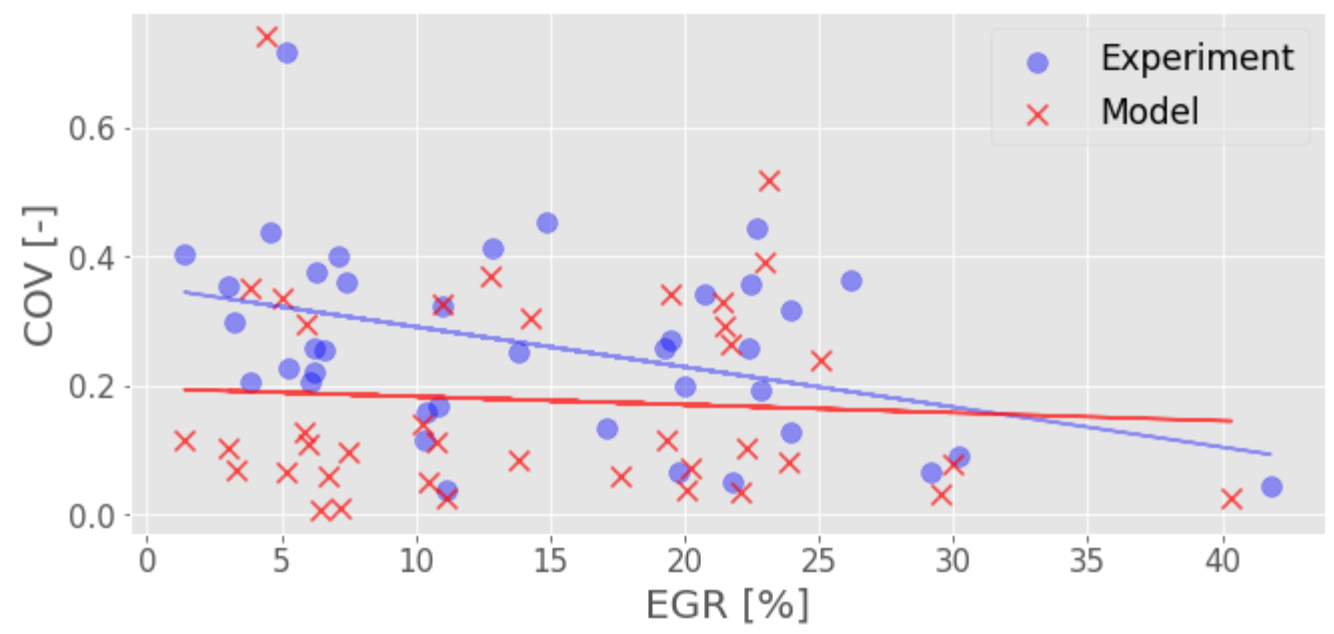

Figure 4.37. Measured and predicted COV as a function of the EGR rate in the 39 engine running conditions.

\subsubsection{D engine model performance}

The absolute and relative errors in the cylinders for the 39 engine running conditions are depicted in Figure 4.38. Each dot and each cross represent a comparison in a cylinder. Blue dots refer to the cylinders at the end of the engine block (either cylinder 1 or 4 ), while red crosses correspond to the cylinders in the central part (either cylinder 2 or 3 ). A positive value means that the model is overestimating the EGR rate in a given cylinder. In general terms, the 1D engine model over-predicts the experimental results concerning the cylinders 1 and 4; the opposite occurs for the other cylinders. The representation of the real intake manifold with 1D and 0D elements allows to have some flow motion from the central part of the manifold to its ends but when cylinders 2 and 3 are in the intake stroke, the flow motion from the pipes of cylinders 1 and 4 is less likely to happen than from the intake line. Therefore, the path for fluid motion between cylinders 1 and 4 to cylinders 2 and 3 is easier in the real 3D geometry rather than in the 0D-1D simple approach. Maximum absolute errors of $10 \%$ in EGR rate take place when the engine operates with EGR rates around $20 \%$. On the other hand, maximum relative errors up to $80 \%$ occur at reduced EGR rates (i. e. lower than $10 \%$ ). 

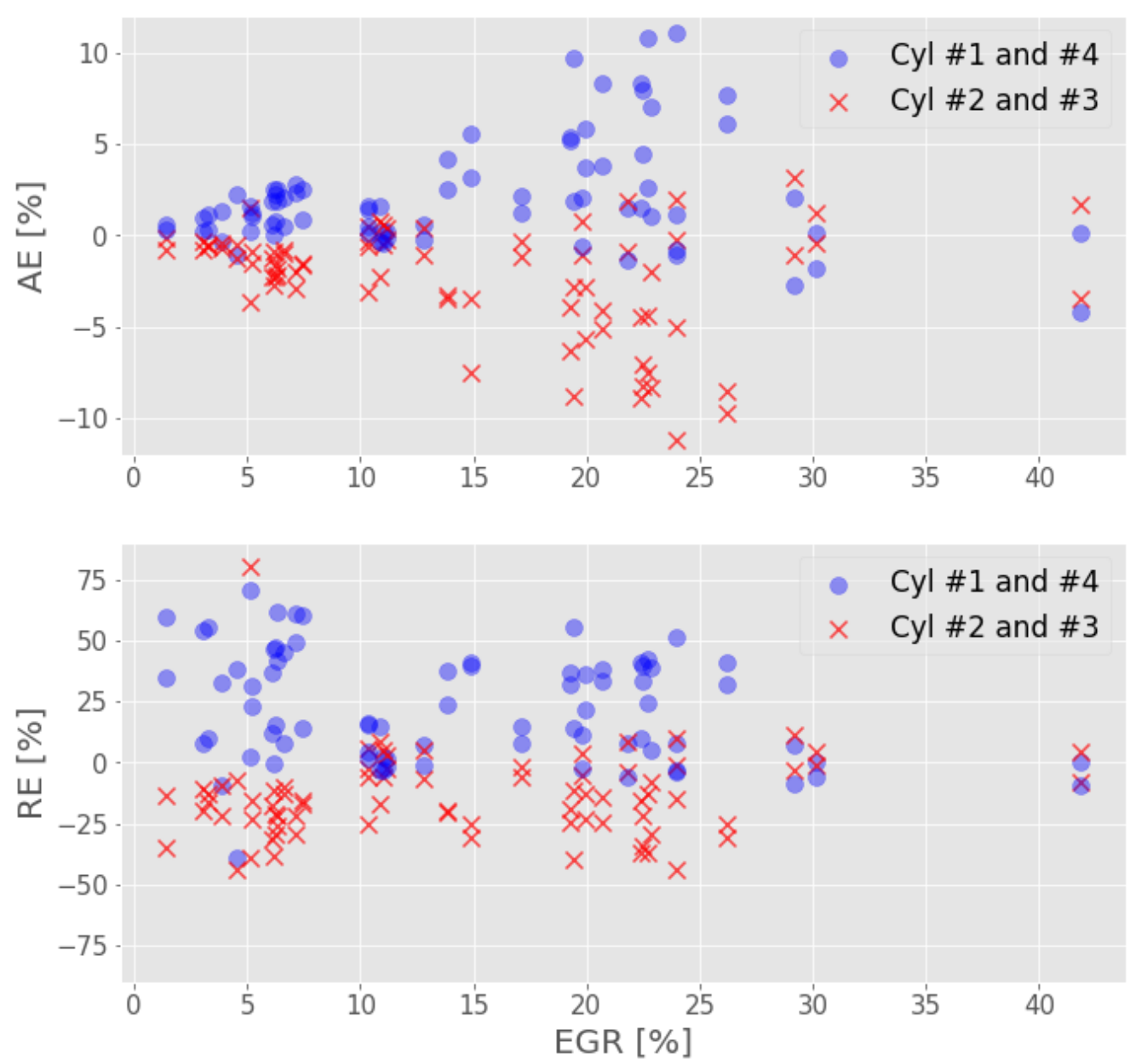

Figure 4.38. Cylinder EGR absolute (top) and relative (bottom) errors as a function of the EGR rate in the 39 engine running conditions (blue dots: cylinders 1 and 4; red crosses: cylinders 2 and 3).

Figure 4.39 correlates the relative errors results with the non-dimensional RMSE. There is an obvious relation between both metrics. Large differences in the model predictions show high values for both the RE and ndRMSE. If the ndRMSE is lower than $10 \%$, the maximum relative errors do not exceed $20 \%$. The same color code for the cylinders is applied in Figure 4.39 than in Figure 4.38. While for ndRMSE values higher than $10 \%$, the model presents a clearly overestimation in the results for cylinders 1 and 4 . This is not so evident for ndRMSE values lower than $10 \%$. 


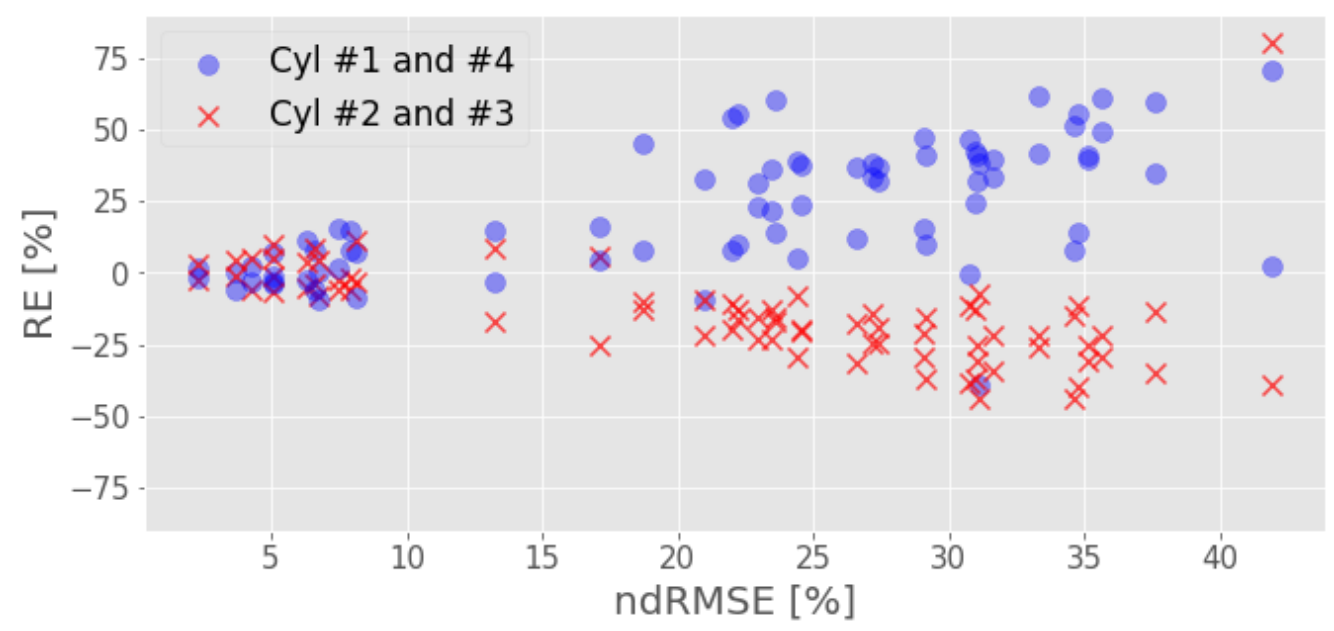

Figure 4.39. Cylinder EGR relative errors as a function of the non-dimensional RMSE in the 39 engine running conditions (blue dots: cylinders 1 and 4; red crosses: cylinders 2 and 3).

A simple inspection of the data presented in Figures 4.38 and 4.39 , with a cloud of dots and crosses ranging from $-50 \%$ to $80 \%$ in relative errors, does not allow to give answers to: (a) the percentage of engine simulations that obtain a specific threshold of relative error, and (b) which engine running conditions the model is able to predict with a good level of agreement. Therefore, a thorough analysis of the results is needed. The top plot in Figure 4.40 shows in the Y-axis the percentage of simulations that achieve a maximum relative error (MRE) found in the X-axis. There are two curves inside: the red one (crosses) corresponds to the analysis when all the simulations are considered, while the blue one (dots) shows the information without considering the engine running conditions with an EGR rate lower than $10 \%$. The plot on the bottom is similar but replacing the $\mathrm{X}$-axis with the non-dimensional RMSE. 

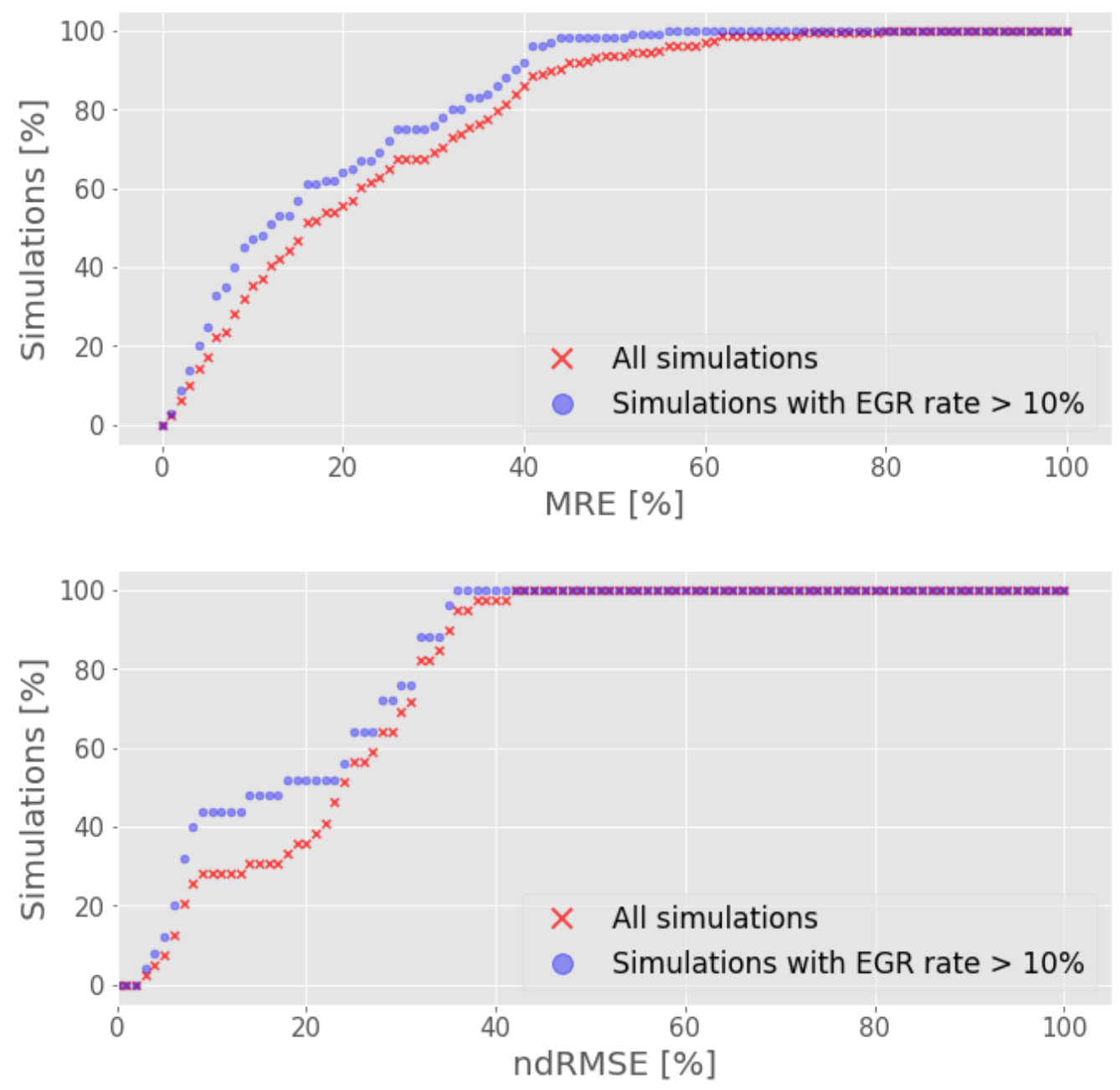

Figure 4.40. Simulations percentage with lower values of maximum RE (top) and non-dimensional RMSE (bottom) with all engine conditions (in red crosses) and engine operation with EGR rate higher than $10 \%$ (in blue dots).

From the data in Figure 4.40 , close to $55 \%$ of all the simulations provide maximum relative errors lower than $20 \%$. If the engine operations with EGR rate lower than $10 \%$ are filtered out, the percentage of simulations increases. For instance, up to $75 \%$ of the simulations provide results with relative errors lower than $25 \%$ and nearly all the simulations run with relative errors lower than $40 \%$. Concerning the non-dimensional RMSE, close to $30 \%$ of all the simulations provide an error lower than $10 \%$, while the percentage of 
simulations increases up close to $45 \%$ if the engine runs with EGR rates higher than $10 \%$.

It is necessary to deepen in the behavior of the model to find out why the model performs so different in terms of cylinder EGR accuracy and, in particular, which engine running conditions have to be met to rely on the data predicted by the 1D. The experimental data for symmetry and convexity factors are plotted against the non-dimensional RMSE in Figure 4.41. It is important to remind that $S F$ takes only positive values, being zero a perfect symmetric spatial EGR dispersion, while CF takes positive and negative values, being zero a completely flat distribution; for visualization purposes, the two Y-axes share the zero value. Engine tests with high convexity factors (in absolute value) and extremely high symmetry factors provide bad model prediction values concerning the non-dimensional RMSE. There are simulations that show high errors with reduced CF and SF but these simulations correspond to low EGR rate engine conditions [2].

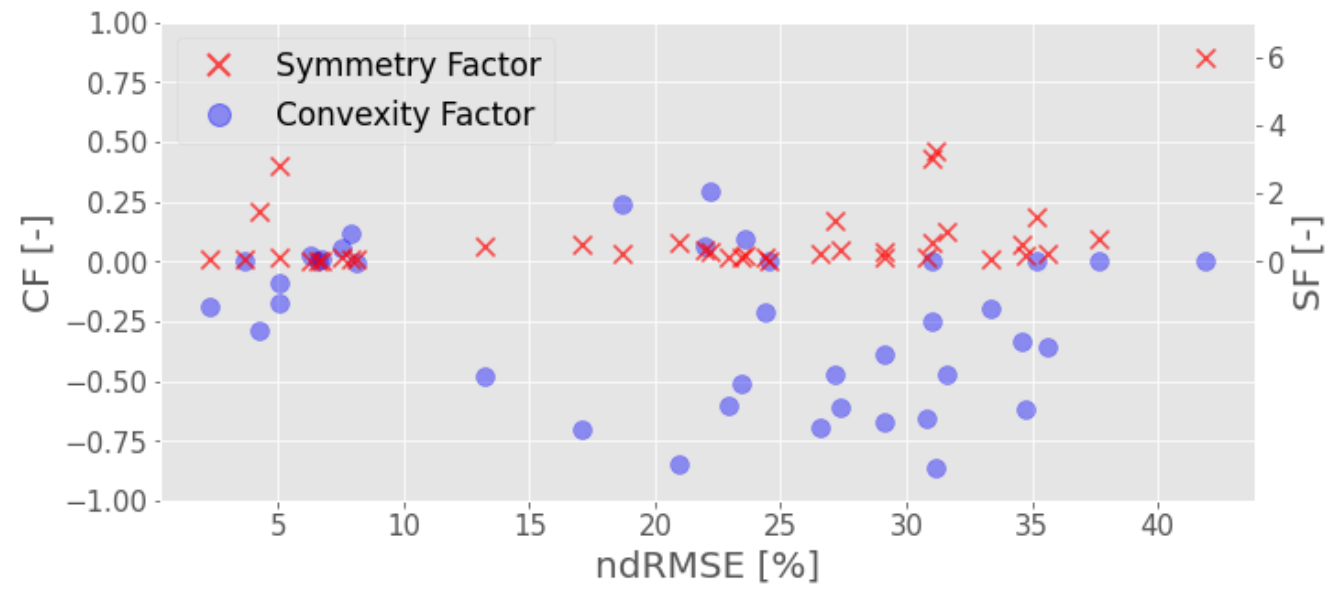

Figure 4.41. Symmetry and convexity factors from the experiments as a function of the non-dimensional RMSE in the 39 engine running conditions.

In the view of the results offered by Figures 4.40 and 4.41, the engine running conditions with a CF value higher than 0.4 are filtered out in Figure 4.42 to represent once again the percentage of simulation against the MRE and the ndRMSE. It is possible to see how the results have improved considerably. Now, a little bit more than $60 \%$ of the simulations provide maximum relative errors lower than $20 \%$. Moreover, if the engine running conditions with EGR 
rate lower than $10 \%$ are filtered out again, the percentage of simulations increases and $80 \%$ of simulations provide results with relative errors lower than $25 \%$, instead of the $75 \%$ of before. In addition, nearly all the simulations run with relative errors lower than $40 \%$. In relation to the non-dimensional RMSE, it was improved considerably. Close to $40 \%$ of all the simulations provide an error lower than 10\%, instead of 30\% commented before. Moreover, the percentage of simulations increases up to $60 \%$ if the engine runs with EGR rates higher than $10 \%$, against $45 \%$ of before.
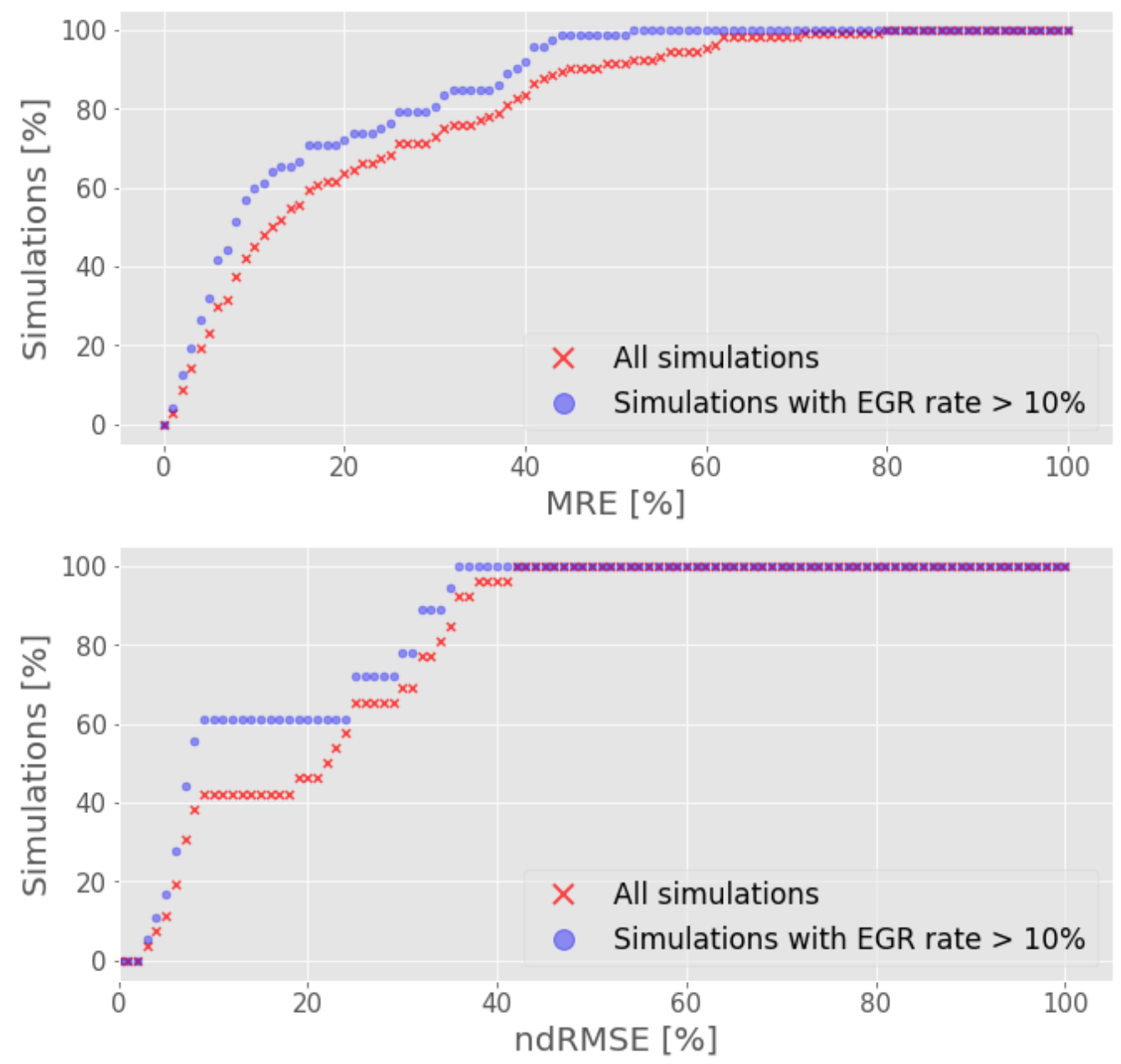

Figure 4.42. Simulations percentage with lower values of maximum RE (top) and non-dimensional RMSE (bottom) with all engine conditions (in red crosses) and engine operation with EGR rate higher than $10 \%$ (in blue dots) to 26 cases with $\mathrm{CF}< \pm 0.4$. 
Furthermore, Figure 4.41 shows that the model works badly with high SF values. So, in Figure 4.43 the engine running conditions with a SF value higher than 0.3 are filtered out. Figure 4.43 represent, once again, the percentage of simulation against the MRE and the ndRMSE. It is possible to see how the results have improved considerably, as in the last figure where the cases with CF values higher than 0.4 were filtered out. Likewise in Figure 4.42, a little bit more than $60 \%$ of the simulations provide maximum relative errors lower than $20 \%$. And if the engine running conditions with EGR rate lower than $10 \%$ are filtered out again, the percentage of simulations increases and $80 \%$ of simulations provide results with relative errors lower than $20 \%$, a bit better than the results in Figure 4.42 and much better than the $60 \%$ of Figure 4.40 which present the 39 simulations. Moreover, the number of simulations with relative errors lower than $40 \%$ increase a little bit. Regarding the non-dimensional RMSE, it presents similar results than Figure 4.42. The percentage of simulations that provides an error lower than $10 \%$ is $40 \%$, instead of $30 \%$ of Figure 4.40 and similar to Figure 4.42. Moreover, the percentage of simulations increases close to $65 \%$ if the engine runs with EGR rates higher than $10 \%$, similar to Figure 4.42 again and better than $45 \%$ of Figure 4.40 .

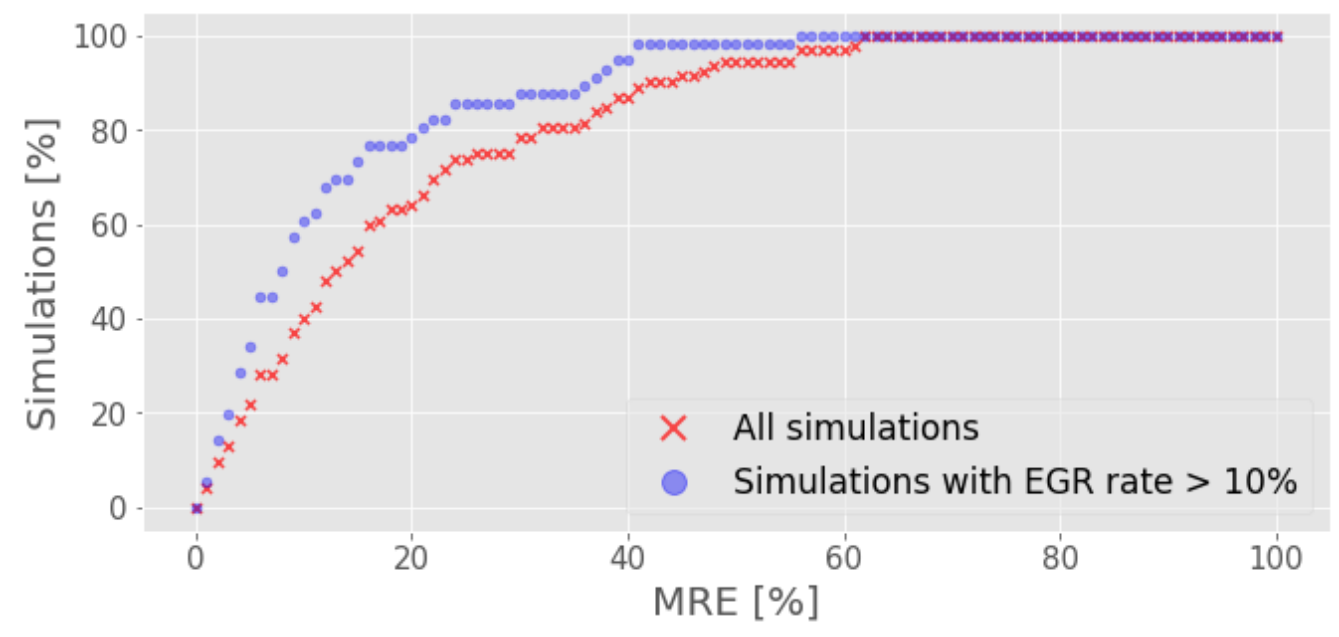




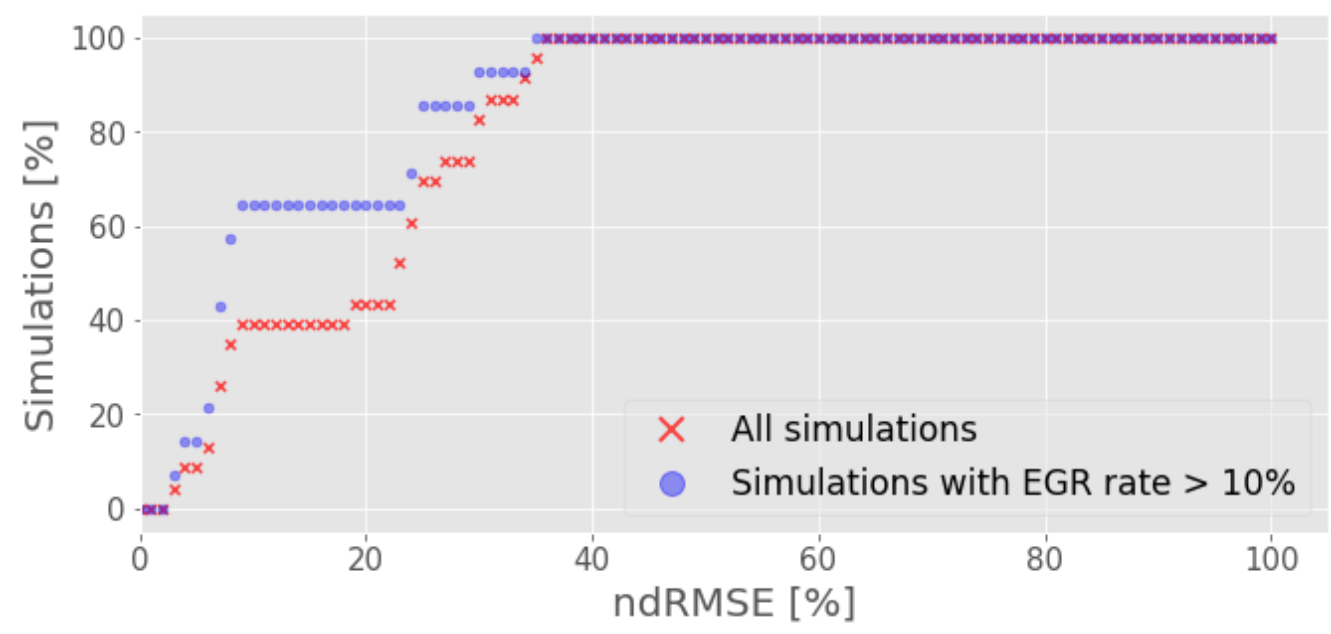

Figure 4.43. Simulations percentage with lower values of maximum RE (top) and non-dimensional RMSE (bottom) with all engine conditions (in red crosses) and engine operation with EGR rate higher than 10\% (in blue dots) to 23 cases with $\mathrm{SF}<0.3$.

Finally, the 17 simulations of the 39 with CF lower than 0.4 and SF lower than 0.3 are presented in Figure 4.44 where the percentage of simulation against the MRE and the ndRMSE is showed by last time. The results are substantially improved. Now, more than $70 \%$ of simulations provide maximum relative errors lower than $20 \%$ against the around of $60 \%$ before. In addition, if it is represented only the engine running conditions with EGR rates higher than 10 $\%$ the percentage of simulations that provide errors lower than $20 \%$ exceed $80 \%$, instead of $60 \%$ of Figure 4.40 . Furthermore, practically all simulations present relative errors lower than $40 \%$. Considering the non-dimensional RMSE, it improves a lot in comparison with the results offered by Figure 4.40 with the 39 simulations. Now, more than $50 \%$ of simulations provides an error lower than $10 \%$, better than $40 \%$ of simulations offered if the SF or CF are filtered out separately and much better than $30 \%$ offered if cases with higher values of $\mathrm{CF}$ and SF are excluded. Finally, the percentage of simulations increases up to $75 \%$ if the engine runs with EGR rates higher than 10\%, against around 60\% showed in Figures 4.42 and 4.43 , and $45 \%$ of Figure 4.40. 

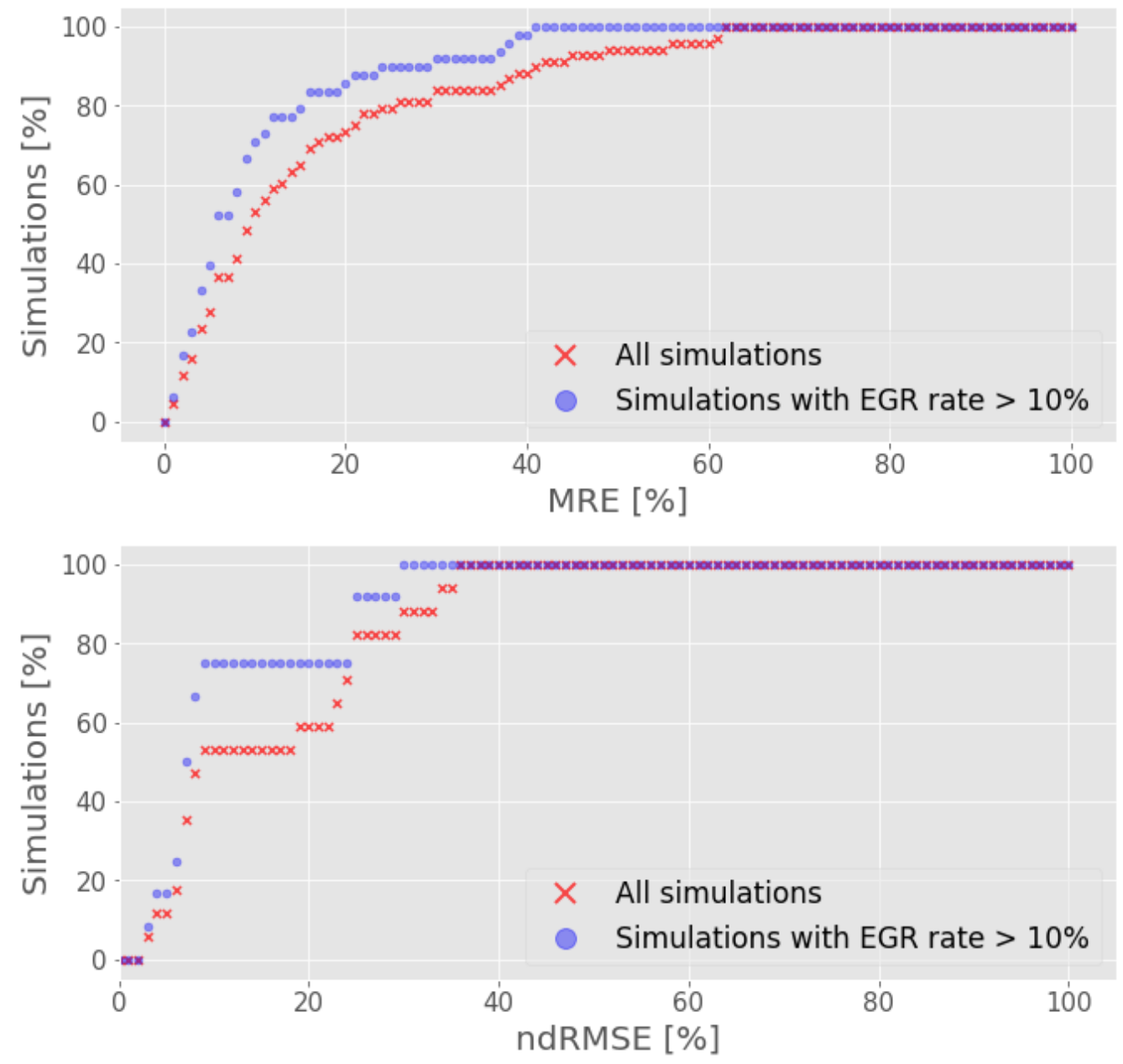

Figure 4.44. Simulations percentage with lower values of maximum RE (top) and non-dimensional RMSE (bottom) with all engine conditions (in red crosses) and engine operation with EGR rate higher than $10 \%$ (in blue dots) to 17 cases with $\mathrm{CF}< \pm 0.4$ and $\mathrm{SF}<0.3$. 


\section{Chapter 4 Bibliography}

[1] V. Macián, J. M. Luján, H. Climent, J. Miguel-García, S. Guilain, and R. Boubennec. "Cylinder-to-cylinder high-pressure exhaust gas recirculation dispersion effect on opacity and NOx emissions in a diesel automotive engine". International Journal of Engine Research (2020). URL: https://doi.org/10.1177/1468087419895401 (cit. on pp. xv, 5, 73, 138, 184).

[2] J. Galindo, H. Climent, R. Navarro, J. Miguel-García, D. Chalet, and P-E. Pretot. "A study on the high pressure EGR transport and application to the dispersion among cylinders in automotive engines". International Journal of Engine Research (2020). URL: https://doi.org/10.1177/1468087420969263 (cit. on pp. xv, 6, 84, 87, 172, 186).

[9] N. Ladommatos, R. Balian, R. Horrocks, and L. Cooper. "The effect of exhaust gas recirculation on soot formation in a high-speed direct-injection diesel engine". Society of Automotive Engineers, SAE paper 960841, 1996 (cit. on pp. 5, 30, 124).

[10] N. Ladommatos, S. M. Abdelhalim, and H. Zhao. "Control of oxides of nitrogen from diesel engines using diluents while minimizing the impact on particulate pollutants". Applied Thermal Engineering 18 (11) (1998), pp. 963980. DOI: https://doi.org/10.1016/S1359-4311(98)00031-3 (cit. on pp. 5, 30, 124).

[11] A. Maiboom, X. Tauzia, and J-F Hétet. “Experimental study of various effects of exhaust gas recirculation (EGR) on combustion and emissions of an automotive direct injection diesel engines". Energy 33 (2008), pp. 22-34. DOI: 10.1016/j.energy.2007.08.010 (cit. on pp. 5, 30, 124).

[12] A. Maiboom, X. Tauzia, S. Shah, and J-F. Hétet. "Experimental Study of an LP EGR System on an Automotive Diesel Engine, compared to HP EGR with respect to PM and NOx Emissions and Specific Fuel Consumption". SAE Int. J. Engines 2(2) (2010), pp. 597-610. URL: https://doi.org/10.4271/2009-24-0138 (cit. on pp. 5,124$)$. 
[13] D. R. Tree and K. I. Svensson. "Soot processes in compression ignition engines". Progress in Energy and Combustion Science 33 (3) (2007), pp. 272-309. URL: https://doi.org/10.1016/j.pecs.2006.03.002 (cit. on pp. 5, 27, 28, 125, 126).

[120] J. William, A. Dupont, R. Bazile, and M. Marchal. "Study of Geometrical Parameter Influence on Air/EGR Mixing". SAE Technical Paper 2003-01-1796, 2003. URL: https://doi.org/10.4271/2003-01-1796 (cit. on p. 101). 
"When we had all the answers, all questions were changed"

Eduardo Galeano

\section{Chapter 5}

Conclusions and future work 



\section{Contents}

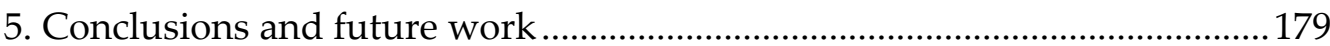

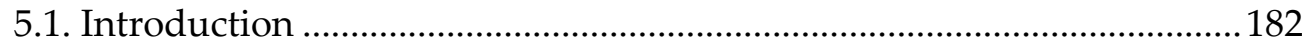

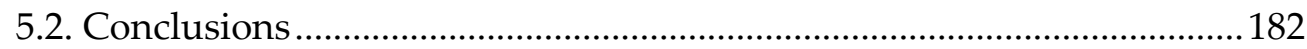

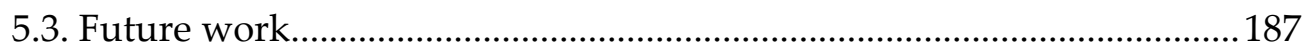

Chapter 5 Bibliography ……......................................................................... 189 


\subsection{Introduction}

This chapter summarizes the results achieved in this study. The current research does not pretend to find and solve all characteristics and issues of the HP EGR dispersion. However, this document is a full analysis of the HP EGR dispersion among cylinders in diesel automotive engines based on previous studies. The present study was developed with some methodology novelties, employing state of the art tools, both, experimental and modeling. Moreover, the study includes a wide set of engine running conditions with different engine speed, engine torque and EGR rate.

First of all, this study provides a detailed analysis about the fuel consumption and emissions consequences of the HP EGR dispersion in diesel engines, including a quantification of the EGR dispersion threshold. Secondly, the study analyzes in depth in the limits of a 1D modeling approach to predict the EGR distribution. The properly conditions which the $1 \mathrm{D}$ modeling is particularly useful to predict the EGR dispersion are filtered and explained.

\subsection{Conclusions}

A novel methodology to study the HP EGR dispersion phenomenon was developed to quantify the impact on engine performance and pollutant emissions. This methodology was based on experimental tests on an automotive diesel engine where the intake manifold was fully instrumented with $\mathrm{CO}_{2}$ probes together with a special hardware to modify and control the EGR dispersion among cylinders. In addition to the conventional emission measurement devices, the tests were performed in four steady engine conditions to carry out a preliminary study with current mixers technology and in five steady engine conditions later in a deep study, including engine running conditions where the EGR strategy was traditionally cancelled. In all of them, the EGR dispersion was modified but keeping constant the intake manifold pressure, the engine torque and the NOx raw emissions. Moreover, on the basis of these engine running conditions, the EGR rate was modified in some of them, keeping constant the intake manifold pressure and the engine torque, but obviously not the NOx emissions. This third round of tests was performed to study the influence of the EGR rate variations over the dispersion and to explore the limitations of the 1D modeling too. 
Concerning the theoretical activities, the limits of the 1D modeling approach have been explored too, employing non-conventional methodologies. The methodology was based on the orientation of the exit holes from the volumes of the intake manifold. The accuracy on this task improve the results according to the EGR dispersion. In this case a specific software was used to import the geometry of the intake manifold from a CAD file to the model.

\section{Experimental conclusions}

In the preliminary study it was observed that the mixer geometry design was able to increase the EGR standard deviation considerably, up to 2 or 3 times. In this way, the definition of the COV parameter was very useful to measure these increments.

The in-cylinder pressure was measured during the experimental campaign. Despite the high values of EGR standard deviation, the IMEP variation range, per cylinders, was lower than $5 \%$ in most of the experimental tests. Exceptionally, it was higher, but the engine average was not affected, so it is possible to say that high modifications in the EGR dispersion did not affect notably to the IMEP of the engine.

Depending on the engine running condition, it was necessary to increase the EGR rate to keep the NOx level constant when the EGR dispersion was varied. This usually happened when the engine run with less than 15\% EGR rate, while according to the results offered by this study, that it was not needed with EGR rates higher than $20 \%$.

Besides the EGR rate, other engine related parameters may influence on the results. A bad distribution between pipes of the same cylinder influences the emissions too. On one hand, a bad distribution between pipes could increase the opacity levels, although the results in that case are not clear and they could be due to other factors like a bad sampling in the runner or a bad mixing of the streamlines inside the cylinders owing to the characteristics of the engine running conditions (low EGR rate and low speed). On the other hand, apparently it could reduce the NOx emissions. However, the EGR dispersion between pipes of the same cylinder and its possible effects are beyond the scope of this research and the conclusions extracted are not solid. In this way, a 
specific study focused in that objective must be performed with the necessary resources. In addition, the lambda value was one of the most important parameters affected by a high EGR standard deviation. If the engine run close to stoichiometric situations, the conditions for remarkable increase of the opacity were likely to occur. Moreover, bad EGR distribution reduced the $\mathrm{O}_{2}$ and increased the CO levels in the exhaust.

Furthermore, it is possible to conclude that the EGR dispersion affects the BSFC. As the bad EGR distribution increased, the BSFC increased especially at high speeds, where the impact on the combustion process was more evident.

Finally, the COV is a non-dimensional coefficient that helped to quantify the effect of the EGR dispersion on opacity emissions. The opacity was also transformed to a non-dimensional value using the opacity value of the test with the least dispersion. Both numbers were plotted together and it was possible to observe that the more affected points are 3000 and $2500 \mathrm{rpm}$ running conditions, without taking into account neither the bad pipes EGR distribution points nor the lowest lambda value case. They were followed by 1500, 1250 and 2000. It indicated that the influence of the lambda value and low EGR rate were not determinant on opacity emissions and the EGR dispersion had an important influence unless it was a very critical case. So, finally, independently of the other factors, there was a clear trend between the opacity and the EGR dispersion among cylinders. Attending to the results, opacity may increases dramatically when the EGR COV exceeds 0.2 [1].

\section{Modeling conclusions}

The performance of a 1D modeling approach to predict the high pressure EGR transport and dispersion in the cylinders of an automotive engine was evaluated in this study. An exhaustive experimental campaign was fulfilled including EGR operation in full load conditions. Up to 39 engine running conditions covering the engine map together with variations in the EGR rate in specific engine speed and engine torque set points were tested. A fast $\mathrm{CO}_{2}$ tracking device was used to assess the 1D model results in 6 locations of the intake manifold. Since the sampling frequency of this equipment provides around 10 measurements per engine cycle, several consecutive engine cycles 
were acquired in order to have a pseudo-evolution of the $\mathrm{CO}_{2}$ with crank-angle resolution.

A 1D engine model was employed to simulate the experiments in the test bench. Instantaneous $\mathrm{CO}_{2}$ concentration predictions in the 6 locations inside the intake manifold led to the following: (a) predictions in locations in the center of the manifold were difficult to capture by the model due to the highly 3D behavior of the flow and the compactness of current intake manifolds; and (b) predictions in the pipes offered better correlations. However, the instantaneous evolutions during the intake stroke of the corresponding cylinder were not always properly captured.

The influence of the new manifold layout, performed with a specific software and based on the CAD manifold file, was compared with a conventional layout based on one big volume and 8 fractioned ducts. The conventional layout offered a flat spatial pattern of the EGR distribution among pipes while the new manifold layout presented more similar EGR distribution among pipes.

The influence of the wave dynamics over the EGR distribution was studied too in the 1D model. Three different lengths of the EGR line were tested in the model to perform the analysis. In the first moment, an EGR mass flow gap appeared in the EGR line among the three different simulations, but it did not in the intake line or in the manifold. The gap disappeared according the flow advanced along the EGR line up to the EGR mass flow of the different simulations overlapped among themselves. Finally, the differences observed, in the EGR distribution among cylinders, among the three simulations were lower than $2 \%$. The gap observed was due to the EGR flow is leaded by the exhaust pulses when it is closer of the exhaust in the EGR line, but it is commanded by the intake pulses when it is closer of the intake. It is possible to conclude that the wave dynamics does not affect to the EGR distribution among cylinders.

Faced with the possibility that the volumes that composed the manifold model slow down the flow, a study of the influence of the manifold size was performed with the conventional manifold layout comparing the original size with a smaller volume. The original volume was reduced by 100 times. Although the amplitude of the air and EGR mass fraction waves changed, the periodicity did 
not. Moreover, the differences of the EGR distribution pipe to pipe at three different engine running conditions were lower than $5 \%$. Therefore, it is possible to conclude that the volumes that composed partially the intake manifold did not interfere in the EGR distribution in the model.

Comparisons in EGR averaged values in the pipes were also discussed to assess the performance of the 1D model. Globally, the model underestimated the EGR rates in the central cylinders (2 and 3), while an overestimation occurred in the cylinders at the engine block ends ( 1 and 4 ). From the experimental perspective, the normalized EGR standard deviation increased with low EGR rates. This phenomenon was not captured by the model, which shown maximum relative errors in some cylinders around $60 \%$. The prediction in terms of in-cylinder EGR improved to differences lower than $40 \%$ if the engine operating points with an average EGR rate lower than $10 \%$ were excluded. In this situation, the $75 \%$ of the predicted in-cylinder EGR rates had differences lower than $25 \%$ when compared to experiments.

From a predictive point of view, the figures shown by the 1D model were not remarkable, at least for all simulations. There was an obvious correlation between the individual errors in the cylinders and the global metric to evaluate the prediction performance, which was the ndRMSE. It presented values up to $40 \%$ [2]. Moreover, only close of 30\% simulations provided ndRMSE lower than $10 \%$, linked to relative errors in the cylinders lower than $20 \%$.

Besides the lower EGR rates, high CF and SF values promoted a bad prediction of the EGR distribution by the model. If CF values higher than \pm 0.4 and SF values higher than 0.3 were filtered, more than $70 \%$ of simulation provided maximum relative errors lower than $20 \%$, up to $80 \%$ if the EGR rates lower than $10 \%$ were excluded. In addition, more than $50 \%$ of simulation provided a ndRMSE lower than $10 \%$, up to $75 \%$ if the EGR rates lower than $10 \%$ were excluded.

The simulations with ndRMSE higher than $10 \%$ were trying to reproduce experimental profiles for the EGR spatial distribution with remarkable values of the convexity factor or symmetry factor. Therefore, the model provided best results when reproducing engine situations with high EGR rates and an HP- 
EGR system that enabled a moderate EGR dispersion, being both conditions typically found in current automotive engines.

\subsection{Future work}

This work introduces some novelties: First of all, the manufacturing device with three regulation valves to control different levels of HP EGR dispersion. While previous studies employed some different manifolds [14] or mixers [15, 106, 109], but without the precision and the variety EGR dispersion levels that the system used in the current study provides. Moreover, a $\mathrm{CO}_{2}$ fast tracking system is used too. Finally, a 1D modeling that take into account the orientation of the ducts thanks to a convertor from CAD file to 1D model is employed. It improves the precision of a simple 1D layout and does not count with the high computational cost of the 3D modeling [73, 102]. However, some questions were left due to lack of time or resources. Next suggestions must be taken into account to future studies about the EGR dispersion effects:

- One of the conclusions extracted from the results of the study is the increment of BSFC according to the EGR standard deviation increase. However, it is not known why this happens, and why especially at high speeds. It is necessary to do a more thorough analysis to find its causes.

- The EGR is a strategy commonly used in diesel engines for a long time to reduce NOx emissions. Nevertheless, the last years this technique was incorporate to gasoline engines too, in order to reduce fuel consumption and NOx emissions too [121]. Some research that includes, for instance, the comparison between HP and LP EGR has been done [61], but there is a lack in the literature about the HP EGR dispersion in gasoline engines and its effects over combustion and emissions.

- Finally, in this study it has been evidenced that the 1D modeling is not capable to predict the EGR distribution among cylinders to low EGR rates, under $10 \%$. The reasons are not obvious. There is a room of improvement in the 1D modeling development in this way. 



\section{Chapter 5 Bibliography}

[1] V. Macián, J. M. Luján, H. Climent, J. Miguel-García, S. Guilain, and R. Boubennec. "Cylinder-to-cylinder high-pressure exhaust gas recirculation dispersion effect on opacity and NOx emissions in a diesel automotive engine". International Journal of Engine Research (2020). URL: https://doi.org/10.1177/1468087419895401 (cit. on pp. xv, 5, 73, 138, 184).

[2] J. Galindo, H. Climent, R. Navarro, J. Miguel-García, D. Chalet, and P-E. Pretot. "A study on the high pressure EGR transport and application to the dispersion among cylinders in automotive engines". International Journal of Engine Research (2020). URL: https://doi.org/10.1177/1468087420969263 (cit. on pp. xv, 6, 84, 87, 172, 186).

[14] R. M. Siewert, R. B. Krieger, M. S. Huebler, P. C. Baruah, B. Khalighi, and M. Wesslau. "Modifying and Intake Manifold to Improve Cylinder-to-Cylinder EGR Distribution in a DI Diesel Engine Using Combined CFD and Engine Experiments". 2001 SAE Technical Paper 2001-01-3685. URL: http://dx.doi.org/10.4271/2001-01-3685 (cit. on pp. 5, 40, 67, 187).

[15] A. Maiboom, X. Tauzia, and J-F. Hétet. "Influence of EGR unequal distribution from cylinder to cylinder on NOx-PM trade-off of a HSDI automotive Diesel engine". Applied Thermal Engineering 29 (2009), pp. 20432050. DOI: 10.1016/j.applthermaleng.2008.10.017 (cit. on pp. 5, 40, 67, 187).

[61] K. Shen, F. Li, Z. Zhang, Y. Sun, and C. Yin. "Effects of LP and HP cooled EGR on performance and emissions in turbocharged GDI engine". Applied Thermal Engineering 125 (2017), pp. 746-755. URL: https://doi.org/10.1016/j.applthermaleng.2017.07.064 (cit. on pp. 31, 187).

[73] M. Hernández. "A non-linear quasi-3D model for air management modelling in engines". Doctoral Thesis (2018) (cit. on pp. 34, 35, 36, 37, 38, 39, $40,78,187)$.

[102] A. J. Torregrosa, A. Broatch, F. J. Arnau, and M. Hernández. “A non-linear quasi-3D model with Flux-Corrected-Transport for engine gas-exchange 
modelling". Journal of Computational and Applied Mathematics 291 (2016), pp. 103-111. DOI: 10.1016/j.cam.2015.03.034 (cit. on pp. 39, 78, 187).

[106] W. P. Partridge, S. A. Lewis, M. J. Ruth, G. G. Muntean, R. C. Smith, and J. H. Stang. "Resolving EGR Distribuion and Mixing". 2002, SAE Technical Paper 2002-01-2882. URL: http://dx.doi.org/10.4271/2002-01-2882 (cit. on pp. 40, $67,187)$.

[109] J. M. Luján, H. Climent, B. Pla, M. E. Rivas-Perea, N-Y. François, J. BorgesAlejo, and Z. Soukeur. "Exhaust gas recirculation dispersion analysis using incylinder pressure measurements in automotive diesel engines". Applied Thermal Engineering 89 (2015), pp. 459-468. URL: https://doi.org/10.1016/j.applthermaleng.2015.06.029 (cit. on pp. 41, 67, 187).

[121] H. Wei, T. Zhu, G. Shu, L. Tan, and Y. Wang. “Gasoline engine exhaust gas recirculation - A review". Applied Energy 99 (2012), pp. 534-544. URL: https://doi.org/10.1016/j.apenergy.2012.05.011 (cit. on p. 187). 
"Utopia is on the horizon. If I walk two steps towards it, it draws away two steps further, and the horizon runs ten steps beyond. So, how does Utopia works? Precisely for that, it is used to walk towards somewhere."

Fernando Birri 



\section{Bibliography}

Agarwal, D., Kumar Singh, S. K., and Agarwal, A. K. «Effect of Exhaust Gas Recirculation (EGR) on performance, emissions, deposits, and durability of a constant speed compression ignition engine.» Applied Energy 88 (2011), pp. 2900-2907

(cit. on p. 29)

Bai, S., Han, J., Liu, M., Qin, S., Wang, G., and Li, G-x. «Experimental investigation of exhaust thermal management on NOx emissions of heavy-duty diesel engine under the world Harmonized transient cycle (WHTC).» Applied Thermal Engineering 142 (2018), pp. 421-432. URL: https://doi.org/10.1016/j.applthermaleng.2018.07.042 ～(cit. on p. 29)

Benson, R. S. Thermodynamics and Gas Dynamics of Internal Combustion Engines. Cambridge University Press, 1982

(cit. on p. 35)

Benson, R. "The Effect of Excess Scavenge Air on the Pressure Drop in the Cylinder of a Two-Stroke Cycle Engine During Exhaust Blow down.» The Aeronautical Journal 59(539) (1955), pp. 773-778

(cit. on p. 35)

Benson, R., and Woods, W. «Wave action in the exhaust system of a supercharged two-stroke-engine model.» International Journal of Mechanical Sciences 1(2-3) (1960), pp. 253-281 (cit. on p. 35)

Bermúdez, V., Serrano, J. R., Piqueras, P., Gómez, J., and Bender, S. «Analysis of the role of altitude on diesel engine performance and emissions using an atmosphere simulator.» International Journal of Engine Research 18(12) (2017), pp. 105-117. DOI: 10.1177/1468087416679569 (cit. on p. 32)

Bird, R. B., Lightfoot, E. N., and Stewart, W. E. Transport phenomena. New York/Toronto: Wiley, 2007

(cit. on p. 81)

Book, D. L., Boris, J. P., and Hain, K. «Flux-corrected transport II: Generalizations of the method.» Journal of Computational Physics 18(3) (1975), pp. 248-283. URL: https://doi.org/10.1016/0021-9991(75)90002-9

(cit. on p. 39) 
Boris, J. P., and Book, D. L. «Flux-corrected transport. I. SHASTA, a fluid transport algorithm that works.» Journal of Computational Physics 11(1) (1973), pp. 38-69. URL: https://doi.org/10.1016/0021-9991(73)90147-2

(cit. on p. 39)

Campbell, I. M., and Thrush, B. A. «Reactivity of hydrogen to atomic nitrogen and atomic oxygen.» Transactions of the Faraday Society 64 (1968), pp. 1265-1274. URL: https://doi.org/10.1039/TF9686401265 (cit. on p. 26)

Chalet, D., Lesage, M., Cormerais, M., and Marimbordes, T. «Nodal modelling for advanced thermal-management of internal combustion engine.» Applied Energy 190 (2017), pp. 99-113. DOI: 10.1016/j.apenergy.2016.12.104 (cit. on p. 84)

Climent, H. «Contribución al modelado unidimensional de motores de dos tiempos de pequeña cilindrada.» Doctoral Thesis. 2002

(cit. on pp. 34, 35, 36)

Colebrook, C. F. «Turbulent Flow in Pipes, with Particular Reference to the Transition Region between the Smooth and Rough Pipe Laws.» Journal of the Institution of Civil Engineers 11 (1939), pp. 133-156 (cit. on p. 81)

Conticini, E., Frediani, B., and Caro, D. «Can atmospheric pollution be considered a co-factor in extremely high level of SARS-CoV-2 lethality in Northern Italy?» Environmental Pollution (2020). DOI: 10.1016/j.envpol.2020.114465

(cit. on p. 25)

Courant, R., Isaacson, E., and Rees, M. «On the solution of nonlinear hyperbolic differential equations by finite differences.» Communications on Pure and Applied Mathematics 5(3) (1952), pp. 243-255 (cit. on p. 36)

Dimitrou, P., Burke, R., Copeland, C., and Akehurst, S. «Study on the Effects of EGR Supply Configuration on Cylinder-to-Cylinder Dispersion and Engine Performance Using 1D-3D Co-Simulation.» SAE Int. (2015)

(cit. on p. 40)

Dwyer, H., Allen, R., Ward, M., Karnopp, D., and Margolis, D. «Shock capturing finite difference methods for unsteady gas transfer.» 7 th Fluid and PlasmaDynamics Conference. (1974), p. 521

(cit. on p. 35) 
Environmental Protection Agency. «EPA Sets New National Air Pollution Standard for Lead.» $1978 . \quad$ URL: https://archive.epa.gov/epa/aboutepa/epa-sets-new-national-airpollution-standard-lead.html (cit. on p. 18)

European Environment Agency. «Air quality in Europe - 2015 Report.» EEA Report No 5/2015. (2015). ISBN 978-92-9213-702-1, ISSN 1977-8449. DOI: $10.2800 / 62459$

(cit. on p. 4)

European Environment Agency. «Air quality in Europe - 2016 Report.» EEA Report No 28/2016. (2016). ISBN 978-92-9213-847-9, ISSN 1977-8449. DOI: $10.2800 / 80982$ (cit. on p. 23)

European Environment Agency. "Air quality in Europe - 2017 Report.» EEA Report No 13/2017. (2017). ISBN 978-92-9213-921-6, ISSN 1977-8449. DOI: $10.2800 / 850018$

(cit. on p. 23)

European Environment Agency. "Air quality in Europe - 2018 Report.» EEA Report No 12/2018. (2018). ISBN 978-92-9213-989-6, ISSN 1977-8449. DOI: $10.2800 / 777411$

(cit. on p. 23)

European Environment Agency. «Air quality in Europe - 2019 Report.» EEA Report No 10/2019. (2019). ISBN 978-92-9480-088-6, ISSN 1977-8449. DOI: $10.2800 / 822355$

(cit. on p. 23)

Fenimore, C. P. «Formation of nitric oxide in premixed hydrocarbon flames.» Symposium (International) on Combustion 13(1) (1971), pp. 373-380. URL: https://doi.org/10.1016/S0082-0784(71)80040-1 (cit. on p. 26)

Galindo, J., and Hernández, J. J. «Modelado de motores.» Motores de combustión interna alternativos. Ed. Universitat Politècnica de València: F. Payri and J.M. Desantes, 2011, pp. 745-797

(cit. on pp. 34, 39)

Galindo, J., Climent, H., Navarro, R., García-Olivas, G., Guilain, S., and Boubennec, R. «Effect of Numerical Configuration on Predicted EGR Cylinder-to-Cylinder Dispersion.» SAE Technical Paper 2020-01-1113 (2020). DOI: $10.4271 / 2020-01-1113$

(cit. on pp. 86, 87) 
Galindo, J., Climent, H., Navarro, R., Miguel-García, J., Chalet, D., and Pretot, P-E. «A study on the high pressure EGR transport and application to the dispersion among cylinders in automotive engines.» International Journal of Engine Research (2020). URL:https://doi.org/10.1177/1468087420969263 (cit. on pp. xv, 6, 84, 87, 172, 186)

Galindo, J., Climent, H., Varnier, O., and Patil, C. «Effect of boosting system architecture and thermomechanical limits on diesel engine performance: Part II-transient operation.» International Journal of Engine Research 19(8) (2017), pp. 873-885. DOI:10.1177/1468087417732264

(cit. on p. 33)

Galindo, J., Piqueras, P., Navarro, R., Tarí, D., and Meano, C. M. «Validation and sensitivity analysis of an in-flow water condensation model for 3DCFD simulations of humid air streams mixing.» International Journal of Thermal Sciences 136 (2019), pp. 410-419. DOI: 10.1016/j.ijthermalsci.2018.10.043

(cit. on p. 32)

Galindo, J., Serrano, J. R., Arnau, F. J., and Piqueras, P. «Description of a SemiIndependent Time Discretization Methodology for a One-Dimensional Gas Dynamics Model.» ASME. J. Eng. Gas Turbines Power 131(3) (2009). URL: https://doi.org/10.1115/1.2983015 (cit. on p. 74)

Glassman, I. Combustion. San Diego: Academic Press, $1996 \quad$ (cit. on p. 28)

Godunov, S. K. "A difference method for numerical calculation of discontinuous solutions of the equations of hydrodynamics.» Matematicheskii Sbornik 89(3) (1959), pp. 271-306 （cit. on pp. 36, 38)

Guan, B., Zan, R., Lin, H., and Huang, Z. «Review of state of the art technologies catalytic reduction of NOx from diesel engine exhaust.» Applied Thermal Engineering 66(1-2) (2014), pp. 395-414. URL: https://doi.org/10.1016/j.applthermaleng.2014.02.021 (cit. on p. 29)

Harten, A., Lax, P. D., and van Leer, B. «On upstream differencing and Godunov-type schemes for hyperbolic conservation laws.» SIAM review 25(1) (1983), pp. 35-61

(cit. on p. 38) 
Haynes, B. S., and Wagner, H. Gg. «Soot formation.» Progress in Energy and Combustion Science 7(4) (1981), pp. 229-273. URL: https://doi.org/10.1016/0360-1285(81)90001-0 (cit. on p. 27)

Henein, N. A. «Analysis of pollutant formation and control and fuel economy in diesel engines.» Progress in Energy and Combustion Science 1(4) (1976), pp. 165-207. URL: https://doi.org/10.1016/0360-1285(76)90013-7

(cit. on p. 4)

Hernández, M. «A non-linear quasi-3D model for air management modelling in engines.» Doctoral Thesis. 2018

(cit. on pp. 34, 35, 36, 37, 38, 39, 40, 78, 187)

Hurn, R. W. "Air pollution and the compression-ignition engine.» Symposium (International) on Combustion 12(1) (1969), pp. 677-687. URL: https://doi.org/10.1016/S0082-0784(69)80449-2 ） (cit. on p. 4)

Jenny, E. «Unidimensional transient flow with consideration of friction, heat transfer and change of section.» Brown Boveri Review 37(11) (1950), pp. $447-461$

(cit. on p. 35)

Kaprielian, L. «Modélisation OD pour la combustion dans les moteurs à allumage commandé : développements en proche paroi et dans le front de flamme.» PhD Thesis. Arts et Métiers Paris Tech, 2015 (cit. on p. 80)

Kehoe, R. A. «Contaminated and Natural Lead Environments of Man.» Archives of Environmental Health: An International Journal 11(5) (1965), pp. 736-739. URL: https://doi.org/10.1080/00039896.1965.10664290 （cit. on p. 18)

Ladommatos, N., Abdelhalim, S. M., and Zhao, H. «Control of oxides of nitrogen from diesel engines using diluents while minimizing the impact on particulate pollutants.» Applied Thermal Engineering 18(11) (1998), pp. 963-980. URL: https://doi.org/10.1016/S1359-4311(98)00031-3

(cit. on pp. 5, 30, 124)

Ladommatos, N., Abdelhalim, S. M., and Zhao, H. «The effects of exhaust gas recirculation on diesel combustion and emissions.» International Journal of Engine Research 1(1) (2000), pp. 107-126. URL: https://doi.org/10.1243/1468087001545290 (cit. on p. 30) 
Ladommatos, N., Abdelhalim, S. M., Zhao, H., and Hu, Z. «The dilution, chemical, and thermal effects of exhaust gas recirculation on diesel engine emissions - Part 1: Effect of reducing inlet charge oxygen.»SAE paper 961165 (1996)

(cit. on p. 30)

Ladommatos, N., Abdelhalim, S. M., Zhao, H., and Hu, Z. «The dilution, chemical, and thermal effects of exhaust gas recirculation on diesel engine emissions - Part 2: Effects of carbon dioxide.» SAE paper 961167 (1996)

(cit. on p. 30)

Ladommatos, N., Abdelhalim, S. M., Zhao, H., and Hu, Z. «The dilution, chemical, and thermal effects of exhaust gas recirculation on diesel engine emissions - Part 3: Effects of water vapor.» SAE paper 971659 (1997) (cit. on p. 30)

Ladommatos, N., Abdelhalim, S. M., Zhao, H., and Hu, Z. «The dilution, chemical, and thermal effects of exhaust gas recirculation on diesel engine emissions - Part 4: Effects of carbon dioxide and water vapor.» SAE paper 971660 (1997)

(cit. on p. 30)

Ladommatos, N., Balian, R., Horrocks, R., and Cooper, L. "The effect of exhaust gas recirculation on combustion and NOx emissions in a highspeed direct-injection diesel engine.» Society of Automotive Engineers, SAE paper 960840 (1996)

(cit. on pp. 5, 30)

Ladommatos, N., Balian, R., Horrocks, R., and Cooper, L. «The effect of exhaust gas recirculation on soot formation in a high-speed directinjection diesel engine.» Society of Automotive Engineers, SAE paper 960841 (1996)

(cit. on pp. 5, 30, 124)

Lakhlani, H., Barman, J., Rajput, K., and Goswami, A. «Experimental Study of EGR Mixture Design and its Influence on EGR Distribution Across the Cylinder for NOx-PM Tradeoff.» SAE Int. (2013). DOI: 10.4271/2013-012743

(cit. on pp. 5, 40)

Lapuerta, M., and Ballesteros, R. «Emisiones contaminantes.» Motores de combustión interna alternativos. Ed. F. Payri and J.M.Desantes. Universitat Politècnica de València, 2011, pp. 415-444.

(cit. on pp. 27, 28) 
Lapuerta, M., Ramos, Á., Fernández-Rodríguez, D., and González-García, I. «High-pressure versus low-pressure exhaust gas recirculation in a Euro 6 diesel engine with lean-NOx trap: Effectiveness to reduce NOx emissions.» International Journal of Engine Research 20(1) (2018), pp. 155163. URL: https://doi.org/10.1177/1468087418817447 （cit. on p. 32)

Lavoie, G. A., Heywood, J. B., and Keck, J. C. «Experimental and Theoretical Study of Nitric Oxide Formation in Internal Combustion Engines.» Combustion Science and Technology 1(4) (1970), pp. 313-326. DOI: 10.1080/00102206908952211

(cit. on p. 26)

Lax, P., and Wendroff, B. «Systems of conservation laws.» Communications on Pure and Applied mathematics 13(2) (1960), pp. 217-237

(cit. on p. 35)

Lerat, A., and Peyret, R. «Non-centred schemes and shock propagation problems.» Computers and fluids (1974), pp. 35-52

(cit. on p. 36)

Lerat, A., and Peyret, R. «The problem of spurious oscillations in the numerical solution of the equations of gas dynamics.» Proceedings of the Fourth International Conference on Numerical Methods in Fluid Dynamics. Berlin/Heidelberg: Springer, 1975, pp. 251-256 (cit. on p. 36)

Luján, J. M., Climent, H., Aranu, F., and Miguel-García, J. «Analysis of low pressure exhaust gases recirculation control in transient operation of automotive diesel engines.» Applied Thermal Engineering 137 (2018), pp. 184-192. URL: https://doi.org/10.1016/j.applthermaleng.2018.03.085

(cit. on pp. xvii, 33, 59)

Luján, J. M., Climent, H., García-Cuevas, L. M., and Moratal, A. «Volumetric efficiency modelling of internal combustion engines based on a novel adaptative learning algorithm of artificial neural networks.» Applied Thermal Engineering 123 (2017), pp. 625-634. URL: https://doi.org/10.1016/j.applthermaleng.2017.05.087 (cit. on p. 73)

Luján, J. M., Climent, H., Pla, B., Rivas-Perea, M. E., François, N-Y., BorgesAlejo, J., and Soukeur, Z. «Exhaust gas recirculation dispersion analysis using in-cylinder pressure measurements in automotive diesel 
engines.» Applied Thermal Engineering 89 (2015), pp. 459-468. URL: https://doi.org/10.1016/j.applthermaleng.2015.06.029

(cit. on pp. $41,67,187$ )

Luján, J. M., Climent, H., Ruiz, S., and Moratal, A. «Influence of ambient temperature on diesel engine raw pollutants and fuel consumption in different driving cycles.» International Journal of Engine Research 20(8-9) (2019), pp. 877-888. DOI: 10.1177/1468087418792353

(cit. on p. 33)

Luján, J. M., Dolz, V., Monsalve-Serrano, J., and Bernal Maldonado, M. A. «High-pressure exhaust gas recirculation line condensation model of an internal combustion diesel engine operating at cold conditions.» International Journal of Engine Research (2019). URL: https://doi.org/10.1177/1468087419868026 (cit. on p. 32)

Luján, J. M., Dolz, V., Monsalve-Serrano, J., and López-Cascant, J. A. «New anti-pollution regulation for Euro 6 diesel vehicles.» Técnica Industrial 318 (2017), pp. 28-33. DOI:10.23800/9939

(cit. on p. 33)

Luján, J. M., Guardiola, C., Pla, B., and Reig, A. «Switching strategy between HP (high pressure) - and LPEGR (low pressure exhaust gas recirculation) systems for reduced fuel consumption and emissions.» Energy 90 (2015), pp. 1790-1798. DOI: 10.1016/j.energy.2015.06.138

(cit. on p. 32)

MacCormack, R. W. «Numerical solution of the interaction of a shock wave with a laminar boundary layer.» Proceedings of the Second International Conference on Numerical Methods in Fluid Dynamics, Lecture Notes in Physics. Berlin/Heidelberg: Springer, 1971, pp. 151-163. URL: https://doi.org/10.1007/3-540-05407-3_24 (cit. on p. 36)

MacCormack, R. W. «The effect of viscosity in hypervelocity impact cratering.» Frontiers of Computational Fluid Dynamics (1969), pp. 27-44 (cit. on p. 36)

Macián, V., Luján, J. M., Climent, H., Miguel-García, J., Guilain, S., and Boubennec, R. «Cylinder to cylnder high-pressure exhaust gas recirculation dispersion effect on opacity and NOx emissions in a diesel 
automotive engine.» International Journal of Engine Research (2020). URL: https://doi.org/10.1177/1468087419895401 (cit. on pp.xv, 5, 73, 138, 184)

Maiboom, A., and Tauzia, $\mathbf{X}$. «NOx and PM emissions reduction on an automotive HSDI Diesel engine with water-in-diesel emulsion and EGR: An experimental study.» Fuel 90(11) (2011), pp. 3179-3192. URL: https://doi.org/10.1016/j.fuel.2011.06.014 (cit. on pp. 30, 31)

Maiboom, A., Tauzia, X., and Hétet, J-F. «Experimental study of various effects of exhaust gas recirculation (EGR) on combustion and emissions of an automotive direct injection diesel engines.» Energy 33 (2008), pp. 22-34. DOI: 10.1016/j.energy.2007.08.010

(cit. on pp. 5, 30, 124)

Maiboom, A., Tauzia, X., and Hétet, J-F. «Influence of EGR unequal distribution from cylinder to cylinder on NOx-PM trade-off of a HSDI automotive Diesel engine.» Applied Thermal Engineering 29 (2009), pp. 2043-2050. DOI: 10.1016/j.applthermaleng.2008.10.017

(cit. on pp. $5,40,67,187$ )

Maiboom, A., Tauzia, X., and Hétet, J-F. «Influence of high rates of supplemental cooled EGR on NOx and PM emissions of an automotive HSDI diesel engine using an LP EGR loop.» International Journal of Engine Research 32(15) (2008), pp. 1383-1398. DOI: 10.1002/er.1455

(cit. on p. 30)

Maiboom, A., Tauzia, X., Shah, S., and Hétet, J-F. «Experimental Study of an LP EGR System on an Automotive Diesel Engine, compared to HP EGR with respect to PM and NOx Emissions and Specific Fuel Consumption.» SAE Int. J. Engines 2(2) (2010), pp. 597-610. URL: https://doi.org/10.4271/2009-24-0138

(cit. on pp. 5, 124)

Manabe, S., and Wetherlad, R. T. «Thermal Equilibrium of the Atmosphere with a Given Distribution of Relative Humidity.» Journal of the Atmospheric Science 24(3) (1967)

(cit. on p. 4)

Millo, F., Giacominetto, P. F., and Bernardi, M. G. «Analysis of different exhaust gas recirculation architetures for passenger car Diesel engines.» 
Applied Energy 98 (2012), pp. 79-91. URL: https://doi.org/10.1016/j.apenergy.2012.02.081 (cit. on p. 31)

Montenegro, G., Della Torre, A., Onorati, A., Fairbrother, R., and Dolinar, A. «Development and application of 3D generic cells to the acoustic modelling of exhaust systems.» SAE Technical Paper 2011-01-1526 (2011)

(cit. on p. 39)

Montenegro, G., Onorati, A., and Della Torre, A. «The prediction of silencer acoustical performances by 1D, 1D-3D and quasi-3D non-linear approaches.» Computers \& Fluids 71 (2013), pp. 208-223. DOI: 10.1016/j.compfluid.2012.10.016

(cit. on p. 39)

Moratal, A. «Experimental analysis of thermal management influence on performance and emissions in diesel engines at low ambient temperature.» Doctoral Thesis. 2018

(cit. on p. 26)

Morel, T., Silvestri, J., Goerg, K-A., and Jebasinski, R. «Modeling of engine exhaust acoustics.» SAE Technical Paper 1999-01-1665 (1999) (cit. on p. 40)

Needleman, H. L. «Clair Patterson and Robert Kehoe: Two Views of Lead Toxicity.» Environmental Research 78(2) (1998), pp. 79-85. URL: https://doi.org/10.1006/enrs.1997.3807

(cit. on p. 18)

Newell, R. G., and Rogers, K. «The U.S. Experience with the Phasedown of Lead in Gasoline.» Resources for the Future (2003)

(cit. on p. 19)

Nichols, A. L. «Lead in gasoline.» Economic Analyses at EPA: Assessing Regulatory Impact. Ed. Richard D. Morgenstern. Vol. 49. Washington DC: Resources for the Future, 1997, pp. 49-86

(cit. on p. 19)

Nichols, K. M., Thompson, L. M., and Empie, H. J. «A review of NOx formation mechanisms in recovery furnaces.» Tappi Journal 76(1) (1993).

(cit. on p. 26)

Nikuradse, J. «Stromungsgesetze in rauhen Rohren.»VDI-Forschungsheft 361 (1933), p. 1

(cit. on p. 81) 
Ogen, Y. «Assessing nitrogen dioxide (NO2) levels as a contributing factor to coronavirus (COVID-19) fatality.» Science of the Total Environment 726 (2020). URL: https://doi.org/10.1016/j.scitotenv.2020.138605

(cit. on p. 25)

Partridge, W. P., Lewis, S. A., Ruth, M. J., Muntean, G. G., Smith, R. C., and Stang, J. H. «Resolving EGR Distribuion and Mixing.» SAE Technical Paper 2002-01-2882 (2002). URL: http://dx.doi.org/10.4271/2002-01-2882

(cit. on pp. $40,67,187$ )

Patterson, C. C. «Age of meteorites and the earth.» Geochimica et Cosmochimica Acta 10(4) (1956), pp. 230-237. URL: https://doi.org/10.1016/00167037(56)90036-9

(cit. on p. 16)

Patterson, C. C. «Contaminated and Natural Lead Environments of Man.» Archives of Environmental Health: An International Journal 11(3) (1965), pp. 344-360. URL: https://doi.org/10.1080/00039896.1965.10664229

(cit. on p. 17)

Payri, F., Luján, J. M., Climent, H., and Pla, B. «Effects on the intake charge distribution in HSDI engines.» SAE Technical Paper 2010-01-1119 (2010). URL: http://dx.doi.org/10.4271/2010-01-1119

(cit. on p. 40)

Pirkle, J. L., Brody, D. J., Gunter, E. W., Kramer, R. A., Paschal, D. C., Flegal, K. M., and Matte, T. D. «The Decline in Blood Lead Levels in the United States: The National Health and Nutrition Examination Surveys (NHANES).» Journal of the American Medical Association 272(4) (1994), pp. 284-291. DOI: 10.1001/jama.1994.03520040046039 (cit. on p. 19)

Pirkle, J. L., Schwartz, J., Landis, J. R., and Harlan, W. R. «The relationship between blood lead levels and blood pressure and its cardiovascular risk implications.» American Journal of Epidemiology 121(2) (1985), pp. 246258. URL: https://doi.org/10.1093/oxfordjournals.aje.a113995

(cit. on p. 19)

Richtmyer, R. D. «A survey of difference methods for non-steady fluid dynamics.» National Center for Atmospheric Research 63 (1963)

(cit. on p. 36) 
Richtmyer, R. D., and Morton, K. W. Difference methods for initial value problems. 2nd. New York: Wiley-Interscience, 1967 (cit. on p. 36)

Riemann, B., et al. Über die Fortpflanzung ebener Luftwellen von endlicher Schwingungsweite. Verlag der Dieterichschen Buchhandlung, 1860

(cit. on p. 35)

Roe, P. L. «Approximate Riemann solvers, parameter vectors, and difference schemes.» Journal of computational physics 43(2) (1981), pp. 357-372

(cit. on p. 37)

Sadashiva Prabhu, S., Nayak, N. S., Kapilan, N., and Hindasageri, V. «An experimental and numerical study on effects of exhaust gas temperature and flow rate on deposit formation in Urea-Selective Catalytic Reduction (SCR) system of modern automobiles.» Applied Thermal Engineering 111 (2017), pp. 1211-1231. URL: https://doi.org/10.1016/j.applthermaleng.2016.09.134 （cit. on p. 29)

Sapsford, S. M., Richards, V. C., Amlee, D. R., Morel, T., and Chappell, M. T. «Exhaust system evaluation and design by non-linear modeling.» $S A E$ Technical Paper 920686 (1992)

(cit. on p. 40)

Schofield, K. «An evaluation of kinetic rate data for reactions of neutrals of atmospheric interest.» Planetary and Space Science 15(4) (1967), pp. 643670. URL: https://doi.org/10.1016/0032-0633(67)90038-4（cit. on p. 26)

Serghides, T. K. «Estimate friction factor accurately.» Chemical Engineering 91(5) (1984), pp. 63-64

(cit. on p. 81)

Serrano, J. R., Climent, H., Piqueras, P., and García-Alfonso, O. «Analysis of shock capturing methods for chemical species transport in unsteady compressible flow.» Mathematical and Computer Modelling 57(7-8) (2013), pp. 1751-1759. DOI: 10.1016/j.mcm.2011.11.026 (cit. on p. 77)

Serrano, J. R., Piqueras, P., Navarro, R., Tarí, D., and Meano, C. M. «Development and verification of an in-flow water condensation model for 3D-CFD simulations of humid air streams mixing.» Computers and Fluids 167 (2018), pp. 158-165. DOI: 10.1016/j.compfluid.2018.02.032

(cit. on p. 32) 
Shen, K., Li, F., Zhang, Z., Sun, Y., and Yin, C. «Effects of LP and HP cooled EGR on performance and emissions in turbocharged GDI engine.» Applied Thermal Engineering 125 (2017), pp. 746-755. URL: https://doi.org/10.1016/j.applthermaleng.2017.07.064

(cit. on pp. 31, 187)

Siewert, R. M., Krieger, R. B., Huebler, M. S., Baruah, P. C., Khalighi, B., and Wesslau, M. «Modifying and Intake Manifold to Improve Cylinder-toCylinder EGR Distribution in a DI Diesel Engine Using Combined CFD and Engine Experiments.» SAE Technical Paper 2001-01-3685 (2001). URL: http://dx.doi.org/10.4271/2001-01-3685 (cit. on pp. 5, 40, 67, 187)

Smith, O. I. «Fundamentals of soot formation in flames with application to diesel engine particulate emissions.» Progress in Energy and Combustion Science 7(4) (1981), pp. 275-291. URL: https://doi.org/10.1016/03601285(81)90002-2

(cit. on p. 27)

Tatsumoto, M., and Patterson, C. C. «Concentrations of common lead in some Atlantic and Mediterranean waters and in snow.» Nature 199 (1963), pp. 350-352. URL: https://doi.org/10.1038/199350a0

(cit. on p. 17)

Tauzia, X., Maiboom, A., Karaky, H., and Chesse, P. «Experimental analysis of the influence of coolant and oil temperature on combustion and emissions in an automotive diesel engine.» International Journal of Engine Research 20(2) (2018), pp. 247-260. DOI: 10.1177/1468087417749391

(cit. on p. 32)

Thangaraja, J., and Kannan, C. «Effect of exhaust gas recirculation on advanced diésel combustion and alternate fuels - A review.» Applied Energy 180 (2016), pp. 169-184. URL: https://doi.org/10.1016/j.apenergy.2016.07.096

(cit. on p. 32)

Thomas, V. M. «The Elimination of Lead in Gasoline.» Annual Review of Energy and the Environment 20(1) (1995), pp. 301-324. DOI: 10.1146/annurev.eg.20.110195.001505 (cit. on p. 19) 
Toro, E. F., Spruce, M., and Speares, W. «Restoration of the contact surface in the HLL-Riemann solver.» Shock Waves 4(1) (1994), pp. 25-34

(cit. on p. 38)

Torregrosa, A. J., Broatch, A., Arnau, F. J., and Hernández, M. «A non-linear quasi-3D model with Flux-Corrected-Transport for engine gasexchange modelling.» Journal of Computational and Applied Mathematics 291 (2016), pp. 103-111. DOI: 10.1016/j.cam.2015.03.034

(cit. on pp. $39,78,187$ )

Tree, D. R., and Svensson, K. I. «Soot processes in compression ignition engines.» Progress in Energy and Combustion Science 33(3) (2007), pp. 272309. URL: https://doi.org/10.1016/j.pecs.2006.03.002

(cit. on pp. $5,27,28,125,126)$

Van Leer, B. «Towards the Ultimate Conservative Difference Scheme I. The Quest of Monotonicity.» Lecture Notes in Physics 18 (1973), pp. 163-168. DOI: $10.1007 / \mathrm{BFb} 0118673$

(cit. on p. 39)

Van Leer, B. «Towards the Ultimate Conservative Difference Scheme. II. Monotonicity and Conservation Combined in a Second-order Scheme.» Journal of Computational Physics 14(4) (1974), pp. 361-370. DOI: 10.1016/0021-9991(74)90019-9

(cit. on p. 39)

Van Roekel, C. A., Montgomery, D. T., Singh, J., and Olsen, D. B. «Evaluating dedicated exhaust gas recirculation on a stoichiometric industrial natural gas engine.» International Journal of Engine Research (2019). URL: https://doi.org/10.1177/1468087419864733 (cit. on p. 30)

Wallace, F., and Boxer, G. «Wave action in diffusers for exhaust-pipe systems, with special reference to the scavenging of two-stroke engines.» Proceedings of the type of Mechanical Engineers 170(1) (1956), pp. 1131-1156

(cit. on p. 35)

Wei, H., Zhu, T., Shu, G., Tan, L., and Wang, Y. «Gasoline engine exhaust gas recirculation - A review.» Applied Energy 99 (2012), pp. 534-544. URL: https://doi.org/10.1016/j.apenergy.2012.05.011

(cit. on p. 187) 
William, J., Dupont, A., Bazile, R., and Marchal, M. «Study of Geometrical Parameter Influence on Air/EGR Mixing.» SAE Technical Paper 2003-011796 (2003). URL: https://doi.org/10.4271/2003-01-1796 (cit. on p. 101)

Wilson, R. P., Muir, E. B., and Pellicciotti, F. A. «Emissions Study of A SingleCylinder Diesel Engine.» SAE Transactions 74012383 (1974), pp. 612-632

(cit. on p. 30)

Winterbone, D. E., and Pearson, R. J. Theory of engine manifold design: wave action methods for IC engines. Wiley-Blackwell, 2000

(cit. on pp. 35, 36, 37, 38, 39, 74)

Zamboni, G., and Capobianco, M. «Influence of high and low pressure and VGT control on in-cylinder pressure diagrams and rate of heat release in an automotive turbocharged diesel engine.» Applied Thermal Engineering 51(1-2) (2013), pp. 586-596. URL: https://doi.org/10.1016/j.applthermaleng.2012.09.040 (cit. on p. 31)

Zehnder, G. «Calculating gas flow in pressure-wave machines.» Brown Boveri Review 58(4-5) (1971), pp. 172-176

(cit. on p. 35)

Zeldovich, J. «The Oxidation of Nitrogen in Combustion and Explosions.» Acta Physiochimica U.R.S.S. 21(4) (1946), pp. 577-628

(cit. on p. 26)

Zheng M., Reader G.T., and Hawley J.G. «Diesel engine exhaust gas recirculation - a review on advanced and novel concepts.» Energy Conversion and Management 45 (2004), pp. 883-900

(cit. on p. 29) 